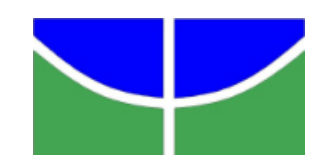

\author{
Universidade de Brasília - UnB \\ Instituto de Ciências Humanas - IH \\ Departamento de Serviço Social - SER \\ Programa de Pós-Graduação em Política Social - PPGPS
}

TESE DE DOUTORADO

ENTRE AS POLÍTICAS DE EDUCAÇÃO E DE ASSISTÊNCIA SOCIAL:

O caso da permanência escolar de alunos em acolhimento institucional

Anette Lobato Maia

Brasília, dezembro de 2014 
Anette Lobato Maia

\section{ENTRE AS POLÍTICAS DE EDUCAÇÃO E DE ASSISTÊNCIA SOCIAL: O caso da permanência escolar de alunos em acolhimento institucional}

Tese de doutorado apresentada ao Programa de Pós-Graduação em Política Social do Departamento de Serviço Social da Universidade de Brasília (UnB) como requisito parcial à obtenção do título de Doutora em Política Social.

Orientadora: Prof ${ }^{\mathrm{a}} \mathrm{Dr}^{\mathrm{a}}$ Maria Lúcia Pinto Leal 
Ficha catalográfica elaborada automaticamente, com os dados fornecidos pelo(a) autor(a)

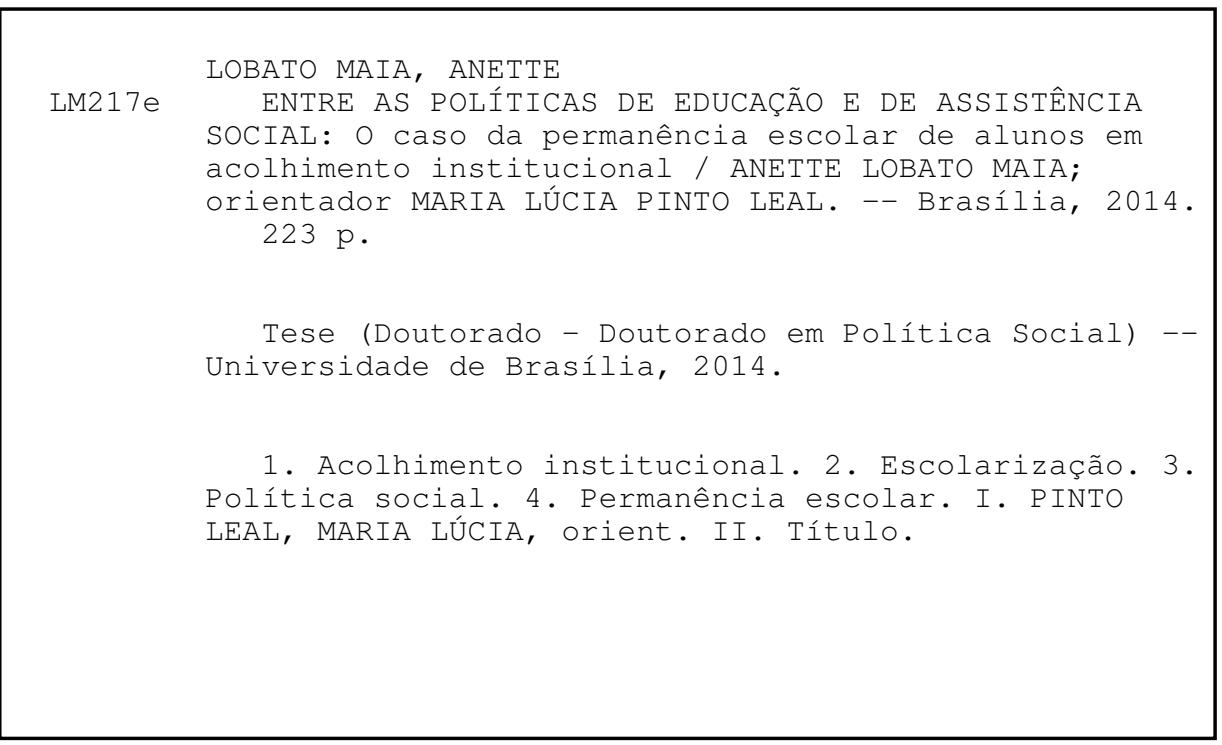


ANETTE LOBATO MAIA

\section{Entre as Políticas de Educação e de Assistência Social:}

$\mathrm{O}$ caso da permanência escolar de alunos em acolhimento institucional

Tese de doutorado apresentada ao Programa de Pós-Graduação em Política Social do Departamento de Serviço Social da Universidade de Brasília $(\mathrm{UnB})$ como requisito parcial à obtenção do título de Doutora em Política Social.

\section{BANCA EXAMINADORA}

Prof $^{\mathrm{a}}$ Dr $^{\mathrm{a}}$ Maria Lúcia Pinto Leal

(Orientadora - SER/UnB)

$\operatorname{Prof}^{\mathrm{a}} \mathrm{Dr}^{\mathrm{a}}$ Renata Maria Coimbra Libório

(FCT - UNESP/Presidente Prudente)

Prof $^{a}$ Dirce Mendes da Fonseca

(Uniceub/Distrito Federal)

$\operatorname{Prof}^{\mathrm{a}}$ Dr $^{\mathrm{a}}$ Angela Vieira Neves

(SER/UnB)

Prof $^{\mathrm{a}} \mathrm{Dr}^{\mathrm{a}}$ Silvia Cristina Yannoulas

(SER/UnB)

Prof. Dr. Carlos Alberto Ferreira Lima

(Suplente - CCA/FACE/UnB) 
À Sheila Amanda, minha ex-aluna.

(In Memoriam) 


\section{AGRADECIMENTOS}

Entendo o agradecimento como algo eterno, como o som das ondas do mar ecoando nas cavernas litorâneas. Dessa maneira, serei eternamente grata às pessoas, às instituições e às organizações a seguir, pois elas me constituíram na solidariedade, mas também no conflito, nas contradições advindas dos enfrentamentos. Assim, deixo registrada a minha gratidão:

Ao Sindicato dos Professores no Distrito Federal (Sinpro), onde a minha compreensão da luta de classes se alargou para além dos livros, graças a eventos como as campanhas salariais, as greves e as longas jornadas de formação política. Ali aprendi a importância dos coletivos. Foi no Sinpro que tudo começou.

À Secretaria de Estado de Educação do Distrito Federal, por ter possibilitado a presente construção pela via da concessão do afastamento remunerado para estudo.

À Universidade de Brasília e a seus combativos professores e professoras, pelo papel político que cumpriram em minha vida, especialmente os que ministraram as disciplinas do Programa de Pós-Graduação em Política Social. Mais do que fazer de mim uma graduada, mestra ou doutora, possibilitaram-me enxergar o mundo em suas profundas desigualdades, ajudando-me a construir o desejo por uma sociedade plena de justiça. No mesmo tom agradeço aos funcionários e funcionárias do referido programa, em particular a Domingas, que sempre foi solícita a cada um dos meus pedidos e demandas.

À minha orientadora $\operatorname{Dr}^{\mathrm{a}}$ Maria Lúcia Pinto Leal, pela enorme paciência comigo e com meus tempos de aprendizagem. E também pelo imenso papel que teve na minha construção como escritora em todos os momentos deste trabalho, sempre me animando frente aos desafios. Cada hora de dedicação a mim dispensada foi um crédito na minha capacidade.

À Escola Classe 708 Norte e às suas professoras, por me incentivarem a fazer o doutorado, apoiando-me quando eu me sentia frágil frente às dificuldades de análise da pesquisa.

Às amigas Marjorie Chaves, Camila Galetti e Sílvia Roncador pela leitura cuidadosa da tese e pela revisão que fizeram com tanta boa vontade.

A Lêda Gonçalves de Freitas pela eterna companhia, mesmo que à distância. 
Às servidoras e servidores da Sedest e da SEDF, que juntos estiveram comigo no GT Educação/Acolhimento e que muito contribuíram para que eu sentisse que a intersetorialidade é uma aspiração factível, mesmo com todas as tensões e conflitos que possa haver em sua investida.

A Dirce Barroso França pelos convites e debates propiciados em torno do acolhimento institucional.

A Luciana Vidal, por ter me apontado os caminhos para maior compreensão da política de Assistência Social em suas tensões e cotidiano.

A Samara Poliane, por ter partilhado de tantas reflexões importantes sobre acolhimento institucional nos momentos em que mais precisei.

Ao meu pai e à minha mãe, pelo respeito a mim e a minhas escolhas políticas.

A Maria Célia Orlato Selem, porque me acompanhou nos debates cotidianos sobre as políticas aqui abordadas, incentivando-me a cada dificuldade que surgia, trazendo poesia para os caminhos repletos de aridez.

À Prof ${ }^{\mathrm{a}} \operatorname{Dr}^{\mathrm{a}}$ Silvia Cristina Yannoulas, pelas oportunidades e por ter me apresentado autores e autoras que me ampliaram a visão do papel da educação para além das fronteiras nacionais, o que me trouxe uma perspectiva mais global dos problemas que atravessam a política de educação frente ao quadro neoliberal de nossos dias.

A cada uma das examinadoras que integraram a banca na ocasião da defesa da presente tese, pela maneira construtiva com que trouxeram as sugestões e as críticas ao meu trabalho acadêmico.

Por fim, agradeço ao conjunto da classe trabalhadora. Toda a riqueza do país sai de suas mãos. A presente tese não seria possível sem a riqueza por ela construída no campo ou na cidade. 
Há um menino

Há um moleque

Morando sempre no meu coração

Toda vez que o adulto balança

Ele vem pra me dar a mão

Há um passado no meu presente

Um sol bem quente lá no meu quintal

Toda vez que a bruxa me assombra

O menino me dá a mão

E me fala de coisas bonitas

Que eu acredito

Que não deixarão de existir

Amizade, palavra, respeito

Caráter, bondade, alegria e amor

Pois não posso

Não devo

Não quero

Viver como toda essa gente

Insiste em viver

E não posso aceitar sossegado

Qualquer sacanagem ser coisa normal

Bola de meia, bola de gude

O solidário não quer solidão

Toda vez que a tristeza me alcança

O menino me dá a mão

Há um menino

Há um moleque

Morando sempre no meu coração

Toda vez que o adulto fraqueja

Ele vem pra me dar a mão.

Milton Nascimento/Fernando Brant 


\section{RESUMO}

Este estudo teve como objetivo verificar como se materializa a permanência escolar de estudantes sob medida protetiva de acolhimento institucional, matriculados em cinco escolas da rede pública do Distrito Federal no período compreendido entre 2012 e 2013. Para alcançar tal intento, buscamos analisar, dentro das realidades investigadas, as ações promovidas por cinco unidades de ensino e duas unidades de acolhimento, no sentido de verificar como se dava a permanência escolar dos estudantes acolhidos institucionalmente, bem como os entraves para realizá-la. A investigação se deu por meio de uma abordagem exploratória, tornada possível por meio de entrevistas, e, de pesquisa documental. As entrevistas foram submetidas à análise de conteúdo. O método dialético cumpriu o papel de analisar a realidade em tela em suas múltiplas determinações. Verificamos, ao final do estudo, a inexistência e a necessidade de uma articulação entre escolas e unidades de acolhimento em prol da permanência escolar com qualidade das crianças matriculadas nos anos iniciais do ensino fundamental.

Palavras-chave: Acolhimento institucional. Escolarização. Política social. Permanência escolar. 


\section{ABSTRACT}

This study aimed to verify how materializes school students stay under protective measures of institutional care enrolled in five public schools of the Federal District in the period between 2012 and 2013. We were particularly interested in analyzing the work in five different schools and two institutional shelters, in order to observe the impact of sheltering over school attendance. The research was done through an exploratory approach, made possible through interviews, and documentary research. The interviews were subjected to content analysis. The dialectical method fulfilled the role of analyzing the reality in its multiple determinations. Toward the end of our research, we note the absence and the need for coordination between schools and shelters in behalf of school permanence with quality of children enrolled in the first years of elementary school.

Key words: Institutional shelter. Schooling. Social policy. Staying on at school. 
Este estudio tiene como objetivo verificar cómo se materializa la escolarización de estudiantes que se encuentran bajo las medidas de protección institucional, matriculados en cinco escuelas públicas del Distrito Federal-Brasil en el periodo comprendido entre los años 2012 y 2013. Para lograr este propósito, fueron analizadas, dentro de las realidades investigadas, las medidas adoptadas por cinco unidades de enseñanza y dos unidades de acogida, con el fin de verificar cómo se dio la permanencia en el sistema escolar de los estudiantes acogidos institucionalmente, así como los obstáculos para lograrlo. La investigación se realizó a través de un enfoque exploratorio, llevado a cabo a través de entrevistas y la investigación documental. Las entrevistas fueron sometidas a análisis de contenido. El método dialéctico cumplió la función de analizar la realidad en sus múltiples determinaciones. Observamos al final del estudio la ausencia y la necesidad de coordinación entre las unidades escolares y unidades de recepción tendientes a la permanencia escolar con calidad de los niños inscritos en los primeros años de la escuela primaria.

Palabras-clave: Permanencia en el sistema escolar. Escolarización. Política social. Acogimiento institucional. 


\section{LISTA DE SIGLAS}

ABEPSS - Associação Brasileira de Ensino e Pesquisa em Serviço Social

ANC - Assembleia Nacional Constituinte

BIA - Bloco Inicial de Alfabetização

BM - Banco Mundial

BNH - Banco Nacional da Habitação

BPC - Benefício de Prestação Continuada

CEB - Câmara de Educação Básica

$\mathrm{CF}$ - Constituição Federal

CFESS - Conselho Federal de Serviço Social

CGDH - Coordenadoria-Geral de Direitos Humanos

CNAS - Conselho Nacional de Assistência Social

CNE - Conselho Nacional de Educação

CNJ - Conselho Nacional de Justiça

CONANDA - Conselho Nacional dos Direitos da Criança

CRAS - Centro de Referência de Assistência Social

CRE - Coordenação Regional de Ensino

CREAS - Centro de Referência Especializado da Assistência Social

CT - Conselho Tutelar

DISA - Diretoria de Serviços de Acolhimento

DISOC - Diretoria de Estudos Sociais do Ipea

DPEDHUC - Diretoria de Políticas de Educação em Direitos Humanos e Cidadania

ECA - Estatuto da Criança e do Adolescente

EEAA - Equipe Especializada de Apoio à Aprendizagem

ESG - Escola Superior de Guerra

FEBEM - Fundação Estadual do Bem-Estar do Menor

FHC - Fernando Henrique Cardoso

FINEDUCA - Associação Nacional de Pesquisa e Financiamento da Educação

FIOCRUZ - Fundação Oswaldo Cruz

FMAI - Fundo Monetário Internacional

FNAS - Fundo Nacional de Assistência Social 
FUNABEM - Fundação Nacional para o Bem-Estar do Menor

IBGE - Instituto Brasileiro de Geografia e Estatística

IDEB - Índice de Desenvolvimento da Educação Básica

IPEA - Instituto de Pesquisa Econômica Aplicada

LDB - Lei de Diretrizes e Bases da Educação Nacional

LOAS - Lei Orgânica de Assistência Social

MDS - Ministério do Desenvolvimento Social e Combate à Fome

MEC - Ministério da Educação

NCEDH - Núcleo de Cidadania, Educação e Direitos Humanos da Coordenação de Educação em Direitos Humanos

ONG - Organização não Governamental

OSCIP - Organização da Sociedade Civil de Interesse Público

OTSACA - Orientações Técnicas para os Serviços de Acolhimento para Crianças e Adolescentes PBF - Programa Bolsa Família

PDAF - Programa de Descentralização Administrativa e Financeira

PDCFC - Plano Distrital de Promoção, Proteção e Defesa do Direito de Crianças e Adolescentes à Convivência Familiar e Comunitária

PDDE - Programa Dinheiro Direto na Escola

PDE - Plano de Desenvolvimento da Educação

PETI - Programa de Erradicação do Trabalho Infantil

PHC - Pedagogia Histórico-Crítica

PIA - Programa Individual de Acolhimento

PNAD - Pesquisa Nacional por Amostra de Domicílios

PNAIC - Plano Nacional de Alfabetização na Idade Certa

PNAS - Política Nacional de Assistência Social

PNCFC - Plano Nacional de Promoção, Proteção e Defesa do Direito de Crianças e Adolescentes à Convivência Familiar e Comunitária

PNDH3 - Programa Nacional de Direitos Humanos 3

PNE - Plano Nacional de Educação

PPP - Projeto Político-Pedagógico

PUA - Profissional da Unidade de Acolhimento

PUA1 - Profissional da Unidade de Acolhimento 1

PUA2 - Profissional da Unidade de Acolhimento 2 
PUC - Pontifícia Universidade Católica

RENAFOR - Rede Nacional de Formação Continuada de Profissionais na Educação Básica do Ministério da Educação

SAC - Serviço de Ação Continuada

SAM - Serviço de Assistência ao Menor

SGD - Sistema de Garantia de Direitos

SECADI - Secretaria de Educação Continuada, Alfabetização, Diversidade e Inclusão

SEDF - Secretaria de Estado de Educação do Distrito Federal

SEDEST - Secretaria de Estado de Desenvolvimento Social e Transferência de Renda

SNAS - Secretaria Nacional de Assistência Social

SUAS - Sistema Único de Assistência Social

SUBEB - Subsecretaria de Educação Básica

SUPLAV - Subsecretaria de Planejamento, Acompanhamento e Avaliação

TDAH - Transtorno do Déficit de Atenção com Hiperatividade

UA1 - Unidade de Acolhimento 1

UA2 - Unidade de Acolhimento 2 


\section{ÍNDICE DE QUADROS E GRÁFICOS}

\section{Quadros}

Quadro 1 - Identificação das professoras entrevistadas, suas escolas, instituições e alunos acolhidos

Quadro 2 - Profissionais demandados pelas professoras

\section{Gráficos (referentes à pesquisa com as docentes das escolas estudadas)}

Gráfico 1 - Como a docente tomou conhecimento sobre os artigos do ECA

Gráfico 2 - Momento em que as professoras se viam em situação-limite para resolução de conflitos

Gráfico 3 - A quem as docentes recorrem em momentos de dificuldade de aprendizagem e/ou quaisquer outras

Gráfico 4 - Limites encontrados pelas docentes quanto às unidades de acolhimento 116

Gráfico 5 - Adequação do plano de aula às necessidades específicas de alunos em acolhimento

Gráfico 6 - Alunos fora da faixa de idade/ano de escolaridade.

Gráfico 7 - Aprendizagem do aluno

Gráfico 8 - Características positivas apontadas para os alunos acolhidos pelas gestoras escolares

Gráfico 9 - Dificuldades ou problemas escolares dos alunos em geral apontados pelas escolas

Gráfico 10-O que a unidade de acolhimento proporciona para contribuir com a escolarização das crianças em acolhimento 
INTRODUÇÃO 18

CAPÍTULO 1 - A ESCOLHA DO MÉTODO 25

$1.1 \mathrm{O}$ percurso desenvolvido

CAPÍTULO 2 - A TRAJETÓRIA DO ACOLHIMENTO NO BRASIL: ENTRE A ASSISTÊNCIA E A EDUCAÇÃO

2.1 As políticas sociais no capitalismo e a realidade brasileira .40

2.2 Situando o Brasil histórica e economicamente no capitalismo internacional 42

2.3 A dinâmica das classes em luta na história brasileira. 44

2.4 A proteção social 52

2.5 Infâncias e as Políticas de Educação e Assistência Social em revista .56

2.5.1 A política educacional. .59

2.5.1.1 A educação durante o Período Colonial . 60

2.5.1.2 O Período Republicano 62

2.5.1.3 Ajustando o foco: agentes internos e externos da viabilização da permanência escolar com qualidade.

2.5.2 A Política de Assistência Social e o acolhimento de crianças e adolescentes .75

2.5.2.1 A história do acolhimento social 80

\section{CAPÍtUlo 3-AS ESCOLAS, AS UNIDADES DE ACOLHIMENTO E 0} DIREITO À PERMANÊNCIA ESCOLAR.

3.1 As entrevistas com docentes

3.1.1 Resultados obtidos com relação aos alunos das professoras entrevistadas.....

3.2 As entrevistas com gestoras

3.3 As entrevistas com coordenadoras. 
CAPÍtUlO 4-AS POLÍticas DISTRITAL E FEDERAL PARA A ESCOLARIZAÇÃO DOS ALUNOS ACOLHIDOS ......................... 167

4.1 A Portaria $\mathrm{n}^{\mathbf{0}}$ 46, de 7 de março de 2013: possibilidades e limites ............................ 169

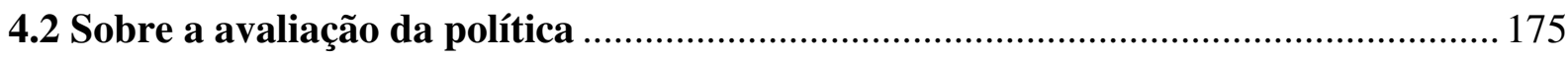

4.3 A divulgação da Portaria no 46, de 7 de março de 2013 ........................................... 177

4.4 O Governo Federal e a articulação intersetorial em torno da escolarização de

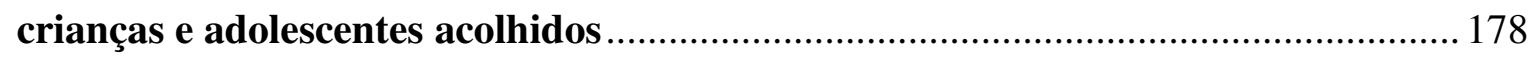

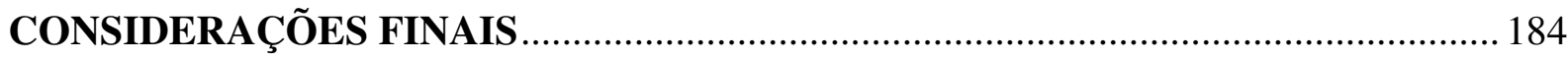

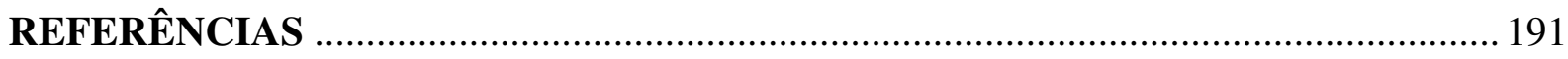

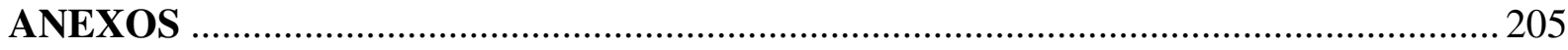

Anexo A - Formulário aplicado em entrevista às professoras ..................................... 206

Anexo B - Formulário aplicado em entrevista às professoras sobre os alunos

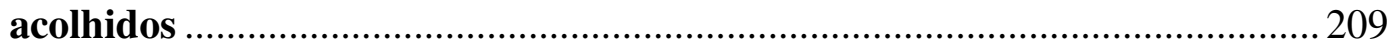

Anexo C - Formulário aplicado em entrevista às diretoras das escolas ....................... 212

Anexo D - Formulário aplicado em entrevista às coordenadoras das unidades de acolhimento

Anexo E - Formulário aplicado em entrevista à gestora distrital da Secretaria de Educação.

Anexo F - Formulário aplicado em entrevista à gestora distrital da Secretaria de Estado de Desenvolvimento Social e Transferência de Renda

Anexo G - Termo de Consentimento para profissionais da escola, do acolhimento, e para gestoras distritais da Assistência Social e Educação 
INTRODUÇÃO

A presente pesquisa busca conhecer como escolas e unidades de acolhimento cumprem seus papéis sociais com objetivo de garantir a permanência escolar de alunos em medida protetiva de acolhimento institucional nos anos iniciais ( $1^{\circ}$ ao $5^{\circ}$ ano) do ensino fundamental, particularmente após a homologação da Resolução Conjunta $\mathrm{n}^{\circ} 1$, de 18 de junho de 2009, que aprovou as Orientações Técnicas para Serviços de Acolhimento de Crianças e Adolescentes (Otsaca) pelo Conselho Nacional dos Direitos da Criança e do Adolescente (Conanda) e pelo Conselho Nacional de Assistência Social (CNAS).

A permanência escolar ${ }^{1}$ é aqui compreendida como uma categoria que transcende a mera frequência escolar diária, entendendo os anos iniciais do ensino fundamental como lugar e tempo de uma efetiva aprendizagem, em que se introduzem para as crianças os conceitos científicos, a fim de que consigam deslocar os conceitos do plano da ação para o plano do pensamento, conforme dispõe publicação do Ministério da Educação (BRASIL, 2007) ${ }^{2}$. É nos anos iniciais de escolarização que o desenvolvimento da capacidade de aprender deve ser trabalhado, tendo como meios básicos o pleno domínio da leitura, da escrita e do cálculo, como preconiza o inciso I do art. 32 da Lei de Diretrizes e Bases da Educação Nacional (LDB).

Faz-se importante frisar que, ao falar de permanência escolar, dada a histórica realidade das escolas públicas brasileiras, acabamos nos remetendo ao insucesso escolar, que por muitas vezes a inviabiliza. Dessa forma, ainda que o insucesso escolar ronde a vida da criança acolhida, precisamos buscar mediações que permitam construir situação de aprendizagem.

Tendo em vista que a permanência escolar é uma categoria central no estudo em curso, e em face da realidade de que a "desproporção entre produção acadêmica sobre evasão comparada à produção sobre permanência escolar é gigantesca" (CARMO, 2012, p. 2),

\footnotetext{
${ }^{1}$ Consta do art. 206 da Constituição Federal, em seu primeiro inciso, que o ensino será ministrado com base no seguinte princípio: igualdade de condições para o acesso e permanência na escola. Embora as condições para o exercício da segunda devam ser problematizadas dentro de uma sociedade com severas e históricas desigualdades como a brasileira, as quais serão tratadas ao longo da tese (mormente as sociais e raciais). Frente a uma realidade de atendimento quase que total do ensino fundamental, a permanência escolar que transcende à mera frequência, em nosso entendimento, coloca-se como um grande desafio, como pauta para movimentos sociais, na medida em que deve proporcionar, mais do que a estada do estudante em classe, a possibilidade de que efetue as objetivações de mais alto nível.

${ }^{2}$ Trata-se aqui da publicação Ensino Fundamental de Nove Anos: orientações para a inclusão da criança de seis anos de idade, editada em $2^{\mathrm{a}}$ edição em 2007.
} 
buscaremos então, diante de um quase vazio conceitual sobre permanência escolar, trazer aspectos encontrados em nossa pesquisa que abordam a estada das crianças em sala de aula, uma vez que não nos interessa somente saber se frequentam a escola com assiduidade ${ }^{3}$.

Cumpre dizer que a faixa de idade abarcadora dos anos iniciais do ensino fundamental, também chamada de $1^{\circ}$ segmento, está compreendida, em termos ideais, entre os seis e dez anos de idade, caso não haja distorção idade-ano de escolaridade. A pesquisa, no entanto, também presenciou alunos acolhidos entre os onze e os quatorze anos incompletos matriculados no citado segmento, tendo em vista as características não lineares de suas vidas estudantis, atravessadas por evasões, reprovações e/ou entradas tardias na escolarização. Em termos ideais, próprios de um país sem desigualdades tão profundas como o Brasil, somente crianças frequentariam o $1^{\circ}$ segmento do ensino fundamental, mas não raras vezes encontramos adolescentes nessas classes de escolarização. Adolescentes, em conformidade com o Estatuto da Criança e do Adolescente (ECA), são aqueles que se situam entre doze e dezoito anos.

O tema "Escolarização de alunos acolhidos institucionalmente" emergiu como preocupação a partir de diferentes estudos, levantamentos e pesquisas ${ }^{4}$ que apontam o baixo desempenho escolar de alunos em acolhimento institucional, questão bastante aventada no cotidiano das escolas públicas do Distrito Federal e que ainda carece de trabalhos científicos que contribuam para compreender em que medida a escola vem ou não se tornando uma presença mais contínua na vida dessas crianças e de que maneira isso se faz realidade. A escolha por um doutoramento em Política Social traduz o entendimento de que o tema suplanta uma abordagem restrita ao fenômeno educativo em suas interfaces com a Assistência Social, devendo ser percebido em um arco mais amplo de determinações, que dizem respeito

\footnotetext{
${ }^{3}$ Alguns trabalhos acadêmicos sinalizaram para uma necessidade de mais esforços no que se refere ao tema "permanência escolar" em múltiplas possibilidades de abordagem. Estão entre eles tanto os clássicos de Mello (1979) e Patto (1991) quanto produções mais recentes, também brasileiras, como as de Flach (2011) e Lenskij (2006).

${ }^{4}$ Entre eles podem ser mencionados: a) as pesquisas constitutivas da tese Crianças, Adolescentes e Transições Ecológicas: instituições de abrigo e família como contextos de desenvolvimentos, de Aline Siqueira (2009); b) o Levantamento Nacional dos Abrigos para Crianças e Adolescentes, conduzido pelo Ipea em parceria com o Conanda e publicado em 2004, sob o título de $O$ direito à convivência familiar e comunitária: os abrigos para crianças e adolescentes no Brasil; c) a pesquisa Depressão e desempenho escolar em crianças e adolescentes institucionalizados, sob a autoria de Débora Dalbosco Dellaglio e Claudio Hutz (2004); d) a pesquisa Por uma política de abrigos em defesa de direitos das crianças e dos adolescentes na cidade de São Paulo: motivos de demanda e qualidade de oferta de serviços de atenção à criança e adolescente sob medida de proteção "abrigo", realizada pela PUC/SP, Fundação Orsa e Associação dos Assistentes Sociais e Psicólogos do Tribunal de Justiça do Estado de São Paulo; e) os dados constitutivos do Levantamento Nacional das Crianças e Adolescentes em Serviços de Acolhimento, realizado pela Fiocruz, como uma iniciativa do Ministério do Desenvolvimento Social e Combate à Fome (MDS). A coleta de dados foi entre 2009 e 2010, tendo a pesquisa sido publicada na íntegra em 2013 sob o título Levantamento nacional das crianças e adolescentes em serviço de acolhimento (vide Referências).
} 
ao papel que o Estado desempenha, em diferentes conjunturas, junto à população (ou melhor, para a força de trabalho), por meio de políticas como Assistência Social e Educação em um contexto de classes sociais em permanente luta entre si.

Na direção da construção de um alicerce teórico que conduzisse de maneira adensada e politicamente compromissada a análise do nosso estudo, procedemos, por um lado, à leitura daqueles autores que adotam concepções críticas em relação ao estudo do Estado e das Políticas Públicas ${ }^{5}$ orientadas para a Educação $^{6}$ e a Assistência Social ${ }^{7}$, no sentido de compreendermos o contexto de crianças que demandam acesso à escolarização pública e estão sob medidas protetivas de acolhimento institucional; e, por outro, da legislação e dos planos ${ }^{8}$ que fundamentam as políticas voltadas para a garantia dos direitos subjetivos de crianças e adolescentes ao acesso e permanência na escola pública.

A construção da problemática da investigação esteve ancorada na experiência profissional da titular da tese em Política Social, como professora efetiva do ensino fundamental $^{9}$ da rede pública de ensino do Distrito Federal e das diferentes pesquisas e levantamentos provenientes de órgãos oficiais e de universidades, já citados anteriormente, que apontam a dificuldade que alunos acolhidos sofrem para se inserirem no mundo escolar, seus insucessos que sinalizam para uma permanência escolar complexa, contexto que trouxe uma série de inquietações, tanto a respeito do andamento da escolarização desses alunos quanto do entendimento daquilo que viria a ser a medida protetiva em si.

Nossa inserção nesse contexto, no plano imediato, indicava que a realidade de crianças acolhidas apresentava alguns indícios de que as medidas protetivas executadas entre a política de Educação e Assistência contraditoriamente não contribuíam para promovê-las no plano da escolarização. Podemos situar como indícios: distorções ano de escolaridade/idade, motivadas por evasões, repetências e entradas tardias no sistema; dificuldade no diálogo entre as escolas e as unidades de acolhimento, particularmente no sentido de propiciarem um melhor encaminhamento

\footnotetext{
${ }^{5}$ Behring e Boschetti (2010); Engels (1984); Iamamoto (2007, 2009); Pereira (2001, 2004, 2007, 2008, 2012).

${ }^{6}$ Bourdieu (1999); Duarte (2012); Frigotto e Ciavatta (2003); Lombardi (2010); Saes (2008); Saviani (2008).

${ }^{7}$ Iamamoto (2007, 2009); Boschetti e Teixeira (2004); Pereira (2007).

${ }^{8}$ Destacamos: a Constituição Federal de 1988; o Plano Nacional de Promoção, Proteção e Defesa do Direito de Crianças e Adolescentes à Convivência Familiar e Comunitária (2006); o Estatuto da Criança e do Adolescente (1990); o Plano Nacional de Educação (2001); o Programa Nacional de Direitos Humanos 3 (2010); a Lei Orgânica de Assistência Social (1993); o Plano Nacional de Educação (2001); a Lei de Diretrizes e Bases da Educação Nacional (1998).

${ }^{9} \mathrm{Na}$ qualidade de professora ou de coordenadora pedagógica, acumula mais de uma década de trabalho com alunos acolhidos, matriculados nos anos iniciais do ensino fundamental, na Coordenação Regional de Ensino do Plano Piloto - Brasília.
} 
às demandas que iam surgindo por causa desses alunos; e a reclamação feita pelas escolas de que a prestação de serviços por parte das unidades de acolhimento, conveniadas ou não, ficava a dever no cuidado relativo ao acompanhamento escolar dos estudantes acolhidos. Inclusive, devido à participação em cursos de formação, tais como os do Instituto Berço da Cidadania (IBC) - Oscip sediada em Brasília-DF -, já havíamos apreendido as queixas de profissionais do acolhimento quanto às professoras e suas conduções do processo ensino-aprendizagem.

Além desse conhecimento construído no cotidiano escolar, havíamos entrado em contato com pesquisas que confirmavam nossas preocupações quanto ao baixo rendimento dos alunos e seus percursos escolares não lineares (com reprovações ou evasões) dentro dos sistemas de ensino.

Tínhamos informação, proveniente de vivências pedagógicas, de algumas das limitações da escola para lidar com os conflitos advindos da permanência escolar de alunos que traziam narrativas de vida estranhas ao universo infantil idealizado pela mídia, pela publicidade e pela própria escola. Toda essa intrincada problemática com estudantes acolhidos gerava demandas institucionais, uma atenção docente mais detida sobre seu andamento escolar, requerendo uma disposição maior das gestões escolares e do acolhimento para lidarem conjuntamente com os conflitos e efetuarem as ações mitigadoras. Víamos professoras explicitarem a solidão da escola para enfrentar situações carregadas de lacunas, tais como o trato com crianças cuja aprendizagem deixava a desejar e o desengajamento do "abrigo" para com os alunos acolhidos.

Ao mesmo tempo, em fóruns em que unidades de acolhimento se encontravam, ouvíamos críticas substantivas ao elitismo das escolas, que não davam atenção aos alunos "que mais precisavam delas". Percebíamos, pelos relatos de profissionais do acolhimento e das escolas, que as crianças atendidas por ambos passavam por mediações que se antagonizavam, o que repercutia em diversas situações conflituosas. Podemos citar como exemplo o fato de a escola se indispor devido à criança levar brinquedos para as aulas, gerando queixas por parte da unidade de acolhimento ${ }^{10}$ com relação à atitude do estabelecimento de ensino.

Dessa forma, no plano das aparências, tínhamos um leque de informações embaralhadas por essa situação singular, que aparentemente se colocava para nós como um caos. O campo da singularidade não deixa que as essências apareçam. As coisas apresentam-se sem história no cotidiano, de maneira caótica. Dessa forma, foi necessário compreender as particularidades das

\footnotetext{
${ }^{10}$ Denominaremos as unidades de acolhimento de "abrigos" em alguns trechos da tese, seja por coerência histórica ou textual.
} 
Políticas de Educação e Assistência à luz das transformações operadas pelo Estado e a economia em âmbito global e suas repercussões no Brasil, na conjuntura estudada, para descortinar as armadilhas que forjam o presente objeto da pesquisa.

Nessa direção, questionamos como as escolas e unidades de acolhimento têm se munido de esforços para proporcionar às crianças uma permanência escolar satisfatória, de acordo com os direitos previstos na Constituição Federal, planos nacionais e políticas governamentais nesta conjuntura de ascensão neoliberal. Seguindo essa linha de raciocínio como norte da pesquisa, construímos as seguintes questões: a) A permanência escolar dos alunos acolhidos institucionalmente mobiliza escola e unidade de acolhimento? b) Haveria pontos de encontro entre as políticas sociais de Assistência Social e de Educação forjados por meio da intersetorialidade $^{11}$ ? c) Essas convergências entre as duas políticas serviriam ao debate em favor de uma permanência escolar mais profícua para os estudantes acolhidos? d) Quais esforços estariam sendo feitos com o intuito de garantir que alunos em medida protetiva de acolhimento permaneçam na escola, em conformidade com o que foi concebido pelo Estatuto da Criança e do Adolescente (ECA) e pelas Otsaca, em particular, em sua consonância com o Plano Nacional de Convivência Familiar e Comunitária (PNCFC), o qual lhes deu origem?

Duas outras questões que tangenciam as anteriores dizem respeito ao conhecimento das ações dos governos distrital - Secretaria de Estado de Educação do Distrito Federal (SEDF) e Secretaria de Estado de Desenvolvimento Social e Transferência de Renda (Sedest) - e federal - Ministério da Educação (MEC) e Ministério de Desenvolvimento Social e Combate à Fome (MDS) - em prol da permanência escolar de alunos acolhidos institucionalmente e do monitoramento sobre ela, sem perder de vista que o Distrito Federal, como um dos entes federados, pode apresentar particularidades em relação aos demais, tanto na política de Assistência Social quanto na de Educação ${ }^{12}$.

\footnotetext{
${ }^{11}$ Entendemos a intersetorialidade como um advento em que diferentes políticas sociais têm uma atuação articulada (ainda que contraditória), fugindo à vigente atomização, onde cada uma desempenha seus papéis de maneira desvinculada.

${ }^{12}$ No Brasil, a Constituição Federal prevê um sistema federativo mediante o regime de colaboração entre os entes federados. (BRASIL, 1988, art. 211). Ao Distrito Federal, autonomamente, entre outras obrigações constitucionais, cabe: elaborar e implementar seus próprios programas educacionais, além de estabelecer projeto político-pedagógico para as instituições que compõem seu sistema de ensino. No campo da Assistência Social, a Carta Magna, em seu art. 204, Inciso I, prevê uma perspectiva de descentralização político-administrativa, cabendo aos entes subnacionais (inclusive o Distrito Federal) a execução da política e a coordenação e regulação de normas à esfera nacional. Essa descentralização política é confirmada pela Lei Orgânica da Assistência Social (LOAS), no que concerne ao compartilhamento de responsabilidades entre os entes e estabelece competências mínimas para a União, estados, municípios e Distrito Federal.
} 
Este estudo teve como objetivo geral, portanto, verificar como se materializa a permanência escolar de alunos sob medida protetiva de acolhimento institucional, matriculados em cinco escolas da rede pública do Distrito Federal no período compreendido entre 2012 e $2013^{13}$. Os objetivos específicos tratam de analisar dentro das realidades investigadas: a) as ações promovidas por cinco unidades de ensino a fim de garantir a permanência escolar dos alunos acolhidos institucionalmente, bem como os entraves para alcançá-la; b) as ações promovidas por duas unidades de acolhimento para coadjuvar a permanência escolar dos alunos acolhidos institucionalmente, bem como os entraves para alcançá-la. $\mathrm{O}$ objeto da presente pesquisa incide nas práticas escolares e de acolhimento institucional que contribuem ou que dificultam a permanência escolar de alunos em medida protetiva de acolhimento no Distrito Federal.

A hipótese examinada por este estudo é que a escola e a unidade de acolhimento não constroem ações conjuntas para garantir a permanência escolar de alunos acolhidos institucionalmente, matriculados na rede pública de ensino. Como desdobramento desta hipótese, entendemos que a permanência escolar é algo mais que simples oposto de evasão. Dessa forma, ainda que o insucesso escolar ronde a vida da criança acolhida, contraditoriamente existem mediações que permitam construir situação de aprendizagem, mesmo em um difícil processo de democratização dessa demanda pela política de Educação e Assistência, em virtude dos ventos neoliberais responsáveis pela contrarreforma (BEHRING, 2003), ocorrida pós-1995, em relação ao estado constitucional de direito, promulgado em 1988 no Brasil.

$\mathrm{Na}$ perspectiva de que uma realidade complexa, multideterminada e historicamente carregada de contradições não pode ser entendida de maneira fragmentada, fizemos uso do método dialético a fim de ultrapassar a mera aparência dos fenômenos. O método remete ao emprego das quatro categorias teórico-metodológicas da dialética: historicidade, totalidade, contradição e mediação, com vistas à obtenção de respostas para além da aparência imediata do objeto em estudo.

Nessa direção, realizamos uma pesquisa qualitativa, buscando analisar e interpretar o conteúdo obtido nas entrevistas semiestruturadas por meio da análise de conteúdo. Também lançamos mão do levantamento bibliográfico e documental para adensar a discussão sobre os achados da pesquisa, buscando no método dialético uma compreensão não linear da realidade com a qual tomamos contato.

\footnotetext{
${ }^{13}$ As Otsaca foram publicadas em 2008 e a nossa pesquisa de campo em sua vigência ocorreu nos anos de 2012 e 2013.
} 
Este estudo, portanto, está estruturado em quatro capítulos. O primeiro aborda a escolha do método da pesquisa, entendendo que se trata de uma escolha ideológica. Nesse sentido, discorre sobre o método dialético e suas categorias: contradição, historicidade, totalidade e mediação. No referido capítulo, o percurso metodológico também é abordado.

O segundo capítulo tem como objetivo situar histórica, política e economicamente a realidade da escolarização vivida por crianças e adolescentes afastados da família e institucionalizados no Brasil. Com esse intuito, buscamos também apresentar autores com produção científica que nos contemplassem em nossas discussões e reflexões sobre os dados que coletamos: produções que fossem voltadas para o tema Política Social em espectro mais amplo; e, em âmbito mais restrito, para a Política Educacional, no tocante à escolarização no ensino fundamental, e para a Política de Assistência Social, mais especificamente no que se refere ao acolhimento institucional.

O terceiro capítulo apresenta a análise dos dados obtidos na pesquisa e que guardam correspondência com o primeiro objetivo da tese. Os dados foram obtidos por meio de entrevistas semiestruturadas com docentes e gestoras das cinco escolas pesquisadas e com coordenadoras de duas unidades de acolhimento.

O quarto capítulo diz respeito à resposta às nossas perguntas norteadoras, que versam sobre a relação entre unidade de acolhimento e escola; e aos possíveis encontros intersetoriais entre as Políticas Educacionais e de Assistência Social nas esferas dos governos distrital e federal no tocante à avaliação da permanência escolar das crianças acolhidas institucionalmente, em especial após as Otsaca. Destaca, nesse processo, a importância do GT Educação/Serviços de Acolhimento e da Portaria no 46, de 7 de março de 2013, no âmbito do Distrito Federal; e, em nível federal, a Nota Técnica $\mathrm{n}^{\circ} 23$ da Coordenadoria-Geral de Direitos Humanos (CGDH), Diretoria de Políticas de Educação em Direitos Humanos e Cidadania (DPEDHUC) e Secretaria de Educação Continuada, Alfabetização, Diversidade e Inclusão (Secadi/MEC).

Finalmente, em nossas considerações finais, situamos que escolas e unidades de acolhimento não se articulam para planejar ações com vistas a uma permanência escolar qualificada, ou seja, com aprendizagem. Por outro lado, verificamos que não existe nas escolas pesquisadas a evasão dos estudantes acolhidos. Além disso, identificamos um esforço bastante preliminar e inaugural de articulação entre secretarias distritais que respondem pela Assistência Social e Educação no sentido de se propiciar o acesso e a permanência escolar dos citados alunos, o que vem ocorrendo também em âmbito federal, por meio de ação conjunta entre MEC e MDS: esforços que vêm ocorrendo mesmo em uma conjuntura de flagrante presença de uma condução neoliberal dos governos distrital e federal. 


\section{CAPÍTULO 1}

\section{A ESCOLHA DO MÉTODO}

A escolha do método dialético é ideológica. Está sintonizada com os compromissos políticos que assumimos frente a um mundo extremamente desigual. Em face dessas considerações, escolhemos o marxismo como lente para construir nossa pesquisa e para interpretar os dados obtidos, tendo em vista que pesquisar temas relacionados às políticas sociais é fazer uma imersão em um campo de conhecimento construído dentro do próprio capitalismo: modo de produção que se caracteriza, entre outras possibilidades, por fazer da força de trabalho uma mercadoria por meio do assalariamento, o qual é concretizado pelo capitalista, que paga o salário ao detentor dessa força, ou seja, o trabalhador. As demandas dos trabalhadores por mais direitos do que somente os salários pressionavam o patronato, ao ponto de ele fazer concessões, que vieram a acontecer também na esfera do Estado, quando da construção de políticas sociais.

As políticas sociais, então, fazem parte de um conjunto de medidas de proteção próprias do sistema capitalista aos cidadãos que têm no Estado o importante executor. $\mathrm{O}$ Estado, não sendo neutro, sendo ente próprio e exclusivo das sociedades de classes, busca defender o interesse das classes proprietárias. No entanto, mediante as demandas e as pressões das classes que vivem do trabalho em defesa dos seus direitos, o Estado, por meio das frações de classe que o dirigem, é levado a negociar alguns ganhos, dentre eles as políticas sociais.

É importante situar, dessa forma, que mesmo sendo percebidas à primeira vista como instrumentos de cooptação da classe trabalhadora, como um "silenciador" momentâneo, as políticas sociais, por outro lado, "podem ser centrais na agenda de luta dos trabalhadores e no cotidiano de suas vidas, quando conseguem garantir ganhos para os trabalhadores e impor limites ao capital”. (BEHRING, 2006, p. 38). Pensar dialeticamente toda essa realidade, que não é fragmentada, tampouco caótica, é o desafio a que nos propomos, entendendo que "o pensamento dialético é obrigado a um paciente trabalho: é obrigado a identificar, com esforço, gradualmente, as contradições concretas e as mediações específicas que constituem o 'tecido' de cada totalidade, que dão 'vida' a cada totalidade”. (KONDER, 2007, p. 46). 
Hegel disse que as formas da dialética platônica vagaram baldias por 2 mil anos. Ele, em um esforço da razão, busca retomá-la na Modernidade. E, ao pensarmos a dialética a partir de Hegel, observamos que ela parte do princípio da identidade de opostos. Hegel enumera três unidades dentro da dialética: tese, antítese e síntese. A tese vem a ser o momento da afirmação; a antítese, por sua vez, o momento da negação da afirmação. Da tensão surgida dessa negação surge a síntese.

A síntese representa uma nova realidade marcada pela aparição da razão absoluta, da consciência de si; ou, o que dá no mesmo, da autoconsciência. A dialética é o movimento contraditório dentro de unidades, que a cada nova etapa nega e supera a etapa anterior, em um fluxo contínuo de superaçãorenovação. (SOARES DA COSTA, 2010, p. 63).

Importa perceber que tese, antítese e síntese não se articulam de maneira automática. “O momento final do processo que resulta na síntese é o menos amplo, é a fase final do primeiro ciclo dialético que eliminou as demais. Daí que, o que é importante, o movimento dialético representa o processo que vai do abstrato até o concreto". (Idem, p. 64).

Marx foi um leitor de Hegel, tendo se inspirado grandemente na obra desse idealista alemão. Uma das diferenças entre eles é que para Marx, entre tese e antítese, há uma mediação material. Não se trata de algo que se reduz ao plano reflexivo.

Daí que a solução na operação entre a contradição dos dois polos ocorre em Marx por meio da atividade prática do homem que supera a oposição entre sujeito e objeto, ou o que Marx vai conceituar como a práxis. A práxis é a atividade enérgica dos homens em face dos conflitos e contradições no âmbito da sociedade. (Idem, p. 70).

A dialética é o núcleo racional do materialismo de Marx e Engels, exposto em $A$ Ideologia Alemã. A oposição inscrita no sistema hegeliano entre a tese e a antítese, entre a afirmação e a negação, tem em Marx a mediação material, enquanto em Hegel é reflexiva, abstrata.

O núcleo de racionalidade do materialismo formulado por Marx e Engels é a dialética. Para Marx, entre a tese e a antítese há uma mediação material. No entanto, para Hegel ela está situada no plano da reflexão e da abstração. Quando nos remetemos à dialética marxista, a contradição significa a interpenetração de opostos dialéticos em sua unidade, da mesma maneira que os próprios opostos. "Opostos dialéticos são caracterizados por meio de duas especificidades: eles estão reciprocamente condicionando e reciprocamente excluindo". (MARQUITT, 1997, p. 58). 
Toda essa elaboração permite que investiguemos as políticas sociais com as lentes da contradição, que vem a ser a categoria que permite a observância de tendências ou aspectos opostos, que ocasionam a mudança qualitativa de estágios da realidade, a qual está sempre em movimento. Faz parte do propósito metodológico, também, enxergar as múltiplas determinações que permitem a existência do objeto em investigação. Busca-se, dessa forma, sair da abordagem monocausal. Qualquer fenômeno social em exame mostra-se primeiro pela aparência, o que obriga uma vigilância sob o caráter sedutor que a ela pode exercer à primeira vista. $\mathrm{O}$ primeiro contato com um fenômeno não dá conta de sua essência, tampouco responde por suas múltiplas causalidades em movimento. As respostas de uma pesquisa não podem partir só da visão imediata do fenômeno. O esforço de quem pesquisa pede um rigor que vai além do imediato. "Afinal, a existência do real e as formas fenomênicas da realidade são diferentes, e muitas vezes absolutamente contraditórias em relação à lógica interna do fenômeno, seu núcleo essencial”. (Idem, p. 39).

Dentro da mesma proposta do método dialético, há de se atentar, além da mencionada contradição, às categorias historicidade, totalidade e mediação. Viver em sociedade, em suas instituições e sob as práticas que delas decorrem é existir sob um legado carregado de história, de produção humana em coletividade. A historicidade possibilita enxergar essa construção superestrutural dentro das condições econômicas que a tornaram possível, tirando do reino da natureza, ou desnaturalizando, aquilo que é essencialmente histórico.

A totalidade permite, por outro lado, que acessemos o maior número de dados e aspectos de uma realidade, o que não significa que se apreenda todos, mas que se deve trabalhar com um número de elementos que satisfaça a tarefa investigativa. Na perspectiva marxiana, "a totalidade expressa o fato de que a realidade social é um conjunto articulado de partes. Cada uma dessas partes é, em si mesma, uma totalidade, de maior ou menor complexidade, mas jamais absolutamente simples”. (TONET, 2013, p. 96). A mediação, como categoria conectiva, torna possível que se percebam as ligações entre diferentes elementos que constituem a realidade em sua dinamicidade.

As categorias que utilizamos para nortear a nossa investigação e o desenvolvimento de nossa análise foram: acolhimento institucional, escolarização, política social e permanência escolar. Tal escolha decorreu do fato de a idade dos alunos acolhidos matriculados nas escolas pesquisadas estar na faixa de 6 a 10 anos (excetuando-se aqueles que estão fora da faixa idade/ano de escolarização). Decorre daí que eles têm o direito de frequentar com 
aprendizagem o ambiente escolar na perspectiva da ruptura com o menorismo e a tutela, com base na crença de que a infância não pode ser vivida asilarmente.

Um aporte metodológico dessa qualidade permite então quebrar a linearidade no exame das políticas sociais, bem como derruir ou abalar a perspectiva idealista, típica de alguns setores políticos, que afirmam que "basta querer para poder" acessar aqueles bens sociais a que temos direito, subestimando as longevas bases em que se ergue o poder dos capitalistas, inclusive ou principalmente dentro das esferas do Estado. No decorrer da elaboração dos instrumentos de pesquisa, a qual teve nas entrevistas a maior fonte de coleta de dados, também obtidos pelo exame de documentos, buscou-se formular perguntas que permitissem elaborar sobre o movimento real a partir e com as categorias singularidade, particularidade e universalidade. As três, conjuntamente, dão inteligibilidade à mediação.

A singularidade restringe-se ao campo institucional, visto ainda sem conexões, isolado e individualizado. A universalidade é o campo das leis universais, daquilo que está presente há tanto tempo nas sociedades de classes que aparece como natural: são as relações de produção, as relações sociais, o patriarcado, a relação que o Estado estabelece com o mercado e com a sociedade, as relações etnorraciais e todas as demais "leis" que possibilitam que a realidade no mundo capitalista seja da forma como se apresenta. A universalidade permite romper com a ideia de que os fenômenos são isolados, sem ligação entre si, fechados em suas singularidades. Por fim, a particularidade pode ser vista como um campo de intervenção. Nela o elemento singular se universaliza, sendo a recíproca verdadeira. É na esfera da particularidade que as intervenções planejadas e qualificadas podem ser realizadas com vistas a transformar uma realidade.

A escolha do método não é meramente instrumental, mas representa um confronto ou uma anuência com o saber e os poderes hegemônicos. A pesquisa nunca é neutra, mas somente algumas explicitam mais veementemente esse caráter. Afinal, a neutralidade científica busca camuflar interesses que estão no campo das classes, particularmente das frações dominantes. Fazer uma escolha teórica para interpretar os dados obtidos em uma pesquisa qualquer, mormente uma pesquisa de tese, é tornar evidente toda uma visão de mundo. Durante a construção do texto teórico, muitos estudos e teorias nos foram apresentados em sala de aula e em eventos de natureza científica, alguns com maior ou menor proximidade daquilo que pensávamos, ou seja, das lentes com as quais enxergamos o mundo.

Entendemos a Educação como direito de todos, assim como a Assistência Social, de maneira que consideramos fundamental o papel do Estado na oferta desses dois serviços 
públicos (e dos demais), devendo realizá-los com qualidade e com recursos compatíveis com as necessidades da população. Compreendemos o papel da ciência como fundamental para a intelecção dos óbices para uma vida plena de direitos nas sociedades capitalistas passadas e contemporâneas. Discordamos, nesse sentido, de que ela possa ser neutra. Nenhum pesquisador parte de uma estaca ideológica no nível zero. Cada ramo da pesquisa científica tem seus comprometimentos com essa ou aquela classe social, com esse ou aquele projeto de sociedade.

Assim, acreditamos que a pesquisa científica, verdadeiramente compromissada com toda a humanidade, pode melhorar as suas condições de existência, possibilitando que as pessoas se vejam livres de moléstias, mais protegidas de intempéries climáticas, demovidas de seus preconceitos e intolerâncias, afastadas de privações de toda ordem, por meio de políticas que permitam bem-estar sem causar danos irreparáveis ao meio ambiente. Por outro lado, não partilhamos de ideias liberais que responsabilizam os sujeitos por seu fracasso na escola, no mercado de trabalho ou em qualquer outro setor da vida em sociedade. Em uma sociedade de classes, as pessoas não estão no mesmo ponto de partida para alcançarem quaisquer objetivos, o que resulta em mais possibilidades de sucesso dos mais aquinhoados com os chamados capitais culturais, sociais e econômicos, para citar uma compreensão de viés bourdieusiano.

Por outro lado, acreditamos que a escola é um espaço de ensino, de partilha dos conhecimentos acumulados por docentes junto aos alunos. É local que foge à dinâmica da aprendizagem familiar. É um espaço formal de aquisição de conhecimento, local de debate teórico e científico entre seus profissionais com vistas a uma maior compreensão do processo pedagógico. Enxergamos na educação um forte papel na mudança da sociedade, mas um entre vários outros. Isso significa que a educação sozinha não dará as respostas para a construção de uma sociedade justa e igualitária. Se a base material não muda, as relações sociais permanecerão as mesmas. Como disse Paulo Freire, "Se a educação sozinha não transforma a sociedade, sem ela tampouco a sociedade muda”. (FREIRE, 2000, p. 67).

No campo da Assistência Social, adotamos um pensamento convergente: não a concebemos um ato de boa vontade, eivado de espontaneidade, de forte senso religioso ou de enlevado apelo moral, quando praticada por indivíduos. Em se tratando de governos, não a cremos como recurso utilizado somente para medidas emergenciais ou de extrema necessidade. Ao pensarmos a Assistência Social como processo complexo, vemo-la na sua racionalidade ética e cívica, posto que se trata tanto de um combate obrigatório por parte dos governos às iniquidades sociais quanto de um direito da cidadania. (PEREIRA, 2002). Da 
mesma forma que a Educação, não confiamos à Assistência Social o papel de sanar isoladamente as mazelas de um mundo capitalista, movido pela exploração da classe trabalhadora e pela luta de classes.

Ao esboçarmos as linhas genéricas de nosso pensamento quanto à Educação e à Assistência Social, buscamos a filosofia que nos sustenta para pensar o mundo em sua concentrada riqueza e em sua espraiada usurpação da força de trabalho. De igual modo, a mesma filosofia nos propiciará pensar as políticas sociais, aqui em exame, no tocante à permanência escolar de crianças em acolhimento institucional. No Brasil, dentre os vários autores em que nos detivemos para leituras mais aprofundadas, demos especial ênfase no que diz respeito à educação a Demerval Saviani, José Claudinei Lombardi e Newton Duarte. Os citados autores fazem de sua produção acadêmica uma contribuição para construir a Pedagogia Histórico-Crítica (PHC) no país. A escolha que fizemos pela PHC, no campo educacional, baseou-se em alguns aspectos, dentre eles: a) porque ela, ao mesmo tempo em que se contrapôs à corrente escolanovista, não se põe a favor do caráter não dialético das teorias críticoreprodutivistas, as quais não conseguem enxergar a escola para além de seu caráter reprodutor das relações sociais; b) porque foi forjada como necessidade para o país desde a última ditadura, oferecendo aos educadores brasileiros uma visão crítica da educação, nos seus limites e possibilidades dentro da ordem capitalista; c) porque nela a educação é compreendida como um elemento inserido nas relações sociais, devendo ser entendida à luz da história - professores e alunos são vistos como agentes sociais, atraídos a desenvolver uma prática social, a qual "não se centra na iniciativa do professor (pedagogia tradicional) ou na atividade do aluno (pedagogia nova), mas no encontro de seus diferentes níveis de compreensão da realidade por meio da prática social comum a ambos (BATISTA; LIMA, 2012, p. 7); d) por seu entendimento de que a educação é uma mediação no seio de várias práticas humanas; e) porque a educação é pensada como instrumento para a luta de classes, na medida em que pode ampliar a compreensão de mundo daqueles que a ela têm acesso; f) porque concebe que o trabalho educativo é o ato de produzir, direta e intencionalmente, em cada pessoa em particular, a humanidade que é produzida historicamente, de maneira coletiva, pelo conjunto dos seres humanos; e g) porque questiona o senso comum em sua visão de mundo fragmentária, sem coerência, desarticulada, desagregada, mecânica, passiva e simplista, buscando o oposto, o "desenvolvimento da consciência filosófica, unitária, coerente, articulada, explícita, original, intencional, ativa e cultivada”. (SAVIANI, 2009, p. 2). 
A soma de todos os elementos anteriormente citados eleva a educação escolar a um patamar mais realista de suas possibilidades dentro da ordem burguesa. Nem a superdimensiona como a grande responsável pela mudança do país, como o fazem os liberais, tampouco menospreza a sua capacidade de fazer que o alunado alcance as objetivações mais elevadas. (DUARTE, 1992). O investimento na escola pública não é ingênuo, portanto, mas amplamente sintonizado com as possibilidades colocadas para cada momento histórico.

No campo da Assistência Social, também buscamos autores que enxergam esta política contraditoriamente, que abordam a "questão social" como uma permanência dentro do capitalismo, não como uma novidade, posto que a luta dos trabalhadores tem tido o papel de torná-la visível desde o século XIX. Buscamos autoras do campo marxista como Potyara Pereira, Ivanete Boschetti, Elaine Behring e Marilda Iamamoto para fundamentar nossas análises, por entendermos que todas trabalham com as categorias do método dialético em suas produções, não incorrendo em percepções fragmentadas e atomizadas da realidade. Partilhando da concepção de que as diferentes políticas sociais precisam se articular entre si, abrimo-nos à possibilidade de pensar uma intersetorialidade entre Assistência Social e Educação, tendo em vista que acreditamos na necessidade de se somar esforços para o êxito da permanência escolar com aprendizagem. Importa acrescentar que não nos furtamos eventualmente de apresentar outros autores do mesmo campo (ou do campo ampliado), não necessariamente das mesmas políticas, para auxiliar-nos na nossa análise, a fim de que ela se tornasse mais minuciosa sem a perda do viés crítico.

\subsection{O percurso desenvolvido}

Como dito anteriormente, nossa pesquisa teve uma abordagem qualitativa, realizada por meio de entrevistas semiestruturadas nas escolas e nas unidades de acolhimento, sendo que aquelas constitutivas do Capítulo 3 passaram por uma Análise de Conteúdo, a fim de que extraíssemos dados significativos sobre a permanência escolar. Buscamos apresentar os dados

qualitativos obtidos com a utilização de gráficos, para maior compreensão dos leitores. É importante destacar que nem todos os campos do formulário de pesquisa semiestruturada foram preenchidos ou receberam resposta oral, mormente aqueles que pediam detalhes ou exemplos sobre determinado evento ou situação. 
O caminhar da pesquisa de campo, dividida em domínios local (escolas e unidades de acolhimento) e distrital (Sedest e SEDF), teve seu início, portanto, com as entrevistas semiestruturadas feitas à guisa de teste, o chamado pré-teste, nas escolas de Ceilândia. "Uma das características da entrevista semiestruturada é a utilização de um roteiro previamente elaborado". (MANZINI, 2004, p. 1). Somente nas entrevistas com os membros da escola tomamos como medida a adoção de uma pré-testagem, por ser a escola, entre as instituições estudadas, o espaço mais regulado em suas rotinas; e por ser mais diversa em termos da composição de trabalhadores, submetidos a uma divisão de trabalho mais complexa.

Era necessário que a entrevista fosse densa e célere, já que era realizada em horário de coordenação das docentes, mas era desígnio também que não se perdessem conteúdos importantes no momento de coleta. Bons instrumentos para concretizá-la eram fundamentais e passavam por uma pesquisa precursora, passível de aprimoramentos. Assim, escolhemos uma escola em Ceilândia, uma das cidades designadas para o campo, por motivos que veremos mais adiante, localidade que nos possibilitou entrevistar diferentes segmentos sobre a permanência escolar de crianças e adolescentes acolhidos institucionalmente, entre eles: gestoras, professoras, orientadora educacional ${ }^{14}$ e secretárias escolares.

A experiência na referida unidade de ensino possibilitou-nos uma avaliação quanto aos instrumentos que havíamos elaborado, a fim de realizar as entrevistas definitivas nas outras escolas, aquelas que efetivamente forneceriam material para a escrita da tese. O pré-teste fez com que: a) diminuíssemos o número de perguntas do formulário da entrevista inicialmente formulada para as docentes, longa e pouco sintonizada no aproveitamento escolar dos alunos. Nessa reformulação passaram a existir perguntas objetivas baseadas nas respostas mais incidentes do pré-teste e outras de teor subjetivo. E, juntamente à entrevista com as professoras (Anexo A), adotamos outro formulário menor (Anexo B), exclusivamente voltado para que elas fornecessem dados sobre a permanência escolar dos seus alunos em diferentes aspectos da vivência escolar; b) ratificássemos a necessidade de utilização do gravador durante o preenchimento das entrevistas semiestruturadas (perguntas objetivas e subjetivas). O mesmo procedimento foi feito com o instrumento, destinado a conhecer mais sobre os

${ }^{14}$ Conforme o Diário Oficial do Distrito Federal publicado em 5 de fevereiro de 2013, o "Especialista de Educação - Orientador Educacional integra-se ao trabalho pedagógico das unidades escolares e comunidade escolar colaborando na identificação, na prevenção e na transformação dos conflitos, acompanhando o processo de aprendizagem com vistas ao desenvolvimento integral do aluno. Para isto, tem como pressupostos o respeito à pluralidade, à liberdade de expressão, à orientação, à opinião, à democracia da participação e à valorização do aluno como ser integral", o que torna a especialidade afeta tanto a trabalhar com queixas relacionadas à disciplina quanto a encaminhamentos à própria EEAA. Sua distribuição por escola está na razão de 1 orientador para cada 100 a 499 alunos, de 2 para cada 500 a 999 alunos e de 3 para escolas com mais de 1.000 alunos. 
alunos acolhidos em sua cotidianidade estudantil; c) declinássemos do intuito de entrevistar secretários escolares, orientadores educacionais, pedagogos das equipes de avaliação da aprendizagem, entre outros, por motivos como a vacância dos cargos e licenciamentos, em diferentes escolas; d) construíssemos formulários de entrevistas para gestoras, semelhantes aos destinados às professoras, com perguntas objetivas e subjetivas.

É importante dizer que as entrevistas nas unidades de acolhimento, feitas com coordenadoras (formulário Anexo D) e as realizadas com gestoras das áreas distritais (formulários Anexos E e F) obedeceram a um procedimento mais simplificado: entrevistas semiestruturadas com gravação e sem a necessidade de que preenchessem formulários.

A escolha das escolas para a coleta de dados foi aleatória. Não existe um instrumento na SEDF que assegure em que escolas estão matriculadas as crianças e adolescentes em acolhimento institucional. Assim, ao visitarmos escolas próximas às unidades de acolhimento, buscávamos verificar se nelas havia alunos do $1^{\circ}$ ao $5^{\circ}$ ano acolhidos; e, em caso afirmativo, fazíamos o convite para as professoras e direção participarem da pesquisa com a concessão de entrevistas, mediante Termo de Consentimento Livre e Esclarecido (Anexo G). Não houve recusa de nenhuma escola encontrada nos moldes por nós desenhados para a investigação. Houve muita solicitude para o trabalho, por parte de gestoras e professoras, somente perturbada por imprevistos vividos por algumas frente à escala de entrevistas, o que ocasionou algumas defecções de docentes. As duas unidades de acolhimento entrevistadas foram escolhidas entre quatro, mais próximas das unidades de ensino e com alunos matriculados nelas. Apenas duas delas aceitaram participar da entrevista. Mesmo com ligações telefônicas após as visitas de aproximação das entidades acolhedoras, não obtivemos aceitação de todas para o citado fim, sem que quaisquer razões fossem explicitadas para nós.

O tempo para as entrevistas nas unidades escolares, sobretudo com as professoras, costumava ser exíguo. Em geral, uma hora do horário de coordenação pedagógica de terça ou quinta-feira era subtraída para esse fim, o que tornava a captação de toda e qualquer nuança de resposta muito importante. As docentes, mesmo assim, trouxeram importantes elementos que extrapolavam o teor das perguntas fechadas ou objetivas, o que tornou a gravação um importante instrumento para futuras análises, inclusive em se tratando de perguntas de caráter objetivo, pois mesmo nelas a entrevistada acabava por emitir comentários.

Era fundamental levantar conteúdos como as impressões, as convicções e as concepções de quem estava sendo entrevistado, acessando assim o caráter mais fluido da 
pesquisa semiestruturada, a fim de que obtivéssemos mais dados sobre sua prática cotidiana no trabalho, com vistas a entender a execução das políticas sociais abordadas na presente tese.

Algumas questões das entrevistas foram abandonadas logo no pré-teste, principalmente aquelas que indagavam a respeito da vida escolar de alunos acolhidos pelas vias do trabalho da secretaria da unidade de ensino. Não há informatização desses dados. A secretária teria de saber de memória os nomes dos alunos acolhidos que passaram pela escola e os anos de escolaridade frequentados, o que tornava o trabalho braçal e demorado, pois teria de se percorrer pasta por pasta do arquivo morto, correndo-se o risco de não encontrar os alunos pretendidos na forma como gostaríamos, ou seja, com razoável tempo de permanência na escola.

O nosso objetivo seria traçar um memorial de diferentes alunos, a partir de suas fichas de matrícula e de seus relatórios bimestrais, buscando dessa maneira verificar como ocorreu a escolarização de cada um, seus insucessos e avanços. O trabalho com ex-alunos possibilitaria uma comparação com os entraves e possíveis avanços na escolarização dos atuais, algo que não foi possível fazer, já que não há um dispositivo no Sistema de Matrículas da SEDF que afirme quais alunos estiveram ou estão sob medida protetiva de acolhimento, embora se possa detectar no mesmo sistema aqueles que recebem o Bolsa Família. Outra questão bastante importante é que nem todas as escolas pesquisadas, cinco no total, possuíam seus quadros funcionais completos, algo que viemos a perceber que se repetiria já no período de prétestagem.

Assim, todas as escolas tiveram suas gestoras e docentes entrevistadas, mas não houve a possibilidade de entrevistar os demais profissionais de outros cargos por inúmeras razões, inclusive a vacância. Ficaram fora da pesquisa, a partir do pré-teste, questões não passíveis de ser respondidas nas entrevistas, além de sujeitos de pesquisa, que de alguma maneira não dariam as respostas aos nossos objetivos de investigação, devido a um conjunto de limitações no arco de suas tarefas e em razão do aparato tecnológico de que dispunham, os quais não possibilitariam acessar dados biográficos e escolares ao longo do tempo.

Tínhamos a convicção de que os dados colhidos na gravação tinham uma importância substantiva, mas não queríamos conferir ao mundo empírico uma importância, própria dos modelos qualitativos, que resultasse na promoção "da análise da empiria fetichizada que caracteriza a sociedade capitalista”. (MARTINS, p. 9). Perseguimos, junto a esse enfoque, não proceder à fuga das análises das metanarrativas, não nos prendermos ao imediato, não nos 
furtarmos à compreensão mais essencial da realidade humana, realidade que, não sendo desordenada, tampouco caótica, pode ser apreendida no que tem de concreto.

Poderíamos até partir de uma situação em que a realidade parecesse caótica, aliás, efeito bastante comum quando se vai a campo. O esforço, após a fase mais árdua da coleta de dados, foi fazer com que a apreensão do fenomênico fosse passageira, rumasse pelo esforço da razão para o concreto pensado. Buscar entender como acontece a permanência escolar de crianças acolhidas, particularmente no primeiro segmento do ensino fundamental, é uma investida em uma atividade científica que guarda relação íntima com as políticas sociais de Assistência Social e Educação, mas que não se encerra nelas. Não poderíamos descartar ambas as políticas de outras determinações como as econômicas, políticas, históricas e culturais.

A categoria mediação, então, apareceu na análise de dados em toda a sua pujança, uma vez que tem papel central na "articulação entre as partes de uma totalidade complexa e é responsável pela possibilidade da passagem entre o imediato e o mediato". (PONTES, 1996, p. 3). A técnica utilizada para tratarmos as entrevistas degravadas foi a Análise de Conteúdo, baseando-nos nas leituras de Franco (2003) e Bardin (2009), de tal maneira que procedemos à leitura flutuante de todo o material, pergunta a pergunta, permitindo que emergissem as primeiras impressões sobre o que foi levantado a fim de que fossem anotadas. O corpus foi assim definido: os formulários da entrevista mais suas degravações foram a matéria-prima sobre a qual nos debruçamos, sendo que, a partir de ambos, fizemos os recortes dentro do vasto material para selecionar quais respostas e questões estavam mais intimamente ligadas ao nosso interesse. Não precisamos escolher uma amostra, pois atuamos em cima das entrevistas de 15 professoras, de 5 gestoras de escola e de 2 gestoras de unidades de acolhimento. Buscamos documentos mais homogêneos para o trato da investigação. Daí evitarmos entrevistar profissionais muito singulares, em cada instituição. Entrevistar a orientadora educacional, por exemplo, demandaria a compreensão específica de sua atuação na divisão do trabalho escolar, incorrendo no risco de em alguma escola o cargo estar vacante. Não usamos de hipóteses, particularmente, para fazer as análises de conteúdo, embora a hipótese da presente tese e seus objetivos específicos fossem um guia para a obtenção das respostas que queríamos dentro do corpus. Como sublinha Franco, "algumas análises podem ser efetuadas sem hipóteses preconcebidas". (p. 47). Os índices (tema em uma mensagem) foram coletados sistematicamente do corpus escolhido conforme a sua frequente incidência, seja porque havia repetição de expressões como "falta de acompanhamento da família", seja pela aparição de 
expressões com o mesmo significado, tal como "família ausente para os deveres de casa". Franco (2003, p. 49) explica que o indicador (da análise de dados) corresponde à "frequência observada do tema em questão". Por fim, analisamos esses indicadores por meio do aporte teórico escolhido.

Contabilizamos, como sujeitos pesquisados na política de educação: 5 gestoras de escola e 15 professoras, que por sua vez responderam sobre o desempenho de 20 alunos em acolhimento institucional. As professoras receberam nomes codificados no decorrer do trabalho para garantir o anonimato a elas prometido, tendo em vista a natureza da pesquisa, que envolve a citação de instituições, pessoas e situações às quais elas poderiam não querer que fossem identificadas. A primeira letra do código identificatório diz respeito à inicial da escola em que a profissional estava lotada. No âmbito da gestão distrital, entrevistamos uma gestora da SEDF e outra da Sedest. Nas unidades de acolhimento, as entrevistas foram realizadas com duas coordenadoras, codificadas como PUA1 e PUA2.

O quadro a seguir informa sobre as professoras entrevistadas, suas escolas e os alunos acolhidos de cada uma, bem como as instituições que os acolhem, além de informar sobre a existência ou não de convênio com a Sedest, a fim de receber recursos para a manutenção do serviço de acolhimento. 


\section{Quadro 1 - Identificação das professoras entrevistadas, suas escolas, instituições e alunos acolhidos}

\begin{tabular}{ccl}
\hline Professoras & Escolas & \multicolumn{1}{c}{ Aluno/Unidade de acolhimento } \\
\hline BX3* & B & BX3 (1)** UA2 (conveniado) \\
BX4 & B & BX4 (1) UA2 (não conveniado) \\
BX5 & B & BX5 (1) UA2 (não conveniado) \\
BX6 & B & BX6 (1) UA1 (conveniado) \\
BX8 & B & BX8 (1) UA2 (não conveniado) \\
BX9 & B & BX9 (1) UA1 (conveniado) \\
BX10 & B & BX10 (1) UA1 (conveniado) \\
BX11 & BX10 (2) UA1 (conveniado) \\
FX1 & B & BX11 (1) UA1 (conveniado) \\
FX2 & FX11 (2) UA2 (não conveniado) \\
FX3 & FX1 (1) LAR3 (não conveniado) \\
CX2 & F & FX1 (2) LAR 3 (não conveniado) \\
CX3 & FX2 (1) UA1 (conveniado) \\
DX2 & F & FX2 (2) UA1 (conveniado) \\
GY2 & CX2 (1) LAR 3 (não conveniado) \\
\hline
\end{tabular}

Elaboração própria com base em dados de pesquisa em 2013.

Nota 1: As escolas B, D e G estão situadas na Região Administrativa IX (RA-IX) - Ceilândia.

Nota 2: As escolas C e F estão situadas na Região Administrativa III (RA-III) - Taguatinga.

* Os nomes das professoras foram preservados, fazendo-se uso de códigos.

** Os nomes dos alunos foram preservados, fazendo-se uso de códigos.

Não entrevistamos crianças em nossa pesquisa, porque, no momento de elaboração do projeto, percebemos que colocaríamos as crianças em um campo bastante tenso, uma vez que trataríamos de questões como sucesso/insucesso escolar, indisciplina, impressões sobre a escola e a unidade de acolhimento, dentre outras: questões em que as duas instituições que são mais cotidianas aos alunos em situação de acolhimento estariam fortemente implicadas, sem que posteriormente pudéssemos acompanhar os impactos dos conteúdos trazidos por eles em suas próprias vidas.

Paralelamente à coleta de dados, a titular da tese também participou da constituição de um grupo de trabalho que envolveu duas secretarias distritais em torno da construção de ações e medidas que garantissem o direito ao acesso e permanência escolar de crianças e adolescentes acolhidos nas diferentes instituições do Distrito Federal, vindo também a participar da divulgação de uma portaria formulada pelo referido grupo, conforme relatado no Capítulo 4. 
As entrevistas realizadas em escolas e unidades de acolhimento foram colhidas em duas grandes regiões administrativas do Distrito Federal, Ceilândia e Taguatinga. Elas têm os maiores contingentes populacionais da unidade federativa. Com 450 mil habitantes, Ceilândia, aos 43 anos, emprega metade de sua população economicamente ativa, tem mais de 12 mil estabelecimentos comerciais e é responsável por um quarto do Imposto sobre Circulação de Mercadoria (ICMS) recolhido pelo Governo do Distrito Federal (GDF), mas nem por isso deixa de viver grandes contrastes em termos de desigualdade social.

Hoje, a cidade abriga duas das maiores favelas da América Latina, sendo o Sol Nascente maior que a Favela da Rocinha, emblemática na caraterização de um Rio de Janeiro muito desigual socialmente. Pôr do Sol e Sol Nascente têm 78.912 moradores. O número aponta o crescimento vertiginoso da população na região - que não conta sequer com sistema de saneamento básico, entre outros problemas, mais notadamente asfalto e urbanização. No Censo de 2010, do Instituto Brasileiro de Geografia e Estatística (IBGE), a população era de 56.483 pessoas. Importa sublinhar que Ceilândia é uma cidade oriunda da erradicação também de algumas favelas, que passaram a existir pela falta de moradia para quem trabalhou na construção de Brasília, fato que vem a mostrar que a propaganda de esperança para os mais pobres não se cumpriria para a maioria deles com a interiorização da Capital.

Taguatinga comporta a segunda maior população do Distrito Federal, com 361.063 moradores, tendo uma economia bastante diversificada, apesar de marcada pela segregação espacial histórica do Plano Piloto de Brasília. A região administrativa tem um Índice de Desenvolvimento Humano (IDH) considerado médio: 0,856 (medido no ano de 2000) e maior presença da infraestrutura proporcionada pelo Estado, se comparada a Ceilândia, com IDH de 0,784 (dado de 2000).

Enquanto Taguatinga se constituiu como um polo regional de comércio, Ceilândia não desenvolveu a mesma especialização. O próprio desenvolvimento do comércio possibilitou que Taguatinga sofresse um processo histórico mais marcado pela presença do poder público, embora oriunda também de lutas sociais dos trabalhadores, que quiseram se assentar na cidade depois de concluírem Brasília. "Cabe ressaltar que, no âmbito do poder público, Ceilândia é uma região que ainda carece de medidas eficazes na área pública. Logo, este lugar perde neste quesito do aparato público para Taguatinga”. (SANTOS, 2013, p. 1691). 
As duas cidades, Taguatinga e Ceilândia, sediam nove das dezoito unidades de acolhimento de todo o Distrito Federal, sendo apenas uma governamental. Entre as oito unidades não governamentais, apenas quatro têm convênio com a Sedest, recebendo recursos dela para seu funcionamento. Como já foi relatado, duas unidades de acolhimento, uma conveniada e outra não conveniada, tiveram suas profissionais entrevistadas, estas últimas profissionais escolhidas em razão de seu contato estreito com a escola quando em situações de conflito e de seu tempo maior de atuação dentro das unidades, as quais passam por uma grande rotatividade de profissionais. Ambas as unidades pertenciam à modalidade casa-lar, estando localizadas dentro de um mesmo terreno, na forma de um condomínio, o que significa que guardam características dos abrigos, ou seja, algumas atividades em horários conjuntos, mesmo para crianças que residem em unidades residenciais distintas. O total de escolas em Taguatinga e Ceilân dia é de 144 unidades, divididas entre a educação infantil, o ensino fundamental e médio. Foi nessas duas cidades tão importantes para o Distrito Federal - inscritas na história como contradições da construção de Brasília, que, ao receber trabalhadores para sua construção, não quis tê-los como seus moradores - que fizemos o campo de nossa pesquisa e sob as quais empreendemos as nossas análises centrais sobre o direito da criança acolhida à educação. 


\section{CAPÍTULO 2}

\section{A TRAJETÓRIA DO ACOLHIMENTO NO BRASIL: ENTRE A ASSISTÊNCIA E A EDUCAÇÃO}

A história nos julgará pela diferença que fizermos na vida de todos os dias das crianças. (Nelson Mandela)

Não é o sofrimento das crianças que se torna revoltante em si mesmo, mas sim que nada justifica tal sofrimento. (Albert Camus)

\subsection{As políticas sociais no capitalismo e a realidade brasileira}

Ao começarmos um trabalho acadêmico em torno da temática Política Social, não podemos prescindir de certo grau de detalhamento histórico sobre o país em que a análise se pautará. Dessa maneira, a história figura-se como elemento fundamental ao método e aparece como esteio para que teçamos análises e argumentações. Quase o mesmo podemos dizer quanto aos aspectos econômicos, embora funcionem menos como um apoio e mais como uma base na qual se ergue toda a realidade que buscamos conhecer. Dessa maneira, o presente capítulo buscará debater conceitos, momentos histórico-econômicos e as políticas sociais de Assistência Social e Educação deles decorrentes. É sobre esse alicerce que daremos continuidade aos demais capítulos.

Em caráter introdutório, faz-se importante mostrar que partilhamos da concepção de que a política social é o "produto da relação dialeticamente contraditória entre estrutura e história e, portanto, de relações - simultaneamente antagônicas e recíprocas - entre capital x trabalho, Estado x sociedade e princípios da liberdade e da igualdade que regem os direitos de cidadania”. (PEREIRA, 2008, p. 166). Nesse sentido a política social não é linear, não pode ser vista como produto em favor exclusivo de uma classe, nem valorada como somente positiva ou negativa. Como destaca Pereira (2008, p. 173), a política social afigura-se como política pública, na medida em que compromete o Estado, forças políticas e agentes sociais, constituindo-se uma espécie do gênero política pública. 
Reportando-nos ao passado, é relevante dizer que, apesar de todo o conjunto de lutas sociais do início do Brasil Republicano até nossos dias, elas não resultaram em um Estado de Bem-Estar $^{15}$ como aquele próprio aos países social-democratas sob o Welfare State, onde, especialmente entre o fim da II Guerra Mundial e o início dos anos 1970, a classe trabalhadora que compunha suas populações teve patamares de vida nunca antes vistos no capitalismo, período em que, como relata Pereira (2008), cada país tinha o compromisso de garantir, além do pleno emprego, o estabelecimento de um mínimo de proteção social para toda a população, havendo também a asseguração da cobertura universal de serviços como saúde e educação. Estava em andamento uma mudança que concebia a cidadania como um dever do Estado e como direito do cidadão.

Duas doutrinas, fundamentalmente, orientavam tais mudanças articuladas entre si:

Uma, econômica, concebida pelo economista inglês John Maynard Keynes (denominada doutrina keynesiana), e outra social, liderada pelo estrategista político, também inglês, William Beveridge (criador do popular Sistema de Seguridade Social do Segundo Pós-Guerra). (PEREIRA, 2010, p. 2).

Para que tal intento, denominado pacto keynesiano, lograsse êxito, houve múltiplas determinações históricas. Entre elas estão a memória das privações da guerra, o medo das classes capitalistas de assistirem à Europa ser tragada pelo comunismo ou mesmo pelo fascismo. Somado a esses fatores, o liberalismo clássico não havia trazido experiências favoráveis para o conjunto das classes trabalhadoras desde o século XIX.

Os Estados de Bem-Estar foram alvo de inúmeros estudos no tocante à materialização da proteção de seus cidadãos, dentro dos quais estabeleceram-se tipologias, sobre as quais nos deteremos mais adiante. Antecipamos que a proteção social no país é considerada uma mescla de distintos tipos de intervenção.

\footnotetext{
${ }^{15} \mathrm{O}$ termo "bem-estar" é aplicado a uma gama de experiências muito distintas em termos de intervenção estatal. Importante a explicação de Boschetti (2003) para entendermos as distinções: a primeira distinção que nos parece importante de ser aprofundada é entre os conceitos Welfare State (anglo-saxão), Etat-Providence (francês) e Sozialstaat (alemão) e sua distinção do termo "seguridade social". São conceitos elaborados em cada nação para designar determinadas formas de intervenção estatal na área social e econômica e muitas vezes incorporados ou traduzidos sem o devido cuidado na sua precisão e explicitação. É comum encontrar na literatura anglo-saxônica a utilização do termo Welfare State para designar genericamente os países que implementaram políticas sociais sob a orientação fordista-keynesiana, ainda que os próprios não se caracterizem como tal, como é o caso da França e da Alemanha. (BOSCHETTI, 2003, p. 61). Diante de tantas denominações, quando aqui mencionamos "bem-estar" na presente citação, estávamos nos referindo a um modelo de bem-estar que estivesse pelo menos dentro de um padrão social democrata, padrão que juntamente ao socialista teria inspirado, por exemplo, a seguridade social brasileira.
} 
Isso porque, no exame das características da proteção social oferecida no Brasil, há os seguintes componentes:

Intervenções públicas tópicas e seletivas - próprias dos modelos liberais -; adoção de medidas autoritárias e desmobilizadoras dos conflitos sociais típicas dos modelos conservadores -; e ainda estabelecimento de esquemas universais e não contributivos de distribuição de benefícios e serviços característicos dos regimes social-democratas. E tudo isso foi mesclado às práticas clientelistas, populistas, paternalistas e de patronagem política, de larga tradição no país. (PEREIRA, 2000, p. 127).

Diante desse mix de intervenções, não assistimos na história brasileira a um puro liberalismo $^{16}$, entendido como aquele que defende as funções do Estado prioritariamente volvidas para a garantia dos direitos individuais, sem que realize a interferência nas esferas da vida pública e, de modo particular, na esfera econômica de cada sociedade. Tampouco podemos dizer que o Estado de Bem-Estar aos moldes do pacto keynesiano aqui tivesse chance de ser realizado. Não houve condições materiais para isso, embora alguns avanços tenham ocorrido pela ação combativa dos trabalhadores, especialmente em momentos de governos autoritários e repressores, quando paradoxalmente a política social no país teve maior expansão. Mais contemporaneamente, vivemos a disseminação das teses neoliberais, resposta às crises cíclicas que o capitalismo tem vivenciado, em particular as ocorridas após 1970.

A seguir, buscaremos mostrar a entrada subalterna do Brasil no contexto das economias coloniais, para que se permita assim o entendimento de quão distantes as classes dirigentes estiveram das massas trabalhadoras e quanto isso repercutia e vem repercutindo, seja com maior ou menor intensidade, no baixo acesso delas às políticas sociais que lhes garantam, entre outras possibilidades, uma educação de qualidade, objeto de interesse deste trabalho.

\subsection{Situando o Brasil histórica e economicamente no capitalismo internacional}

No decorrer do processo de expansão capitalista, Paulani (2013) afirma que o Brasil viveu cinco grandes momentos. São eles: 1) Acumulação Primitiva: o Brasil é visto como reserva patrimonial, base onde opera força de trabalho compulsória; e como fonte de extração e fornecimento de metais preciosos e matérias-primas. O país constituiu-se em local de espoliação,

\footnotetext{
${ }^{16}$ Como inspiração para o pensamento liberal, fica a máxima de Adam Smith: "deixe-se a cada qual, enquanto não violar as leis da justiça, perfeita liberdade de ir em busca de seu próprio interesse, a seu próprio modo, e faça com que tanto seu trabalho como seu capital concorram com os de qualquer outra pessoa ou categoria de pessoas". (SMITH, 2003, p. 47).
} 
expediente típico da fase de acumulação primitiva. Ele é, no alvorecer do século XVI, uma parte subordinada de um capitalismo em consolidação. 2) Consolidação do modo de produção capitalista: os bens eram produzidos na Colônia em movimentos cíclicos assentados, possuíam baixo valor agregado e eram produtos qualitativamente distintos. Em um período que abrange desde a época do exclusivo metropolitano, terminando no início do século XX, o Brasil propulsiona a acumulação no Centro, conforme interesses internacionais do capitalismo. A produção de manufatura na Europa estava assegurada pela nossa inserção "por baixo", no modo de produção em curso. 3) Indícios de crise de sobreacumulação no Centro: o período anterior vigorou até 1930. A partir daí até 1950, o país deu indícios de construir sua trajetória independente e soberana rumo à industrialização. No entanto, o capital do Centro, vivendo uma fase de sobreacumulação, precisou deslocar-se para o Brasil para valorizar-se. Aqui poderia se expandir como não teria sido possível na Europa. Contou para isso com a fragilidade das elites brasileiras em seus propósitos de emancipação. Os imperativos de fora passam a ser dominantes. 4) Afirmação da crise de sobreacumulação (primeira etapa da financeirização ${ }^{17}$ ): o recurso ao uso da poupança externa pelo país começa na fase anterior. Manter as indústrias estrangeiras foi bastante dispendioso. A acumulação ocorria sob a lógica inconteste da valorização financeira. O processo é determinado internamente, porém o comando é feito pelo capital de fora. O Brasil de então era uma economia periférica já industrializada, vindo a ser atingida pela financeirização veloz do capitalismo em âmbito mundial. 5) Amadurecimento da financeirização (segunda etapa da financeirização): o ascendente movimento de financeirização transforma o país em plataforma internacional de valorização financeira. Inaugura-se nos anos 1990 a quinta e atual fase da história da inserção da economia brasileira no processo mundial de acumulação. O Brasil cambia de sua condição passiva para uma condição ativa, todavia subordinada, de inserção no capitalismo financeirizado.

Todos os momentos descritos servem para ilustrar quanto as frações de classe proprietárias, ao longo da história brasileira, se esquivaram de um projeto de autonomia econômica para o país, construindo um distanciamento dos setores populares e de suas demandas quase sempre resultantes de um constante espólio. No entanto, é preciso ratificar que o acontecido não decide o porvir. Florestan Fernandes, nesse sentido, afirmou que "o importante e decisivo não está no passado, remoto ou recente, mas nas forças em confronto histórico, em luta pelo controle do Estado e do alcance da mudança social”. (FERNANDES,

\footnotetext{
${ }^{17}$ Vem a ser um processo mais recente de geração de valor, não material, que é possível graças ao deslocamento do processo de produção manufatureiro. Está relacionado com a crise do capitalismo no início da década de 1970.
} 
1974, p. 209-210). Afirmativa que foge a um determinismo, colocando para as classes trabalhadoras uma real possibilidade de mudança.

\subsection{A dinâmica das classes em luta na história brasileira}

O presente tópico busca situar os interesses de classe, bem como de suas frações, no transcurso de nossa história, não a título de esgotar o assunto, mas de permitir o entendimento de como as classes foram se colocando na construção do Brasil até os dias mais recentes, pensando também nas "heranças" que deixaram para o presente momento. Para dar início a qualquer análise sobre o caráter dependente do Brasil, em cenário internacional, é necessário frisar que as burguesias locais agem como parceiras daquelas que são hegemônicas. Ou seja, as forças das quais fala Fernandes (1974) são internacionais também. Portanto, além de entreguistas, as forças nacionais postam-se como agentes consorciadas às hegemônicas em um desenvolvimento desigual. Situação que se repete no capitalismo, que "opera como um sistema que desenvolve e integra ou exclui de maneira desigual as economias mais dinâmicas e as economias capitalistas dependentes". (CARDOSO, 2006, p. 35). Não se deve, assim, encarar o capitalismo dependente como anomalia, como um capitalismo defeituoso, por mais nefasto que ele possa ser às classes oprimidas. A “dependência” é uma modalidade subordinada de inserção no capitalismo, ou, como explicita Fernandes, é uma "forma periférica e dependente do capitalismo monopolista (o que associa inexorável e inextricavelmente as formas 'nacionais' e 'estrangeiras' do capital financeiro)”. (FERNANDES, 1950, p. 50).

Cabe ressaltar que inúmeras foram as insurgências populares nesse quadro de dependência reiterada no decorrer da história brasileira. No entanto, mesmo as importantes insurgências coloniais não consolidaram uma Independência vinda pela ação dos de baixo. O que ocorreu no "Sete de Setembro de 1822" foi uma reacomodação das forças das classes dominantes, uma "revolução" evanescida, o que permite dizer que o país foi antes Estado e depois nação, fato que garantiu a unificação do Brasil, mas que repercutiu negativamente na construção de agendas democráticas para o próprio país em tenra idade. Sobre isso Coutinho (2006) afirma que:

Tivemos, desde o início de nossa formação histórica, uma classe dominante que nada tinha a ver com o povo, que não era expressão de movimentos populares, mas que foi imposta ao povo de cima para baixo ou mesmo de fora para dentro e, portanto, não possuía uma efetiva identificação com as questões populares, com as questões nacionais. (COUTINHO, 2006, p. 176). 
Assim, não se assiste a uma ruptura forte e radical com o passado colonial. Ao lado das forças políticas que permitiram a Independência, havia aquelas de cunho conservador, sem envergadura moral e consistência política para o avanço que permitiria construir um Brasil livre das amarras de um passado escravocrata, usurpador do povo e de suas riquezas. $\mathrm{O}$ pensamento liberal que permitiu a Independência não tinha enraizamento suficientemente profundo a ponto de permitir que as massas obtivessem as mesmas conquistas que as elites. Na compreensão de Behring e Boschetti (2010), também influenciada pela obra de Florestan Fernandes, as elites nativas captam o liberalismo por uma lente singular:

A equidade configura-se como emancipação das classes dominantes e
realização de um certo status desfrutado por elas, ou seja, sem incorporação
das massas; na visão de soberania, supõe-se que há uma interdependência
vantajosa entre as nações, numa perspectiva passiva e complacente na
relação com o capital internacional; o Estado é visto como meio de
internalizar os centros de decisão política e de institucionalizar o predomínio
das elites nativas dominantes, numa forte confusão entre público e privado.
(BEHRING; BOSCHETTI, 2010, p. 73).

É então em um clima de liberalismo de baixo alcance, desprovido de uma substância que desse mais horizonte do que apenas promover a sua elite colonial a uma situação mais digna e autônoma, que o Brasil se fez "independente" em 1822; entretanto, erguido sob a mesma estrutura colonial com base latifundiária e escravista. Fernandes (1974) chega a afirmar que a Independência foi solapada como processo revolucionário, em razão da pujante presença de influências histórico-sociais, que não permitiam a ruptura com o passado. Em nenhum momento ele desmerece o papel do liberalismo, mesmo assumindo suas limitações no cenário brasileiro. Foi o pensamento liberal que permitiu aos senhores rurais pensar mais autonomamente, sem nexos com o estatuto colonial que lhes aprisionava as aspirações.

A revolução burguesa no Brasil "nasce marcada com o selo do mundo rural, sendo a classe dos proprietários de terra um dos seus protagonistas". (IAMAMOTO, 2008, p. 136). Em terras brasileiras, foi a agricultura que propiciou a acumulação de capital que serviu mais adiante ao comércio e à indústria; e, importa ratificar, foi a sociabilidade hierárquica do mundo rural que serviu de base para aqueles que no futuro abandonaram a terra pela cidade, imigrantes ou não, bem ou mal-sucedidos. Se, do ponto de vista da economia, a elite portadora do pensamento liberal local se investiu de um ideal de competitividade, por outro lado, repelia “a igualdade jurídico-política, tal como proclamada nas cartas constitucionais". (Idem). É uma burguesia que não abre mão de um tradicional mandonismo oligárquico, embora fortemente influenciada por discursos da livre concorrência. 
Dessa forma, grandes extensões de terra mantiveram-se nas mãos de poucos afortunados, o que se configura como um padrão brasileiro em seus distintos momentos históricos, questão decisiva na constituição do Estado e das lutas sociais travadas no campo. O que não significa que o grande capital estivesse tendo menos presença frente ao Estado, porque capital e renda da terra tendem a se fundir numa mesma figura no país. Importante situar que, no decorrer de nossa história republicana, as composições políticas que possibilitaram a existência dos blocos de poder subtraíram a possibilidade da presença dos trabalhadores rurais. Dessa maneira, eles estiveram excluídos até mesmo dos pactos populistas. Assim, as composições do bloco de poder estavam constituídas por alianças que mantiveram a presença forte da velha oligarquia fundiária. É necessário sublinhar que o ideal liberal, expresso na Constituição de 1824, conviveu com a escravidão e com a prática do favor, em um inusitado amálgama. Como afirma Iamamoto, “aqui os princípios liberais não se forjaram na luta da burguesia contra a aristocracia e a realeza e não evoluíram em função da revolução industrial. A industrialização no Brasil só se consolida tardiamente no Brasil no século XX”. (IAMAMOTO, 2008, p. 138).

Os limites do pensamento liberal no Brasil foram dados pela escravidão, pela sobrevivência de uma produção estruturalmente arcaica e por uma inserção dependente nos quadros do capitalismo internacional. Não houve uma disputa interna entre burguesia, aristocracia e realeza, conforme vimos no continente europeu no decorrer da modernidade nos séculos XVIII e XIX. Ainda que antes da Independência tenha havido uma insatisfação das elites contra o pacto colonial, a manutenção da escravidão, após o Sete de Setembro de 1822, conferiu ao país uma marca racista da qual ele nunca se viu isento. Afinal, foi o último a abolir a escravidão em todo o continente americano. Durante a Colônia e o Império, foram enviados de diferentes localidades da África para o Brasil cerca de 4 milhões de escravos para dar sustentação ao capitalismo na Europa, sendo dito que as pessoas negras aqui escravizadas, por vias indiretas acabaram por ser uma força auxiliar na criação da classe operária assalariada no continente europeu.

Ao final do século XIX, os grupos da elite que vieram a se posicionar contra a escravidão e que buscavam alternativas à estagnação estrutural da economia agrária tinham um perfil urbano e uma aspiração capitalista mais consolidada. Vivia-se um ecletismo tosco naquele Brasil: onde a aristocracia agrária, uma massa escravizada e o status de cidadão conviviam a despeito da insatisfação gerada por interesses de grupos tão díspares. O espírito abolicionista era dominado por um imaginário de elite que "delimitava o horizonte do conflito: sem as massas, sem se irmanar com os negros e mulatos". (BEHRING; 
BOSCHETTI, 2006, p. 76). Na verdade, a aristocracia agrária aparecia como um freio à modernização no país, o que tornava lenta a urbanização.

Os interesses senhoriais e os interesses dos modernizadores, mais acelerados, chocavam-se, prevalecendo "uma acomodação intermediária, na qual se barganhava certa contenção da heteronomia nos níveis econômicos e técnicos, ao lado de uma contenção do mercado interno moderno" (Idem, p. 77), o que viria a neutralizar as vantagens de ordem econômica de um futuro Estado nacional. O controle da modernização estava nas mãos dos senhores e o crescimento, a partir do mercado interno, estava obstaculizado por eles. Isso tornava a aspiração modernizadora menos potente em seu anseio, uma vez que seus adeptos dependiam dos antigos setores agroexportadores para avançar de maneira aliançada.

É importante destacar que o trabalho livre nasceu no Brasil fadado a estreitar laços com o mandonismo, o clientelismo e o conformismo como se fosse um continuum ou um desdobramento histórico do trabalho escravo. Fernandes (1974) afirma que a ruptura apresentada com o citado enlaçamento não ocorre de maneira societária, histórica e política ao final do século XIX. Foi obtida muito mais em razão de incompatibilidades entre mercado colonial e mercado capitalista; trabalho escravo e trabalho livre; e produção colonial e produção capitalista. Assim, o modo de produção capitalista no Brasil teve uma expansão atropelada por legados autoritários não só no Período Colonial, mas também no Império e na República, e sempre com um alheamento das elites locais às necessidades das populações que aqui se formaram.

Se a Proclamação da República não serviu ao povo como era esperado, a Revolução de 1930 também não conseguiu melhor intento. Os segmentos oriundos do poder colonial fixaram-se como mandatários da nação, com toda a herança despótica de seus antepassados baseada na escravidão, na propriedade e cultivo de terras e na extração das riquezas que elas poderiam oferecer. A "Revolução de 1930"18 foi um feito não da burguesia industrial, mas de setores das oligarquias agrárias não ligados ao mercado externo. Esses setores "deslocam do papel de fração hegemônica no bloco de poder a oligarquia cafeeira, cooptam alguns segmentos da oposição da classe média (que se expressavam no movimento tenentista) e

\footnotetext{
18 O termo "Revolução" é cercado de controvérsias, havendo discordância sobre seu uso, tendo em vista que o que parecia evidente era um choque de interesses políticos entre oligarquias e não um projeto popular que envolvesse mudanças estruturais para o país. Sobre isso, Martins afirma: "Não podemos esquecer que a Revolução de 30, apesar de antioligárquica, foi composta com as oligarquias. O grande acordo político que Getúlio Vargas estabeleceu com as oligarquias foi com o objetivo de modernizar as relações de trabalho na cidade sem mexer nas relações de trabalho no campo, o que fez com que relações arcaicas persistissem durante um tempo larguíssimo". (MARTINS, 1997, p. 154).
} 
empreendem processos de transformação" (COUTINHO, 2006, p. 177), que somente com a implantação da ditadura do Estado Novo em 1937 estarão consolidados.

Naquele momento passa a se promover, sob a égide do Estado, um intenso e rápido processo de industrialização pelo alto. De um ponto de vista das lutas entre as burguesias pelo poder, desde a Era Vargas (1930-1945), passando pela República Populista (1945-1964) e pelo longo período da Ditadura Militar (1964-1985), o capital industrial teve uma predominância na condução do país. Coutinho (2006) assim resume as décadas em industrialização: Pode-se assim dizer que, a partir dos anos 1930 e pelo menos até a implantação do neoliberalismo nos anos 1990 (quando o capital financeiro assume a supremacia), a fração preponderante no bloco de poder que governou o Brasil foi o capital industrial. (COUTINHO, 2006, p. 176-177).

No decorrer de parte significativa da história brasileira, alguns elementos ou marcas foram se consolidando como constituintes de sua tessitura com ou sem "atualizações" no decorrer dos anos: 1) a relação entre liberalismo e mandonismo; 2) o caráter conservador daquilo que poderia ser novo: a Primeira República não trouxe os setores das classes subalternas coloniais, em sua multiplicidade, para o exercício do poder, tampouco representou a quebra do latifúndio. E mesmo a "modernização conservadora" (1964-1984) foi construída sob a égide de uma aliança entre o Estado nacional e os capitais financeiros nacional e internacional. Isso permitiu que o Estado passasse a viver de maneira combinada:

Com interesses oligárquicos e patrimoniais, que também se expressam nas políticas e diretrizes governamentais [...]. As desigualdades agravam-se e diversificam-se [...]. Moderniza-se a economia e o aparelho de Estado, mas as conquistas sociais e políticas [...] permanecem defasadas, expressando o desencontro entre economia e sociedade, que se encontra na raiz da "prosperidade dos negócios". (IAMAMOTO, 2008, p. 140).

A defasagem de conquistas para as classes trabalhadoras viria somada a uma terceira marca, qual seja: 3) a tendência em se naturalizar a "questão social"19 e em retirar dela seu caráter histórico, o qual está vinculado às contradições do modo de produção capitalista. Importa sublinhar que a "questão social" diz respeito tanto à "sociabilidade erguida sob o comando do capital” (NETTO, 2001, p. 46) quanto ao embate político determinado pela

\footnotetext{
${ }^{19}$ Um dos debates mais instigantes em Política Social, bastante encampado pelos diferentes cursos de Serviço Social, diz respeito ao que seja "questão social". Não se trata de um termo marxiano, no entanto mobiliza grande empenho em torno de si, particularmente de intelectuais marxistas. Pereira afirma que a questão social se materializa posteriormente à Revolução Industrial, "porque foi a partir dessa revolução que as relações sociais de produção foram modificadas a ponto de dividir toda a sociedade em duas grandes classes diretamente contrapostas: a burguesia e o proletariado". (PEREIRA, 2001, p. 59). A utilização de aspas em torno do conceito tem a ver com as múltiplas interpretações que ele pode tomar (NETTO, 2001), não raras vezes, no âmbito da intelectualidade mais conservadora.
} 
"contradição entre capital e trabalho e entre forças produtivas e relações de produção". (PEREIRA, 2001, p. 54). Conforme explica Iamamoto em diálogo com Ianni, esta última tendência "combina-se no pensamento social brasileiro, com o assistencialismo e a repressão, em uma criminalização científica da questão social”. (IAMAMOTO, 2008, p. 140). Assim, as demandas dos trabalhadores são subtraídas em sua legitimidade pela repressão estatal.

Particularmente em meados de 1970, ao se encerrar o ciclo de expansão da economia internacional iniciado após a II Guerra Mundial, as nações capitalistas conheceram uma nova crise de cunho estrutural, que tem seus efeitos replicados até hoje (PEREIRA, 2012). Pereira (2012) explica que frente à exacerbação da crise em 2008, o Brasil tem respondido com medidas que lhe dão sobrevida na qualidade de país neodesenvolvimentista. Isto ocorre em dois sentidos: reestruturando seu modelo econômico e diversificando a sua dependência externa, sem que se despreze a retomada da expansão econômica interna.

Nesse mister, o país, a par de servir, desde os anos 1990, de plataforma emergente de valorização financeira internacional [...], tem voltado a explorar suas reservas minerais e vegetais; a praticar o agronegócio; a exportar commodities e a reciclar a sua dependência externa, que agora deixa de ser tecnológica. (PEREIRA, 2012, p. 734).

Essa dependência, bem própria da acumulação industrial, passa a ser financeira, própria do rentismo, ou seja: “Além de o país voltar a sua antiga condição de produtor e exportador de bens primários, ou a sua vocação agrícola, ele se vê submetido ao que vem sendo denominado 'servidão financeira"”. (Idem).

Em torno da mesma problemática, Teixeira e Pinto (2012) afirmam que, mais precisamente depois de 2008:

Começaram a aparecer mudanças mais estruturais no bloco no poder brasileiro, potencializando fissuras na hegemonia da fração bancário-financeira, em virtude do fortalecimento de outras frações (segmentos exportadores de commodities e de parte da indústria nacional que passou a recuperar-se em termos absolutos) e dos efeitos econômicos e ideológicos da crise financeira internacional. (TEIXEIRA; PINTO, 2012, p. 933).

Toda essa ordem hoje colocada pelo capital repercute em insegurança e precarização para quem vive da venda da força de trabalho. Empregos aparecem e desaparecem de acordo com cotações em bolsas de valores nos países capitalistas centrais e periféricos. Os corações e mentes das massas trabalhadoras são abalados pela lógica cruel do mercado e pela perda crescente de agenda social nos diferentes Estados nacionais de todo o planeta, que, mediante as crises, erguem e destroem indústrias e cidades conforme os ditames da financeirização. É 
preciso reafirmar que não faz sentido para o capital, nos dias presentes, uma sociedade salarial. Dedecca nos lembra que:

Foi após a valorização do trabalho que foram construídas as políticas que permitiram a distribuição primária e secundária do excedente produtivo, processo que reiterou a atividade produtiva em detrimento dos circuitos financeiros de valorização da riqueza (AGLIETTA; RIGOT, 2009; LUSTIG; SYVERSON; VAN NIEUWERBURGH, 2009). Esse movimento foi reforçado por políticas econômicas que assumiram propósitos semelhantes, as quais foram possíveis graças ao papel jogado pelas instituições de organização e representação dos interesses coletivos. (DEDECCA, 2010, p. 12).

No entanto, a lógica financeira foi ganhando terreno em detrimento do investimento em uma lógica produtiva, processo que é reforçado pela desvalorização do trabalho no capitalismo nas três últimas décadas. Isso resultou na minoração dos salários, das rendas das famílias e do produto nacional. E gradativamente os salários foram perdendo sua:

Importância no processo de formação da renda, enquanto uma cesta diversificada de produtos financeiros foi ganhando espaço. Esse movimento tem assumido intensidade desigual no interior da sociedade, em razão de o acesso ao mercado financeiro estar diretamente relacionado ao estoque de ativos que as empresas e as famílias detêm. (DEDECCA, 2010, p. 13).

Infelizmente, somente os estratos mais privilegiados conseguem sobreviver a essa realidade sem danos substantivos. A desvalorização de seus salários é atenuada por ganhos de renda financeira, exatamente porque as famílias desses estratos têm maior densidade de ativos e o sucateamento dos serviços públicos em quase nada as atinge, nem o desemprego. $\mathrm{O}$ mesmo não acontece aos membros de famílias de classe média, que, sem tantos ativos, recorrem à solução individual de seus problemas, armando-se de conhecimentos que lhes garantam uma competitividade. As pessoas situadas na base da pirâmide socioeconômica são aquelas que mais sentem o impacto da desvalorização da sociedade salarial. Sem quaisquer recursos para salvá-las das situações difíceis, provocam no Estado a execução de:

Medidas que privilegiem o combate à pobreza, em detrimento daquelas relacionadas à distribuição do excedente e da riqueza. Um círculo vicioso de desvalorização salarial tem se consolidado para os estratos inferiores da distribuição de renda, invertendo o sentido da mobilidade social de ascendente para descendente. (DEDECCA, 2010, p. 13).

Como afirma Lyon-Callo (2008) em sua etnografia sobre sofridas populações de regiões estadunidenses outrora industrializadas, atualmente em franco sucateamento pela ostensividade das políticas adotadas nos Estados Unidos:

Neoliberal restructuring is much more than economic policy. It is a set of scripts-contested scripts-about globalization, the social, government, freedom, the market, and the body. These are being enacted locally as well 
as nationally. Yet, there is nothing inevitable or natural about such outcomes. (LYON-CALLO, 2008, p. 41).

O processo de financeirização ocorre gerando uma paralela desvalorização do trabalho que, como foi dito, origina outras mazelas, inclusive a paralisação do Estado, cedendo lugar ao mercado na esfera social. Ou, como situa Dedecca (2010): "É necessário entender as implicações da desvalorização da sociedade salarial, tanto nas mudanças do regime de regulação quanto nas consequências para a evolução da situação de desigualdade social e econômica no capitalismo desenvolvido". (DEDECCA, p. 12).

No Brasil, a realidade também é impactada pela financeirização ${ }^{20}$, essa última em resposta às crises do capitalismo. Os governos brasileiros neoliberais da década de 1990 tiveram o papel de arrumar ${ }^{21}$ o país dentro de uma ordem em que se defendia o capital das suas indefectíveis crises.

Em um contexto mais recente, na primeira década do século XXI de capitalismo com marca neodesenvolvimentista, os governos Lula e Dilma, eleitos com plataformas mais à esquerda, fizeram a opção por políticas distributivas voltadas para os setores mais pobres da população. Isso não quer dizer uma revolução como setores entusiastas gostam de propagar, afinal o capital financeiro não foi asfixiado pelos governos petistas, como explica Giovanni Alves ${ }^{22}$ (2013):

A opção pelos pobres tornou as políticas sociais menos onerosas para um Orçamento da União constrangido pelo pagamento dos serviços da dívida pública (por exemplo, investir no Bolsa Família é muito mais barato que investir na ampliação de uma educação e saúde pública de qualidade). Além disso, ao fazer opção pelos pobres, o neodesenvolvimentismo optou pelo "reformismo fraco" (como diria André Singer), evitando, deste modo, confrontar os interesses do grande capital financeiro-industrial e acirrar a luta entre capital e trabalho no país (eis o espírito do lulismo como neobonapartismo periférico). (ALVES, 2013, sem página).

\footnotetext{
${ }^{20}$ Sobre a referida resposta, Lavinas comenta em entrevista: “Tem vários estudos, inclusive nos Estados Unidos, que já mostraram que, depois da reestruturação da Ford, da General Motors - essas grandes montadoras americanas -, o faturamento delas é maior no financiamento à compra do carro do que na produção do carro. $\mathrm{O}$ grande problema hoje é essa financeirização. Isso muda completamente a lógica do capitalismo. A gente tinha uma noção de capitalismo industrial, que gera inovação, gera valor agregado, e a coisa mudou..." Disponível em:

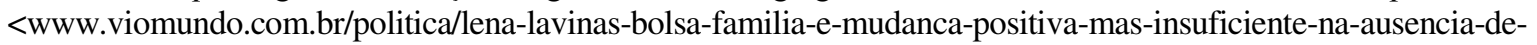
servicos-publicos-beneficia-sistema-financeiro.html>.

${ }^{21}$ Giovanni Alves (2013) explica que foi um momento de reformas estruturais na economia brasileira, tendo havido uma enorme recomposição patrimonial da riqueza brasileira, basicamente movida por uma transferência gigantesca de riqueza ou privatização de riqueza. Acrescentando que piores anos de ofensiva neoliberal, capitais estrangeiros, privatizações e fusões criaram uma nova burguesia no país agraciada por uma volumosa transferência do patrimônio e da propriedade no Brasil. Segundo o autor, naquele momento, cerca de $30 \%$ do PIB brasileiro mudou de mãos. (ALVES, 2013, sem página). Disponível em: $<$ http://blogdaboitempo.com.br/2013/05/20/neodesenvolvimentismo-e-precarizacao-do-trabalho-no-brasil-partei>.

${ }^{22}$ Disponível em: <http://blogdaboitempo.com.br/category/colunas/giovanni-alves>.
} 
Nesse quadro de indisposição governamental para enfrentamentos com as elites econômicas, com vistas a avanços sociais substantivos, a desigualdade social no Brasil permaneceu ocupando o posto de campeã na América Latina, refletindo-se em amplo espectro: "É também desigualdade na distribuição da riqueza socialmente produzida; é não acesso a serviços básicos, à informação, ao trabalho e a uma renda digna; é não participação social e política”. (SILVA, 2010, p. 157).

Em outras palavras, a desigualdade social caminha junto à desproteção das pessoas. E a desproteção social não é fator novo na história brasileira, conforme veremos a seguir.

\subsection{A proteção social}

A proteção $\operatorname{social}^{23}$ que um país oferece a seus habitantes está intimamente ligada ao momento de evolução de suas bases produtivas ${ }^{24}$ e à regulação político-social em andamento. Dessa maneira, as políticas sociais, em suas distintas matrizes de proteção social, "são desdobramentos e até mesmo respostas - em geral setorizadas e fragmentadas - às expressões multifacetadas e complexas da questão social no capitalismo". (BEHRING; SANTOS, 2009, p. 4). Devendo-se acrescentar que a proteção social não carrega em si nenhuma essência voltada para o bem, ou ainda inclinação intrinsecamente positiva, merecendo ser vista e analisada nos diferentes cenários dos países-nação em suas inevitáveis contradições.

\footnotetext{
${ }^{23}$ Camila Pereira (2013) debate em sua tese a dificuldade de se definir "proteção social", uma vez que há muitos autores buscando compreendê-la e colocá-la em prática. Nesse esforço intelectual, a autora trabalhou com três matrizes, dentro das quais se situam oito correntes teórico-ideológicas com proposições com maior ou menor proximidade ou distinção entre si. As três matrizes de proteção social são: a Matriz Residual que "traduz a proteção social relutante, admitida desde que seja pontual, emergencial, condicional, focalizada e mínima [...]. A Matriz Socialdemocrata [...] avança ao reconhecer a proteção social como direito a ser garantido ampliadamente. A universalidade, para essa matriz, ainda não é inteiramente bem-vinda, mas já é compreendida como estratégia segura a ser adotada na prevenção de crises ou solução de problemas sociais pela maioria dos estudiosos [...]. Por fim, a Matriz Socialista apresenta a defesa da proteção social pública, gratuita e universal, comprometida com a satisfação de necessidades humanas e a resolução (ou, ao menos, alívio) dos males sociais causados e perpetuados pelo capitalismo". (PEREIRA, 2013, p. 283). Importante acrescentar que cada matriz tem sua composição teórica, dessa maneira, a primeira delas é alimentada pela Teoria Funcionalista, Teoria da Convergência e Ideologia da Nova Direita; a segunda, por sua vez, agrupa a Teoria da Cidadania, Ideologia da Via Média e Administração Social; e, finalmente, a terceira, que vem a ser constituída pela Ideologia do Socialismo Democrático e Teoria e Ideologia Marxistas. A autora conclui que o termo proteção social "encerra em si um ardil ideológico, a ser teoricamente desmontado, visto que ele falseia a realidade por se expressar semanticamente como sendo sempre positivo [...]", porque "[...] a proteção social, onde quer que tenha sido empregada, sempre foi alvo de interesses discordantes entre os seus estudiosos, executores e destinatários". (PEREIRA, p. 285).

${ }^{24}$ À guisa de exemplo, o agrário-exportador ou urbano-industrial.
} 
No caso brasileiro, a proteção social pode ser periodizada em: Período Laisseferiano (antes de 1930), Período Populista Desenvolvimentista (1930 a 1964), Período Tecnocrático Militar (1964 a 1985), Período da Transição para a Democracia Liberal (1986 a 1990) e Período Neoliberal (de 1990 até nossos dias). (PEREIRA, 2000). A periodização diz respeito, em linhas gerais, a como o Estado se portou frente às demandas sociais no decorrer de nossa história. No início da República, Período Laisseferiano, o Estado pouco exercia o papel de regulação da área social, de tal forma que não geria a provisão social, deixando a tarefa a serviço do mercado, da iniciativa privada não mercantil e sob a repressão policial.

No período populista desenvolvimentista, assiste-se a uma mudança econômica acelerada na passagem da economia agroexportadora para urbano-industrial. Apesar de uma mudança tão drástica no plano produtivo e econômico, o plano social não foi acompanhado de significativa mudança. A proteção social não passou por uma planificação central até meados da década de 1950.

O Período Tecnocrático militar tem como característica marcante a tecnocratização e a centralização do Estado, antes organizado de maneira a atender interesses populistas. Nesse período de forte autoritarismo fundamentado na força militar, o saber técnico adquire supremacia, o planejamento direto é privilegiado e a racionalização burocrática se efetiva, dando suporte à reestruturação da máquina estatal. No tocante às políticas sociais, houve subperíodos em que ela se intensificou, especialmente quando era do interesse do Estado aproximar-se mais da sociedade. No período da transição para a democracia liberal, a chamada Transição Democrática, o país se desatrelava aos poucos da Ditadura Militar. Conseguiram-se dois intentos naquele momento: convocar uma Assembleia Nacional Constituinte (ANC) e lograr êxito na construção de uma concepção de proteção social "na qual tanto os direitos sociais quanto as políticas sociais concretizadoras desses direitos receberam uma atenção especial”. (PEREIRA, 2000, p. 148).

Dentre as várias lutas dos setores populares nesse momento especial da vida republicana, podemos citar importantes conquistas. Constam do plano dos direitos sociais: seguridade social, universalização, descentralização político-administrativa, controle democrático, "mínimos sociais", configurando novos patamares a uma política social sempre raquítica em serviços e atendimentos à população. A seguir, apenas algumas dessas inovações, tendo em vista que outras serão abordadas mais adiante.

$\mathrm{Na}$ área social previu-se uma regulação mais intensa do Estado; financiamento e provisão de políticas sociais; universalização do acesso a benefícios e serviços; ampliação do 
caráter distributivo da política social, como um contraponto ao seguro social de caráter contributivo; controle democrático exercido pela sociedade sobre os atos e decisões estatais; redefinição dos patamares mínimos dos valores dos benefícios sociais e adoção de "mínimos sociais" como um direito de todos. (PEREIRA, 2000). No campo do trabalho, apresentam-se algumas conquistas: redução da jornada de trabalho de 48 para 44 horas semanais; redução dos turnos de revezamento para 6 horas; férias remuneradas anualmente com mais um terço salarial; extensão do Fundo de Garantia do Tempo de Serviço (FGTS) para todos os trabalhadores após dois anos de contrato; estabilidade para todos os servidores públicos; inclusão do seguro-desemprego como direito de trabalhadores urbanos e rurais. (PEREIRA, 2000).

Na esfera da educação podemos citar como progressos: ratificação do princípio da universalização do ensino fundamental; ampliação de $13 \%$ para $18 \%$, no mínimo, do percentual das Receitas da União a serem destinadas à educação; transformação da creche em um serviço educacional de especial importância para crianças com idade inferior a seis anos; manutenção da gratuidade do ensino público em todos os níveis. Naquilo que diz respeito à seguridade social, houve um avanço considerável, ainda que apenas três políticas tenham se encerrado dentro dela: Saúde, Assistência Social e Previdência Social, esta última de caráter contributivo. Elas foram contempladas com uma nova concepção de financiamento, sustentado por orçamento e fundos únicos. Particularmente, na Assistência Social, a configuração dos direitos ampliou-se radicalmente, deixando para trás as concepções de que a assistência era favor; e seu beneficiário, um desamparado.

Houve uma ruptura com a "prática assistencialista largamente utilizada como instrumento de barganha populista ou de patronagem política, herdada da Era Vargas, bem como o caráter eminentemente contributivo de proteção social”. (PEREIRA, 2000, p. 156). Uma fundação tão bem cimentada daria sustentáculo a outras conquistas, tais como: a incumbência da política de Assistência Social em materializar direitos relacionados às famílias, gestantes, nutrizes, crianças, adolescentes, pessoas com deficiência e desempregados afetados em suas necessidades básicas, o que não veio a ocorrer como o esperado pelos setores organizados em prol de uma Assistência Social universalizada.

Somadas essas possibilidades, ocorre a conquista constitucional, configurada como direito básico, do Benefício de Prestação Continuada (BPC), no valor de um salário mínimo, destinado às pessoas idosas e com deficiência, cujas rendas familiares per capita fossem de até um quarto do salário mínimo. O BPC surge como um dos maiores avanços de nossa 
legislação em todos os tempos, embora venha sendo assediado na atualidade por propostas insistentes de vinculá-lo a contrapartidas laborais por parte de seus beneficiários, caracterizando um modelo de workfare, distante do almejado e civilizatório welfare, além de encontrar-se condicionado a critérios de seletividade para ser alcançado.

Apesar de avanços substantivos obtidos no texto constitucional (controle democrático sobre atos e decisões estatais; maior responsabilização estatal na regulação, financiamento e provisão das políticas sociais, entre outros), não se assistiu ao usufruto, por parte da população, daquilo que foi conquistado de maneira tão penosa: após duas décadas sob Regime Militar, a contrarreforma iniciada pelo então Presidente José Sarney e posteriormente continuada pelo Presidente Fernando Henrique Cardoso (FHC), que se incumbiu de minar esperanças em torno de uma efetiva proteção social.

O Período Neoliberal é pautado pela adoção de medidas que comprometem gradativamente todo o resultado de avanço que as políticas sociais poderiam representar, caso tivessem sido cumpridas de acordo com a Constituição. É o momento em que o país segue com afinco os receituários do Fundo Monetário Internacional (FMI) e do Banco Mundial (BM) no campo econômico e no que diz respeito às políticas sociais derivativas do modelo econômico adotado. Dessa forma, os serviços públicos são abalados por inúmeros agentes, entre eles: o subfinanciamento, o crescimento do setor privado, o investimento ideológico no papel do voluntariado e das Organizações não Governamentais (ONG) em sua consecução, o sucateamento de seus equipamentos, a terceirização e a subcontratação de amplos contingentes de trabalhadores, além da desqualificação de debates importantíssimos como a crítica aos mínimos sociais. A Constituição Federal chegou a ser rotulada pelos conservadores de inviável e inconsequente frente aos avanços que obteve, o que se configura como absurdo se verificamos o deserto em termos de proteção social nos períodos anteriores a sua promulgação.

As elites econômicas brasileiras, insatisfeitas com as conquistas dos setores populares no texto da Carta Magna, não cessaram suas lutas em favor de interesses liberalizantes. A internacionalização da economia era incompatível com a proteção social verificada no texto constitucional. $\mathrm{O}$ ataque burguês foi incessante, centrando fogo contra: a) a reforma agrária com a extinção do ministério com esse mesmo nome; b) o fechamento do Banco Nacional da Habitação (BNH), seguido do "esquecimento" do projeto de reforma para o Sistema Financeiro de Habitação; c) a redução orçamentária com desmonte institucional, principalmente nas áreas de transporte público, alimentação e reforma agrária; d) vários 
dispositivos constitucionais deixaram de ser regulamentados por severa oposição governamental à Carta Magna.

O clima intenso de contrarreformas foi coroado com a eleição do Presidente Fernando Collor de Mello, em meio a uma crise econômica, com discursos incisivos de combate à corrupção. As determinações externas provenientes do capitalismo dos países centrais exigiam menos Estado e mais mercado. As políticas sociais universais devidamente orçadas e financiadas não fariam mais sentido para um mundo financeirizado.

No aprofundamento de uma política econômica neoliberal, o Brasil ingressa em uma fase do desenvolvimento capitalista que se inicia nos dois governos de Fernando Henrique Cardoso e que se aprofunda nas gestões de Luiz Inácio Lula da Silva e Dilma Rousseff. "Na esteira das transformações estruturais, constata-se o surgimento de uma ideologia que se propõe como guia dos rumos do desenvolvimento capitalista brasileiro, o novo desenvolvimentismo". (CASTELO, 2013, p. 613). Este vem sendo um momento carregado de controvérsias entre personagens do campo progressista, até porque intelectuais de peso, nesse campo, vêm falando em pós-neoliberalismo (vide Emir Sader), embora os processos de supressão e precarização dos direitos ou de sua mercadorização continuem em andamento sem qualquer ruptura com os processos de financeirização.

\subsection{Infâncias e as Políticas de Educação e Assistência Social em revista}

Quando nos reportamos à infância e eventualmente à adolescência, estamos tratando de duas construções sociais modernas. Embora a criança seja uma construção bem anterior à Modernidade, a infância propriamente dita nasceu nesse mesmo longo período, dando sinais de que é uma invenção que ainda não se esgotou, ainda que em alguns grupos sociais seja abreviada por necessidades voltadas à sobrevivência (trabalho infantil) ou por demandas por consumo. Dessa maneira, a infância e a adolescência não são tratadas no presente trabalho como etapas do desenvolvimento naturais e universais, mas como etapas carregadas de historicidade e de práticas culturais, vinculadas a uma base econômica, que se apoiam, com maior ou menor intensidade, num corpo biológico. Assim, a infância de uma criança burguesa franzina aos 10 anos não será a mesma infância de uma criança proletária franzina na mesma idade. À segunda serão impostas tarefas e privações que jamais serão pedidas e sofridas pela primeira, mais protegida e lembrada de seus direitos, mormente se ambas viverem em uma 
localidade com uma frágil presença do Estado em seu papel social. O mesmo raciocínio caberia a adolescentes oriundos dessas mesmas classes sociais.

Nesse sentido, Marx (1984) preocupou-se em tratar de uma infância alijada de direitos. Deteve-se na questão do trabalho infantil e em mostrar o peso do trabalho das crianças na produção em plena Revolução Industrial. O filósofo alemão não se deteve especificamente na temática "infância" em seus escritos, mas tinha um olhar especial para os infantes submetidos a jornadas de intenso trabalho no mundo fabril. Cabe lembrar que o trabalho infantil existiu anteriormente ao capitalismo:

Mas a difusão em larga escala do trabalho infantil foi obra da Revolução Industrial: em 1861 um censo realizado na Inglaterra registrava que quase $37 \%$ dos meninos e $21 \%$ das meninas de 10 a 14 anos trabalhavam, fato também observado em outros países, que também apresentavam taxas altas de crianças trabalhando [...]. (LOMBARDI, 2010, p. 145).

Lombardi (2010) observa que a presença de mulheres e crianças na fábrica representava um barateamento nos custos da força de trabalho. Os custos do trabalho de uma criança não ultrapassavam a metade ou um terço da força de trabalho de um adulto, o que viria, por outro lado, a minorar os salários desse último. A própria entrada da maquinaria na fábrica permitiu a relativa abolição da força muscular, instaurando uma nova realidade, em que mulheres e crianças passariam a ser mais interessantes economicamente ao patronato.

À medida que a maquinaria torna a força muscular dispensável, ela se torna o meio de utilizar trabalhadores sem força muscular ou com desenvolvimento corporal imaturo, mas com membros de maior flexibilidade. Por isso, o trabalho de mulheres e crianças foi a primeira palavra de ordem da aplicação capitalista da maquinaria. [...] O trabalho forçado para o capitalista usurpou não apenas o lugar do folguedo infantil, mas também o trabalho livre no círculo doméstico, dentro de limites decentes, para a própria família. (MARX, 1984, p. 23).

Não sem motivações, a expressão "questão social" tem seu aparecimento nesse mesmo século de exploração exacerbada. Netto (2001) informa-nos que todas as indicações disponíveis sugerem que seu surgimento tenha ocorrido aproximadamente na terceira década do século XIX, vindo a traduzir toda uma ordem de insatisfação dos trabalhadores pauperizados em suas nascentes organizações. Esse fato levou o Estado britânico a realizar estudos entre 1830 e 1840 para entender melhor o que se passava entre os trabalhadores em suas lutas reivindicatórias.

Os estudos realizados naquele momento verificaram que a "questão social" era “estritamente relacionada à concentração populacional, imigração do campo para a cidade, 
urbanização, industrialização e baixa eficiência do Estado na área social a partir da lei dos pobres". (BRANCO, 2006, p. 16). Também as crianças eram impactadas por todos esses fenômenos. E pior, o seu uso efetivo, juntamente com as mulheres no trabalho fabril, fez com que o movimento operário sofresse um arrefecimento de forças, uma vez que passou a haver o barateamento da força de trabalho e a disputa por emprego na fábrica. O significativo aumento da oferta permitiu que os salários caíssem, aumentando a miséria das famílias operárias. Compreendemos, então, que as crianças e os adultos viviam juntos situações antagônicas: existiam sob um mesmo pauperismo, partilhavam o mesmo parco pão e competiam pelos mesmos locais de trabalho. Frente às situações de pura desproteção em que vivessem, restavam as medidas caritativas ou a prisão.

Contraditoriamente, a classe capitalista precisou educá-las, não por altruísmo, mas por imperativos do próprio capital. Sobre esta questão, Saviani (2007) afirma que:

Com o impacto da Revolução Industrial, os principais países assumiram a tarefa de organizar sistemas nacionais de ensino, buscando generalizar a escola básica. Portanto, à Revolução Industrial correspondeu uma Revolução Educacional: aquela colocou a máquina no centro do processo produtivo; esta erigiu a escola em forma principal e dominante de educação. (SAVIANI, 2007, p. 159).

Ainda que o Brasil não tivesse se industrializado no século XIX, a situação das crianças pobres no país nunca foi confortável. Se não padeciam as agruras do trabalho fabril, outras aflições apresentavam-se em profusão por diferentes razões: pelo trabalho infantil escravizado ou não, abandono, fome, castigos físicos e pela repercussão de ações consideradas delituosas, que poderiam resultar ou não em uma institucionalização. Cristo e Rangel (2004) sintetizam a trama cruenta em que particularmente as crianças escravizadas viviam:

Assim como aos filhos de escravos se garantia o sustento em troca de sua "participação" nos afazeres domésticos, atribuindo-lhes funções como a de brincar com os filhos dos senhores, submetidos às suas ordens, auxiliar os pais em suas tarefas, enfim, inserir-se, desde cedo, em seu universo de deveres. Os órfãos, abandonados e desvalidos ocuparam, também, esse lugar, com o surgimento de leis restritivas à escravidão. (CRISTO; RANGEL, 2004, p. 75).

Da mesma maneira, às crianças indígenas não eram reservados destinos carregados da proteção, ternura e paparicos, típicos da infância descrita por Ariés (1978) no decorrer da Modernidade europeia, no seio das classes mais abastadas. O mundo colonial precisava cumprir o destino de subalternizá-las em suas próprias terras de origem, o que repercutiu em suas tutelas por meio da catequização jesuítica e de outras ordens religiosas, onde "recebiam 
ensinamentos voltados para o trabalho, assim como eram educadas de acordo com os costumes e normas das sociedades europeias". (HENRIQUES, 2007, p. 12).

Em larga parte do Período Republicano, o quadro de quase abandono vivido por adolescentes e crianças pobres, relacionado à negligência de políticas para ambos por parte das classes proprietárias, ensejava a ação consorciada entre assistência e poder judiciário, com resultados, não raras vezes, bastante violentos. A internação em abrigos das crianças mais expostas a sociabilidades estranhadas pelos setores dominantes aparecia como um recurso reparador de uma população não adulta que supostamente oferecia perigo para a sociedade. $\mathrm{O}$ esperado dessas populações era apenas o oferecimento ao patronato da força de trabalho mal remunerada.

O Plano Nacional de Convivência Familiar e Comunitária (PNCFC), construído no mais recente Período Republicano, dispõe que o Poder Público por muitas décadas desenvolveu políticas para o controle e contenção social, fazendo-o sem qualquer preocupação substantiva com a manutenção de vínculos familiares entre crianças e seus responsáveis. Tal disposição versa sobre a aventada "incapacidade" de algumas famílias, sobretudo as pobres, de orientarem seus filhos. Um trato tão desqualificado perante os pobres teve como desdobramentos a prática provisória de suspensão do poder familiar ou mesmo a destituição dos pais e de seus deveres para com a prole.

A engenharia construída com o sistema de proteção e assistência, sobretudo durante o século passado, permitiu que qualquer criança ou adolescente, por sua condição de pobreza, estivesse sujeita a se enquadrar no raio da ação da Justiça e da assistência, que sob o argumento de "prender para proteger" confinavam-nas em grandes instituições totais. (BRASIL, 2006, p. 16).

O desenho dessa prática pretérita de assistência e de proteção estava articulado com a tarefa educativa. A seguir, a exposição de como isso se verificava.

\subsubsection{A política educacional}

Ao falarmos de política educacional em distintos períodos da vida brasileira, não poderíamos nos furtar ao debate daquilo que entendemos por educação. Entendemo-la como detentora de forte papel na emancipação humana, "uma vez que tem a função particular de mediar a produção cultural (o conhecimento elaborado historicamente) na relação entre a 
dimensão universal, própria do ser genérico, e a dimensão singular, própria do ser individual”. (BERNARDES, 2010, p. 293). Certamente a mediação pela educação não é fator único para a emancipação humana ${ }^{25}$, mas sem a primeira a segunda não ocorre.

Compreendemos que a necessidade de emancipação das pessoas define os motivos da atividade pedagógica ${ }^{26}$. No processo de emancipação estão envolvidos quem ensina e quem aprende, sendo que ambos, ao assimilarem o conhecimento universal acumulado, se autoproduzem, superam-se física e psiquicamente por meio do movimento dialético que transforma a natureza interna e externa de homens e mulheres. Nesse sentido, os objetivos pedagógicos devem ter como centro a apropriação da produção humana elaborada historicamente, visando ao processo de humanização. É preciso que não esqueçamos os limites da educação em uma sociedade de classes forjada na alienação, para que não esperemos dela aquilo que é impossível em uma sociedade regida pelo capital, que vem a ser uma relação anterior ao capitalismo, que não sucumbe nem com sua extinção. (MESZAROS, 2002). É dentro desse cenário de possibilidades e impossibilidades da educação que faremos uma breve historicização de sua versão escolarizada no contexto brasileiro.

\subsubsection{A educação durante o Período Colonial}

Durante a Colônia, a educação em terras brasileiras ocorreu como objeto de adequação aos interesses de Portugal. Os jesuítas, pelo caminho da catequização, cumpriram importante papel de ajustar os colonizados aos interesses mercantilistas do colonizador. A educação aqui fornecida é vista por Sodré (1974) como:

"Força de conservação", o "ensino de classe, dogmático e retórico",
padronizava a cultura, formava reduzida e rala minoria de letrados, ilhada
pelo total desinteresse dos demais, marginalizada pelo conteúdo de alienação
implícito no que aprendia e cultivava, desprovido tudo de senso crítico e
distante do espírito criador. (SODRÉ, 1974, p. 19).

Ler, escrever e contar apareciam como tarefas suficientes no processo de transplantar a cultura da terra dos colonizadores e subjugar as diferentes culturas nativas. Nada mais

\footnotetext{
25 Sobre a emancipação humana, concordamos com Tonet (2005) que ela é radicalmente superior e distinta da cidadania, a qual se funda em uma liberdade muito limitada. A emancipação humana diz respeito a uma forma de sociabilidade na qual os homens sejam efetivamente livres, supondo a eliminação do capital.

${ }^{26}$ Conforme Bernardes (2010), a atividade pedagógica vem a ser a atividade humana em geral que considera os sujeitos ativos no processo de aprendizagem e desenvolvimento.
} 
sofisticado era do interesse das elites coloniais. O plano educacional de Manoel da Nóbrega, considerado o primeiro elaborado no país, foi rechaçado com a instalação das Companhias de Jesus em nosso território. Consistia em alargar o espectro curricular, adotando o ensino de artes além do ensino profissional e agrícola para filhos de caciques, filhos de colonos, órfãos e grupos mestiços. Pretendia-se, assim, apenas catequizar os índios e os demais grupos do povoamento, e aos filhos dos colonos seria destinada a instrução. Formava-se, dessa maneira, uma elite colonial. Viriam a receber uma educação limitada pelo dogmatismo, ancorada na escolástica e sem apreço pelo questionamento, pela ciência, pelas artes e pela experimentação.

A ascensão do Marquês de Pombal no Brasil com fins de modernizar a cultura portuguesa aqui transplantada veio a representar a expulsão dos jesuítas e o seu modelo curricular restritivo, voltado para o domínio religioso. O fato de Portugal não ter ultrapassado o mercantilismo construiu a necessidade de que as elites portuguesas tivessem maior empenho para com a educação da Colônia, agora voltada para interesses estatais e não para os fins religiosos. Novos cargos seriam criados no intuito de uma evolução no capitalismo português e era preciso preparar a população adequadamente. A educação primária passa a ser ministrada na escola a partir de então, inaugurando o ensino efetivamente público no país, porém voltado para poucos.

O ciclo de mineração do século XVIII trouxe novas demandas de escolarização para uma nascente classe intermediária: a pequena burguesia precoce surgida no período. A burguesia que aparece à época não se coloca a serviço das populações e das oprimidas culturas locais manifestas em inúmeras obras do barroco brasileiro, executado por artistas não prestigiados pelas elites, muitos oriundos da inter-racialidade. Sequer a chegada da Família Real portuguesa ao Brasil, em um momento de baixa do ciclo minerador, representou avanços para uma cultura local que vinha se manifestando por diferentes expressões artísticas.

A proclamação da Independência em 1822 não fez com que as elites recuassem de um projeto de educação de feições coloniais restrito a seus membros. Ao contrário, ele se acirrou na medida em que novos cargos na administração advieram desse fato histórico. Organizaram-se novos cursos destinados a formar quadros da elite para o novo momento político, inclusive os cursos superiores formados a partir do Império estavam imbuídos desse fim. O Período Republicano não foi benevolente com os setores populares também. Finda a escravidão, toda uma população negra ou mestiça antes escravizada viu-se longe das poucas vagas escolares ofertadas na Primeira República, bem como a população branca pobre. 


\subsubsection{O Período Republicano}

Não é surpreendente afirmar que já em 1894, poucos anos passados da Proclamação da República, houve um arrefecimento do entusiasmo pela educação. As oligarquias, em um exercício solitário de poder, esvaziaram os debates esperançosos por uma república democrática, deixando de fora do seu arco de preocupações prioritárias questões como o federalismo, industrialização e educação popular. O comércio de café e a manutenção do poder por meio de mecanismos eleitorais pouco ou nada democráticos (voto não secreto, fraudes, voto de cabresto, corrupção) tornaram-se suas demandas mais emergentes. (GHIRALDELLI, 1990). Mesmo os planos para a educação, formulados pelas elites dirigentes, foram sufocados pelas oligarquias cafeeiras nos primeiros vinte anos de vida republicana.

Em 1920, o país tinha 75\% de sua população analfabeta, sendo que iniciara, nos anos 1910, um processo de industrialização e de urbanização. Nesse período, em plena I Guerra Mundial, o Brasil vivia um clima de nacionalismo que levou os intelectuais a retomarem a luta, antes sufocada, por educação. Até porque ela poderia ser um instrumento contra a despolitização, em um país em que só alfabetizados votavam. Diferentes ligas contra o analfabetismo, oriundas de setores também da elite como intelectuais, médicos e industriais, formaram-se para dar uma nova feição ao Brasil. A Liga Nacionalista do Brasil, por exemplo, acreditava que o analfabetismo colaborava para a manutenção das oligarquias no governo, almejando assim a alfabetização como meio de alterar o quadro político-eleitoral. Era a burguesia urbana nascente confrontando os interesses das oligarquias cafeeiras. Juntaram-se a ela setores das classes médias, também insatisfeitos e que possuíam algum grau de vinculação com o Governo.

As transformações ocasionadas após a I Guerra Mundial, quando a Inglaterra perde espaço comercial e financeiro para os Estados Unidos, fazendo com que o Brasil se aproxime deles em seus negócios e trazendo inúmeras mudanças no âmbito cultural brasileiro. O estilo de vida americano torna-se paradigma para a intelectualidade do país. Instala-se aqui nos anos 1920 o Escolanovismo, encetado pelos americanos John Dewey e William Kilpatrick (GHIRALDELLI, 1990), conquistando adeptos até algumas décadas depois. Era o período do otimismo pedagógico, que mobilizava a sociedade política, levado à frente por intelectuais que cumpririam papel importante no debate da educação dos anos 1930. Na década anterior, quem tomou para si a luta pela escolarização foram os entusiastas da educação, que se 
expressavam por meio de entidades da sociedade civil, as ligas já mencionadas, que tinham forte papel em incentivar a alfabetização.

Todo esse debate entre otimistas e entusiastas da educação, ambos representando segmentos elitistas, tinha razão de ser, ainda que suas defesas não fossem num campo de marca progressista. A Primeira República não viu a construção de uma rede de escolas públicas que contemplasse os setores populares. Se houve uma diversificação de classes sociais no período, a expansão do ensino público ocorreu mais acentuadamente nos ensinos secundário e superior, muito distante do alcance dos trabalhadores e suas proles. Somente nos anos 1930 viu-se um debate de maior vulto sobre os projetos para a educação brasileira, após a perda de poder das oligarquias cafeeiras e a posse de Getúlio Vargas como Presidente, em um governo provisório.

Nesse contexto, liberais, integralistas, governistas e os setores populares chamados de aliancistas (Aliança Nacional Libertadora) deram substância ao debate educacional da época. Não se queria educação nos moldes oligárquicos da Primeira República. É preciso dizer que a posse de Getúlio Vargas redefiniu o quadro político naquele momento, propiciando a saída de cena das oligarquias agroexportadoras, que foram substituídas por militares, tecnocratas e industriais. As tensões entre grupos tão distintos tiveram fim com a promulgação da Carta Constitucional de 1934. A Carta previu ensino primário obrigatório, fiscalização e regulamentação dos estabelecimentos de ensino público e particular, fixação de recursos no orçamento para educação e dotação orçamentária para as escolas rurais. Concomitantemente, houve a forte influência católica no texto que barrou as ideias de neutralidade e laicidade na escola pública.

De maneira distinta, a Constituição autoritária de 1937 desincumbia o Estado do ensino público na sua manutenção e expansão, inclusive a gratuidade veio a ser ferida. Aos infantes pobres estava decretado o destino das escolas profissionais, uma vez que os ricos poderiam ter a opção de ir à escola pública pagando a caixa escolar ou mesmo encaminharem-se ao ensino privado de maneira imediata. A escola pública para a pobreza ficava condicionada à sua escolha pelo ensino profissional, sendo que a Constituição em exame sequer legislou sobre dotação orçamentária para a educação. Trata-se de uma Carta feita para conter o clamor popular por mais avanços.

A política educacional centralizadora que se instaurou traduziu-se na promulgação, entre 1942 e 1946, das Leis Orgânicas, por iniciativa do Ministro da Educação do Estado Novo, Gustavo Capanema. Essas leis, chamadas de "Reforma Capanema", consubstanciaram-se em seis 
decretos-leis que ordenaram os ensinos primário, secundário, industrial, comercial, normal e agrícola. Contraditoriamente, a legislação educacional do Estado Novo delineou o que se pode chamar de sistema educacional para o nosso país. (SAVELI, 2010, p. 135).

A derrubada de Vargas representou um retorno, em grande parte, ao que estava disposto na Carta de 1934 por meio da promulgação da Carta de 1946. Os estados e Distrito Federal passaram a ter por dever organizar seus sistemas de ensino, e somente em 1961 se promulgou uma Lei de Diretrizes e Bases para tal execução. Figuram no novo texto constitucional "a obrigatoriedade e a gratuidade do ensino primário, o direito de todos à educação, bem como a vinculação de percentuais da receita de impostos para a manutenção e o desenvolvimento do ensino [...]”. (Idem, p. 136).

Importante mencionar que a LDB $\mathrm{n}^{\mathrm{o}} 4.024 / 61$ previu apenas quatro anos de escolarização obrigatória junto à descentralização do ensino. Esse Período Democrático teve fim com o Golpe Militar de 1964, quando novamente iniciaram as decisões centralizadas em âmbito educacional. Somente em 1967 uma Carta Constitucional explicita a faixa etária destinada ao ensino obrigatório, em pleno Regime Militar. Como lembra Saveli (2010):

De acordo com a referida lei, o ensino fundamental (primário) passaria de quatro para oito anos obrigatórios. No entanto, o estabelecimento da faixa etária dos 7 aos 14 anos não representou a efetiva ampliação da escolaridade obrigatória, tendo em vista que a gratuidade era garantida apenas nos estabelecimentos primários oficiais. (SAVELI, 2010, p. 137).

Em 1969, opera-se nova mudança pela Emenda Constitucional $n^{\circ} 1$, de 1969. O texto legal passa a ter a seguinte redação: “art. $176, \S 3^{\circ}$, II - o ensino primário é obrigatório para todos, dos 7 aos 14 anos, e gratuito nos estabelecimentos oficiais". Em 1971, uma nova LDB é promulgada. O primeiro grau passa a ser o somatório do ensino primário com o ginasial, perfazendo agora oito anos de escolarização obrigatória. Conforme analisa Ghiraldelli (2006, p. 124), esta lei "refletia, em boa medida, os princípios da Ditadura Militar, verificados pela incorporação de determinações no sentido de uma racionalização perversa do trabalho escolar $[\ldots]$..."

O término da Ditadura Militar e o consequente processo de abertura política que culminou na Assembleia Nacional Constituinte (ANC) de 1987 mobilizaram muitos agentes que queriam a democratização da educação pública em distintos aspectos e lograram êxito ao inscrevê-la como um direito social na nova Carta. O ensino fundamental passa a ser obrigatório, ou seja, qualquer cidadão, em qualquer idade, tem garantido esse direito e pode exigi-lo a qualquer momento perante as autoridades cabíveis. Em 1990, o ECA vem 
referendar essa obrigatoriedade constitucional para crianças e adolescentes, particularmente, em seu art. 54.

Do ponto de vista da qualidade de ensino, os arts. 205, 206 e 208 articulam textos que balizam essa preocupação para diferentes grupos do alunado, delimitando princípios, garantias e responsabilidades para uma boa escolarização. A inovação mais recente na escola pública brasileira foi a ampliação do ensino fundamental obrigatório para nove anos, viabilizado pela Lei $\mathrm{n}^{\mathrm{o}}$ 11.274/2006. Saveli (2010) explica que “a antecipação da obrigatoriedade escolar representa um avanço muito importante na busca de inserção das crianças das classes populares nos sistemas educacionais brasileiros”. (SAVELI, 2010, p. 143).

Diante dessas conquistas legais, é preciso ressaltar que o avanço precisa vir acompanhado de qualidade, como dispõe o art. 206 da Constituição. Colocar em prática o que está no texto constitucional também se verifica como uma luta atual. Os contingenciamentos na área da educação e o descumprimento pelos estados e pela União dos mínimos constitucionais atacam violentamente o que já está garantido em termos de obrigatoriedade e minam esperanças de que a universalização da educação básica, forjando escolas com qualidade $\operatorname{social}^{27}$, se torne uma realidade. Isso sinaliza que o direito à educação possui contornos mais complexos do que o senso comum pode perceber, conforme ressalta Aboites (2012):

El derecho a la educación no es sólo ni principalmente la expresión de un proceso civilizatorio, lineal y progresivo orientado a una constante mejoría, ampliación y afinamiento de su aplicación, así como de esfuerzos por mejorar su exigibilidad y justiciabilidad. La manera como se concibe este derecho y sus alcances así como sus momentos de ampliación, estancamiento o retracción son más bien expresiones de las confrontaciones políticas e ideológicas, de los grandes acuerdos que resultan de luchas sociales intensas, del surgimiento e imposición de nuevos actores en el terreno de la educación y de las luchas de resistencia contra la restricción de ése y otros derechos semejantes. (ABOITES, 2012, p. 1).

\footnotetext{
27 Reportamo-nos a uma escola de "qualidade social referenciada", que não precise estar inserida necessariamente em um padrão único de qualidade. Como elaboram Fernandes e Oliveira (2009, p. 207), “entende-se que é fundamental estabelecer a definição de dimensões, fatores e condições de qualidade a serem considerados como referência analítica e política no tocante à melhoria do processo educativo e, também, à consolidação de mecanismos de controle social da produção, à implantação e monitoramento de políticas educacionais e de seus resultados, visando a produzir uma escola de qualidade socialmente referenciada." Assim exposto, temos um horizonte que dista do universo teórico da Qualidade Total, construído para hegemonizar a educação com um viés empresarial.
} 
Depois de muitas manobras no Congresso Nacional no processo de sua construção, a nova LDB, Lei $\mathrm{n}^{\circ}$ 9.394, foi promulgada no Governo do Presidente Fernando Henrique Cardoso, em 1996. Frigotto e Ciavatta (2003) lembram que:

O infindável processo de tramitação da LDB e as centenas de emendas e destaques feitos pelos parlamentares da base de governo, em verdade, eram uma estratégia para ganhar tempo e ir implantando a reforma educacional por decretos e outras medidas. O pensamento dos educadores a sua proposta de LDB não era compatível com a ideologia e com as políticas do ajuste [...]. (FRIGOTTO; CIAVATTA, 2003, p. 109).

Em razão disso, educadores empenhados em um projeto progressista sofreram sistemático combate e rejeição dos setores elitistas ou dos aliançados a eles. Nem a desfiguração do projeto popular, via proposição "alternativa” de um projeto de Darcy Ribeiro, surtiu tanto efeito, uma vez que interessava às elites empurrar seu próprio projeto de educação à nação. $\mathrm{O}$ projeto de Ribeiro apenas deu tempo para que elas se organizassem melhor e construíssem a sua "saída" educacional para o Brasil. Frigotto e Ciavatta (2003) analisam o processo depois de concluído:

A Lei de Diretrizes e Bases (Lei $\mathrm{n}^{\circ}$ 9.394/96), finalmente aprovada pelo Congresso, resultou da iniciativa personalista do senador Darcy Ribeiro e representou para Florestan Fernandes (1991) uma dupla traição: fez uma síntese deturpada do longo processo de negociação do projeto negociado com a sociedade organizada e deu ao governo, que não tinha projeto de LDB, o que este necessitava. Coerentemente, então, como evidencia Saviani, em minuciosa análise dos projetos de LDB em disputa, deveria ser uma LDB minimalista e, portanto, em consonância com a proposta de desregulamentação, de descentralização e de privatização [...]. (FRIGOTTO; CIAVATTA, 2003, p. 110).

$\mathrm{Na}$ verdade, a publicação de uma LDB forjada na ideia de um Estado minimalista dava a condição de futuramente se construírem todas as ações que fossem do agrado dos seus dirigentes. Dentre elas destaca-se o caráter consultivo do Conselho Nacional de Educação (CNE) na elaboração de políticas educacionais. Há de se mencionar o desastre representado pela edição do primeiro Plano Nacional de Educação (PNE) no pós-ditadura: em total desrespeito à organização dos trabalhadores e militantes da área, que já haviam construído antecipadamente ao governo suas propostas de valorização da educação para uma década (Plano Nacional da Educação da Sociedade Brasileira), a bancada do Presidente Fernando Henrique Cardoso forjou, de maneira quase instantânea, um PNE que veio a ser o vitorioso com promulgação em 2001. Esse plano caracteriza-se por ser:

Orientado pelo centralismo de decisões, da formulação e da gestão da política educacional, principalmente na esfera federal. Pauta-se pelo progressivo abandono, por parte do Estado, das tarefas de manutenção e 
desenvolvimento do ensino, por meio de mecanismos de envolvimento de pais, organizações não governamentais, empresas e de apelos à "solidariedade" das comunidades onde se situam as escolas e os problemas. $\mathrm{O}$ que resultou em parâmetros privatistas para o funcionamento dos sistemas de ensino. (FRIGOTTO; CIAVATTA, 2003, p. 113).

Nenhuma política social mais ou menos favorável aos trabalhadores é construída sem embates, sobretudo com o capital. O furor que envolveu os setores do polo capitalista em torno de uma LDB e de um PNE impopulares já estava sendo forjado bem antes da publicação de ambos. Sobre isso Silva (2005) afirma que:

O Governo Federal, entre 1990 e 2002, tornou-se sujeito ímpar no processo de ajuste e implementação de políticas sociais de corte neoliberal, na medida em que alterou a Constituição Federal de 1988, por meio de emendas e leis infraconstitucionais, além de medidas provisórias (MP). Portanto, ao subscrever os acordos internacionais com FMI e Banco Mundial, exigiu que o governo, no plano interno, instituísse preceitos jurídicos e normativos que reconfigurassem a ordem econômica e social do país. (SILVA, 2005, p. 258).

Não é de se estranhar que o projeto de educação das elites tenha sido vitorioso. Estava fundamentado no que havia de mais contemporâneo e considerado mais moderno (e ajuizado) pelas autoridades do FMI e BM para diferentes países. Como detalha Silva:

O Banco Mundial, como articulador financeiro internacional, organiza conferências cujo objetivo é estabelecer as diretrizes para a educação mundial e condiciona a aquisição de novos empréstimos financeiros a essas transformações na política educacional. As políticas educacionais formuladas pelo BM instituem a descentralização e a lógica gerencial para a organização das escolas, o foco na redução da pobreza e da miséria, a avaliação da aprendizagem e a inversão em capital humano. (SILVA, 2007, p. 265).

A materialização dos interesses do FMI e do BM chega até a sala de aula quando do cumprimento daquilo que está previsto nos Parâmetros Curriculares Nacionais (PCN). Se o currículo não é neutro, aqui há uma condição que torna óbvio o seu grau de compromisso com interesses da elite mundial:

A gênese constitutiva dos parâmetros curriculares nacionais está intimamente relacionada ao processo de implementação de políticas educacionais que visam a reformular o sistema educacional dos países em desenvolvimento, tendo como pressuposto o atendimento das exigências do processo de globalização e de desenvolvimento do projeto neoliberal no Brasil [...] especialmente a partir dos anos de 1990 com o início do governo Collor, e mais enfaticamente no governo de FHC. (RODRIGUES, 2002, p. 136). 
Dessa maneira, a expectativa de que os conteúdos ministrados em sala de aula ofereçam possibilidades de transcender à ordem da política educacional em curso deve ser menos otimista, afinal, os Parâmetros Curriculares:

Propõem a formação para o trabalho, para o mercado de trabalho, para a cidadania, para o imediato, desenvolvendo as habilidades (competências), transferindo para o plano subliminar ideias mais relacionadas a um fazer, a um agir e menos ao pensar, ao refletir. (SANTOS; MESQUIDA, 2007, p. 107).

A interferência do Banco Mundial na educação dos países em desenvolvimento vem sendo danosa. Libâneo (2012) afirma que há mais de 30 anos a escola brasileira vem vivendo um declínio em função dessa mediação, uma vez que o dualismo também está colocado para a nossa realidade educacional.

O dualismo está representado pela situação de que "num extremo, estaria a escola assentada no conhecimento, na aprendizagem e nas tecnologias, para os filhos dos ricos e, em outro, a escola do acolhimento social, da integração social, para os pobres, voltada primordialmente para missões sociais de assistência e apoio às crianças”. (LIBÂNEO, 2012, p. 16). Assim, o que caracteriza a escola para os pobres é a utilização de bases pedagógicas humanistas, como revestimento para critérios econômicos. Libâneo (Idem) entende que se idealizou uma escola que abarca e respeita desde as diferenças nos campos social e cultural até as diferenças de cunho psicológico de ritmo de aprendizagem, resultando em uma prática de avaliação escolar flexibilizada, sendo todas essas providências efetivadas em nome da educação inclusiva. Como ressalta o autor:

Não que esses aspectos não devessem ser considerados, o problema está na distorção dos objetivos da escola. Ou seja, "sociabilizar" passa a ter apenas o sentido de convivência, de compartilhamento cultural, de práticas de valores sociais, em detrimento do acesso à cultura e à ciência acumulados pela humanidade. O termo igualdade (direitos iguais para todos) é substituído pelo de equidade (direitos subordinados à diferença). (LIBÂNEO, 2010, p. 10).

Essa reflexão aponta-nos que a escola que restou aos pobres vem assumindo as missões assistencial e acolhedora, vindo a abraçar um arremedo de inclusão, de modo que a substituição da escola de formação cultural e científica pela escola do acolhimento social ocasiona perdas.

Ocorre o ocultamento da dimensão cultural e humana da educação, à medida que se dissolve a relação entre o direito das crianças e jovens de serem diferentes culturalmente e, ao mesmo tempo, semelhantes (iguais) em termos de dignidade e reconhecimento humano. (LIBÂNEO, 2010, p. 10). 
Ao comentar o resultado de toda essa concepção de escola, de feições aparentemente humanistas, o mesmo autor aponta o aparecimento de vítimas:

São os alunos, os pobres, as famílias marginalizadas, os professores. O que há à sua disposição é uma escola sem conteúdo e com um arremedo de acolhimento social e socialização (ampliada agora, em dois turnos, a escola de tempo integral!). O que apareceu como "novo padrão de qualidade" virou um arremedo de qualidade. A divulgação dos dados quantitativos apenas esconde mecanismos internos de exclusão ao longo do processo de escolarização. (LIBÂNEO, 2010, p. 10).

Dessa maneira, o autor aborda mais amiúde o impacto de políticas que são pensadas fora do país e incorporadas em nome de uma pretensa inclusão, que repercute severamente nos fazeres escolares, rebaixando-os à condição de acolher, desprezando as funções de partilha do conhecimento universalmente acumulado em nome de uma escolarização que cumpre o papel de servir aos interesses corporativos de uma reestruturação capitalista, que não requer massas com apropriação de conteúdos científicos e culturais. Isso ficaria para a escola dos ricos.

Se o alunado brasileiro fica refém de um quadro de atrelamento de interesses do FMI e BM à execução da educação pública, não menos preso fica aos interesses da classe capitalista brasileira. Segundo Saes (2005):

A classe capitalista tende, no terreno da educação das classes trabalhadoras, a defender as iniciativas filantrópicas privadas (como as escolas primárias geridas pelas próprias indústrias no início do capitalismo ou os programas empresariais de alfabetização de adultos) e a resistir (de modo mais ou menos explícito, conforme a conjuntura) ao cumprimento do princípio, imposto por alguma outra força social, da educação elementar obrigatória e gratuita. (SAES, 2005, p. 99).

Em outra direção, uma reflexão importante diante desse interesse das classes capitalistas em resistirem à oferta de uma educação gratuita e obrigatória é tentar entender como as distintas frações da classe trabalhadora entendem o acesso à educação. Conforme Saes (2005), a defesa pela classe média do ensino elementar público, obrigatório e gratuito não ocorre por ela entender que a oferta de serviços educacionais se reverterá em uma boa educação elementar para sua prole. A vida estudantil dos filhos da classe média realiza-se sem que o Estado precise pressioná-la para enviá-los à escola:

$\mathrm{Na}$ verdade, a classe média é a única classe social cujos membros consideram que a reprodução de sua situação econômica e social através dos filhos depende essencialmente da educação escolar, pois é esta que permite no mínimo, à geração seguinte, manter a condição de trabalhadores não manuais, superiores, dentro da hierarquia do trabalho, aos trabalhadores manuais. O ensino não precisa, portanto, ser obrigatório para que os pais de 
classe média levem os seus filhos à escola elementar; eles o fazem espontaneamente, pois a escola tem um papel central na própria reprodução de uma classe social definida pelo desempenho de trabalho predominantemente não manual. (SAES, 2005, p. 102).

Por outro lado, as classes trabalhadoras manuais enxergam na escola obrigatória um impedimento para que seus filhos se constituam em mais braços para garantir a renda familiar. Assim:

Analisada por esse ângulo, a entrada das crianças no ensino fundamental representa um desvio de energia que poderia ser empregada na esfera do trabalho e, portanto, indiretamente, um empobrecimento da família trabalhadora. Isso explica, de resto, que a evasão escolar das crianças pobres, como consequência do fracasso escolar, seja frequentemente encarada como uma fatalidade, e não como um acontecimento revoltante, pelos pais desses alunos. (SAES, 2005, p. 99).

Conclui-se que a ideia de uma escola pública elementar obrigatória impacta de maneiras distintas as classes sociais. As classes médias vêm se empenhando em pagar pelo ensino privado, quando se verificam pressionadas por uma avaliação ruim do ensino elementar ministrado em escola pública, mesmo que a escola particular selecionada não seja considerada de primeira linha, por terem mensalidades mais condizentes com as famílias de classes altas.

Aquelas famílias que não podem partir para uma solução de mercado frente ao sucateamento da escola pública, expressado em baixos índices nas avaliações institucionais Índice de Desenvolvimento da Educação Básica (Ideb), no caso do ensino fundamental -, na falta de equipamento e manutenção do patrimônio escolar, entre outros aspectos, cabe matricular seus filhos em uma escola que tem cedido espaços para outras provisões que não somente o ensino, perdendo a dimensão dele. Ou, como coloca Algebaile (2009), quanto mais a escola se torna robusta, alvo de diferentes programas sociais, sendo o Programa Bolsa Família (PBF) o mais emblemático, menos cumpre a sua tarefa precípua, que é ensinar.

A escola pública como "Estado dos pobres", no Brasil, assiste a uma ilimitada expansão que não colaborou para que ela se tornasse insurgente, com projetos mais criativos e ousados frente ao sistema em que está inserida. A escola foi ampliada para menos. Conforme Algebaile (2009), essa expansão concorreu para tornar a escola:

Mais permeável a novas e reiteradas utilizações privadas e instrumentais, empobrecedoras. Suas ampliações foram feitas à custa de encurtamentos, e não só da educação, mas também na esfera mais ampla da política social, [...] parte importante da desqualificação da escola está vinculada à sua utilização para finalidades não limitadas ao campo educacional escolar. [...]. A presença da escola em lugares "marcados por ausências" conferiu a essa 
instituição um sentido estratégico excepcionalmente amplo. (ALGEBAILE, 2009, p. 328).

A importância de estudos que mencionam a pobreza dos alunos e a pobreza da escola, relacionando-as com uma visão macroestrutural, reside no esforço de não isolar a escola dos determinantes que estão além dela. Ou melhor, daquilo que denominamos de leis tendenciais históricas ou de universalidades, das quais a escola não escapa, tendo em vista que não foi concebida para emancipar os filhos da classe trabalhadora. Tampouco precisa ser, em um país de economia dependente, universalmente de boa qualidade. O projeto capitalista em curso não ambiciona que todas as escolas sejam de qualidade, somente aquelas que cumprirão seus desígnios na produção. O fracasso escolar, nesse contexto, finda por ser visto como responsabilidade de alunos, de suas famílias pouco atentas e negligentes ou dos professores, desfocando o papel das altas esferas do Estado em sua construção.

Vale acrescentar que nesse cenário caótico erguido em lugares "marcados pela ausência” e em situações de grave desigualdade social, a escola pauperizada e tangenciada largamente pelo insucesso acaba sendo um espaço de eclosão de problemas de toda ordem, despotencializando suas funções precípuas. É preciso que pensemos que todo o cenário de globalização da economia, somado ao encurtamento dos papéis do Estado, impacta as pessoas dentro das instituições, trazendo inúmeras repercussões, sendo a violência uma delas. Situação que agrava ainda mais a estada de crianças pobres em ambiente escolar. Sobre isso, concordamos com Libório (2004) ao afirmar que:

A mundialização da economia pode influenciar na vida diária, nas relações que se estabelecem entre as pessoas seja na esfera familiar, assim como nas relações interpessoais dentro das demais instituições, tais como a escola, abrigos, aparato policial, etc.; tal influência se dá na medida em que os processos sociais gerados a partir da globalização da economia contribuem para a geração de pressão e tensões, que afetam os modos de vida em grande parte da sociedade, que passam a estar marcados por um contexto maior de violência. (LIBÓRIO, 2004, p. 30).

Dessa maneira, a permanência na escola, principalmente para as crianças pobres, não diz respeito somente à persistência dos pais ou ao empenho de seus profissionais, mas a um conjunto de fatores que escapam às disposições meramente subjetivas que ultrapassam os muros onde ela está inserida. Significa que o acesso à escola não é o bastante, "é preciso afiançar condições para a presença com qualidade dos alunos: construir o acesso ao transporte escolar, alimentação, material didático, uniforme, desmercadorizando as condições que permitem a frequência e o aproveitamento". (YANNOULAS, 2013, p. 54). Desta maneira, 
pode-se construir a permanência escolar qualificada, aquela que garante a aprendizagem, realidade ainda distante para a grande maioria do alunado da educação básica.

2.5.1.3 Ajustando o foco: agentes internos e externos da viabilização da permanência escolar com qualidade

Não é fator desprezível mencionar que, dentre todos aqueles que matriculam seus filhos na escola pública, somente alguns têm mais chance de obter sucesso nela. São exatamente os filhos das classes médias, uma vez que o espaço escolar, suas exigências, tarefas e cotidianos não se distanciam do universo delas. Apoiando-se em muitos pesquisadores, Saes (2008) expõe um paradoxo ao constatar que, ao mesmo tempo em que houve nos últimos 20 anos um significativo aumento do acesso à escola pública via ampliação de vagas no ensino fundamental e médio:

A democratização do acesso ao ensino fundamental não resultou numa
alteração qualitativa da configuração da pirâmide educacional brasileira.
Alunos ditos "pobres" - isto é, oriundos das classes trabalhadoras manuais -
estão relegados a uma trajetória escolar curta, que inclui a conclusão do
ensino fundamental ou, no máximo, do ensino técnico de nível médio. Já os
alunos ditos "ricos" (classe média-média ou classe média-alta, classes
proprietárias) conseguem cumprir uma trajetória escolar longa, que abrange
o ensino médio e o ensino superior (e, nos dias que correm, não só a
graduação como também, cada vez mais, a pós-graduação). (SAES, 2008,
p. 166).

Diante da preocupação em proporcionar aos filhos das classes populares a citada trajetória longa, que é alcançada pelos mais bem aquinhoados por seus capitais diversos (BOURDIEU, 1997), a pesquisa Lenskij (2006) traz alguns elementos para pensar permanência escolar a partir dos feitos das escolas para esse fim. Em sua pesquisa de campo, a autora examinou que o direito à permanência escolar de alunos da rede pública passava por três caminhos: 1) a prevenção da infrequência - realizada, entre outros fatores, por meio da adoção de programas sociais na escola, da gestão escolar ou do uso de adequadas metodologias de aprendizagem; 2) o resgate dos alunos infrequentes - realizada por meio de uma ação conjunta entre escola, Conselho Escolar, Conselho Tutelar e Ministério Público, que, apesar de inúmeros atropelos, colhia resultados esperados e; 3) o acolhimento dos retornados, onde a autora traz, em nossa perspectiva, seus achados mais importantes: que não há ainda estratégia específica para o recebimento dos alunos retornados à escola e que a negligência, a omissão e a violação do direito à permanência na escola são práticas de todos 
os agentes que têm compromisso em garantir direitos, questões essas que podem iluminar a nossa análise em suas especificidades.

A tentativa de acessar dados mais consistentes sobre a trajetória das crianças acolhidas e sobre o seu acesso à escolarização levou-nos a conhecer pesquisas, nem sempre muito detalhadas frente a esses aspectos, realizadas em âmbito nacional e local. A seguir citaremos algumas delas. A leitura do documento "O direito à convivência familiar e comunitária: os abrigos para crianças e adolescentes no Brasil”, publicado em 2004 sob a coordenação de Enid Rocha Silva, do Instituto de Pesquisa Econômica Aplicada (Ipea), dispõe os seguintes dados: 60,8\% dos abrigados de 0 a 6 anos frequentavam creches ou pré-escolas e 95,9\% dos que tinham entre 7 e 18 anos também estavam na escola.

Ainda segundo o citado documento, "Entre os principais motivos do abrigamento das crianças e dos adolescentes pesquisados estão: a carência de recursos materiais da família $(24,1 \%)$; o abandono pelos pais ou responsáveis (18,8\%); a violência doméstica (11,6\%); a dependência química de pais ou responsáveis (11,3\%); a vivência de rua (7,0\%); a orfandade $(5,2 \%)$; a prisão dos pais ou responsáveis (3,5\%); e o abuso sexual praticado pelos pais ou responsáveis (3,3\%)". (SILVA, 2004, p. 55). Esses números apontam os efeitos da desigualdade social como grande fator de acolhimento de crianças e adolescentes, seguindo-se a ela motivações que a tangenciam largamente na realidade brasileira, como vivência de rua, abandono pelos pais ou a prisão deles ou dos responsáveis.

Dados mais recentes, de 2010, de pesquisa feita pela Fundação Oswaldo Cruz (Fiocruz) $^{28}$, encomendada pelo MDS, apontam que 37,6\% das crianças e adolescentes acolhidos tiveram como motivação para a medida protetiva a negligência por parte de seus responsáveis ou pais, 20,1\% por terem pais dependentes químicos ou alcoolistas e 19\% por abandono. Contemporaneamente ao levantamento da Diretoria de Estudos Sociais (Disoc) do Ipea, o Núcleo de Estudos e Pesquisas sobre a Criança e o Adolescente da PUC de São Paulo, a Prefeitura de São Paulo (gestão Marta Suplicy 2001/2004), a Fundação Orsa e a Associação dos Assistentes Sociais e Psicólogos do Tribunal de Justiça do Estado de São Paulo realizaram uma pesquisa com o intuito de verificar a qualidade dos abrigos em São Paulo capital. O estudo apontou o seguinte quadro de escolarização:

\footnotetext{
${ }^{28}$ Publicada sob o nome de "Levantamento Nacional das Crianças e Adolescentes em Serviço de Acolhimento". ASSIS, Simone G.; FARIAS, Luís O. (Orgs.). São Paulo: Hucitec, 2013. Doravante, quando houver referência à pesquisa Fiocruz, trata-se desse levantamento.
} 
A maioria das crianças e adolescentes em fase de escolaridade obrigatória (77\%) está inserida na rede escolar. As justificativas para aqueles que não estão matriculados referem-se em sua maioria aos portadores de deficiência mental sem condições de aprendizagem e ainda àqueles para os quais não se obteve vaga em escola ou classe especiais. Há ainda os que foram abrigados no final do período letivo, não sendo possível matriculá-los. ${ }^{29}$

Os dados obtidos especificamente junto aos adolescentes não foram promissores, uma vez que sinalizam problemas quanto à sua autonomia quando do desligamento do abrigo. Daqueles entre 15 e 18 anos:

Apenas $20 \%$ cursam o ensino médio. A maioria (52\%) cursa o ensino fundamental $\left(4^{\mathrm{a}}\right.$ a $8^{\mathrm{a}}$ série), existindo ainda uma pequena parcela (11\%) no ensino fundamental ( $1^{\mathrm{a}}$ a $4^{\mathrm{a}}$ série), questão essa que revela a defasagem no grau de escolaridade daqueles que estão prestes a serem desabrigados. Em 17\%, não foi registrada tal informação. (IDEM, p. 173).

No Distrito Federal, local de nosso trabalho de campo, naquilo que se refere à sua escolarização, crianças e adolescentes em acolhimento institucional aparecem em pesquisa constitutiva do Plano Distrital de Promoção, Proteção e Defesa do Direito de Crianças e Adolescentes à Convivência Familiar e Comunitária (PDCFC) na seguinte conformação: 28\% estavam entre a $1^{\mathrm{a}}$ e a $4^{\mathrm{a}}$ série, $15 \%$ entre a $5^{\mathrm{a}}$ e a $8^{\mathrm{a}}$ série. Assim, estudantes abrigados cursando o ensino fundamental estão na casa dos $43 \%$.

Não há informações suficientes para se avaliar a correlação entre idade e nível de escolaridade. Pode-se, contudo, afirmar em relação aos adolescentes que frequentam o ensino médio ( $2 \%$ possuem ensino médio incompleto e $1 \%$ completo) que o percentual é extremamente baixo e preocupante, quando se sabe que $18 \%$ dos abrigados se encontram na faixa etária entre 16 e 21 anos. (GDF, p. 84).

Sobre esses números, existe no mesmo plano a seguinte constatação sobre o segmento de adolescentes, que:

Além de ter baixa escolaridade, não possui, em sua maioria, qualificação profissional para a inserção no mercado de trabalho, podendo ter reflexos significativos na sua sobrevivência e no exercício de seus direitos e deveres como cidadão. (idem, ibidem).

No documento Orientações Técnicas para os Serviços de Acolhimento de Crianças e Adolescentes, que se constitui em uma resolução do Conanda e CNAS, datada de 2009, está afirmada como fundamental a articulação dos serviços de acolhimento com o sistema educacional, endossando-se que:

\footnotetext{
${ }^{29}$ Por uma política de abrigos em defesa de direitos das crianças e dos adolescentes na cidade de São Paulo: motivos de demanda e qualidade de oferta de serviços de atenção à criança e ao adolescente sob medida de proteção "abrigo" (p. 172).
} 
Essa articulação pode ser feita por meio da elaboração conjunta de protocolo de ação entre o órgão gestor da Assistência Social e da Educação, garantindo a permanente comunicação entre os serviços e o acesso das crianças, adolescentes acolhidos e seus familiares à rede local de Educação. (OTSACA, 2009, p. 46).

Diante do exposto, é fundamental saber como o atendimento escolar das crianças vem sendo propiciado pelas instituições escolares e como a unidade de acolhimento vem sendo coadjuvante nesse esforço articulado. Não se trata apenas de verificar o acesso à escolarização, mas também de compreender como ocorre a permanência dessas crianças na escola, no sentido estrito da aprendizagem. No mesmo documento também há uma preocupação com a formação dos profissionais das unidades de acolhimento no que concerne aos seus papéis na tarefa educativa:

$\mathrm{O}$ reconhecimento de que todos os profissionais que atuam em serviços de acolhimento desempenham o papel de educador impõe a necessidade de seleção, capacitação e acompanhamento de todos aqueles responsáveis pelo cuidado direto e cotidiano das crianças e adolescentes acolhidos. (OTSACA, 2009, p. 61).

Como se vê, os setores organizados, governos e conselhos conseguiram empenhar esforços a fim de formular orientações técnicas que conferissem ao espaço de acolhimento uma quebra com o padrão asilar, o que não quer dizer por si só que isso o tenha tornado mais educativo ou promissor para a escolarização. Passados cinco anos da publicação das Orientações Técnicas: Serviços de Acolhimento para Crianças e Adolescentes, é preciso que analisemos se mudanças foram verificadas, visando a garantir que o direito à educação seja efetivado com uma permanência escolar proveitosa para esse público, entendendo, como já foi dito, que esta última ultrapassa a mera frequência diária por parte dos alunos, passando pela compreensão do conjunto da escola sobre o teor da medida protetiva. Em face do exposto, procuraremos examinar com maior detalhe a política de acolhimento no contexto da Assistência Social.

\subsubsection{A Política de Assistência Social e o acolhimento de crianças e adolescentes}

A Assistência Social conquistou um grande avanço no texto constitucional, tendo em vista que antes de 1988, ou seja, mesmo após 100 anos de República, ela não havia se verificado como direito do cidadão e tampouco como dever do Estado. A Assistência Social existe no país desde o Brasil Colônia, embora fosse movida por fatores religiosos, 
sentimentos de compaixão, por interesses eleitoreiros e mesmo como moeda de troca, o que remete a uma perversão de seu papel crítico no trato da "questão social".

Os grupos humanos, bem antes da modernidade, praticavam atos de solidariedade com os mais fragilizados ou mesmo com os severamente prejudicados por doenças, intempéries climáticas, deficiências físicas e outras mazelas. A assistência veio tomando distintas feições no decorrer do tempo. De mera ajuda mútua presente em distintas civilizações, pode ser vista também como efeito de dominação, a exemplo das Poor Laws, instituídas na Inglaterra em três séculos de industrialização, que mais achincalhavam os pobres do que lhes ofereciam proteção contra a selvageria do capitalismo. No Brasil, a Assistência Social "foi concebida historicamente como caridade, numa perspectiva clientelista, desenvolvida por meio de ações focalistas e emergenciais, baseada numa relação de favor, de troca clientelista”. (LAJÚS, 2010, p. 21). No Brasil de hoje, ela está situada no arco de políticas que compõem a Seguridade Social, sendo regida pela Loas. Foi uma política concebida pelos profissionais militantes da Assistência de modo a transcender a mera distribuição de benefícios e serviços, devendo funcionar articuladamente com outras políticas públicas, não focalizando ações em situações de pobreza extrema, uma vez que é entendida como direito universal.

Assim, a política de Assistência Social no período de "redemocratização" foi pensada de maneira a se articular com outras políticas sociais, constituindo um:

Sistema de proteção social que deve ser contínuo, sistemático, planejado, articulado, com recursos garantidos no orçamento público das três esferas governamentais, com ações complementares entre si, evitando o paralelismo, a fragmentação e a dispersão de recursos. O horizonte da Assistência Social não pode levar esta política a esgotar-se em si mesma. (BOSCHETTI; TEIXEIRA, p. 3).

A Assistência Social viabiliza-se institucionalmente como política social dentro da Secretaria Nacional de Assistência Social, pertencente ao MDS, responsável pela elaboração da Política Nacional de Assistência Social (PNAS) do ano de 2004. É esta política que prevê e define o Sistema Único de Assistência Social (Suas), conforme o disposto como recomendação na IV Conferência Nacional de Assistência Social, ocorrida em 2003 na Capital federal. Como definem o Conanda e o CNAS (2008), o atual acolhimento para crianças e adolescentes deve ter como suporte as formulações pelas quais se pauta o Suas. Esses serviços pertencem à Proteção Social Especial (PSE), prevista em sua organização: 
Os serviços de acolhimento para crianças e adolescentes integram os Serviços de Alta Complexidade do Sistema Único de Assistência Social, sejam eles de natureza público-estatal ou não estatal, e devem pautar-se nos referenciais dos seguintes documentos: Estatuto da Criança e do Adolescente, Plano Nacional de Promoção, Proteção e Defesa do Direito de Crianças e Adolescentes à Convivência Familiar e Comunitária, Política Nacional de Assistência Social e Projeto de Diretrizes das Nações Unidas sobre Emprego e Condições Adequadas de Cuidados Alternativos com Crianças. (BRASIL, 2008, p. 2).

Há, em nossos dias, uma oferta predominante de serviço de acolhimento por uma rede socioassistencial privada, conveniada ou não com os governos. Esses serviços tiveram como marca inaugural a inserção da Igreja Católica, sendo que somente em 1922 surge o primeiro estabelecimento público para o atendimento de crianças e adolescentes na cidade do Rio de Janeiro. (SILVA; MELLO, 2004). Desse fato é possível se depreender que a "questão social" que diz respeito ao abandono de crianças e adolescentes ou a retirada do poder familiar de seus responsáveis não é assistida exclusivamente na esfera do serviço público $(41,9 \%)$, mas majoritariamente no âmbito de uma rede privada ${ }^{30}(58,1 \%)$, que, combinada ao recrudescimento do voluntariado, reduz o papel que deveria ser somente do Estado no que concerne à garantia de proteção, dentro do arco da seguridade social. Atualmente, cerca de $41,9 \%$ dos estabelecimentos privados que fazem o acolhimento no país são de confissão católica.

Existem hoje no país, segundo o Cadastro Nacional de Crianças Acolhidas (CNCA), 45.237 crianças e adolescentes vivendo em abrigos. O número do CNCA não coincide com o apresentado pela Secretaria Nacional de Assistência Social. Por exemplo, nos dados do Censo do Sistema Único da Assistência Social (SUAS) de 2012, utilizados pelo MDS, existiam 2.380 abrigos no país e 33.456 crianças e adolescentes em acolhimento. Já nos dados do Cadastro Nacional de Crianças e Adolescentes Acolhidos (CNCA), do CNJ, eram contabilizadas 4.029 entidades de acolhimento e 43.585 acolhidos. Em razão disso, representantes da Corregedoria Nacional de Justiça, do Conselho Nacional do Ministério Público (CNMP) e da Secretaria Nacional de Assistência Social do Ministério do Desenvolvimento Social e Combate à Fome (MDS) têm buscado a unificação das bases de dados sobre os abrigos para crianças e adolescentes existentes no país. Durante o ano de 2013,

\footnotetext{
${ }^{30}$ Os percentuais apresentados no parágrafo estão em conformidade com os dados do "Levantamento Nacional das Crianças e Adolescentes em Serviços de Acolhimento", realizado pela Fiocruz. Importa acrescentar que, dentre as entidades de acolhimento governamentais, 9\% são estaduais e 90,1\% são municipais ou do Distrito Federal. E que, 41,9\% dos SAI são governamentais e 58,1\% são não governamentais.
} 
o Distrito Federal possuía um número de cerca de 403 crianças e adolescentes em acolhimento institucional.

Como já foi dito, a institucionalização para crianças e adolescentes tem um grande vínculo histórico com o assistencialismo, com a caridade e a filantropia, marca ainda não superada. Mesmo o acolhimento institucional, amparado por legislação e por Políticas de Assistência Social, vive sob um quadro de precariedades substantivas: falta pessoal qualificado nas instituições, atendimento personalizado às crianças e adolescentes que têm trajetórias distintas, além de uma organização que permita a construção de um projeto político-pedagógico para orientar todos os trabalhos que se desempenham na tarefa do acolhimento $^{31}$. Tal contexto leva-nos a crer que o atendimento dos acolhidos não tem consonância com o Sistema de Garantia de Direitos em sua integridade, exigindo mais lutas e pressão de todas as partes para a concretização de direitos, posto que se destina a pessoas em desenvolvimento e em idade escolar.

A Assistência Social vem construindo políticas bastante distanciadas dos propósitos que lhes deram origem na Carta Constitucional, particularmente a partir do governo FHC. Desde então, viu-se imergindo no binômio seletividade e focalização, que desqualifica e deturpa uma proteção abrangente e universalista. Nenhuma falha nos serviços de acolhimento pode ser avaliada sem relacionar esses fatores, direta ou indiretamente. Boschetti e Teixeira (2004) afirmam que, no decorrer de 10 anos de Loas:

O princípio da universalidade foi desrespeitado e subjugado pela política neoliberal que priorizou os ajustes fiscais e políticas monetaristas (ANDERSON, 1995; NAVARRO, 1998; SOARES, 1999) em detrimento de investimentos sociais. As restrições que foram impostas à extensão da política assistencial e à materialização de suas diretivas encontram solidez na política econômica desenvolvida ao longo da década de 1990, que, aprisionada pelos ditames do ajuste estrutural receitado pelo Banco Mundial e FMI (SOARES, 1999), orientam-se pela rentabilidade econômica e não pelas necessidades sociais (PEREIRA, 1996). (BOSCHETTI; TEIXEIRA, 2004, p. 3).

As críticas continuaram tendo razões para existir. O governo do Presidente Lula concebeu o Programa Bolsa Família como a prioridade e como a "cereja do bolo" de sua política de Assistência Social, quando, em países desenvolvidos, a transferência de renda costuma ser o último dos recursos destináveis às famílias. Dessa maneira, vivemos um esvaziamento da proposta de programas e serviços contínuos de Assistência Social voltados

\footnotetext{
${ }^{31}$ Em conformidade com os dados do "Levantamento Nacional das Crianças e Adolescentes em Serviços de Acolhimento".
} 
para os núcleos familiares. Conforme relatório da Anfip sobre os gastos da seguridade social em 2010:

Os programas de transferência de renda - Benefício de Prestação Continuada e Programa Bolsa Família - totalizaram um gasto de aproximadamente 35 bilhões. Os demais programas, integrantes do Sistema Único da Assistência Social (Suas), tiveram um total de gastos avaliado em pouco mais de 2 bilhões. Essa lógica permanece, também, no governo atual. A ênfase nos programas de transferência de renda e, em especial, no Programa Bolsa Família como a grande operação de combate à pobreza no Brasil está presente nas ações do governo Dilma. (MOURA, 2011, p. 20).

Este cenário torna a preocupação com a qualidade dos serviços de acolhimento mais afirmada, uma vez que não são vistos na mesma dimensão que um PBF. Mesmo frente a essa problemática, está em curso hoje toda uma mobilização da política de Assistência Social com vistas à expansão qualificada ou reordenamento dos Serviços de Acolhimento, no formato institucional e familiar, voltados para crianças, adolescentes e jovens de até 21 anos de idade no âmbito dos municípios e Distrito Federal.

A expansão qualificada vem a ser a implantação de novos Serviços de Acolhimento, de acordo com o estabelecido pelas Otsaca e legislação em vigor. O reordenamento constitui-se no processo gradativo que envolve a gestão, as unidades de oferta do serviço e os usuários, visando à qualificação da rede de Serviços de Acolhimento existentes, em conformidade legal.

É importante dizer que a possibilidade da existência de unidades de acolhimento menores, como casas-lares nas comunidades e as famílias acolhedoras, igualmente previstas na Otsaca, acena como possibilidade mais humanizadora na política de Assistência Social em andamento, mas elas também dependem de aportes governamentais. Para termos uma avaliação melhor dos recursos que mantêm as instituições, o anteriormente citado "Levantamento Nacional das Crianças e Adolescentes em Serviços de Acolhimento" informa que 49,7\% das unidades dos serviços de acolhimento institucional não governamentais recebem doações de pessoas físicas, de suas mantenedoras e de empresas privadas, o que as coloca em uma situação instável, bem como as crianças e adolescentes que abrigam. 


\subsubsection{A história do acolhimento social}

A partir do entendimento do papel fundamental que cabe à economia na compreensão da evolução histórica e também no erguimento da superestrutura em suas diversas expressões institucionais, procederemos a uma historicização das distintas maneiras como crianças de origem popular foram tratadas pela escola e pelas instituições que mantinham serviços de asilamento/assistência. É importante frisar este contexto, principalmente quando se viram em situações de abandono ou em trajetórias familiares pouco apreciáveis pelas autoridades constituídas em diferentes momentos da história brasileira, a partir do Período Colonial.

Conforme Faleiros, desde o Descobrimento do Brasil até a sua Independência, as leis e as ordens para as crianças "vinham de Portugal e eram aplicadas através da burocracia, dos representantes da Corte e da Igreja Católica". (FALEIROS, 2007, p. 17). Era um momento de aliança entre Estado e Igreja, em que operavam juntamente a conquista armada e a profissão da religião. Os padres impunham às crianças indígenas a religião cristã, após separá-las de suas comunidades originais. Ainda que os religiosos não aprovassem os castigos físicos nesse processo "educativo", agiam de maneira igualmente violenta ao forçar-lhes a assumir uma cultura que não lhes pertencia ancestralmente.

Em uma economia agroexportadora como a aqui implantada, também a vida das crianças negras escravizadas não se revestia de maior dignidade. Muitas morriam cedo. Até porque era mais vantajoso aos senhores proprietários comprar um escravo adulto vindo da África do que alimentá-las até a idade de poderem trabalhar na lavoura ou em qualquer outro serviço. Afinal, um escravo adulto estava pago em um ano de exploração de sua força de trabalho. As crianças solitárias, apartadas de suas mães, que se tornavam amas de leite, tinham pouca chance de sobrevivência caso não fossem diretamente cuidadas e preservadas de intempéries e perigos. As crianças que sobreviviam a essas condições eram colocadas precocemente para trabalhar.

É nesse quadro, que hoje interpretamos como graves violações à dignidade das crianças, que surge uma assistência caritativa, voltada fundamentalmente para aliviar o sofrimento dos desprovidos ou desfavorecidos conforme o pensamento cristão professado pela elite colonial. As Santas Casas de Misericórdia cumpriam relevante papel no sentido 
de assistir os "enjeitados" e nutriram-se do auxílio financeiro das Câmaras Municipais para tal feito.

Para que não pairem dúvidas sobre o tipo de atendimento caritativo oferecido pela citada irmandade, é preciso que se afirme que o seu objetivo não era educativo. Tampouco havia um planejamento que ordenasse os seus fazeres voltados para essas crianças. As Casas de Misericórdia funcionavam como uma espécie de casa de passagem, de onde se encaminhavam as crianças para outros destinos: de 0 a 3 anos, destinavam-se a amas de leite pagas. Uma vez não adotadas ou acolhidas depois de findos os três anos de idade, eram reencaminhadas à casa de assistência até completarem os 7 anos, idade em que poderiam ser expostas para trabalho escravo. Poderiam ainda ser levadas para o uso privado de uma família, também como força de trabalho auxiliar.

Outros sistemas que integravam a formalidade do atendimento junto às crianças abandonadas, resultante de convênios entre as municipalidades e a Santa Casa, eram: a $\operatorname{Roda}^{32}$, o mecanismo de recolhimento sigiloso de bebês; e o Recolhimento, destinado às meninas oriundas da pobreza. O papel desses serviços ofertados pela Santa Casa era moralizar as cidades coloniais, onde filhos oriundos da miscigenação expunham vexatoriamente os senhores proprietários em suas relações fora do casamento com mulheres não brancas, subalternizadas desde aquela época. As crianças abandonadas em idade maior eram encaminhadas ao trabalho.

Já em 1854 havia a intenção de recolher os meninos que vagavam pelas ruas, segundo um decreto imperial daquele mesmo ano. Mas só em 1871 foi criado o asilo de meninos desvalidos. As meninas desvalidas indigentes eram acolhidas na Santa Casa desde 1740. No final do século XIX, havia trinta asilos de órfãos, sete escolas industriais e de artífices e quatro escolas agrícolas. (FALEIROS, 2007, p. 20).

O trabalho também aparece como importante tarefa para as crianças no período denominado de assistência filantrópica. A Proclamação da República representa uma ruptura com a Igreja Católica, que não foi misericordiosa com os pobres, tampouco combateu a escravidão no país, afinal, "participou do processo de montagem e consolidação da sociedade colonial, de caráter patriarcal, autoritário e sem compromisso com a cidadania de todos”. (SALES, 2007, p. 53). Nesse cenário a (questionável) dimensão caritativa da

\footnotetext{
${ }^{32}$ Constituía-se de um cilindro giratório fixado à parede da Santa Casa, onde se depositavam os bebês abandonados, na expectativa de que fossem acolhidos. A primeira roda data de 1726 e foi construída na Bahia.
} 
assistência vai perdendo lugar para a filantropia. A iniciativa privada manterá os asilos para as crianças.

É um período de forte apelo do pensamento higienista, do cuidado extremado com as condições de limpeza e de assepsia nas instituições e nas famílias, o qual se fundamentava no conhecimento de médicos e engenheiros. A sujeira era associada a uma desqualificação moral, sobretudo quando encontrada entre os pobres. Na transição para o século XX, a internação permaneceu como recurso de salvação da criança desvalida, abandonada ou delinquente. "Crianças" passa a ser termo usado para os filhos abastados; e "menores", para os filhos da população carente, para os delinquentes, desfavorecidos e abandonados. As ideologias que sustentavam a internação são oriundas das ciências humanas e sociais. A proteção perde seu cunho caritativo e passa a viver a ambivalência de "defender, preservar do mal a criança e a sociedade". (ROSSETI-FERREIRA, 2011, p. 36).

A educação, nesse primeiro Período Republicano, quase em nada remetia a uma escolarização massiva. Havia até uma retórica em torno do papel da educação, "mas com um sentido particular - como antídoto à ociosidade e à criminalidade e não como instrumento que possibilitasse melhores chances de igualdade social”. (RIZZINI, 2011, p. 144).

É nesse contexto que o Estado constrói um atendimento em que, através do recolhimento ou da internação, busca recuperar crianças com destino à sociedade produtiva, materializando isso "por meio da instrução mínima e da formação profissional. A nova ideologia do trabalho, a partir da década de 1920, é expandida pelo judiciário, com a criação de uma legislação especial para a infância, dando origem ao Código de Menores (1927)". (JANZCURA, 2008, p. 115).

É no turbilhão de tensões de uma sociedade brasileira dirigida por elites desconectadas dos interesses do povo que o referido código é aprovado em 1927. Aquele foi um momento em que se creditou, pelas vias da ciência sem compromisso humanista, um fator hereditário às condutas antissociais, que seria potencializado pelo meio social, ou melhor, pela pobreza. Uma legislação desse teor acabaria por colocar infantes pobres em situações familiares atípicas, como pessoas necessariamente tangenciadas pela criminalidade. Para ilustrar a situação, a classificação e intervenção do Juizado de Menores sobre o chamado "menor" era inspirada no modelo de atuação das delegacias. 
No tocante à educação dos "menores" considerados perigosos à elevação do país à nação civilizada, é importante citar a experiência de Sergipe, que traduz o tratamento educacional dispensado a esse grupo à época. Em 1939, o governo sergipano, em parceria com o Governo Federal, autorizou a criação da Cidade de Menores Getúlio Vargas, com o intuito em cidadãos voltados para o progresso aspirado pelas elites. Como lembra Bispo (2004, p. 3), “A Cidade de Menores 'Getúlio Vargas', destinada às crianças abandonadas, oferecia apoio educacional e profissional ensinando técnicas agrícolas, com o objetivo de transformar os jovens". Ou seja, o Estado Novo varguista ainda tem a educação como veículo reformador de grupos indóceis, no sentido de encaminhá-los para o trabalho de remuneração parca e de direitos trabalhistas não assistidos.

Outra narrativa bastante cruel sobre o destino de meninos pobres institucionalizados, ainda na Era Vargas, é a do Educandário Romão de Mattos Duarte da Irmandade de Misericórdia do Rio de Janeiro - DF, do qual vários deles foram levados, sob promessas falsas, para fazendas em Campina do Monte Alegre, estado de São Paulo, tendo como avalista o Juizado de Menores do Distrito Federal. Aguilar (2011), que pesquisou esse momento da história educacional do país, entre 1930 e 1945, relata que essas crianças, como se dizia naquele momento:

Trabalharam, geraram riquezas sem serem empregadas nem receberem salários e foram castigadas com cárcere, violência física e constrangimentos morais. Foram escravizadas. Vestiram fardas integralistas sem a possibilidade de saber o que era o integralismo. Cuidaram de animais marcados pela suástica desconhecendo o nazismo, foram usadas economicamente e politicamente. (AGUILAR, 2011, p. 214).

Ao mesmo tempo em que argumenta que todas elas estavam sob a guarda do Estado, o autor afirma o absurdo de como a educação era tratada para os desprovidos de bens materiais e do convívio familiar:

"Educar a menoridade" apareceu como termo ligado sistematicamente a verbos como dirigir, controlar, disciplinar, treinar, testar, higienizar, militarizar, trabalhar, castigar e eugenizar. As crianças e os adolescentes por serem vistos como seres "inconscientes e inconsequentes" só tinham deveres e responsabilidades a cumprir, como se o Estado e a sociedade devessem se proteger preventivamente dos "menores órfãos e abandonados" e não garantir seus direitos. (Idem).

Em 1941, ainda durante o Estado Novo varguista, é criado o Serviço de Assistência ao Menor (SAM), visando a ministrar o tratamento aos menores que já fora de exclusividade dos juízes. O SAM não escapou às denúncias de maus-tratos aos menores e de corrupção interna. A estada no local significa um estigma para o interno. 
Dado o que foi exposto até aqui, o Brasil, em sua lenta inserção na industrialização, repetiu as mazelas e as atrocidades ocorridas no desenvolvimento do capitalismo em distintos países europeus no tocante ao tratamento de sua mão de obra, particularmente daquela recrutada antes da idade adulta. E tampouco conseguiu avançar em maiores cuidados naquilo que esses países alcançaram em seus enfrentamentos de classe, como proteção às mães, aos velhos, à infância. Às crianças ricas ou de extratos médios couberam os mimos, os cuidados e o aprendizado próprio à classe, procedimentos vistos como injunções para seus familiares. No entanto, às pobres restou o trabalho e/ou a institucionalização. Como verifica Sales (2007), desde os anos 1920 há um esforço do Estado em regular o trabalho do chamado menor, proibindo o trabalho noturno, mas ratificando-o, ainda assim, como destino da criança pobre. A mesma autora afirma que a primeira legislação, nesse sentido, vem de 1891 nos primeiros passos da República. Ou seja, as crianças e adolescentes de classes populares tinham no trabalho uma vinculação estreita com a sobrevivência, uma vez que as políticas sociais não existiam para dar-lhes sustentação e proteção.

Somente em 1979 o Código de 1927 foi revogado e em seu lugar construído outro que se adequou à necessidade de repressão demandada pelo Regime Militar, agora inspirado na Doutrina da Situação Irregular (DSI). É forçoso lembrar que a edição desse código ocorreu exatamente no ano de celebração de 20 anos da Declaração Internacional dos Direitos da Criança, não assumindo compromissos com ela, detendo-se apenas na regulamentação das chamadas situações irregulares.

Onze anos mais tarde, com a promulgação do ECA em 1990, é que a Doutrina da Situação Irregular (1979) veio a ter seus dias findos, após toda uma organização de setores ligados à luta pela infância. A década de 1980 foi bastante rica nesse sentido. Conforme Santos et alii (2010), a noção de criança como sujeito de direitos ${ }^{33}$ é inaugurada, rompendo-se com a ideia de que a infância não seria uma possibilidade para as crianças, particularmente as

\footnotetext{
${ }^{33}$ A categoria "sujeito de direitos" é construída dentro do capitalismo, no decorrer da modernidade. Inicialmente só o burguês era considerado um sujeito de direitos (séc. XIX). No entanto, quanto mais avançadas se tornam as relações dentro do capitalismo, mais elas prescindem de uma figura de mando, o que acaba por instaurar uma necessidade: para "que todos possam ser explorados, como corpos e inteligências que vendem seu trabalho, todos são sujeitos de direito, indistintamente. A exploração capitalista, assim, erige uma nova instância social como seu fundamento de repressão: o direito estatal. Se todos forem sujeitos de direito, todos podem transacionar no mercado, comprando e vendendo mercadorias e possibilitando a exploração do trabalho por meio do contrato assalariado. O capitalismo desloca a violência das mãos de cada senhor para as ditas mãos impessoais do Estado [...]. A igualdade formal entre os sujeitos de direito que são constituídos como objeto da exploração do trabalho pelo capital e a atuação do Estado nos limites da força prevista juridicamente, de modo impessoal, passam a ser o horizonte máximo da dignidade humana no capitalismo". (MASCARO, p. 20). É dentro dessa dignidade limitada e contraditória que as crianças e os adolescentes são colocados como sujeitos de direitos dentro da legislação brasileira.
} 
de meios pobres, estigmatizadas pelos setores conservadores como "menores". Como sintetiza Fonseca (2007), a partir de 1990 houve grandes avanços:

Quanto aos marcos jurídicos regulatórios no âmbito das políticas protetivas da infância e adolescência, fruto de uma ampla discussão acadêmica e jurídica em torno da defesa dos direitos fundamentais da pessoa e tendo como figura central o ser humano em formação, com necessidades peculiares a seu desenvolvimento físico, social e político. A criança e o adolescente passaram a ser conceituados enquanto sujeitos de direito em oposição a “objetos de proteção". (FONSECA, 2007, p. 80).

Nesse sentido, em função de todo um aporte crítico, a assistência promovida pelo Estado por meio da Funabem e pelas Febems é bastante questionada por amplos setores da sociedade, em razão das práticas institucionais pouco ou nada edificantes ao desenvolvimento de crianças e adolescentes.

Em 1985 nasce o Movimento Nacional de Meninos e Meninas de Rua, resultante indireto do projeto Alternativas Comunitárias de Atendimento a Meninos de Rua, implantado em 1982. Em 1988 o Fórum Nacional Permanente de Entidades não Governamentais de Defesa da Criança e do Adolescente é criado. O chamado fórum DCA torna-se então um dos maiores protagonistas em defesa da inclusão de direitos para crianças e adolescentes na Constituinte. A Carta Magna de 1988 é promulgada com dois artigos que tratam especificamente desses direitos. O Fórum DCA prossegue a luta pela criação do Estatuto da Criança e do Adolescente com a parceria mais ampla de entidades em rede em todo o território nacional, todas imbuídas em fazer valer o paradigma dos direitos das crianças e dos adolescentes. Até o ano de 1990 praticamente todo o Período Republicano foi de permanente vigilância sobre as condutas de crianças e adolescentes pobres no sentido de apartá-los socialmente, caso se mostrassem indóceis ou caso seus pais se mostrassem fora daquilo que se considerava a melhor conduta.

A promulgação do ECA em 13 de julho de 1990 veio para tentar quebrar esse projeto ideológico, trazendo novos olhares sobre crianças e adolescentes e suas famílias e sobre a maneira de protegê-los em uma convergência de distintas políticas sociais. A assistência à criança e ao adolescente deixa de ser uma obrigação setorial (de uma igreja ou de um filantropo), passando a ser intersetorial e voltada para o desenvolvimento integral de ambos. Emerge materializada a Doutrina da Proteção Integral, onde o direito à convivência familiar e comunitária deve ser resguardado, a fim de que não se incorra em mais segregação entre crianças e adolescentes pobres e seus familiares como no passado, mediante qualquer situação que se apresentasse como anormal aos olhos da justiça. A situação apontada pela pesquisa 
coordenada por Enid Silva (2004) afirma que a população de crianças e adolescentes acolhidos institucionalmente após a promulgação do ECA chega ao abrigo por determinações ligadas à pobreza, embora pela própria doutrina que move o ECA isso não devesse se constituir uma realidade.

As carências materiais sofridas pelas famílias de baixa renda impõem dificuldades adicionais para a sobrevivência do grupo, ampliando a possibilidade de crianças e adolescentes pobres passarem por períodos de institucionalização. Desta maneira, pode-se dizer que as condições sociais em que vive a população negra no Brasil são a principal causa da maior incidência delas nas instituições de abrigo pesquisadas no estudo citado. (SILVA, 2004, p. 54).

O grave quadro apresentado, que levaria um tempo considerável para ser sanado em um contexto de um Estado de Bem-Estar europeu, torna-se ainda mais severo mediante a aplicação precarizada do ECA em um período fortemente marcado pelo neoliberalismo, de extremas restrições ao que se delineia como social. De que maneira crianças e adolescentes seriam sujeitos de direitos em meio a políticas que negam o papel social do Estado? O contexto sociopolítico e econômico em que a pesquisa citada se realizou, no final do segundo mandato de Fernando Henrique Cardoso (1995-2003), mostrou o efeito perverso causado por medidas econômicas impopulares sobre as crianças e adolescentes, sobretudo aqueles que têm um longo histórico familiar de injustiças sociais e usurpações, tal como aqueles oriundos de antepassados escravizados que vivenciaram também uma história republicana privada de acessos a bens públicos. Um estatuto considerado tão avançado, visto como referência internacional, corria o risco de ser letra morta em um contexto em que o social perde terreno ininterruptamente para os interesses do capital.

A construção do presente capítulo veio para satisfazer a necessidade que o método aponta de uma base histórico-econômica, para entendermos o objeto sobre o qual nos debruçamos. O Brasil que temos hoje é produto de inúmeras vitórias e derrotas de suas classes trabalhadoras em luta contra as classes capitalistas. A escola pública, o ECA, a Assistência Social, entre outras conquistas sociais, resultam de um enfrentamento secular das classes trabalhadoras, vitimizadas pelas escolhas atrozes que as classes dominantes construíram para conduzir a nação, à custa de violência, ditaduras e golpes voltados àqueles que contra elas se insurgissem e denunciassem a condição subalterna do país. A luta por escola pública ainda não teve um ponto final no Brasil. Ela é um continuum de longa duração, que agrega muitas outras lutas dentro de si, pois não basta alcançá-la pela matrícula. A escola, como produto de 
políticas públicas, precisa estar municiada também para garantir a permanência escolar de grupos que lhe são estranhos, para que não se descaracterize como bem público. E a intersetorialidade acena como uma comunhão de esforços nesse sentido, com todas as contradições que possam advir de fazeres intersetoriais, haja vista que o Estado é setorializado e premido por interesses político-partidários que recusam a necessidade de integração de práticas e saberes na condução das políticas públicas, apesar de ser um consenso que elas devam existir. (ANDRADE, 2006)

Dessa forma, não partilhamos de uma apreensão linear e romântica frente à inclusão (entendida como oposta à exclusão) de quaisquer grupos sociais na escola pública. Os termos inclusão/exclusão hoje são usados com o fim de obstaculizar o entendimento de uma oposição estrutural que é a do capital x trabalho, na medida em que ambos passaram a ser usados também por organismos internacionais. Não tratamos de exclusão, termo que entra até nas agendas de setores neoliberais, dado que foi "pasteurizado" em germe mais poderoso de denúncia. O termo "expropriação"34 (LEHER, 2012), que remete à oposição capital x trabalho, traduz melhor a incapacidade de os países capitalistas conviverem todos ao mesmo tempo com uma proteção social que assegure dignidade universalmente. Inclusive no campo da educação, tão alardeada como bem maior entre grupos liberais. O que, entre outros fatores, explica o Welfare State para uma margem bem pequena da população do globo terrestre. Se todos os países vivessem nos padrões da "época de ouro" dos regimes de bem-estar europeus, não estaríamos mais no capitalismo.

No entanto, acreditamos que a classe trabalhadora não deve impor a si limites à luta por conquistas sociais, baseada nas limitações que o capitalismo impõe a ela para sobreviver como modo de produção. As lutas por políticas sociais devem ocorrer no capitalismo e contra ele simultaneamente, por mais difícil e contraditório que isso possa parecer. Foi com esse pensamento que buscamos ir a campo e realizar nossa pesquisa,

\footnotetext{
${ }^{34}$ Roberto Leher (2012) explica que o termo "inclusão" vem sendo subtraído daquilo que o colocava em uma agenda progressista nos últimos anos, o que tem efeito mais grave quando é contraposto à exclusão. "É como se no lugar da dicotomia entre exploradores e explorados, burgueses e trabalhadores, tivesse surgido uma nova oposição fundamental: incluídos versus excluídos. No contexto do capitalismo atual, os proprietários dos meios de produção, os altos assalariados, os trabalhadores que ocupam cargos nos sindicatos associados ao capital portador de juros dos fundos de pensão e a classe-que-vive-do-própriotrabalho e é explorada (com ou sem contratos formais) estariam todos irmanados, igualmente, no rol dos socialmente incluídos. Os excluídos, por alguma fortuna, seriam aqueles atingidos pela pauperização e o desalento, efeito disfuncional da economia a ser ainda mais liberalizada e do sistema educacional que supostamente não estaria garantindo que eles adquirissem as competências demandadas pelo mercado". (LEHER, 2012, p. 235).
} 
acreditando que avanços são possíveis. A seguir, apresentaremos os dados coletados e as análises que realizamos para compreendermos mais amiúde a escolarização de crianças acolhidas. 


\section{CAPÍTULO 3}

\section{AS ESCOLAS, AS UNIDADES DE ACOLHIMENTO E PERMANÊNCIA ESCOLAR}

A criança, ao término de uma idade dada, se converte em um ser totalmente distinto do que era no começo da mesma.

(VYGOTSKY, L. S., 1996a, p. 265)

No presente capítulo, buscaremos discorrer sobre a realidade encontrada nas escolas e nas unidades de acolhimento pesquisadas em conformidade com o primeiro objetivo específico de nossa pesquisa. Procederemos primeiramente às análises junto às profissionais das escolas e unidades de acolhimento, mulheres em imensa maioria ${ }^{35}$, a fim de que posteriormente façamos as vinculações entre ambas. Trata-se, dessa maneira, de entrevistas realizadas com professoras, gestoras de escola e coordenadoras de unidades de acolhimento por meio de formulários com perguntas abertas e fechadas. Importa ressaltar que, quando analisamos os dados produzidos nas entrevistas com gestoras e professoras, pautamo-nos tanto por suas falas, em busca de um teor qualitativo, quanto pelas respostas que assinalaram caráter objetivo. Ainda que menos frequentes, algumas poucas respostas que concorriam em importância com a fala mais incidente também receberam tratamento analítico.

Com a finalidade de situarmos melhor as escolas em termos de aprendizagem e até socioeconomicamente, consideramos importante o conhecimento dos valores do Índice de Desenvolvimento da Educação Básica (Ideb) de cada uma à época da coleta de dados, o qual se refere à aferição ${ }^{36}$ no ano de 2011: Escola Bege (B) - 5,4; Escola Carmim (C) - 5,8; Escola Dourado (D) - 5,4; Escola Grená $(\mathrm{G})$ - 4,9; e Escola Ferrugem (F) - 5,7. O Ideb é calculado pelo Instituto Nacional de Estudos e Pesquisas Educacionais Anísio Teixeira (Inep), que é uma autarquia federal vinculada ao Ministério da Educação. Seus valores variam de 0 a 10 e

\footnotetext{
${ }^{35}$ A maioria dos profissionais de educação e da assistência social entrevistados eram mulheres. Por essa razão, usamos pronomes e artigos femininos para nos referirmos a elas.

${ }^{36}$ As escolas foram codificadas por nós em diferentes cores, as quais não indicam nem apreço nem desapreço pelo trabalho que desempenham.
} 
servem para apontar a aprovação e a média de desempenho dos estudantes em língua portuguesa e matemática. Dois dados servem para efetuar o seu cálculo: os que dizem respeito à aprovação escolar, obtidos por meio do acesso ao Censo Escolar/MEC; e as médias de desempenho nas avaliações do Inep: o Sistema de Avaliação da Educação Básica (Saeb) e a Prova Brasil. Conhecer o Ideb significa muito mais que entender o desempenho dos estudantes. O estudo realizado por Duarte (2013) apontou que a população pobre se relaciona com a escola pelas vias do fracasso escolar, sendo que o Ideb tem o poder de evidenciar o chamado "insucesso". A citada autora tem como achado de pesquisa que:

O impacto da população em situação de pobreza no Ideb é inconteste, entretanto, não é o mesmo em todas as escolas, pois há elementos da organização do trabalho pedagógico que modulam esse impacto, e depende também do município, do estado e da região. (DUARTE, 2013, p. 355).

O índice por escola fornece-nos um dado importante sobre o estabelecimento de ensino e seus usuários, embora não possamos esperar regularidades fixas do fenômeno "Ideb baixo = pobreza", dado que ele é resultado de um contexto social, como Duarte (2013) nos adverte. Conforme o site do Inep, “as metas estabelecidas pelo Ideb são diferenciadas para cada escola e rede de ensino, com o objetivo único de alcançar seis pontos até 2022, média correspondente ao sistema educacional dos países desenvolvidos", dentro do concebido pelo Plano de Desenvolvimento da Educação (PDE), de 2005.

A média do Ideb em 2011 em todo o Distrito Federal foi de 5,4. Assim, as escolas aqui elencadas não apresentavam uma distância significativa daquilo esperado para todo o Brasil em 2022, o que se sinaliza como um dado favorável a elas no tocante aos aspectos socioeconômicos dos grupos que as frequentam. Não nos caberá aqui uma crítica densa ao Ideb, no entanto partilhamos da compreensão de diferentes autores (AFONSO, 2005; SOUZA, 2003; CHIRINEA, 2010) de que este índice, como instrumento de regulação do Estado, resulta em propostas de políticas para a educação no país, tendo em vista que determina e institui metas para os diferentes sistemas de ensino, aspiração que busca mobilizar gestores para perseguirem tais metas, conforme o estipulado.

Na medida em que as escolas e sistemas de ensino venham a ser responsabilizados pelos resultados que alcancem, acabam por se inserir em um quadro bastante competitivo dentro de uma lógica de mercado, ou seja, sob uma perspectiva neoliberal; embora o mesmo Ideb possa prestar, por outro lado, informações importantes como a relação entre pobreza e insucesso na escola. 
Do ponto de vista físico, as escolas visitadas na pesquisa de campo eram todas bastante cuidadas e limpas. As salas de aula apresentavam-se ambientadas adequadamente conforme o ano de escolaridade dos alunos e as fachadas dos prédios bem pintadas e conservadas, livres de pichações. Todas sofreram pequenos reparos e/ou reformas no decorrer das visitas. O fato de nenhuma ter sido visitada menos que quatro vezes fez com que constatássemos uma regularidade na manutenção das escolas. Mantidas com recursos do Programa Dinheiro Direto na Escola (PDDE) enviados pelo Governo Federal e pelo Programa de Descentralização Administrativa e Financeira (PDAF), proveniente do Governo do Distrito Federal, as unidades de ensino pareciam se manter longe da depreciação de parte dos prédios e residências situados em suas redondezas. O fato de essa aparência física ser obra do gerencialismo $^{37}$ é passível de discussão, uma vez que os recursos enviados pelos governos federal e local não cobrem uma manutenção contínua de fachadas, cercas e muros, fator que muitas vezes obriga a escola a fazer festas para arrecadar dinheiro para esse tipo de despesa.

\subsection{As entrevistas com docentes}

Em resposta às perguntas iniciais da entrevista quanto ao conhecimento do ECA (questões 1 e 2 do formulário Anexo A), de modo geral, as docentes diziam conhecer os arts. 53, 56, 98 e 101. Assim, do ponto de vista meramente formal, dentre as docentes entrevistadas nas cinco escolas (B, C, D, F e G), não havia estranhamento quanto a esse instrumento legal. Os arts. 53 e 56, que abordam o direito à Educação, eram conhecidos por todas, e apenas duas desconheciam os arts. 98 e 101, relativos às medidas de proteção. Sobre como tomaram conhecimento do ECA (questão 3), as professoras apontaram diferentes meios, conforme respostas a uma pergunta que aceitava múltiplas escolhas. Houve um total de sete ocorrências que afirmavam terem adquirido conhecimento sobre o ECA em momentos

\footnotetext{
${ }^{37}$ Para Shiroma e Campos (2006), o gerencialismo dentro do setor Educação vem a ser "um movimento que tenta modificar não só a organização da escola, imprimir outra lógica ao funcionamento do sistema educacional [...], mas também visa, sobretudo, a operar uma transformação na subjetividade dos educadores por meio da implantação de mecanismos bastante objetivos de controle que afetam a organização, avaliação e, portanto, a gestão do trabalho docente" (SHIROMA; CAMPOS, 2006, p. 226), concepção administrativa de viés neoliberal que impele a direção da escola a dar respostas criativas a todas as demandas, mesmo que com precariedade de recursos materiais ou financeiros. Não raro utilizam-se de festividades e bazares como fontes extras para o pagamento de despesas e dívidas da escola.
} 
realizados na escola; oito em cursos fora da escola ${ }^{38}$; e outras sete disseram ter entrado em contato com o ECA durante a graduação, conforme aponta o Gráfico 1.

\section{Gráfico 1}

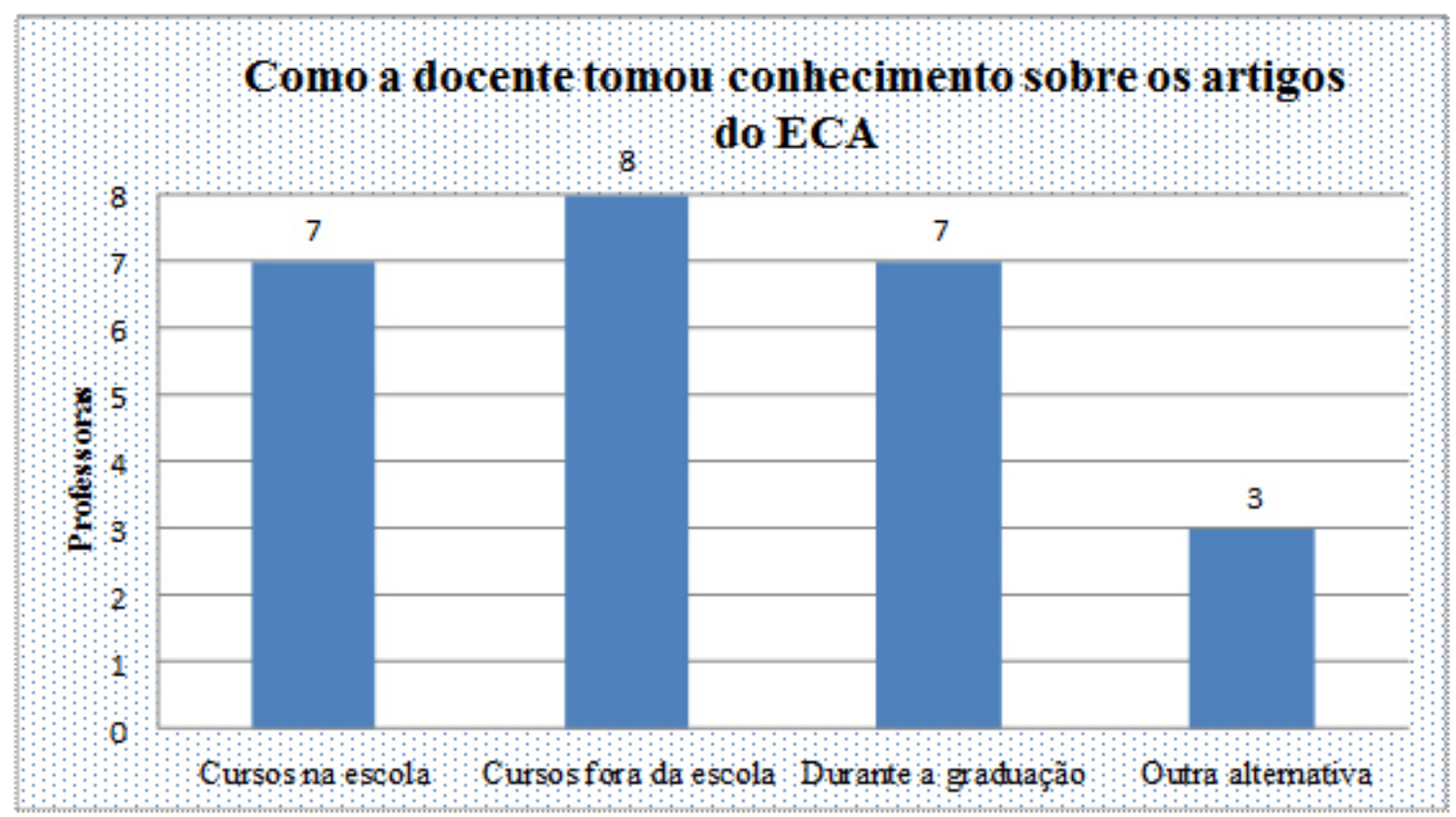

Total de 15 professoras/múltiplas respostas.

Fonte: Elaboração própria com base em dados de pesquisa. Distrito Federal, 2013.

Embora o dado pareça satisfatório, uma vez que não desconheciam o ECA, em nossa análise pareceu haver certa ausência de conhecimento histórico dos fatos que levaram à sua criação, principalmente pelo julgamento radical que muitas proferiram sobre a conduta de famílias populares com seus filhos. Obviamente, as interpretações sobre o estatuto variam conforme as instituições que mediaram o debate sobre ele. Daí tantas diferenças de percepção quanto ao valor e à aplicabilidade do estatuto.

A necessidade de conhecer as principais dificuldades e problemas que frequentemente afetavam os alunos acolhidos ou não gerou uma das respostas mais problematizáveis no tocante às bases materiais objetivas em que o alunado vive e tem sua educação mais preliminar. Em um total de 15 respostas a uma pergunta que não comportou alternativas a serem assinaladas (questão aberta), quanto aos principais problemas e dificuldades encontrados junto aos alunos (questão 4), quatorze docentes responderam que a família (ou a ausência dela) era um grande óbice para o melhor desenvolvimento da vida escolar dos alunos

\footnotetext{
${ }^{38}$ O projeto "Escola que Protege" (MEC) não é oferecido ao Distrito Federal desde o ano de 2012, nenhuma professora mostrou conhecimento do projeto, nem da presença de seu material na escola, o qual é bastante elucidativo ao abordar a longa luta pelos direitos das crianças e adolescentes e as conquistas que ainda se fazem necessárias. Em consulta ao MEC tivemos a informação de que remessas do material teriam sido enviadas para municípios com maiores índices de violência no ano de 2014.
} 
em razão da conduta que estabelecia para com eles. Tal entendimento incluiu as crianças em acolhimento pelo papel educativo não desempenhado a contento (como coadjuvante da escolarização) pela unidade em que estavam residindo.

Importa apontar algumas falas proferidas pelas professoras, para que a escolha analítica que fizemos tenha mais sentido. Alguns trechos:

Às vezes eu me pergunto: cadê os pais dessas crianças, que não estão acompanhando? Eu olhei um caderno todo de um aluno que eu estava acompanhando e perguntei: - E sua mãe, viu isso? Claro que não. Porque uma mãe, em sã consciência, em cuidados diretos com o filho, no primeiro bilhete, na primeira desorganização, vai procurar a escola. Outro fator, assim, é a falta de acompanhamento, não é? [...].

Os alunos não têm acompanhamento familiar. Não têm. Então a gente verifica, assim, que tem uma diferença enorme do que tem acompanhamento familiar para o que não tem. De rendimento, de tudo! [...].

O único mesmo é a família. E no caso do lar (da unidade de acolhimento), a gente vê ser mais gritante, claro, eles têm um local para morar. Eles não vão ficar na rua, mas ao mesmo tempo eles não têm uma pessoa que se dedica só a eles $[\ldots]$.

Eu diria que esse consumismo, essa coisa de ter, ter, ter e não valorizar... Você pode ver a sujeira da escola. O tanto que eles não valorizam caderno, livro, não valorizam nada. É algo que a gente sofre muito em sala... Vi entrega de livros do Programa Nacional do Livro Didático e na primeira semana ele está todo depenado... já está todo sujo, todo estragado. Você fala pra ele, orienta que aquilo vai ter que durar vários anos... Orienta a família, eles não têm essa noção. Não têm mais esse compromisso de cuidar. Não têm mais aquele cuidado, aquele zelo, aquele compromisso! E falo em compromisso familiar, que é algo que acaba acarretando na criança. Se pai e mãe são relaxados... Eu falo compromisso no geral, com o dever de casa, com a atividade que tem que ser desenvolvida, com o uniforme que tem que vir limpo... Uma cabeça que tem que estar catada de piolho. Sabe compromisso? [...]

(Entrevistas à pesquisadora)

O acompanhamento familiar é citado reincidentemente como um elemento em falta, uma perda irreparável para a criança, já que a escola parece impotente diante dessa constatação. A expectativa de que a família cumpra um forte papel na escolarização dos filhos aparece como inabalável e inquestionável. Não houve, por parte das docentes, uma ponderação frente a uma impossibilidade dos pais de levarem a termo as tarefas que consideravam relevantes. O conteúdo exposto nas entrevistas é de uma defecção de competências contumaz dentro da conduta familiar. Em diferentes aspectos, nos discursos das docentes, as faltas se mostram instaladas: não há capital cultural (BOURDIEU, 1999) a ser transmitido às crianças; a maternagem é vista como inadequada, uma vez que difere do 
modelo desvelado pequeno-burguês; não há presença vigilante dos pais na escolarização das crianças.

A dessintonia com a realidade dessas famílias chega a um ponto em que não há questionamento pelas docentes sobre o grau de escolarização de seus componentes, nem sobre sua efetiva disponibilidade de tempo e espaço para exercer o citado acompanhamento escolar. Não nos propomos a negar que o zelo familiar pesa na escolarização. Lahire (1997) situa a disponibilidade parental como tão importante quanto o capital escolar que porventura venha a existir. No entanto, é função da escola repensar-se nas atividades em classe e naquelas domiciliares, avaliando os objetivos das tarefas: se são meros exercícios de disciplinamento do corpo infantil, se são elementos para promover a coesão familiar ou se são uma prática de fixação dos conteúdos ministrados, entre outras possibilidades, a fim de perceber se as tarefas são exitosas para as crianças. Particularmente, naquilo que diz respeito aos deveres de casa monitorados pela família, Carvalho (2004) argumenta que:

Se, por um lado, o dever de casa poderia ser visto como um incentivo à construção do habitus requerido pelo sucesso escolar e pela empregabilidade, por outro lado, como afirmam Kralovec e Buell (2000), é uma maneira de remodelar vidas para se adequarem aos requisitos do capitalismo corporativista. (CARVALHO, 2004, p. 103).

Observação que merece ser levada em consideração por toda a escola, particularmente quando o Estado se isenta de suas funções primordiais e descobre a família como o grande pilar de sustentação e proteção dos indivíduos, adultos ou crianças. A mesma autora afirma ainda que:

Há que se levar em conta, ainda, a perspectiva da família, segundo a qual o dever de casa pode ser visto como uma necessidade legítima e uma prática desejável, ou como um fardo e uma imposição, dependendo de condições materiais e simbólicas variáveis. (Idem, p. 95).

O momento de reexame das práticas escolares passa também pelo entendimento não só da diversidade fenotípica das crianças, mas sobretudo pela compreensão acerca da diversidade das famílias que são responsáveis pela socialização primária delas. Urge, em nome de uma educação democrática, avaliar as possibilidades das famílias em cumprir exigências que em alguma (ou em grande) medida fogem à sua própria realidade cultural, afetiva e econômica, exigências que muitas vezes são incompatíveis com as realidades em que vivem os familiares e cuidadores das crianças, mas perfeitamente compatíveis com um quadro neoliberal de política educacional, intimamente ligado aos ditames da produção capitalista. 
É importante, por outro lado, que se reitere o quanto a escola e fundamentalmente as professoras dos anos iniciais de escolarização são pressionadas por resultados, em uma situação de quase solidão monitorada. Daí a ênfase no acompanhamento familiar nas questões relativas à escola, como elucida Oliveira:

Os professores são, em geral, considerados os principais responsáveis pelo desempenho dos alunos, da escola e do sistema no contexto de reformas educacionais. Diante das variadas funções que a escola pública assume na atualidade, os professores encontram-se muitas vezes diante da necessidade de responder a novas exigências. (OLIVEIRA, 2008, p. 29).

Percebe-se, dessa maneira, que a docência foi assoberbada de tarefas e de atribuições (inclusive de ordem legal) que extrapolam a sala de aula, tais como a participação na gestão escolar e nas escolhas diretas para diretores e coordenadores escolares. Não se trata de fazer crítica à democracia na escola, mas de verificar como ela está sendo posta em sacrifício ao ser feita às custas de sobrecarregar quem atua diretamente com o aluno. Cabe acrescentar que as professoras devem se apresentar como candidatas aos conselhos escolares e eventualmente às representações por escola em atividades como reuniões e capacitações fora do âmbito escolar, a fim de que retornem como multiplicadoras do conhecimento acumulado. Ou seja, assoberbadas de tarefas, as professoras e as escolas tendem a se voltar para os familiares com vistas a partilhar as responsabilidades quanto à escolarização dos alunos, uma vez que sentem a limitação que têm no âmbito de um Estado cada vez mais retraído em seus papéis sociais.

Como sublinha Oliveira (2008), a gestão democrática não é tarefa restrita, pressupõe o trabalho coletivo de elaboração do planejamento escolar e dos programas e currículos; entretanto, depositando-se tantas atribuições à rotina das professoras, ela pode se tornar um fardo. Não se pode ter uma escola democrática quando a docência em 200 dias letivos é realizada em regime intensificado, agregando novas atribuições e sob diferentes níveis de precarização (GARCIA; ANADON, 2009), medidas que se tornaram possíveis graças às mudanças verificadas no mundo do trabalho nos últimos decênios, em que, de meros insumos nas décadas de 1950 e 1960, docentes passaram a ser "considerados os principais responsáveis pelo desempenho dos alunos, da escola e do sistema, tendo sobre suas costas a responsabilidade pelo êxito ou fracasso dos programas". (OLIVEIRA, 2008, p. 33).

Uma diversificação tão grande de atividades cotidianas leva a indagar em que momento as professoras podem se deter mais amiúde à narrativa sócio-histórica dos alunos e inclusive questionar com fundamentos os repertórios ideológicos em que se baseiam para fazer suas análises diante das particularidades familiares de tais crianças. $\mathrm{O}$ discurso que aborda a 
“desestrutura das famílias" que se encontram fora do padrão burguês recorrentemente é proferido na escola. Ele não passa de um pensamento caudatário da sociologia estruturalfuncionalista, que não condiz com ideais de superação da ordem capitalista.

A análise feita por Mioto (2004), dirigida ao trabalho de profissionais do Serviço Social, merece ser examinada por aqueles que trabalham com educação. Se estes últimos já compreendem que a composição das famílias varia, falta-lhes refletir que não se pode esperar "um mesmo padrão de funcionalidade das famílias, independentemente do lugar em que estão localizadas na linha da estratificação social, padrão este calcado em postulações culturais tradicionais referentes aos papéis paterno e materno, principalmente”. (MIOTO, 2004, p. 4). Então é importante ponderar que, ao se questionar o papel das mães que deslizam do normativo, muito facilmente se incorre em injustiças brutais por falta de percepção do lugar teórico (paradigma estrutural-funcionalista) em que essas cobranças se verificam.

Em segundo lugar aparecem três outros problemas como mais citados pelas professoras quanto aos alunos em geral: a dificuldade de aprendizagem, a falta de atenção e a falta de comportamento adequado por parte dos alunos. Todos bastante recorrentes na literatura acadêmica de diferentes matizes ideológicos, tendo em vista que podem contribuir para o fracasso escolar e colaborar para o tensionamento da relação professor-aluno. Embora menos incidentes e assim menos considerados pela análise de conteúdo, acreditamos importante abordá-los por se tratar de aspectos que ampliam a percepção do ambiente escolar com o qual nos envolvemos durante a pesquisa.

No que diz respeito aos três problemas, consideramos que a escola não está livre das contradições e conflitos próprios de uma sociedade de classes. As citadas dificuldades e intempéries sofridas por aprendizes não são ocasionadas por problemas individuais deles, cabendo à instituição de ensino discutir interdisciplinarmente os problemas que acontecem dentro dela, proporcionando aprendizagens aos alunos, em que pesem as contradições desse processo. A escola cumpre o dever de ensinar e propiciar condições para que os alunos aprendam. Sendo assim, necessita munir-se com recursos didáticos e teóricos para receber crianças e adolescentes em sua diversidade regional, etnorracial, cultural e de classes sociais, tornando viável o acesso ao conhecimento entre alunos de variadas procedências. Afinal, ensinar não é tarefa mecânica e fácil, tratando-se ainda de um procedimento que visa a construir comportamentos que negam a capacidade de expansão do corpo para que o aprendizado aconteça, o que pode parecer cruel e desmotivador para alguns grupos de crianças caso não sejam convencidos dos frutos a serem colhidos com a construção dos 
hábitos do estudo. Gramsci não negou isso, ao mesmo tempo em que se convenceu da necessidade da disciplina:

Deve-se convencer muita gente de que o estudo é também um trabalho, e muito cansativo, com um tirocínio particular próprio, não só intelectual, mas também muscular-nervoso: é um processo de adaptação, é um hábito adquirido com esforço, aborrecimento e até mesmo sofrimento. (GRAMSCI, 2004, p. 51).

Por outro lado, Tacca e Branco (2008) denunciam que a escola, ao tentar ser democrática, agindo de maneira igual para com todos os alunos, desconsidera diversidades e comete inadequações severas ao não acessar as pessoas em sua concreticidade, em suas distintas formas de ser e de pensar. Ambas afirmam que urge um processo permanente de reflexão sobre as relações de ensino-aprendizagem no espaço interativo das salas de aula, onde alunos e professores estão a se envolver em suas tarefas. A partir de suas pesquisas, com aporte em Vygotsky, Tacca e Branco (2008) concluem que:

As estratégias de um bom professor, por diferentes que sejam, devem sempre incentivar as crianças para a aprendizagem que sempre acontece na conjuntura de diferentes processos de significação. O saber, visto enquanto processo, é gerado nos entrelaçamentos dos saberes que provêm das crianças, o que possibilita a promoção do pensamento reflexivo na relação com a realidade a ser aprendida, apreendida. (TACCA; BRANCO, 2008, p. 46).

Podemos dizer que conhecer concretamente os alunos não é somente um princípio humanista, é um passo para a conquista da aprendizagem. No que diz respeito aos comportamentos considerados inadequados, sejam violentos ou não, abraça-se uma leitura que não individualiza o problema da indisciplina escolar. De outro modo, ressignifica-a em um ambiente que não foi concebido para as múltiplas formas de ser e de existir, embora o entendimento de que a escola deva ser um espaço acolhedor da diversidade humana esteja presente em extensa publicação acadêmica hoje disponível, inclusive em publicações oficiais, como aqueles destinados aos profissionais do magistério, distribuídos pela Secretaria de Educação Continuada, Alfabetização, Diversidade e Inclusão (Secadi) ${ }^{39}$.

No entanto, quando se trata de comportamento em sala de aula, espera-se uma padronização por parte de pessoas com vivências muito distintas frente às diversas

\footnotetext{
${ }^{39}$ Mesmo frente ao crescente conservadorismo presente no Congresso Nacional, a Secadi conseguiu viabilizar a publicação de cadernos que se atêm a temas sobre diversidade tão distintos como as questões etnorraciais, de gênero e diversidade sexual, geracionais, regionais e culturais, além de formular a respeito dos direitos humanos e da educação ambiental. $O$ material está disponível em: $<$ http://portal.mec.gov.br/index.php?option=com_content\&view=article \&id=14772\%3Aeducacao-em-direitoshumanos\&catid=194\%3Asecad-educacao-continuada \&Itemid=913>.
} 
instituições. É como se as regras na escola fossem naturais, a-históricas e portanto imutáveis, impassíveis de negociação. O sujeito que as transgride é que se torna individualmente um problemático, embora qualquer evento ocorrido em espaço escolar jamais possa ser tomado como uma questão pessoal. A questão da autonomia do aluno frente ao que está estabelecido não é habitualmente levada em conta a fim de permitir a revisão das práticas em curso no âmbito escolar, o que contradiz a percepção de que ele seja um sujeito de direitos. É preciso investigar se as insurgências não ocorrem como uma abertura de canal para um diálogo mais consistente em torno de demandas específicas que, uma vez atendidas, podem tornar a aprendizagem mais facilitada e factível.

Especificamente quanto aos problemas vivenciados com alunos acolhidos (questão 5), foram citados, nos relatos obtidos junto às docentes, problemas como a carência afetiva, a baixa autoestima e a falta de referência materna, sendo que as duas primeiras citações foram as mais recorrentes. Não se pretende negar os impactos que a perda da contínua convivência familiar e comunitária possa produzir nas crianças, mas, ao contrário, indicar que o presente e o futuro dessas crianças não podem ser determinados exclusivamente por esses eventos pretéritos de carência e privação de afetos.

As contribuições contidas nos estudos de Bock e Gonçalves (2005) e de Aguiar (2012) que não endossam a existência de psiquês estáticas e universais são providenciais ao mostrar que os seres humanos são interpelados continuamente por novas vivências e histórias que os modificam e que os fazem modificar o mundo. As crianças não precisam ser vítimas inertes do passado, afinal o processo de subjetivação não termina nunca. Dessa maneira, é bastante promissor que as crianças acolhidas sejam percebidas não somente como sujeitos maltratados e privados de carinho ou atenção, mas sujeitos que carregam possibilidades, desde que atendidas em suas necessidades básicas, ou seja, aquelas que, quando satisfeitas, contemplam “o pré-requisito ou as condições prévias suficientes para o exercício da cidadania". (PEREIRA, 2000, p. 26).

Naquilo que se refere à autoestima, Franco (2009) afirma que a discussão desse sentimento passa necessariamente pela proposta de um projeto político pedagógico que permita a promoção de princípios de solidariedade e identidade de classe. Não é possível transformar a autoestima fora de sua trama social. A autora assevera que a autoestima passa pelas condições de vida das pessoas e, nesse caso específico, por uma escola de qualidade. É preciso que a escola se envolva afetivamente com cada criança, não como suplência do que lhes falta afetivamente, mas como parte importante de sua formação: uma formação que pode 
garantir a experiência de outros afetos. Afinal, na vida não se tem todos, mas há de se tê-los em alguma medida. E sem dissociá-los da dimensão racional à qual a escolarização se propõe. Afinal, a aquisição do conhecimento é exercício afetivo, a aprendizagem pressupõe afeto, como ensinar deve partir do mesmo pressuposto. Martins (2013) expõe teoricamente sua posição em cima de um aventado desacordo entre emoção e razão, não reconhecendo benefícios nessa abordagem. Aponta inclusive as perdas que tais posicionamentos representam para os indivíduos e para a escola:

Dentre tais equívocos destacamos as críticas que incidem sobre a educação escolar que valoriza a racionalidade postulando que, por isso, ela estaria desconsiderando as outras dimensões da personalidade humana. Por esse caminho, essas posições conduzem não apenas à desvalorização dos aspectos cognitivos e dos próprios conteúdos escolares, como também ao próprio empobrecimento da vida afetiva dos indivíduos. (MARTINS, 2013, p. 297).

Abordar a aprendizagem como tarefa que envolve a dimensão emocional e afetiva não quer dizer uma vivência afetuosa, conforme podem interpretar alguns. Acredita-se que é necessário redimensionar os afetos para além daquilo que se vive em família, quando ela de fato os propicia. As crianças assim podem viver emoções agradáveis na escola e fundamentalmente na aprendizagem, desde que a escola se proponha pedagogicamente a esse intento. Quanto à imensa expectativa docente de a família promover situações de afeto com as crianças e adolescentes, há de se pensar nisso em seu caráter novidadeiro. Só muito recentemente, quando da vinculação do amor romântico ao casamento, as famílias, mormente burguesas, passaram a se pautar com maior acento por laços afetuosos, sendo que a violência intrafamiliar tem uma trajetória longa nas sociedades ocidentais. Sobre isso Leal (1998) considera que:

A violência no contexto familiar não é uma questão nova, ela atravessa os
tempos e se constitui em uma relação historicamente construída a partir das
relações de poder, gênero, etnia e de classe social. Em outras palavras, a
violência intrafamiliar é uma expressão extrema de distribuição desigual de
poder entre homens e mulheres, de distribuição desigual de renda, de
discriminação, de raça e de religião. (LEAL, 1998, p. 19).

Famílias reguladas também pela afetividade possuem uma historicidade, não podendo ser vistas como algo natural. É importante, nesse sentido, pensar as condições que fazem emergir a discussão em torno do chamado "abandono afetivo", na primeira década do século XXI, a qual vem ocupando um bom espaço no debate travado dentro do Direito de Família: tema relevante, mas que ainda carece de conteúdo mais crítico que relacione a possibilidade de construir afetos consistentes e duradouros em sociabilidades capitalistas, inclusive porque 
a carência dos afetos não aparece como característica única daqueles que foram retirados do seio familiar por medida protetiva.

Nesse tocante, deve-se considerar o que a psicanálise também vem elaborando sobre afetividade nos setores médios da população, pensando sobre a repercussão das rotinas massacrantes dos casais heterossexuais no desenvolvimento dos filhos, particularmente com o ingresso das mães no mercado de trabalho e a continuidade das jornadas laborais paternas. Birman (2005) analisa que crianças e jovens são colocados à deriva em um mundo que exige mais de seus pais como trabalhadores. Ainda que estejam bem cuidados, com uma agenda carregada de atividades esportivas e culturais, o psicanalista afirma que:

Tal preenchimento de tempo não tem a mesma economia afetiva que a presença dos pais. Esses, no melhor dos casos, são substituídos por empregados, que também não têm a mesma incidência afetiva do que as figuras parentais. $\mathrm{O}$ efeito maior disso é um sentimento de abandono que é provocado, pois, repito, a relativa ausência materna não foi substituída pela maior presença paterna. (BIRMAN, 2005, p. 15).

Ou seja, a questão do afeto parece ser fonte de debate dentro das distintas áreas de pesquisa, sendo vivenciada por distintas classes sociais, embora com diferentes repercussões entre elas. Dito isso, é preciso que se relativize o que se tem em mente ao dizer que as crianças acolhidas são carentes afetivamente. São mais carentes que as de classe média baixa ou alta? Teriam sido sempre assim? Pedir carinho é sempre um sinal de carência ou é um dado de confiança de que o outro tem aquilo que se reivindica? Haveria uma medida ideal para o carinho? "Os afetos não são passíveis de regulação pelas orientações médicas, psicopedagógicas e legais. Desse modo, o que se apresenta é o velho modelo familiar vestido com novos trajes politicamente corretos". (SOUZA; CUNHA, 2011, p. 10).

Então é bastante razoável, em se tratando do público escolar, que não se espere sempre um lar afetuoso, em moldes preestabelecidos, por parte dos responsáveis pelas crianças, ainda que haja um debate jurídico sobre essa expectativa. A base afetiva em que se constituem os lares parece muito diversificada, tanto quanto as sociedades complexas. Daí o cuidado ao interpretar carências afetivas a partir de um padrão de afetividade, construído a partir das narrativas burguesas. A título de debate, Buffa (2010), citando Makarenko - importante educador durante a experiência soviética -, afirma sobre a educação familiar que:

$\mathrm{Na}$ maioria dos casos, as pessoas não sabem conciliar o carinho e a severidade, coisa absolutamente necessária na educação. Frequentemente vemos que as pessoas entendem esses problemas, porém pensam: é justo que a severidade tenha um limite, que o carinho se adapte a certas normas, 
contudo, isto será necessário quando a criança tiver seis ou sete anos; até esta idade, poderemos passar sem normas. (BUFFA, 2010, p. 90).

Em que pese a diferença entre o chão cultural e político em que Makarenko pisou e aquele sobre os quais estamos erguidos, sabemos que não se trabalha com formação de crianças somente com afeto, o que seria importante problematizar em classe para que o afeto figure como mais um elemento na construção das subjetividades e da aprendizagem infantis. Quando indagamos às professoras a respeito das características positivas de crianças em acolhimento institucional (questão 11), o que comportaria no máximo três respostas abertas, obtivemos, entre outros, os seguintes relatos:

Tem uns que falam mais... Tem outros que são mais agressivos. Eles gostam muito de falar! [...] (BX5)

Por tudo que ela passou, ela quer aprender. Porque senão ela tinha feito qualquer coisa... Ela poderia "tocar o terror", como se diz por aí... Mas é tranquila, observa as normas [...] (GY2)

Gente, ele é um menino dócil, que respeita... Ele divide muito bem... Estou falando só dele. [...] (BX8)

A minha aluna, espontânea, criativa e, por incrível que pareça, amorosa! Por tudo que ela já passou, as demonstrações dela são um pouco mais limitadas que os demais. Ela era totalmente criativa, era uma criança que, quando queria... Se tivesse alguém para pegar e dizer: - Vamos lá? - Ela ia longe [...] (BX9)

Eles são muito acolhedores [...] (BX10)

Amadurecimento, a vida impõe para eles. Como não tem ninguém por eles, eles mesmos resolvem os problemas. Não consigo enxergar mais. No geral, o que observei foi isso. Eles sabem dividir mais, a criança que está em casa já não tem muito isso! Dar valor! Eles dão valor, eles têm tão pouco! [...] (BX4)

São humildes de sentimento. Trabalham em grupo bem. Têm lá suas desavenças. São carinhosas demais. Fazem cartinha, mandam beijos. Eu adoro! [...] (BX3)

Compartilham muito! Lanche, coisas [...] (FX2).

Não notei nenhuma característica. É a primeira vez que eu vejo essa situação. [...] (BX11)

Mesmo a família abandonando, eles não aceitam que falem da mãe. [...] (BX4)

Eu sinto que a gente vai falar sobre família, eles não ficam bem. Porque, assim, eles acabam que eles têm família! $\mathrm{E}$ as pessoas acham que eles são órfãos. Aí brincam... falam alguma coisa que eles não gostam... fazem brincadeira disso, acho que a maior parte mesmo da indisciplina acaba sendo assim. [...] (FX2)

Não notei. [...] (BX11)

(Entrevistas à pesquisadora) 
É possível perceber que nas respostas das professoras que se manifestaram positivamente sobre os alunos (pois algumas nada disseram contra ou a favor) há uma forte valorização dos aspectos da ordem da afetividade e da urbanidade ou civilidade. No primeiro caso, a capacidade de serem acolhedores e amorosos mesmo que enfrentando situações bastante adversas no decorrer da vida. No segundo, o elogio quanto à observância de normas, o compartilhamento de alimentos e coisas. Ainda que o reconhecimento de tais características seja importante, não há menção a capacidades estritamente ligadas ao aproveitamento escolar das crianças, ou seja, suas respostas ao trabalho desenvolvido em classe. Embora exista um depoimento de que uma das alunas "quer aprender", não se vê uma argumentação que demonstre que a menina vá além da intenção.

Não se fala das objetivações ${ }^{40}$ (DUARTE, 2001), concretizadas quando da frequência escolar. É como se as profissionais estivessem se referindo a crianças quaisquer e não a seus próprios alunos imersos cotidianamente em situações de ensinoaprendizagem. Há uma lacuna sobre as questões relativas às capacidades intelectuais desses alunos, que em nenhuma das entrevistas foi preenchida. Nenhum termo de teor positivo foi proferido quanto a isso, o que sugere um desconhecimento ou pouca avaliação sobre como eles se relacionam com conhecimentos, uma vez que entre as professoras entrevistadas havia aquelas que tinham crianças acolhidas com excelente desempenho, o que foi declarado por elas quando do preenchimento do formulário sobre seus alunos (Anexo B).

As respostas sobre as medidas tomadas pelas docentes frente a problemas de aprendizagem (questões 6 e 7) foram diversificadas. Em razão disso, buscamos dividi-las em campos de atuação, em conformidade com a tipologia das medidas: o psicológico, o pedagógico e o que pede a intervenção de terceiros. Tratou-se de uma indagação que não incorporava questões objetivas. A pergunta buscava trabalhar possíveis problemas de comportamento que influenciassem a aprendizagem e vice-versa. A seguir, as medidas adotadas em cada campo, bem como o número de citações de cada uma:

\footnotetext{
${ }^{40}$ Duarte (2001) explica que a relação entre os indivíduos e a história social é mediatizada pela apropriação das objetivações produzidas e verificadas no decorrer da história. Tendo em vista que a atividade feita pelos humanos se objetiva em produtos, "em objetivações, sejam elas materiais ou não, temos, como consequência, que o processo de objetivação do gênero humano é cumulativo. Assim, no significado de uma objetivação está acumulada a experiência histórica de muitas gerações" (DUARTE, 2001, p. 158). São essas experiências que se espera que os alunos sejam capazes de acessar pela razão.
} 
a) No pedagógico, verificou-se: a adoção de atividades mais diversificadas (2 citações); adoção de metodologia nova (1 citação); realização de projeto interventivo (1 citação); reagrupamento (1 citação); e reforço escolar (4 citações).

b) No campo psicológico, destacam-se: há um estímulo para executar as tarefas (1 citação); faz-se um acompanhamento corpo a corpo (2 citações); trabalha-se a autoestima (1 citação); e trabalha-se a afetividade (1 citação).

c) Por último, o campo que pedia a intervenção de terceiros teve como coadjuvantes na resolução dos problemas de aprendizagem ou comportamento: a coordenadora pedagógica (1 citação) ou a pedagoga da Equipe Especializada de Apoio à Aprendizagem (EEAA), em razão de estar lotada na escola (1 citação). Este último campo, menos acolhido pelas professoras nesse momento, teve uma diferente recepção na questão 7 , então não o exploraremos aqui. Deixaremos para fazê-lo quando da análise dessa citada questão.

A resposta mais recorrente ocorreu no plano pedagógico. Elas trouxeram as Diretrizes Pedagógicas do Bloco Inicial de Alfabetização (BIA) em sua materialização em pelo menos duas respostas: o projeto interventivo e o reagrupamento. Não se trata, portanto, da adoção de medidas especiais e singulares, visto que são constitutivas de diretrizes locais para o BIA. O projeto interventivo no BIA apresenta como objetivo principal "sanar essas necessidades (de aprendizagem) assim que surjam, por meio de estratégias diferenciadas. É uma proposta de intervenção complementar, de inclusão pedagógica e de atendimento individualizado". (SEDF, 2013, p. 16).

Junto ao citado projeto aparece também o reagrupamento. Como o nome sugere, trata-se de dividir as turmas de alfabetização em subgrupos, pois para as diretrizes do Bloco Inicial de Alfabetização (BIA) faz-se necessário:

Reorganizar os tempos e espaços da escola e, ao mesmo tempo, selecionar e organizar os conteúdos que atendam às necessidades específicas de aprendizagens, enriqueçam e aprofundem conhecimentos em conformidade com os interesses dos estudantes. (BIA/DF, p. 60).

Assim, na medida em que as crianças avançam na leitura e escrita, elas mudam de subgrupo até alcançarem o último nível da alfabetização, hoje denominado de A4 Alfabetizado 4.

Todas as demais medidas: adoção de novos recursos (cordel em sala de aula), atividades mais diversas e adoção de metodologia nova também se encaixam nas diretrizes do 
BIA, exceto o reforço. A atividade de reforço foi renomeada mais recentemente nas Diretrizes de Avaliação Educacional do Distrito Federal (2014-2016) como "recuperação contínua", embora ela traduza o mesmo espírito daquele, isso porque deve ser ministrado ao longo do processo de ensino. Assim:

Para que se inicie a construção desse entendimento e a prática correspondente, recomenda-se a realização de intervenções pedagógicas contínuas com todos os estudantes, sempre que suas necessidades de aprendizagem forem evidenciadas. Desse modo, o avanço das aprendizagens ocorrerá de forma tranquila, sem lacunas, sem tropeços e sem aligeiramento, de acordo com as condições de aprendizagem de cada estudante. (DISTRITO FEDERAL, 2014, p. 39).

Adianta-se aqui que, embora fornecida por algumas docentes em horário contrário ao das aulas, a recuperação contínua não tem a frequência esperada dos alunos acolhidos. Os motivos para isso estão sempre relacionados ao transporte ou a uma companhia adulta para levá-los e buscá-los na escola. Assim, pudemos perceber que as docentes deram, em segundo lugar, ênfase aos papéis desempenhados por: autoestima, estímulo e afetividade. $\mathrm{O}$ trabalho "corpo a corpo" também veio para não deixar a criança desistir das tarefas ou desencorajar-se frente a elas. A psicologia, especialmente a educacional, vem exercendo historicamente um papel de relevo dentro da educação brasileira, ainda que enviesada, muitas vezes, por uma compreensão liberal de mundo, que acaba por culpabilizar o aluno por todas as dificuldades que vivenciam na escola. Uma das problemáticas ocorridas nessa interface disciplinar diz respeito:

À responsabilização da criança e de sua família, em nome de problemas ditos de "ordem emocional", para justificar o desempenho do aluno na escola, a redução dos processos pedagógicos aos fatores de natureza psicológica colaboraram para interpretações e práticas no mínimo equivocadas, desprezando o processo educativo como totalidade multideterminada, relegando a segundo plano, ou omitindo, fatores de natureza histórica, social, cultural, política, econômica e, sobretudo, pedagógica na determinação do processo educativo. (ANTUNES, 2008, p. 472).

A preocupação aqui é que essa totalidade de fatores seja desprezada em nome de intervenções de base psicológica limitada (alijadoras do componente histórico-social) e assistemáticas, sem que haja por parte da escola uma reelaboração coletiva frente aos problemas verificados, particularmente os que acometem a aprendizagem de crianças acolhidas, com escolarização quase nunca linear. Ao abordarmos a indisciplina e as razões que poderiam fazer que ela fosse desencadeada em uma pergunta aberta onde caberiam até 3 respostas (questão 12), recebemos respostas únicas, singulares. 
Duas modalidades de respostas foram mais incidentes: a primeira, de um total de 5 professoras, afirmava o desconhecimento sobre as razões pelas quais esses eventos se desencadeavam. A segunda resposta mais incidente, perfazendo também um total de 5 professoras que se dispuseram a responder à pergunta mais detalhadamente, aborda questões relacionadas à cultura da criança, inclusive naquilo que diz respeito à sua relação com a família de origem. Entre as cinco demais professoras, uma disse não notar as motivações para a indisciplina, outra disse ainda não ter esse tipo de problema em classe, outra disse que seria alguma "questão racial". Apenas 2 professoras remeteram-se a indisposições do aluno com a escola e com seus conteúdos.

A primeira resposta mais incidente pode ser interpretada de duas maneiras: há um alheamento quanto aos fatores que levam os alunos acolhidos a se indisporem com a norma, o que conota um acompanhamento pouco sistemático das crianças. Outra possibilidade é que realmente não existe um padrão de motivações que permita identificar motivações. $O$ alheamento, ainda que grave, tem de ser observado em suas condições de produção. Não se trata de uma questão pessoal, afinal, em escolas com muitas tarefas a executar, advindas de dentro e de fora de seus domínios, cobradas por agentes públicos internos e externos, com diferentes graus de participação das professoras em sua elaboração, ou talvez grau nenhum, é impossível ater-se a tudo e engajar-se por todos.

A elaboração marxiana sobre alienação do trabalho nos Manuscritos Econômico Filosóficos de 1844 faz uma análise minuciosa sobre o alheamento inserido no âmago da sociabilidade capitalista, que se funda sobre a propriedade privada. Afinal, o processo de alienação vivido pelo gênero humano tem sua origem na divisão do trabalho, e essa divisão resulta em uma humanidade incompleta, distada da omnilateralidade, que pressupõe o crescimento das pessoas nas mais variadas direções, tantas quanto possibilitarem uma formação rica e multidisciplinar.

Marx (2003) dispôs a alienação do trabalhador (homem genérico) em quatro planos: a) a alienação da natureza - advinda de uma desumanização, que ocorre em razão de não conseguir mais fazer objetivações e apropriações ${ }^{41}$ a contento, tendo em vista estar inserido

\footnotetext{
${ }^{41}$ Duarte (2013) situa que "o produto do trabalho é sempre atividade humana objetivada" (DUARTE, 2013, p. 73), ou seja, há uma transferência de atividade humana para as características daquilo que é produzido. No entanto, dada a realidade capitalista em que vivemos, o capital se apropria dos resultados do trabalho ao mesmo tempo em que o produto se aliena, torna-se estranho, à classe que o produziu. Assim, a "forma capitalista de apropriação dos resultados do trabalho faz com que tanto a apropriação quanto a objetivação, em vez de humanizarem o trabalhador, o alienem da riqueza material e imaterial" (Idem). A contribuição de Seabra (2008) foi importante para o entendimento e sistematização mais integrados da alienação em suas manifestações.
} 
em um quadro de dominação; b) a alienação de si mesmo - quando passa a vender sua força de trabalho a um patrão, algo que não existia na produção feudal; c) alienação do gênero humano - o que quer dizer que se afasta de sua condição humana; e d) alienação do homem onde a existência diz respeito simplesmente aos fins do capital. Assim, um homem não enxerga no outro (ou na outra) a possibilidade de libertação, mas somente limitações.

Assim, não se trata de evento isolado constatar que trabalhadores de quaisquer profissões ou ocupações desconhecem tramas e eventos que se passam rotineiramente em seus locais de trabalho. Desconhecem, conjuntamente, os pilares onde a sociedade se organiza, fator que pode estar relacionado com uma graduação escassa em conteúdos que contribuam para pensar o cenário de desigualdades em que os estudantes da escola pública se inserem. Nesse tocante, Assis e Yannoulas (2012) afirmam que constataram lacunas na formação de profissionais da educação naquilo que diz respeito à abordagem sobre o tema "pobreza". Constataram:

A existência de um tratamento indireto de assuntos correlatos com a situação de pobreza, sem proporcionar ferramentas teóricas e práticas para lidar com as situações de pobreza no ambiente escolar ou perante dificuldades específicas que os estudantes pobres possam apresentar. (ASSIS; YANNOULAS, 2012, p. 260).

Assim, por diferentes dispositivos ou situações, a alienação instala-se em toda a produção e fora dela e permite que o mais imediato seja invisibilizado e incompreendido. Inclusive em sala de aula. As professoras também estão inseridas em uma trama alienante, posto que trabalham. O trabalho no capitalismo é alienante, o que vem a repercutir, não sem razão, nas relações que a escola e seus trabalhadores estabeleçam com outras instituições, sendo a recíproca verdadeira.

Dentre as respostas coletadas no segundo grupo, observamos que a animosidade, a indisciplina ou a insatisfação de crianças acolhidas podem advir de situações em que são estranhadas ou que veem seus parentes, mormente a mãe, sendo alvos de acusações ou chacotas.

Algumas expressões que ela traz de lá... Não sei se vêm (as expressões) da rua... Ela traz algumas expressões que não são típicas de aluno pequeno [...]. (GY2)

Há certa discriminação por ela estar em abrigo... é diferente a criança do abrigo... se você fala do Dia das Mães, ela já fica ofendida por não ter mãe... A falta de conhecimento (do que é abrigo) gera indisciplina [...]. (BX9)

Mesmo a família abandonando, eles não aceitam que falem da mãe [...]. (BX4) 
Não aceitam ordem, tanta gente manda neles! Estão sem norte com autoridade [...]. (BX3)

Eu sinto que a gente vai falar sobre família, eles não ficam bem... porque, assim, acaba que eles têm família! E as pessoas acham que eles são órfãos... aí brincam... falam alguma coisa que eles não gostam... fazem brincadeira disso, acho que a maior parte mesmo da indisciplina acaba sendo assim [...]. (FX2)

(Entrevistas à pesquisadora)

Surpreendentemente ou não, a família aparece como tema gerador de indisciplina quando é aventada de maneira negativa no cotidiano escolar de alunos em acolhimento institucional. O resguardo com essa instituição, principalmente com a figura das mães, mesmo pelas crianças afastadas delas por situações-limite, expõe a escola a questões importantes para que ela problematize: a família cumpre papéis importantes para esses alunos, mesmo que agindo de forma dissonante do que preconizaria o pensamento funcionalista.

Seja um lugar na memória, que aponta a tentativa de proteção, seja de afeto ou mesmo como lugar de alternâncias entre cuidado e conflito. Muitas dessas famílias ainda visitam as crianças e mesmo os adolescentes nas unidades de acolhimento. $\mathrm{O}$ direito à convivência familiar e comunitária assegura isso. Não se trata somente da defesa de entes que já se situam em um passado (por morte ou quando há a destituição do poder familiar), mas sobretudo de entes que estão presentes em suas fantasias e ilusões (palavras das professoras), mesmo que não tão frequentes em suas visitas ao local de acolhimento.

Assim, a família tem de ser vista no espaço escolar como instituição contraditória. Ao mesmo tempo em que é espaço de conservação, é também espaço de proteção e de afetos, demandas que em sociedades complexas e atravessadas por políticas neoliberais ficam cada vez mais circunscritas a esse núcleo, seja ele portador da capacidade de provêlas ou não. A família não é uma instituição frágil, vem sobrevivendo ao longo das sociedades de classes sob diferentes arranjos, ainda que sobre ela recaiam críticas de toda ordem, examinadas em diferentes campos do conhecimento, como a Psicanálise, a Sociologia, a Antropologia, entre outros.

Sobre o Projeto Político Pedagógico (PPP) da escola (questão 15), a unanimidade das professoras disse considerar importante a viabilização de medidas entre escola e 
unidades de acolhimento na formulação desse documento ${ }^{42}$. O resultado aponta para o entendimento de que as ações pela melhor permanência dos alunos acolhidos nas unidades de ensino devam ser conjuntas. Creditamos como importante que o PPP e a gestão democrática da escola sejam vistos em suas contradições, posto que passam a ser requisitos para o funcionamento da escola somente após 1996, num quadro da educação em que a LDB pavimenta o caminho para o gerencialismo na administração escolar. Entretanto, ambos devem ser aspirados como um direito da comunidade escolar (pais, mães, responsáveis, seus profissionais e alunos) na medida em que deverá dizer qual a melhor escola para si. Conforme Fonseca et alii (2010):

A escola, como esfera pública democrática, pode possibilitar a capacitação de pais, alunos e educadores na busca de soluções para os problemas da própria escola, do bairro, da cidade, do Estado, do país e da vida em sociedade. É a escola um lugar de formação, de aprendizagem e de interação da comunidade e dos vários segmentos nela estabelecidos. (FONSECA, 2010, p. 70).

As unidades de acolhimento, responsáveis por tantas crianças e adolescentes inseridos em diferentes unidades de ensino, ao exercerem o papel de coconstrutoras do PPP num quadro de efetivação da gestão democrática, podem ampliar as possibilidades de uma permanência escolar com aprendizagem para as crianças em acolhimento.

Outra questão de teor subjetivo indagava sobre a possível necessidade de haver mais profissionais não docentes dentro da escola (questão 16) para lidar com a realidade ocasionada pelos alunos acolhidos. Apenas 1 das 15 professoras entrevistadas disse que esta não seria uma necessidade da escola. A solicitação para que apontassem quais novos profissionais seriam demandas escolares recebeu como resposta majoritária o psicólogo, conforme Tabela 3. As docentes ficaram livres para apontar os profissionais que entendiam serem necessários na escola, sendo que 2 não responderam, embora admitissem que a escola precisasse de profissionais que não fossem somente aqueles oriundos de licenciaturas para a educação básica.

O peso da Psicologia na compreensão da dinâmica escolar pareceu substantivo. Tal valorização não é algo recente. Dentro da chamada Escola Nova era possível assistir a um viés psicologizante em seu corpo de ideias onde as dificuldades de aprendizagem das crianças

\footnotetext{
${ }^{42}$ Durante a coleta de dados (2013-2014), o Distrito Federal estava sob a gestão (2011-2014) do Partido dos Trabalhadores (PT) em coligação com diversos partidos. Nesse período, houve a eleição para os cargos de diretor e vice, sendo que ambos deveriam construir um PPP junto com a comunidade escolar para orientar seus mandatos.
} 
eram vistas predominantemente com os aportes da Psicologia, desconsiderando a questão em suas variadas determinações, entre elas a de cunho social. Esse tipo de mediação que a educação e os cursos de Pedagogia recebem há décadas possibilita o entendimento dos motivos que levam a Psicologia a ter uma acolhida tão dominante entre a categoria de professores.

Longe de desconhecer a importância da ciência e da profissão, busca-se aqui ponderar que há abordagens da Psicologia que permitem ver o aluno em sua totalidade: não como uma universalidade, como alguém pronto, a-histórico e passível das mesmas intervenções. Ou seja, um conhecimento psicológico que seja capaz de "assegurar a conciliação de uma cientificidade na abordagem da vida psíquica, sem o reducionismo das abordagens positivistas ou naturalistas dominantes". (SIQUEIRA, 2012, p. 85). Pensamos uma formação para a docência do ensino básico que seja mediada por conhecimentos sociológicos, antropológicos, filosóficos e inclusive psicológicos, fazendo-se interface entre todos de maneira crítica.

\section{Quadro 2 - Profissionais demandados pelas professoras}

\begin{tabular}{clll}
\hline Professora & \multicolumn{1}{c}{ Profissional/profissionais que demandaria } \\
\hline DX2 & Psicólogo & & \\
CX3 & Psicólogo & & \\
CX2 & Psicólogo & & \\
FX1 & Não respondeu & & \\
FX3 & Psicólogos/orientadores educacionais & (licenciados em Pedagogia com \\
& habilitação específica) & & \\
FX2 & Psicólogo/pedagoga & \\
BX9 & Não respondeu & \\
BX6 & Psicólogo \\
BX10 & Área de saúde (não especificou) \\
BX3 & Psicóloga \\
BX5 & Psicólogo & \\
BX4 & Assistente social \\
BX8 & Psicólogo \\
BX11 & Psicólogo, psicopedagogo e fonoaudiólogo \\
\hline
\end{tabular}

Fonte: Elaboração própria. Distrito Federal, 2013.

As únicas menções a profissionais para atuarem dentro da escola, fora da área de saúde, referiram-se a orientador educacional (cada escola atualmente já tem direito a 1 a cada 200 alunos), pedagogo (já presente nas EEAA quando atuantes e completas), psicopedagogo (especialista com formação, em geral, em Pedagogia, que eventualmente integra a equipe anteriormente mencionada) e por último assistente social. Para esta última profissão houve 
uma única menção ${ }^{43}$, o que evidencia que a problemática que envolve a educação de crianças acolhidas (com interrupções, baixa aprendizagem, evasão, etc.) não é apreendida suficientemente em suas determinações sócio-históricas, nas quais os direitos daqueles situados em maior desvantagem socioeconômica tendem a ser atendidos precariamente.

Uma profissional com formação em Serviço Social deve ter sua atuação voltada a dar respostas à questão social. Conforme publicação do Conselho Federal de Serviço Social (CFESS), inspirada em formulação da Associação Brasileira de Ensino e Pesquisa em Serviço Social (ABEPSS), cabe à assistente social a "identificação das demandas presentes na sociedade, visando a formular respostas profissionais para o enfrentamento da questão social, considerando as novas articulações entre o público e o privado". (CFESS, p. 26, 2013). As diversas expressões da questão social estão sempre a pulular na cotidianidade dessa categoria, o que vem a se repetir dentro das escolas.

Em razão disso, a pouco lembrada e talvez desconhecida atuação dos profissionais do Serviço Social na educação urge por ser considerada não como remendo aos sérios acometimentos que rasgam a rotina escolar (violência, presença de alunos vivendo violações de toda ordem, etc.), mas como profissionais detentores de um conhecimento que se presta a somar com aqueles acumulados pelas docentes. Tudo isso na expectativa de que suas atuações busquem organizar a comunidade escolar em torno da efetivação de direitos, mesmo que abordando suas insuficiências. Afinal, a inclusão escolar pálida que se oferta por meio de políticas focalizadas e carregadas de condicionalidades, a exemplo do PBF, nada tem a ver com as lutas travadas pela universalização da educação.

Se os alunos acolhidos são sujeitos atravessados por eventos que os marcam psicologicamente, também o são por eventos trágicos, perversos e carregados de injustiças, que são próprios de uma sociedade de classes, onde a riqueza de poucos convive junto à pobreza dos muitos que a tornaram possível. A "questão social” que emerge de um conflito dessa natureza pode ser apropriada com mais largueza pelas profissionais da educação em contato com outras profissionais mais diretamente ligadas à atuação nas suas diversas expressões. Acreditamos, conforme Yannoulas (2013), que:

Um dos desafios para as assistentes sociais é refletir sobre a relação contraditória entre a política educacional e a política de Assistência Social no contexto mais amplo da proteção social. Com a universalização da

\footnotetext{
${ }^{43}$ No período da realização da pesquisa nas escolas, estava em tramitação no Congresso o PL 3688/2000. O referido projeto traduzia a luta de assistentes sociais e psicólogas por suas inserções dentro da escola numa tentativa de que esta pudesse ampliar suas possibilidades de êxito junto ao alunado.
} 
educação a parcela mais pobre da sociedade entrou massivamente na escola e novos conflitos e contradições surgiram. Essa situação é particularmente significativa, pois desvenda de maneira contundente como o sistema educacional é atravessado pelo modo de produção capitalista, entremeando condições socioeconômicas com desempenho escolar e condicionalidades educacionais. (YANNOULAS, 2013, p. 17).

O somatório de profissionais docentes e não docentes na escola parece esvanecer seu papel social. No entanto, a investida é em sentido contrário, buscando potencializar o papel originário da escola, politizando o debate sobre a sua precarização como um atentado aos direitos, a despeito de quaisquer contradições. No decorrer da coleta de dados no Distrito Federal, durante a gestão de coalisão do PT, a categoria foi instada, a partir da proposição governamental do "currículo em movimento", a pensar a partir da Teoria Crítica, questionando "o que pode parecer natural na sociedade, como: desigualdades sociais [...], neutralidade do currículo e dos conhecimentos, busca de uma racionalidade emancipatória para fugir da racionalidade instrumental, procura de um compromisso ético que liga valores universais a processos de transformação social". (DISTRITO FEDERAL, 2013, p. 21).

Por outro lado, a mesma categoria vem vivenciando toda uma agenda neoliberal, interpelada entre outras possibilidades: por avaliações institucionais, por cursos aligeirados que permitem progressão na carreira, por uma massiva doutrinação dos meios de comunicação em torno do sucesso obtido pelo "esforço pessoal" de um número mínimo de oprimidos. Todas essas atrozes possibilidades e discursos concorrem deslealmente com uma percepção crítico-social da realidade, a qual se pauta por individualizar, ou seja, retirar do social os problemas vivenciados por alunos.

Assim, não se quer criticar levianamente as docentes pela maneira como pensam, pelas reivindicações que fazem, mas ponderar que a disputa ideológica ocorre com mais intensidade fora da academia e das agências de formação. A discussão do "currículo em movimento" não tem o poder por si só de mudar mentalidades simplesmente por ter argumentos voltados para a "consciência" dos cidadãos. Isso seria aquilo que Duarte (2008) chama de "a quinta ilusão", ou seja, ratificar o pressuposto de que o apelo à consciência das pessoas abre o caminho para a superação dos graves problemas da humanidade.

O autor afirma que dentro dessa ilusão reside outra, a qual entende que os grandes problemas da humanidade são consequências de determinadas mentalidades, posição na qual se apoiam, a seu ver, algumas concepções idealistas de educação. Por essa razão 
adverte: "é preciso estar atento para não cair na armadilha idealista que consiste em acreditar que o combate às ilusões pode, por si só, transformar a realidade que produz essas ilusões”. (DUARTE, 2008, p. 15). Ratificamos que não bastam bons argumentos para modificar mentalidades. Buscamos com essa digressão pensar o quão desfavorável é o período hoje posto para interpretar o aluno para além de um viés individualizante, embora isso seja factível se isso for realizado interdisciplinarmente, sem perder a perspectiva do coletivo.

Quanto ao momento de ocorrência de uma situação-limite com alunos, acolhidos ou não (questão 9), que poderia levar a docente a pedir a ajuda de terceiros a fim de uma resolução dos problemas como conflito ou agressividade em sala, as respostas ocorreram conforme o Gráfico 2.

\section{Gráfico 2}

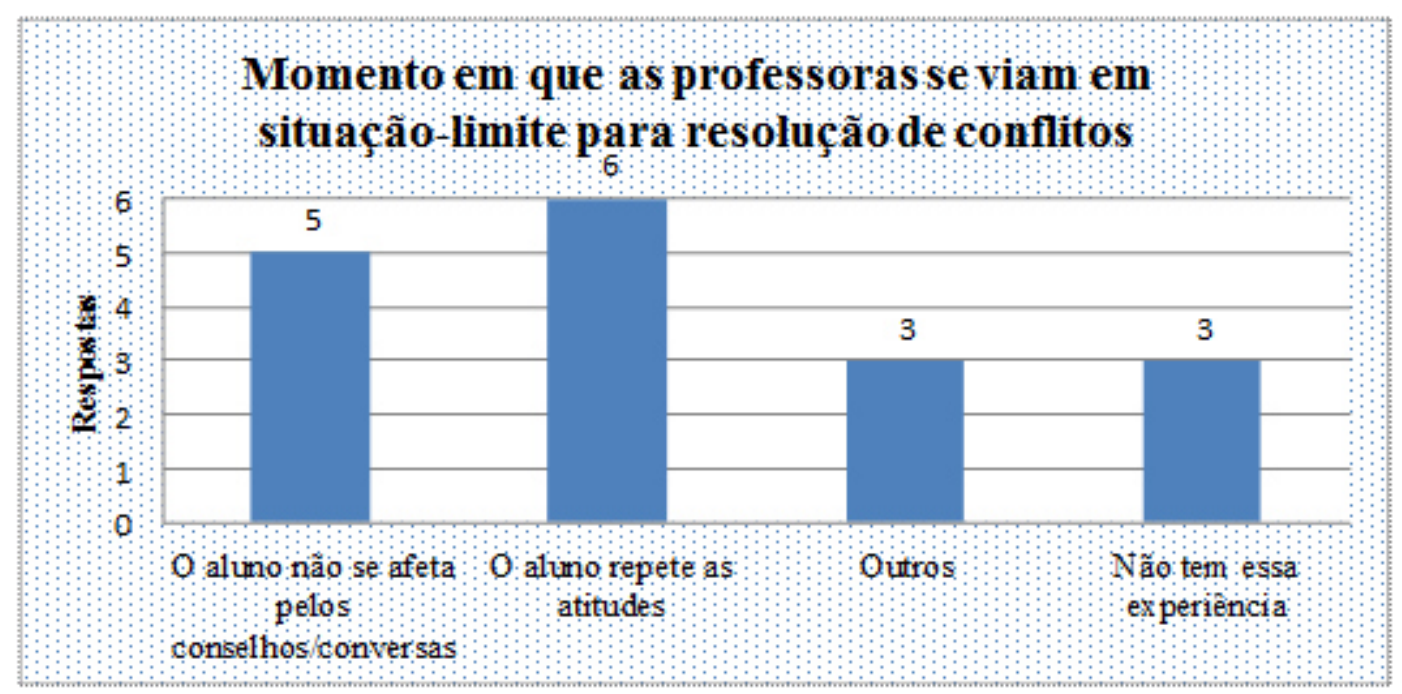

Total de 15 professoras/múltiplas respostas

Fonte: Elaboração própria com base em dados de pesquisa. Distrito Federal, 2013.

Três professoras disseram não ter essas experiências conflituosas em classe. As respostas mais representativas numericamente foram as que diziam respeito a uma aparente não afetação dos alunos por conselhos e conversas e a repetição de atitudes consideradas inadequadas. Quando a opção de situações apontava para "Outros", abria-se espaço para mencioná-las. Assim, uma professora colocou-se como no limite ao não receber resposta alguma dos responsáveis pelas crianças e as agressões verbais e a impossibilidade de dar continuidade às aulas também se configuraram como limites extremos para uma professora na mesma categoria. 
Em nossos dias, o Transtorno do Déficit de Atenção com Hiperatividade (TDAH) é frequentemente aventado como hipótese para comportamentos inadequados que não cessam sob advertências, fator que se repetiu em nossa coleta de dados. Ele é caracterizado por inquietude e impulsividade, que na concepção de Jou (2010) são interpretadas como falta de disciplina, e a desatenção como negligência, apesar de tais comportamentos serem mais relacionados a uma disfunção no desenvolvimento neurológico. "Os professores são frequentemente a primeira fonte de informação para determinar o diagnóstico do TDAH e, na maioria das vezes, são eles que solicitam uma avaliação profissional para seu aluno”. (JOU, 2010, p. 30). Ainda que não partilhemos da posição hegemônica frente ao TDAH, "entendido como decorrente de desajustes no organismo do sujeito" (LEITE, 2011, p. 111), a qual minimiza ou despreza o contexto sócio-histórico e cultural dos alunos, sabemos de sua crescente incidência na escola.

Dentre as 20 crianças acolhidas, sob as quais as entrevistas se detiveram, 9 foram encaminhadas à EEAA ${ }^{44}$. Três receberam laudos contendo acometimentos: 2 eram com TDAH e 1 portava deficiência intelectual (DI). Cabe lamentar que:

O metilfenidato, substância dada para crianças e adolescentes com a pretensão de diminuir o chamado "déficit de atenção" na escola, subiu de 70 mil caixas vendidas em 2000 para 2 milhões de caixas em 2010, inserindo o Brasil no segundo maior consumidor dessa droga no mundo, perdendo somente para os Estados Unidos. (CONSELHO FEDERAL DE PSICOLOGIA, 2013, p. 5).

Salienta-se que tanto quem preencheu a primeira quanto a segunda alternativa da questão 9 tinham o TDAH como possibilidade de resposta às próprias queixas.

O conjunto de respostas para a presente questão, ainda que distintas em seu conteúdo, não revela outro fator que os precede: a insistência em resolver as questões em classe, conforme a transcrição de depoimentos. A autonomia da professora é bastante cobrada dentro da escola, talvez por isso busquem o adiamento da ida até a direção, à orientação educacional ou a EEAA. Todas as docentes, antes de proferirem o limite para a ajuda, insistiram em dizer que buscavam resolver as questões sozinhas e em sala de aula.

As quatro alternativas colocadas para a questão do limite da docente em ocasiões conflituosas, momento em que ela pediria por ajuda em âmbito escolar, surgiram do pré-teste

\footnotetext{
${ }^{44}$ Pereira (2011a) analisa que o processo de avaliação dos alunos pela EEAA passa pela aplicação de testes, não se configurando em uma ruptura com modelos tradicionais. Em casos persistentes de dificuldade de aprendizagem, há indicação, por parte dela, de um serviço médico para o atendimento do estudante. A mesma autora critica, com coerência, a visão recorrentemente partilhada por docentes de que o conhecimento em Medicina seja autossuficiente para solucionar os problemas de aprendizagem.
} 
já mencionado anteriormente e foram inspiradas nas respostas que as docentes deram quando da testagem. Dessa maneira, a formulação da questão veio para se perceber aquilo que proporcionava uma instabilidade na docência. Vejamos alguns depoimentos em que as professoras relatam a busca por alternativas em classe, antes de buscarem um auxílio externo.

Quando o aluno repete muito. Eu dificilmente passo para terceiros... eu procuro resolver no diálogo, no conselho... Procuro ter o máximo de paciência com esse tipo de aluno [...]. (BX10)

Quando tenta de tudo o que é forma e não consegue. Quando ele não se interessa por nada! [...]. (BX4)

Hoje eu até dei uma volta. Porque exatamente o aluno que é do abrigo estava querendo, assim, tipo me enfrentar... Aí eu saí um pouco... ele fez cara feia para mim. Eu fiz cara feia para ele. Eu ainda estou conseguindo levar, sem ajuda. Eu falei: - Fala tudo o que você está querendo falar! Fala tudo! Porque você, completando a sua frase, vai levar advertência. Aí ele ficou rindo para mim, porque ele tem uma mudança de humor. Uma hora esse está meu amigo, outra hora ele está meu inimigo... Com eles eu nunca cheguei no meu limite. Este ano eu não tive problema com aluno [...]. (FX2)

(Entrevistas à pesquisadora)

No Regimento Escolar ${ }^{45}$ a advertência escrita serve como uma notificação à família ou seus responsáveis de que o aluno não está se portando adequadamente. A outra medida, em casos mais severos, é a suspensão de aulas, por no máximo três dias, com o envio de tarefas para casa. No caso mais extremo há o recurso da transferência para outra escola, o que demanda o comparecimento do Conselheiro Tutelar para examinar a situação junto à escola e os responsáveis pelo aluno. Nas escolas visitadas não observamos a adoção indiscriminada dessas medidas, o que pode ser interpretado como um avanço, na medida em que a frequência do aluno é preservada, mesmo que sob conflitos.

Em uma pergunta objetiva passível de até 7 respostas, a qual buscava saber a quem as professoras recorriam em momentos de dificuldade de aprendizagem e/ou de quaisquer esferas (disciplinares, falta de material escolar, atrasos na chegada à escola) por parte das crianças acolhidas (questão 7), obtivemos como resposta predominante a orientadora educacional e a “equipe psicopedagógica”, como disposto no Gráfico 3.

\footnotetext{
${ }^{45}$ O Regimento Escolar das Instituições Educacionais da Rede Pública de Ensino do Distrito Federal prevê tais medidas em seus arts. 53 e 54.
} 


\section{Gráfico 3}

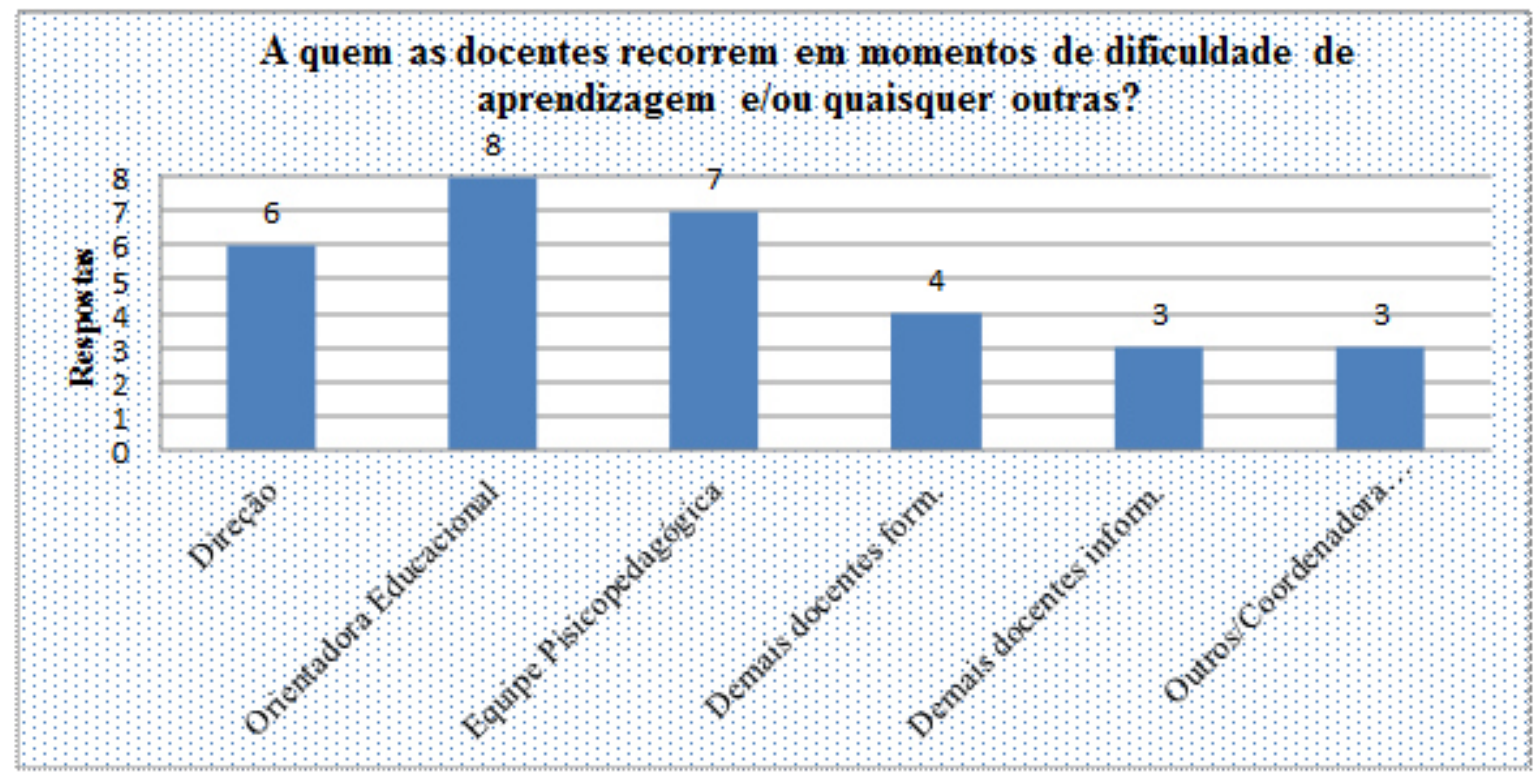

Total de 15 docentes/múltiplas respostas.

Fonte: Elaboração própria com base em dados de pesquisa. Distrito Federal, 2013.

Como podemos observar, as respostas foram pulverizadas, parecendo não haver um momento e um profissional específico com o qual todos os professores se reúnem para avaliar medidas conjuntas. A forte ocorrência de pedidos de auxílio à orientadora educacional $^{46}$ (profissional concursada e habilitada em Pedagogia) e à "equipe psicopedagógica" (profissionais docentes concursadas com formação em Psicologia e Pedagogia e selecionadas internamente para este fim) mostra que na divisão do trabalho escolar a dinâmica do papel das especialistas resulta na inviabilização do debate escolar em torno das problemáticas vivenciadas pela escola. Ainda que tais medidas venham a dar bons resultados, aquelas acabam tratadas privadamente, não sendo levadas ao coletivo na maioria das vezes.

Deve-se acrescentar que acorrer à "equipe psicopedagógica", institucionalmente denominada EEAA, significa servir-se de um aparato que guarda uma relação disciplinar com a Psicologia e com a Pedagogia que, de certa forma, repete a inserção de ambas na escola sem que se possibilite uma ampliação de outras disciplinas e profissionais na leitura dos problemas escolares e em suas repercussões na vida acadêmica dos alunos. Para a resolução ou mitigação

\footnotetext{
${ }^{46}$ Em pesquisa no Distrito Federal, Ferreira (2013) verificou que "há ainda forte demanda por uma ação do orientador pautada nas técnicas, cujo objetivo é o ajustamento ao que dele se deseja, sem uma reflexão conjunta sobre a singularidade dos alunos” (p. 73). Indicou também que tal profissional nega e afirma os pressupostos básicos que fundaram sua atuação na escola, os quais se pautam por uma negação do estudante em seus aspectos históricos, sociais e culturais, questão que torna a atuação do orientador educacional como historicamente tensionada ou conflituosa.
} 
dos problemas, há uma recorrência significativa também das docentes às demais colegas em âmbito escolar, mesmo que informalmente, sendo que apenas 6 professoras viram na direção um aparato para tais demandas. Ainda que a direção venha a saber mais adiante dos encaminhamentos de crianças à orientação educacional ou à EEAA, ela não é necessariamente participada das queixas.

Nas entrevistas, 3 professoras disseram recorrer a terceiros, tendo sido a coordenadora pedagógica a única citada. Na gravação, uma delas disse recorrer ao pai, ex-professor, embora não tenha escrito isso no formulário. Importa dizer que a coordenadora pedagógica é eleita pelo grupo de docentes e a direção eleita por voto dos segmentos que compõem a escola: os responsáveis pelo aluno, auxiliares de ensino e professores, sendo considerados os votos de alunos maiores de 12 anos. Ao analisarem os limites que percebem no trabalho das unidades de acolhimento (questão 10), no que diz respeito à resolução de questões relacionadas à aprendizagem das crianças, bem como nas questões que afetam os comportamentos dos alunos na escola, as professoras responderam que sentem limitações predominantemente na falta de profissionais, conforme Gráfico 4:

\section{Gráfico 4}

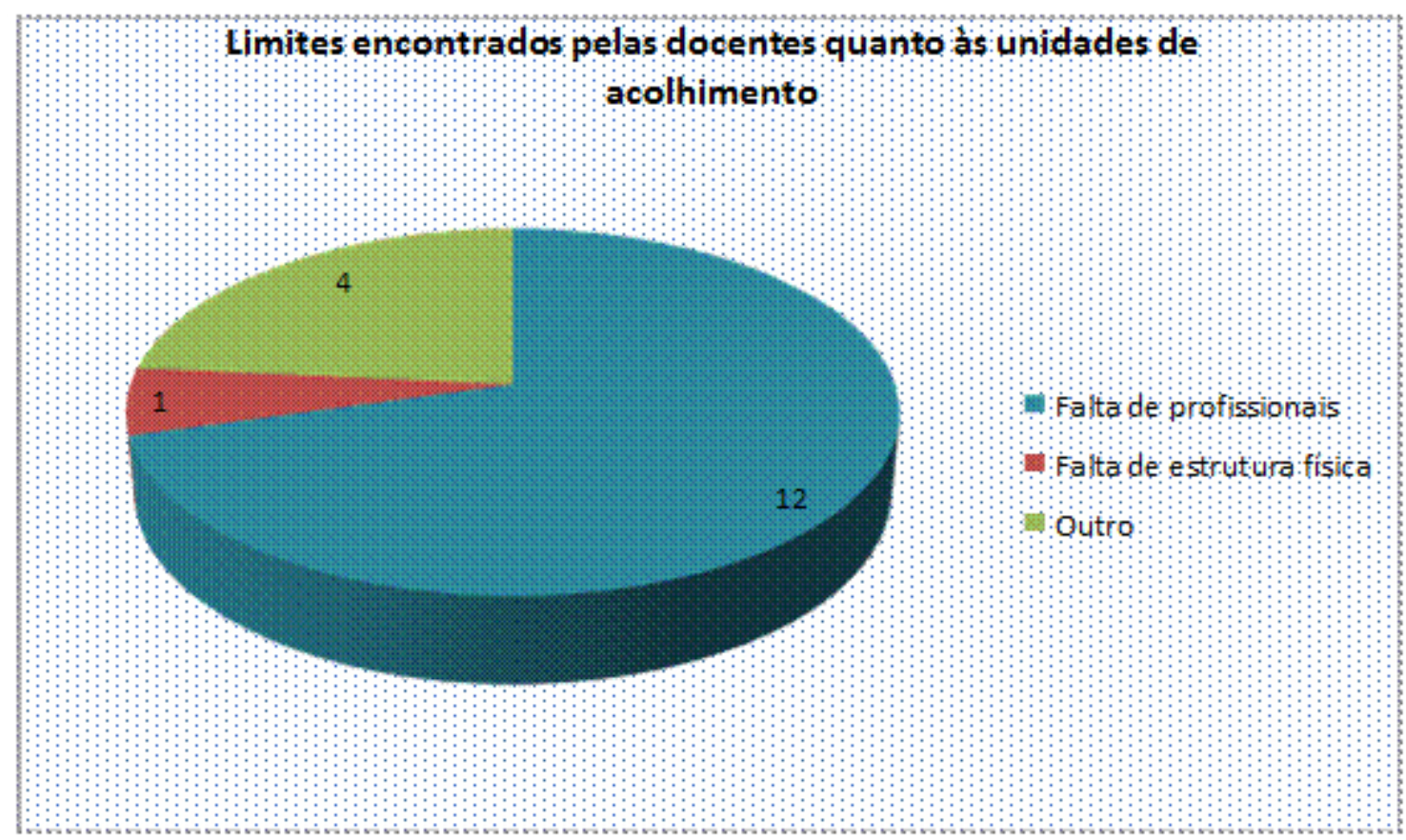

Total de 15 docentes/múltiplas respostas.

Fonte: Elaboração própria com base em dados de pesquisa. Distrito Federal, 2013.

Acrescida à ideia da falta numérica de profissionais que dessem conta de atender às demandas da unidade de acolhimento para com a escola, surgiram também, por parte dos 
docentes, as observações quanto à qualidade dos profissionais e de sua formação, tal como podemos observar a seguir:

Nem eles sabem o que fazer. Teve uma época que eu tive um menino que era terrível. Ele já era grande, tinha 12 anos no $3^{\circ}$ ano. E ele tinha uma história muito triste de vida, só que eu não conhecia a história dele. Eu perguntava, ninguém (na escola) sabia me explicar. Eu perguntava para o abrigo, eles me falavam "por cima" nas reuniões. Aí eu tive que ir lá no abrigo conversar. Fui falar com a coordenadora do abrigo. Você vai me contar a história de vida dele. Por que ele é assim? Tem um motivo! Ela me contou. Eu vi que a história dele era muito triste. Ele mudou de atitude completamente. Falta profissional preparado para lidar com as situações [...]. (BX5)

Eu acho que é na falta de profissionais, acho que na estrutura física nem tanto, mas na falta de profissionais. Quando você vai lá e relata a situação, às vezes pode demorar... (a resolução). Uma situação que aconteceu com ela é que chegou um dia aqui que ela não queria ir embora. Ela não queria ir embora, ela não queria ir embora... Ela ficou sem almoçar! Quando eu cheguei (do almoço), perguntei: - Ué, o que aconteceu que você ainda não foi embora? Ela disse: - Ah! Eu não quero morar naquele lugar não! Eu tive que conversar muito com ela. Ela disse que queria se matar. Chegou a esse extremo. Aí eu liguei lá, pedi para que buscassem ela. Aí teve um bate-boca. Não comigo, que não sou de bater boca. No outro dia conversei com ela... nunca mais a coisa se repetiu. Eu exijo disciplina, mas eu converso também. Porque eu acho que sem disciplina não acontece nada. Não acontece educação, não acontece ensino... E quando foge disso eu fico uma arara [...]. (GY2)

Lá no $\mathrm{H}$ os meninos dormem a hora que querem... Acredito que falta profissional para o reforço... Não sei se tem profissional. Eu não conheço a estrutura física de lá [...]. (BX3)

Lá... é mais na falta de profissionais. Eu sinto, assim, que eles são bem acolhidos. Vêm limpinhos, vêm com o lanche arrumadinho, só que eu acho que precisaria de uma pessoa que fosse um pouco mais ligada a essa parte de aprendizagem deles. Porque, assim, eles cuidam bem, sem problemas, mas eu acho que eles necessitam de um acompanhamento pedagógico melhor. Não seria de um professor, seria de alguém que estivesse mais próximo. Conhecer (a estrutura), eu não conheço. Eles falam. Porque tem dois abrigos aqui. Esse é bem mais... Às vezes eu pergunto: - Você gosta do abrigo? Aí eles dizem: - Gosto! Gosto! [...]. (FX2)

(Entrevistas à pesquisadora)

Não houve críticas representativas quanto à estrutura física das unidades de acolhimento. Entre as duas unidades entrevistadas, uma delas (UA1) é edificada sob a forma de casas-lares, dentro de uma estrutura condominial; e a outra (UA2), também na forma de casas-lares, mas com grandes quartos que se assemelham aos abrigos institucionais, servindo em separado a meninos e meninas. Os lares enquadrados dentro da última modalidade receberam críticas das professoras, tendo em vista que elas não situavam responsáveis individuais pelas crianças, o que deixaria as últimas sem referencial de autoridade. 
No gráfico anterior, mencionou-se a falta de profissionais nas unidades de acolhimento como um problema para a resolução de questões imediatas surgidas na escola. O exemplo da professora que chegou do almoço e encontrou sua aluna do matutino ainda na escola é emblemático da queixa quanto a profissionais com pouca mobilidade em situações de emergência. A reclamação quanto à formação de quem lida diretamente com as crianças, ou mesmo indiretamente, persistiu. A opção "Outro" contemplou tanto uma fala de quem não vê problemas na unidade de acolhimento quanto duas que fazem considerações sobre seus profissionais e gestor. Em conformidade com as Orientações Técnicas para os Serviços de Acolhimento para Crianças e Adolescentes (Otsaca), está previsto para os serviços de acolhimento:

Investir na capacitação e acompanhamento dos cuidadores/educadores, assim como de toda a equipe, é indispensável para se alcançar qualidade no atendimento, visto se tratar de uma tarefa complexa, que exige, além de "espírito de solidariedade", "afeto" e "boa vontade", uma equipe bem preparada. Para tanto, é indispensável que seja prevista capacitação inicial de qualidade e formação continuada dos profissionais, especialmente aqueles que têm contato direto com as crianças e adolescentes e suas famílias. (OTSACA, 2009, p. 25).

No formulário relativo a cada um dos 20 alunos (Anexo B), pertencentes a uma das 15 professoras entrevistadas (algumas tinham dois alunos acolhidos em classe), houve 11 respostas que consideravam inadequadas as providências tomadas pelas cuidadoras frente às queixas ou preocupações das professoras; somente 4 professoras sentiram-se satisfeitas em face das atitudes advindas de seus reclamos. Os dados constitutivos do Plano Distrital de Promoção, Proteção e Defesa de Crianças e Adolescentes à Convivência Familiar e Comunitária já dava mostras das limitações de condições em que trabalhavam as cuidadoras diretas dessas crianças nas unidades de acolhimento. No documento estava disposto que:

$60 \%$ dos profissionais recebem até 2 salários mínimos, o que é uma remuneração muito baixa para a complexidade e importância dessa função. Possuem nível de escolaridade entre Ensino Fundamental (44\%) e Ensino Médio (44\%). Relatam como principal motivação para o cargo a afinidade (27\%) e facilidade do trabalho (26\%); o desemprego e os benefícios do cargo são outros fatores de motivação. A maioria delas deixa o cargo por motivos familiares, cansaço ou dificuldade de adequação para o cargo. (MDS, 2007, p. 78).

A expectativa das professoras de encontrar um serviço de maior qualidade por parte das cuidadoras choca-se com a realidade cheia de limitações em que essas últimas se constituem como profissionais. A título de ilustração dessas dificuldades, várias professoras 
citaram que um dos abrigos entrevistados por nós anunciava a necessidade de contratação de "mães sociais" (cuidadoras-educadoras) por meio de uma faixa afixada no muro do estabelecimento, algo que viemos a confirmar indo ao local. Essa prática para arregimentar força de trabalho, em si, mostra o desprestígio do cargo e o quanto ele está cercado de precarizações, justamente aquele que deveria ser alvo de maior nível de formação, uma vez que trata de crianças que tiveram direitos violados e que estão sob medida de proteção, que estão envolvidas em tramas institucionais (família, Judiciário, acolhimento e escola) bastante complexas e por vezes antagônicas, carecendo de profissionais com uma leitura mais ampla da questão social em que se inserem.

Não se quer negar a possibilidade de que cursos eventuais se revertam em respostas favoráveis, mas a formação para os cuidados com essas crianças, em particular, sugere conhecimentos mais avançados. Ainda que as Otsaca prevejam uma escolaridade mínima de ensino médio para as cuidadoras, é necessário que se questione em que medida tão parca escolarização responde às exigências do cotidiano das entidades acolhedoras, onde as cuidadoras-educadoras precisam lidar com a domesticidade e com as atividades de âmbito escolar (deveres de casa, reuniões bimestrais na escola, buscar e levar as crianças), entre outras tantas demandas. (OTSACA, 2009).

Uma inquietação muito presente nas falas proferidas entre profissionais do acolhimento em diferentes situações e espaços de interação (questão 14) diz respeito a uma suposta estigmatização das crianças sob medida de proteção na escola. Isso ocorreria simplesmente por serem "de orfanato" ou "do abrigo". As respostas proferidas pelas professoras sobre esse assunto foram majoritariamente no sentido de negar a ocorrência (12 professoras) de estigmas dessa natureza na escola, embora o estigma racial tenha ficado presente.

Nunca existiu isso. Nada que ocorra na sala envolve ele (o aluno acolhido) [...]. (CX3)

Não, isso aconteceu uma vez! Mas foi solucionado aqui. Até ela colocou a cor dela no meio (a aluna acolhida) [...]. (GY2)

Não, por incrível que pareça, os colegas de sala de aula têm o maior cuidado com ele. Eles mesmos se disciplinaram a ter cuidado com o colega [...]. (BX8)

Não, muito pelo contrário [...]. (BX10)

$\mathrm{Na}$ verdade, um deles é negro. No final do semestre passado aconteceu de alguém falar: "Ó, neguinho!" Essa pessoa chorou e se travou! Foi um dos fatos que aconteceu. Mas foi no semestre passado. Na volta das férias, ainda não aconteceu isso. Tanto é que eu coloquei essa pessoa perto de mim. Ela 
fica bem perto de mim. Eu tenho dois negros na sala. Toda vez que acontece algo aqui na sala, eu sempre explico para eles que todo mundo é diferente [...]. (BX11)

Quando o pai descobre que a criança é de abrigo... Até você explicar o que é abrigo... Não tem que trabalhar só com os alunos, mas com os pais [...]. (BX9)

(Entrevistas à pesquisadora)

Parece haver um consenso em dizer que a escola está quase isenta de preconceitos, inclusive daqueles que marcam a história brasileira, como os etnorraciais. Possivelmente isso aconteceu em razão da danosa ideologia da democracia racial, ${ }^{47}$ que busca invisibilizar o grave quadro de usurpações raciais que marca todo o Período Republicano, onde os líderes das classes proprietárias, que davam a condução política ao país, eram em ampla maioria brancos. Apenas duas professoras admitiram que a estigmatização ocorria em classe (FX2 e BX9) e somente uma a relacionou ao fato de a criança residir em uma unidade de acolhimento, embora nas gravações as situações de estigma aparecessem com maior frequência, inclusive as relacionadas a uma suposta tendência homossexual de uma das crianças, aventada por seus pares (CX3).

Então, as poucas falas sobre estigmatização como fator de indisciplina dão conta de que, se ela aconteceu com o grupo de escola pesquisado, isso ocorreu com mais incidência no plano racial. Não se trata de afirmar que as crianças são racistas, pois são seres em desenvolvimento, apreendendo aquilo que a cultura propaga como hegemônico. Assim como não se rotula uma criança de homossexual em tenra idade, somente porque gesticula e fala de maneira distinta do esperado para o seu gênero. No entanto, pode-se esperar respeito para as crianças que são alvo de racismo e para as crianças que vivenciam a homofobia muito antes até de manifestar sua orientação sexual, sem que se esqueça de educar, por meio de debates e com afetividade, aquelas que reproduzem discursos hegemônicos de opressão.

O que não pode ser menosprezado no cotidiano escolar é que a longeva história patriarcal, racista e capitalista fundada em 388 anos de Colônia e Império escravocratas, seguidos por outros 126 de uma República elitista, em seus cinco grandes períodos

\footnotetext{
${ }^{47}$ Por ideologia da democracia racial entende-se a ideia de que o Brasil, tendo uma sociedade híbrida, mestiçada no cruzamento de grupos brancos, negros e indígenas, possibilitou uma aproximação entre senhores e escravos. A citação de Gilberto Freyre é exemplar do mito, escamoteando inclusive a opressão de gênero contida em seu bojo: "A miscigenação que largamente se praticou aqui corrigiu a distância social que doutro modo se teria conservado enorme entre a casa-grande e a mata tropical; entre a casa-grande e a senzala". (FREYRE, 2004, p. 33). Diferentes discursos e práticas consolidam o mito da democracia racial no Brasil, embora os indicadores sociais desagregados de gênero e raça tenham tornado visíveis as desigualdades sociorraciais.
} 
(República Velha, Era Vargas, República Populista, Ditadura Militar e Nova República), ainda produz impactos na sociedade brasileira, o que faz com que alguns grupos sofram mais o peso de uma história tão carregada de opressão, inclusive em termos de acesso a políticas sociais, historicamente negadas a muitos deles, como o caso do acesso da população negra à escolarização. É importante lembrar que a maioria das crianças acolhidas (58\%) é parda e preta, conforme dados da pesquisa Fiocruz (2013), e provém de estratos muito pobres, o que por si só acarreta preconceitos em um país com longeva história escravagista como o Brasil, independentemente da situação de acolhidas institucionalmente.

Quanto a publicações sobre as crianças acolhidas e as particularidades ligadas à sua aprendizagem (questão 8), buscávamos saber se as professoras tinham o conhecimento de materiais para consulta na biblioteca escolar que informassem sobre o que vem a ser o acolhimento de crianças e os possíveis entraves na aprendizagem que muitas delas poderiam vivenciar na inserção ou reinserção na escola. Todas as 15 professoras disseram não ter conhecimento de materiais dessa natureza. O que acarreta uma demanda importante para o MEC, que tem no projeto Escola que Protege um acervo para debater questões relativas aos direitos de crianças e adolescentes, o qual precisa ser mais largamente distribuído, além de mais divulgado. Por último, tratando da adequação do plano de aulas às necessidades específicas de alunos em acolhimento (questão 13) em termos das estratégias de ensino-aprendizagem, obtivemos o Gráfico 5.

\section{Gráfico 5}

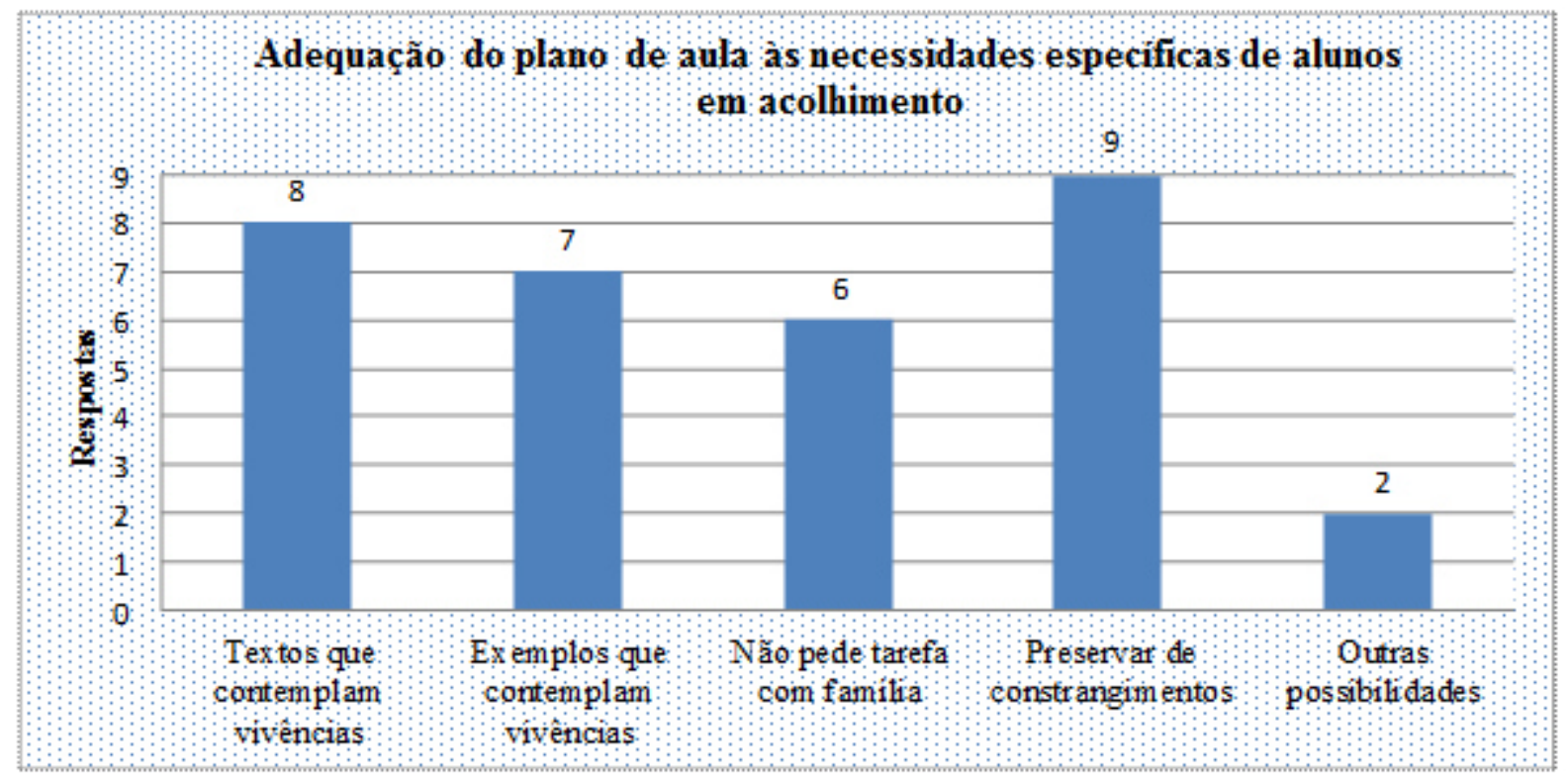

Total de 15 docentes/múltiplas respostas.

Fonte: Elaboração própria com base em dados de pesquisa. Distrito Federal, 2013. 
A pergunta atinente às estratégias de ensino não veio para se propor uma escolarização dos alunos acolhidos, fixada única e exclusivamente na própria experiência, inviabilizando-lhes a possibilidade de acessar conteúdos alheios ao seu mundo por serem "fora da realidade" que os cerca. Conforme Duarte (2011), entendemos que uma:

Pedagogia que valorize a liberdade dos indivíduos não será aquela que tenha por objetivo formar nos alunos a capacidade de adaptação à realidade local da qual eles fazem parte, mas sim aquela que forme nos alunos a consciência da necessidade de apropriação da riqueza espiritual universal e multifacetada. (DUARTE, 2011, p. 4).

Assim, interessava-nos saber das adequações adotadas para fazer os alunos se aproximarem mais dos conteúdos e dos fazeres escolares com vistas a se apropriarem com mais desenvoltura de assuntos mais distantes de suas cotidianidades. Como podemos observar, ainda se pedem tarefas que demandem às famílias recursos e até memórias familiares para sua execução. Apenas 6 professoras eximem-se de solicitar esse tipo de atividades. Ainda que muitas das crianças convivam com suas famílias em finais de semana e que a medida protetiva não trave a convivência familiar, há de se ter cuidado na solicitação de tarefas que envolvam pedidos à família, tais como fotos, receitas de bolo, plantio de sementes, escrita de livros, etc. Mesmo os familiares que mantêm visitas não necessariamente têm condições de responder a essas solicitações, fato que pode se repetir inclusive com crianças não acolhidas, em função da indisponibilidade da família por várias razões.

\subsubsection{Resultados obtidos com relação aos alunos das professoras entrevistadas}

Junto às professoras entrevistadas, buscamos saber mais sobre seus alunos em acolhimento institucional por meio de um formulário com perguntas abertas e fechadas (Anexo B). Os dados obtidos mediante as informações fornecidas pelas docentes sobre seus alunos apontam para um total de 20 alunos acolhidos, sendo 11 meninas e 9 meninos (questão 1).

Ao observarmos os resultados, podemos nos apropriar melhor das entrevistas feitas com as professoras e entender as preocupações que a escolarização desses alunos representa no contexto da medida protetiva, que se faz garantindo direitos, inclusive a uma boa escolarização. 
A maioria dos 20 alunos acolhidos matriculados nas escolas pesquisadas estava no terceiro ano de escolaridade (9 alunos), sendo 7 fora da faixa de idade adequada; 4 frequentavam o quinto ano, sendo 1 fora da faixa adequada; 5 frequentavam o quarto ano, sendo que todos estavam dentro da faixa adequada; 1 frequentava o segundo ano e $1 \mathrm{o}$ primeiro ano, ambos dentro da faixa (questão 3).

Dentro desse universo de alunos, havia, portanto, 6 alunos com 12 anos ou mais, ou seja, que já haviam entrado na adolescência (questão 2). Tomando como referência o Pacto Nacional pela Alfabetização na Idade Certa (Pnaic) ${ }^{48}$, um total de 8 alunos encontrava-se fora de faixa/ano de escolaridade/idade, o que indica acesso tardio à escola, repetência ou evasão no decorrer da escolarização (Gráfico 6).

\section{Gráfico 6}

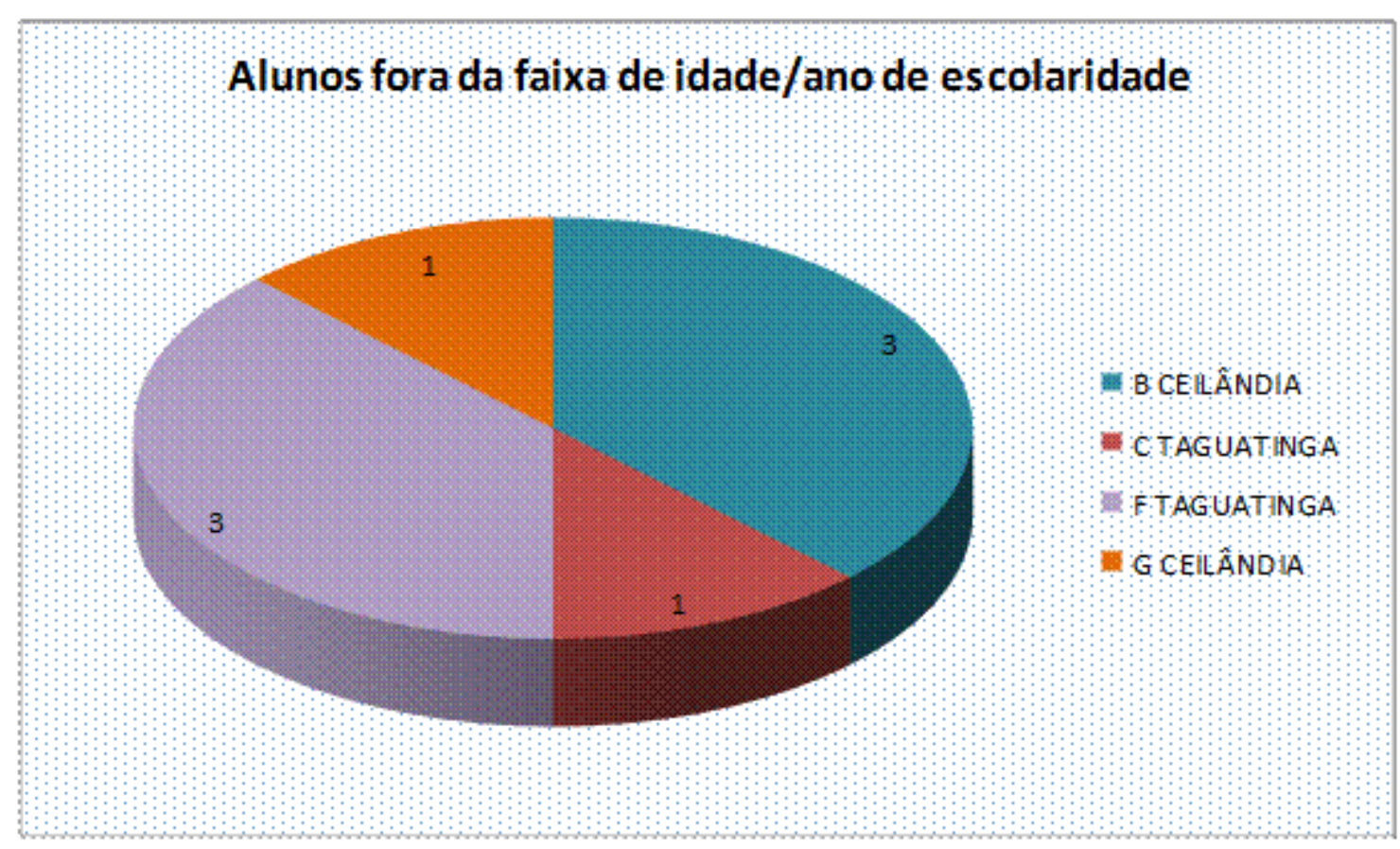

Total pesquisado: 20 alunos.

Fonte: Elaboração própria. Distrito Federal, 2013.

O Gráfico 7 mostra o desempenho dos alunos quanto à aprendizagem, segundo as docentes entrevistadas (questão 5), que atribuíram baixo aproveitamento à maioria dos alunos (11 alunos).

\footnotetext{
${ }^{48}$ Tomou-se a distorção ano cursado/idade pelo critério estipulado no Pnaic, que tem como compromisso formal assumido pelos governos federal e das unidades federativas e municípios assegurar que todas as crianças estejam alfabetizadas até os oito anos de idade, ao final do $3^{\circ}$ ano do ensino fundamental. $55 \%$ desses alunos foram considerados de baixo aproveitamento pelas professoras.
} 


\section{Gráfico 7}

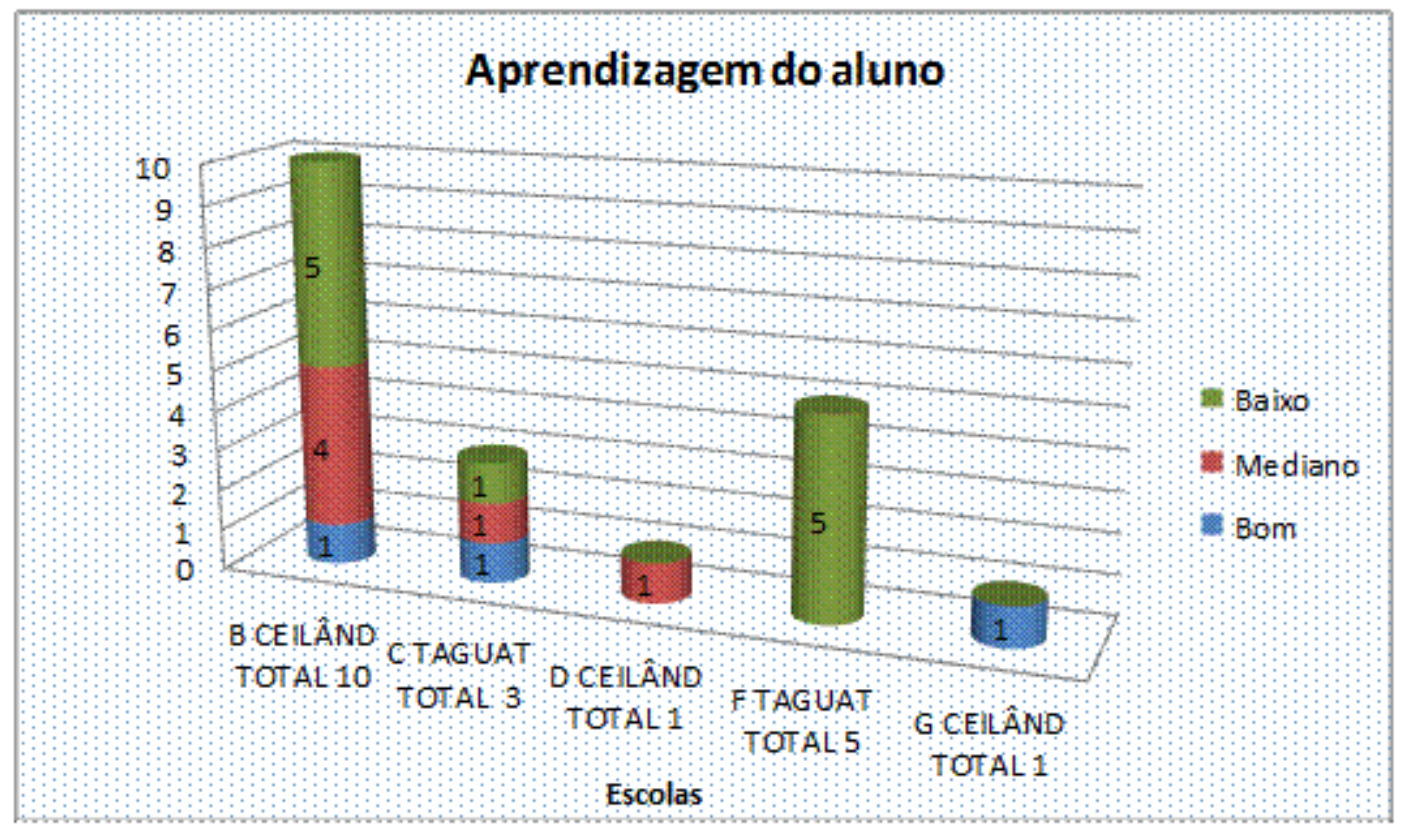

Total de 20 alunos.

Fonte: Elaboração própria. Distrito Federal, 2013.

Questionadas quanto ao encaminhamento dos alunos para a EEAA (questões 6 e 7), a maioria das professoras respondeu negativamente (12 alunos não encaminhados). Dos 8 alunos encaminhados para a EEAA, apenas 6 receberam algum tipo de diagnóstico e 2 não receberam nenhum diagnóstico.

Das 6 crianças que receberam diagnóstico da EEAA, somente 3 tiveram respostas que indicavam acometimentos: dois alunos com TDAH e um com déficit intelectivo (DI).

Questionadas se os alunos chegavam à sala de aula com dores ou mal-estar (questão 8 ), as professoras em sua maioria apontaram negativamente para o fato (7 alunos). Disseram ainda que 6 alunos raramente vivenciavam esta situação, 6 vivenciavam-na pouco e 1 vivenciava-a bastante.

Quanto aos deveres de casa (questão 9), de acordo com as respostas obtidas, a maioria das crianças não os cumpria (8) ou cumpria-os apenas parcialmente (8). Apenas 4 estudantes cumpriam totalmente os deveres.

No que diz respeito às atividades em classe (questão 11a), as docentes disseram que a maioria das crianças (9) mantinha-se dispersa durante elas. Sete mantinham-se quase sempre atentas e 4 mantinham-se atentas.

Quanto aos conteúdos ministrados em sala de aula (questão 11b), ainda na opinião das docentes, as crianças majoritariamente mostravam-se com um grau de interesse mediano (9), 
4 mostravam-se pouco interessadas, 4 interessadas mediante intervenções individualizadas e 3 mostravam-se bastante interessadas.

O interesse quanto aos conteúdos pode-se ampliar com a intervenção individualizada das professoras. Quando formulamos a questão, partimos da compreensão de que nenhum interesse sobre qualquer conteúdo ou disciplina é natural, mas que ele se engendra nas vivências culturais junto às pessoas. (LEONTIEV, 1978).

Quanto à vivência em ambiente escolar (questão 11c), a maioria dos alunos mostrou-se em adaptação (8 alunos) ou bem adaptada (10 alunos) aos usos e fazeres da escola, segundo relato das docentes. O número de estudantes não adaptados foi de apenas 2 .

Com relação à interação com os colegas de classe (questão 12), as docentes disseram que a maioria dos alunos (13) interagia bem. Seis alunos apresentavam pouca interação e apenas 1 ainda não interagia com a turma. Sobre a relação com os alunos acolhidos (questão 13), as docentes disseram ter uma relação harmoniosa com a maior parte deles (13), sendo que a relação com 4 alunos foi avaliada como "harmoniosa quase sempre" e com 3 alunos a relação foi considerada conflituosa.

Apesar de a relação ser considerada harmoniosa, na questão sobre o recebimento de advertência oral e escrita (questões 14 e 15), a maioria dos alunos já as havia recebido de suas professoras (10 alunos), embora uma minoria tenha recebido advertências escritas (2 alunos). Com relação às suspensões (questão 16), foi apontado que uma minoria havia recebido esse tipo de medida disciplinar (3 alunos).

Quanto à assiduidade dos estudantes acolhidos (questão 17), a maioria das respostas apontou que os alunos não eram faltosos (18 alunos), não havendo o fenômeno da evasão escolar nas escolas pesquisadas apesar de dois alunos terem sido apontados como infrequentes.

As professoras afirmaram sentir liberdade para falar sobre as questões escolares relativas às crianças junto às suas cuidadoras-educadoras ou responsáveis (questão 19) em grande maioria (17). Apenas com as responsáveis por 3 crianças a relação era mais dificultada. Mesmo assim, somente em relação a uma minoria de crianças (5) as docentes disseram ter conseguido respostas adequadas às suas demandas por parte das profissionais do acolhimento. Ou seja, um total de 11 crianças não foram assistidas por suas cuidadoras em conformidade com as demandas escolares proferidas pelas professoras (questão 20). A referida questão não foi respondida pelas professoras no tocante a 4 alunos. 
As docentes pouco sabem sobre os desdobramentos da medida de acolhimento na vida de seus alunos (questão 21a). Assim, elas afirmaram desconhecer a situação de 15 alunos quanto a uma possível adoção. Tinham conhecimento de apenas 3 quanto a este quesito. Quanto a 2 crianças, havia alguma informação sobre uma possível disponibilidade para serem adotadas.

Outro dado apontado nas entrevistas foi que grande parte das docentes nem sempre sabia das razões que levavam os alunos acolhidos a faltarem à escola (questão 21c). Assim, afirmaram que eram notificadas pela unidade de acolhimento a respeito do motivo da infrequência somente a respeito de 7 crianças. Por outro lado, não tinham informações sobre a razão que levava 10 crianças a eventualmente perderem o dia letivo, havendo informação parcial com relação a uma criança, sendo que duas delas nunca haviam faltado à escola.

As docentes informaram, com relação à grande maioria das crianças (16), não serem comunicadas pela unidade de acolhimento sobre a existência de família ou mesmo sobre a eventual possibilidade de visitas de familiares à escola, direito que está afirmado nas Otsaca, uma vez que o acolhimento se pauta por preservar laços (questão 21d). Dentre as demais crianças, havia alguma informação sobre duas no que diz respeito à família e visitas. Somente com relação a duas crianças havia conhecimento satisfatório, por parte das docentes, do que ocorria em termos do andamento de suas vidas familiares.

As professoras não sabiam informar da motivação que levara ao acolhimento da grande maioria dos seus alunos, ou seja, 14 deles; tendo essa informação a respeito de apenas 6 crianças (questão 21e).

Por meio de tais informações percebemos que as professoras sabem pouquíssimo dos alunos: dos motivos que os levaram ao acolhimento, das razões pelas quais faltam à escola eventualmente, ou se suas famílias podem visitá-los na escola ou se perderam o vínculo com elas e estão aguardando adoção. Há uma cultura de silêncio muito arraigada em torno dos processos que levam à medida protetiva ou que a mantêm. Acreditamos que ela seja danosa para o encontro entre professoras e alunos, devendo ser pauta de debate, entre outros fóruns, por todos os conselhos, profissionais ou não, implicados na condução do acolhimento, a fim de que novas mediações permitam uma relação mais produtiva entre docentes e discentes.

As docentes informaram-nos que a maioria das crianças (14) já foi encaminhada para orientação educacional, o que situou problemas de ordem disciplinar, ratificando que as atribuições do orientador educacional dizem respeito a identificar e prevenir conflitos, entre 
outras. Quatro alunos não passaram por esse serviço e não houve informação sobre outros 4 por parte das professoras (questão 22).

Um ponto que nos chamou a atenção foi a opinião docente sobre o papel da escola na vida acadêmica dos alunos abrigados.

O papel predominante da escola na vida de 14 alunos, segundo as professoras, é o de "acolhedora", exercendo, portanto, com menos ênfase o seu papel como espaço de aprendizagem (questão 24). A escola só teve esse papel para 5 estudantes, havendo uma professora que não se pronunciou por nenhuma das duas alternativas quanto ao seu aluno. Não se trata de recusar o importante papel de socialização da criança por parte da escola, mas de evidenciar a dispersão dos objetivos escolares. A indagação foi inspirada em um estudo de Libâneo (2012), que afirma existir um dualismo na escola pública brasileira que vem se agravando, caracterizado por uma escola do conhecimento para os ricos e por uma escola do acolhimento social para os pobres, onde se realizam as aprendizagens mínimas à sobrevivência. Isso quer dizer que se trata de uma escola que minimiza o seu papel de agente na formação intelectual do discente, com vistas à sua inclusão escolar "em detrimento do acesso à cultura e à ciência acumuladas pela humanidade". (LIBÂNEO, 2012, p. 23). No entanto, o autor acredita que a inclusão social somente se concretiza quando o aluno aprende para além do mínimo, daquilo que garante a mera sobrevivência. O papel de acolhedora por si só não garante essa possibilidade.

Destinamos a pergunta em especial para o grupo de crianças acolhidas, tendo em vista que as pesquisas anteriormente estudadas por nós falavam bastante de um mau aproveitamento escolar por parte deles, o que nos fez refletir sobre a qualidade da estada dos alunos em sala de aula. Importa dizer que mesmo o papel de "acolhedora" vem sendo feito de maneira equivocada, haja vista os vários relatos de situações desconfortáveis vivenciadas por crianças acolhidas nas escolas.

As professoras ficaram livres para relatar impressões do ponto de vista físico ou emocional sobre seus alunos por meio de uma questão aberta (questão 25). Obtivemos como resposta diferentes constatações que as inquietavam: a orfandade das crianças, a violação sexual, a vivência na rua, o medo de relacionamento com adulto, o racismo que sofriam, a timidez, a carência de diálogo, a suposta tendência homossexual que podia ser rechaçada, o choro repentino, a mudança de humor, a memória familiar presente, a carência afetiva, a sonolência por causa de medicamento que tomavam, a tristeza e a pouca participação na escola. Ou seja, as professoras são instadas a pensarem nas crianças e seus problemas sem necessariamente conhecê-las mais amiúde. Trata-se, neste sentido, de uma relação quase 
residual, um pouco mais que um retalho de vínculo humano. Por estarmos dissertando sobre os anos iniciais do ensino fundamental, onde a relação diária entre uma única regente com seus alunos, acolhidos ou não, é bem mais prolongada, surge a questão de como se estabelece essa cotidianidade relacional nos anos finais, em que o dia letivo é compartilhado por um número maior de docentes, por meio de aulas que revezam diferentes componentes disciplinares.

\subsection{As entrevistas com gestoras}

Tal como foi explicado anteriormente, a entrevista realizada com as gestoras foi elaborada de modo a obter um substantivo material de análise, a fim de que compreendêssemos melhor suas impressões acerca do trabalho com os alunos em acolhimento institucional e suas trajetórias escolares. O formulário utilizado como instrumental de coleta de dados (Anexo C) foi composto por perguntas de caráter objetivo e subjetivo, contabilizando um total de 45 questões. Foram entrevistadas as cinco diretoras (gestoras) das escolas Bege, Carmim, Dourado, Ferrugem e Grená, anteriormente elencadas. Sabíamos, desde o início, que não seria possível proceder à análise de todas as respostas individualmente, mas consideramos importante investir na coleta desta rica fonte de informações para que posteriormente pudéssemos recortá-la conforme nossas preocupações fossem se refinando, ainda no decorrer da etapa do trabalho de campo e posteriormente, quando das primeiras explorações dos dados obtidos.

Neste sentido, categorizamos as nossas preocupações quanto à permanência escolar de crianças acolhidas em seis aspectos, dentre os quais extraímos do formulário exclusivamente as perguntas/respostas que mais os contemplavam na entrevista semiestruturada, delimitando uma significativa porção do corpus de nossa pesquisa. Os aspectos escolhidos foram os seguintes:

1) Quanto ao conhecimento pelas gestoras dos aspectos legais contemplados no ECA.

2) Quanto à articulação da escola com outras instituições.

3) Quanto ao PPP da escola e da instituição.

4) Quanto às medidas frente à indisciplina dos alunos.

5) Quanto à percepção dos alunos pelas gestoras.

6) Conhecimento específico quanto ao acolhimento.

Naquilo que tange ao conhecimento do ECA, arts. 53, 56, 98 e 101, os quais respectivamente dizem respeito ao direito à educação, à responsabilidade dos estabelecimentos 
de ensino fundamental em comunicar casos específicos ao CT, às medidas de proteção e ao acolhimento institucional: à exceção da escola Grená, todas as direções escolares mostraram ter conhecimento dos artigos em questão, o que pode ser considerado positivo, embora o simples fato de saber da existência da legislação não implique a efetivação do direito (questões 1 e 2). Uma gestora afirmou não conhecer o Estatuto, o que prejudica o entendimento do que é o acolhimento e do que a escola sob sua direção pode fazer em benefício de quaisquer alunos, não somente os acolhidos. Tal desconhecimento sugere que ainda há a necessidade de maior preparo das pessoas que ocupam o cargo de direção, algo que pode ser feito no decorrer do seu mandato, a fim de que a escola e seus profissionais não incorram em erros ou abusos ${ }^{49}$ e redimensionem a compreensão dos alunos como sujeitos de direitos.

Um dado importante diz respeito à frequência diária das crianças à escola. Neste sentido, nenhuma das escolas pesquisadas apontou infrequência por parte dos alunos. Sua permanência, assim, estava assegurada, informação que corresponde àquelas fornecidas pelas professoras. Com relação ao total de alunos acolhidos institucionalmente, a escola Bege foi a que apresentou maior número de crianças nessa condição. Os estudantes estavam distribuídos por quantidade: a escola Bege com 18, a Carmim com 7, a Dourada com 3, a Ferrugem com 3 e a Grená com apenas 1.

E foi na escola Bege que obtivemos maior concessão de entrevistas por parte das professoras. O estabelecimento de ensino $\mathrm{F}$ tinha alunos acolhidos que não eram do conhecimento das próprias gestoras (diretora e vice-diretora). Somente ao iniciar a entrevista junto àquelas professoras apontadas como regentes desses alunos é que a entrevistadora foi interpelada por outras docentes que tinham em suas salas de aula alunos nesta condição, as quais se mostraram surpresas por não terem sido convidadas para as entrevistas, afinal, em razão de outros compromissos, não estavam na escola no dia em que a pesquisadora ali se apresentou com a proposta de pesquisa. Travado o contato inicial, verificamos a disponibilidade daquelas que tinham alunos entre o $1^{\circ}$ e o $5^{\circ}$ ano de escolarização e marcamos os horários das entrevistas para aquelas que se dispuseram a tanto.

O evento narrado anteriormente mostra haver um alheamento por parte do trabalho da gestora na sua atuação como integrante do Sistema de Garantia de Direitos (SGD),

\footnotetext{
${ }^{49}$ Chrispino e Chrispino (2008) abordam o desconhecimento por parte dos profissionais da escola sobre a legislação que protege crianças e adolescentes, mostrando as graves consequências que isso acarreta em seu interior, o que vem repercutindo em judicializações. Ainda que as alternativas propostas pelos autores para dirimir a problemática não sejam partilhadas por nós em sua integridade, entendemos que a compreensão dos direitos garantidos em lei é política e precisa ser sempre renovada com capacitações, cursos e afins, para que a judicialização das relações escolares não seja uma realidade inabalável.
} 
particularmente no eixo que diz respeito à promoção do direito à educação, em especial de crianças com grandes probabilidades de insucesso na escola, algo evidenciado inclusive nas Coordenações Regionais de Ensino de Taguatinga e Ceilândia, que não possuíam as listagens das escolas que atuavam com crianças acolhidas, o que justificou a nossa peregrinação para identificar as unidades de ensino com essas características.

Sobre o SGD é possível dizer que a sigla não mereceu qualquer referência em nenhuma das entrevistas realizadas por nós. Embora as docentes saibam do direito das crianças à educação, ainda não há uma compreensão por parte delas de que o aluno esteja tecido em uma malha de outros direitos, que deveriam assegurá-lo e fortalecê-lo. Ao serem indagadas sobre as características positivas dos alunos acolhidos (questão 8), as respostas das gestoras não se deram em um plano que contemplasse as aprendizagens, ou seja, a dimensão cognitiva, conforme o Gráfico 8.

\section{Gráfico 8}

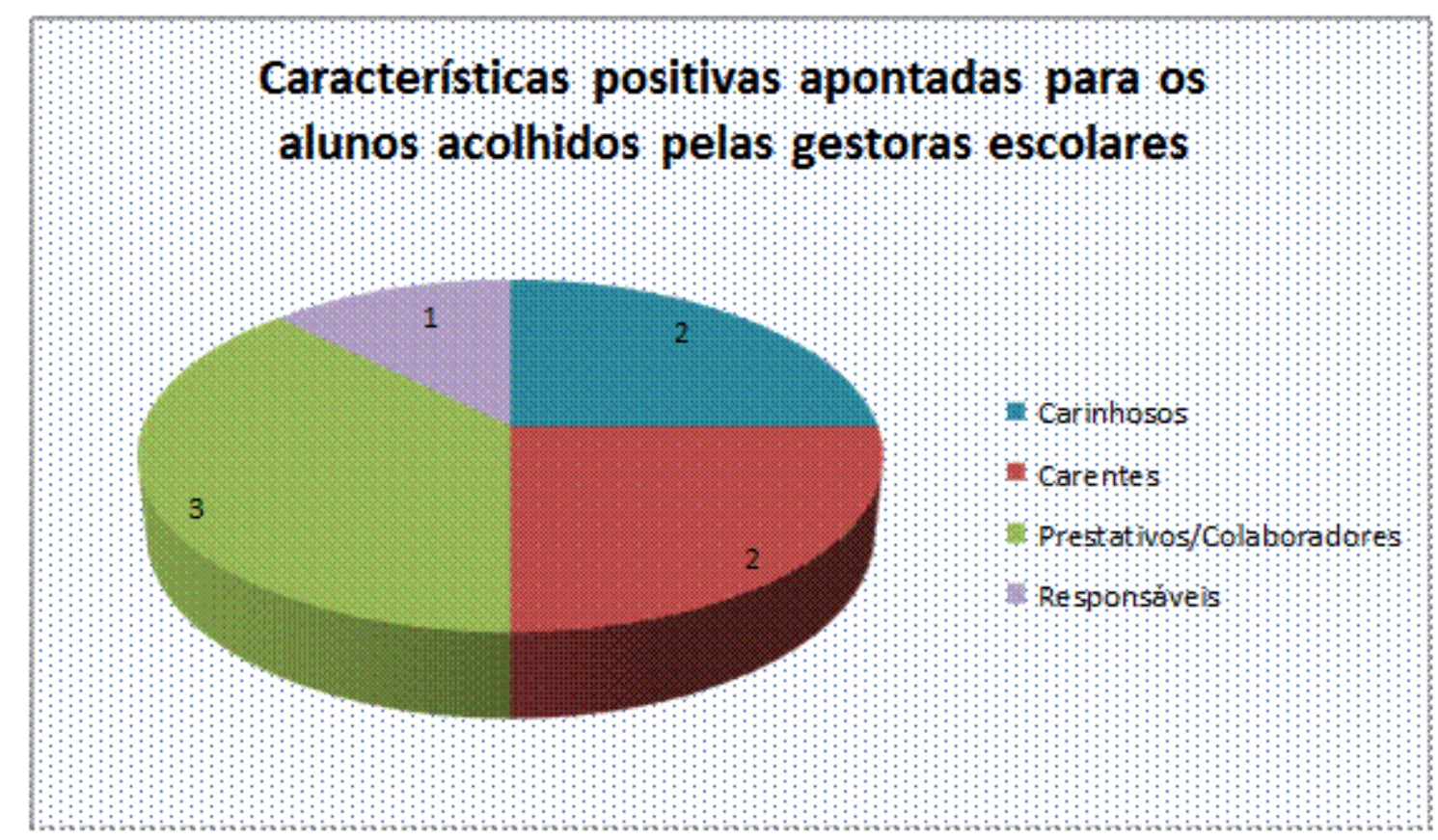

Elaboração própria com base em dados de nossa pesquisa. Distrito Federal, 2013

Estes dados apontam para uma repetição de características mais focadas em aspectos da urbanidade (prestativos, participativos e colaboradores) e os de ordem afetiva (carinhosos e mostram a carência que têm), havendo lacunas sobre as características ligadas ao desempenho mais estritamente intelectual das crianças. Um olhar que coincide com aquele das professoras entrevistadas. Por outro lado, as gestoras, ao terem uma visão do todo escolar, acabam por 
apresentar percepções que as professoras individualmente não apresentaram, tal como exemplificado no trecho transcrito a seguir:

As crianças menores do abrigo são muito carinhosas, as menores. São carentes, elas vêm, abraçam e beijam, são muito carinhosas. Alegres. Os mais novinhos. Agora, os mais velhos já não são. Os mais novos têm mais interesse na escola. Eles gostam de participar mais das atividades. Os mais velhos [...], nós temos 3 crianças abrigadas no $5^{\circ}$ ano. Eles já não são assim! Eles já dão mais problema de comportamento, de relacionamento. [...] À medida que eles vão crescendo, já vai mudando a coisa.

(CX1 - Entrevista à pesquisadora)

As crianças do $5^{\circ}$ ano estão na faixa dos 10 anos ou mais, caminhando para maior autonomia, conforme a expectativa cultural, aproximando-se daquilo que se espera para um adolescente. Reiteramos que não se trata de uma mudança ocasionada por aspectos biológicos, de ordem hormonal, por exemplo. Referimo-nos às agências promovidas pelas vivências socioculturais. Conforme sugere Facci (2004), acontece uma mudança na posição do adolescente frente ao adulto, de modo que:

As suas forças físicas, juntamente com seus conhecimentos e capacidades, colocam-no, em certos casos, em pé de igualdade com os adultos, e, muitas vezes, até superior em alguns aspectos particulares. Ele torna-se crítico em face das exigências que lhe são impostas, das maneiras de agir, das qualidades pessoais dos adultos e também dos conhecimentos teóricos. Ele busca, na relação com o grupo, uma forma de posicionamento pessoal diante das questões que a realidade impõe à sua vida pessoal e social. A adolescência é o período de desenvolvimento mais crítico e, nessa idade, segundo Elkonin (1987), essa atividade especial no estabelecimento de relações pessoais íntimas entre os adolescentes é uma forma de reproduzir, com os companheiros, as relações existentes entre as pessoas adultas. (FACCI, 2004, p. 71).

O processo observado anteriormente pode ocasionar conflitos em sala de aula, independentemente da condição dos alunos, acolhidos ou não. Deve-se frisar que o acolhimento institucional propicia uma vivência entre crianças em idades muito distintas e também com adolescentes, o que pode fazer com que manifestem mais cedo relações e formas de agir típicas destes últimos. Quantos às dificuldades e problemas recorrentes em alunos acolhidos e não acolhidos (questão 9), vimos, conforme o Gráfico 9, a preocupação com o bullying se sobressair nos depoimentos das diretoras em resposta à questão. 


\section{Gráfico 9}

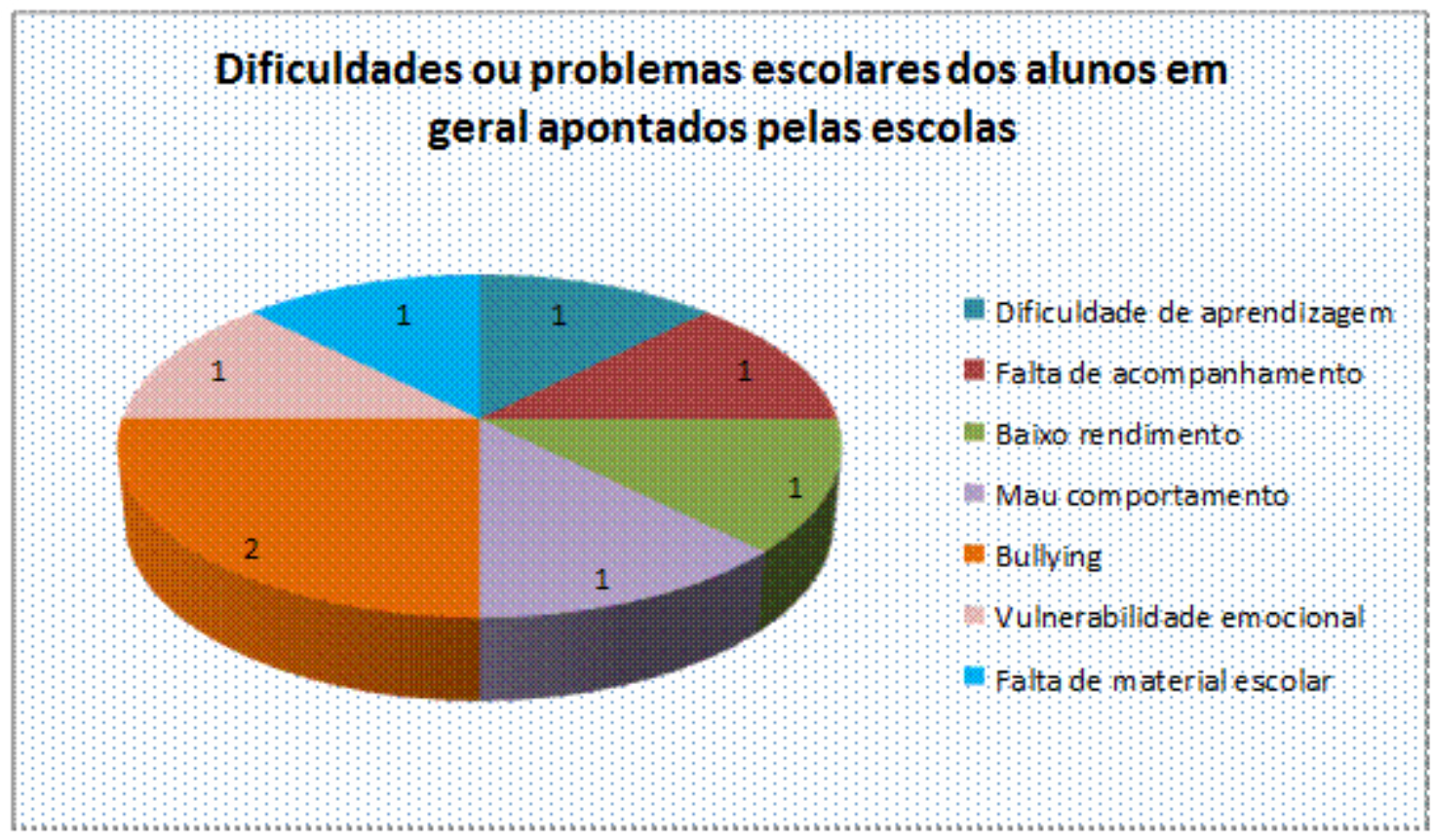

Elaboração própria com base em dados de nossa pesquisa. Distrito Federal, 2013.

O termo em inglês, sem tradução direta em português, que indica intimidação ou agressão, é bastante difundido nas escolas, graças a publicações em revistas e em matérias jornalísticas da televisão. A partir de pesquisa relacionada ao tema, Campos e Jorge (2010), depois de entrevistarem 107 professores em Natal (RN), afirmaram que:

É da televisão que vem o conhecimento que eles detêm, assim como acontece com a maioria das informações na atualidade. Somando os entrevistados que responderam "televisão" com os que se reportaram a "jornais e revistas", as respostas chegam a quase $41 \%$, o que demonstra a presença do fenômeno bullying nos meios de comunicação, ou seja, a mídia está voltando suas atenções para o problema. (CAMPOS; JORGE, 2010, p. 120).

Frente à disseminação de tantos materiais sem aporte científico crítico sobre o assunto, que o tratam superficialmente e apenas em seus efeitos, mas que medeiam informações a partir das redações para a categoria de professores, buscamos pensar a violência na escola a partir da constituição de nossa sociedade. Assim, levamos menos em conta a cena de intimidação e agressividade entre um e outro aluno, por ela portar um caráter restrito da problemática, e levamos mais em conta considerações como as que foram feitas por Francisco e Libório (2011), que buscaram alargar o espectro de relações que se postam em torno do bullying:

Poderíamos contribuir para a superação de uma compreensão individualizante desse fenômeno social, como se somente o agressor e a 
vítima fossem responsáveis pela sua ocorrência, sem considerar a força dos valores e crenças culturais, que inspiram práticas pouco empáticas e solidárias entre os sujeitos de nossa sociedade de forma mais ampla. (FRANCISCO; LIBÓRIO, 2011, p. 65).

Esses valores e crenças, que não se abrem para uma existência mais cooperativa e humana, estão ancorados numa sociedade carregada de desigualdades, particularmente econômicas. Saviani aborda que, em uma sociedade estruturada em classes, a violência está sempre à espreita. E alerta:

Devemos, pois, considerar que o status de violência instalada que define a sociedade atual se manifesta tanto na violência potencial ou real, cuja forma mais acabada concentra-se na instituição estatal, como de maneira indireta na violência decorrente do caráter alienante e explorador das relações sociais. É a violência como modo de vida que afeta, de modo extremo, uma horda de miseráveis, famintos, moradores de rua, usuários de drogas, afetados pela prostituição e diferentes tipos de enfermidade, atingindo, embora de modo menos visível, todos os trabalhadores submetidos a condições precárias de trabalho, de saúde, de educação, atormentados pelo fantasma do desemprego e subemprego. (SAVIANI, 2013, p. 40).

Não se pode esperar que, em uma sociedade erguida sobre tantos dispositivos de violência física, psicológica ou simbólica, o aparato escolar não se reverta em um canal de expressão de insatisfações, de opressões (raciais, de gênero, de orientação sexual, de classe, de origem regional, etc.), de usurpações de toda ordem entre os alunos. Afinal, os muros da escola não dão conta de afastar a realidade que os tornou uma necessidade: a propriedade privada. A propriedade privada que está na base do conflito de classes, e que se torna pivô de pequenas e grandes violências, inclusive, dentro das instituições públicas como a escola.

Dessa maneira, quaisquer abordagens preventivas ou mitigadoras do chamado bullying $^{50}$ que não levem em conta as bases sociais em que ele aparece como fenômeno carregam-se de um viés idealista. A violência é legalidade social em uma sociedade de classes. Está no plano das universalidades, tendo no Estado um dos seus maiores executores. A escola pode minimizar as situações em que os alunos se digladiem, mas não poderá sanar o problema como um todo, pois o corpo funcional da escola é também, como informam Campos e Jorge (2010), agente de constrangimentos frente aos alunos.

\footnotetext{
${ }^{50}$ Concordamos com Francisco e Libório (2012), em citação de Francisco (2013), ao afirmarem que o conceito de bullying carrega atrás de si um esvaziamento de conceitos e do papel de movimentos sociais em torno da questão racial e da homofobia por uma agência do próprio capitalismo. E também com a ressalva de ambos: "É importante deixar claro que não estamos defendendo que não existam pessoas que sofram perseguições constantes e repetitivas, o que desencadeia situações de bullying, todavia precisamos demarcá-lo de maneira mais clara para que não seja difundido como um conceito relativista". (FRANCISCO; LIBÓRIO, 2012a, p. 4).
} 
Ao entrevistarmos as gestoras, esperávamos delas uma visão de conjunto, mais ampla, graças à divisão do trabalho escolar. A divisão do trabalho escolar permite que essas profissionais conheçam todas as turmas e tracem um perfil panorâmico, mesmo que limitado, do que ocorre na escola, inclusive em termos de problemas e dificuldades que incidem entre os alunos acolhidos de todas as turmas da escola. A questão 10 referiu-se aos problemas escolares percebidos com mais destaque em relação aos alunos acolhidos pelas gestoras. As alternativas para ela foram construídas a partir do pré-teste e também inspiradas na literatura a que tivemos acesso. A expectativa era que a direção escolar mostrasse os impeditivos para que as crianças levem a cabo a sua escolarização.

A análise das respostas permitiu-nos constatar que a não realização do dever de casa é uma constante reclamação entre as gestoras, somente menos representativa que a agressividade e indisciplina em classe dos alunos em acolhimento, algo que contrasta e contradiz com o espírito de colaboração e de prestatividade anteriormente colocado para esses alunos. O relato de duas gestoras sobre problemas percebidos junto aos alunos abrigados, transcrito a seguir, pode dar respostas importantes sobre o que acontece em sala de aula.

Carência afetiva. Eles requerem uma atenção toda especial, por serem de lá. Não dá para dar essa atenção todo dia. Principalmente o professor. Nós que somos de fora (da direção), quando a criança vem, quando o professor manda, a gente tem um trato diferente para falar, justamente porque a gente sabe que atrás daquele comportamento tem alguma coisa. Mas o professor em sala não tem tempo disso não! [...]. (CX1)

Aqui na escola a gente tem muito cuidado com o que pode provocar bullying. Uma fala aqui na escola com relação a um aluno pode ser uma fala que eles vão usar eternamente para prejudicar o outro na hora do recreio, na hora da saída [...]. (DX1)

Violência, agressividade, tem um que bate em todo mundo. Indisciplina! [...]. (FY1)

O único caso de transferência que a gente teve foi o do ano passado. Dessa criança que eu te falei. Nesse caso entramos num acordo! Dois anos e meio que vinha apresentando isso. Mas o ano passado nós chegamos no limite. Porque chegou ao ponto de ofensas físicas, agressão física, agressão verbal. Aí fizemos um acordo com o abrigo. Nesse caso, não seguimos o regimento à risca. Foi um acordo, para não ter que expor como transferência, expulsão. Eles também acharam bom, porque não estava dando certo aqui [...]. (CX1)

(Entrevistas à pesquisadora)

Nos relatos das professoras, as situações de agressão entre alunos não foram narradas com o detalhamento daqueles proferidos pelas diretoras. Remetemo-nos, por isso, à discussão feita sobre a violência nas escolas denominada bullying. Se não é possível eliminar as bases que tornam a violência uma continuidade em nossa sociedade, é importante pensar na escola 
como local de acolhida, como comunidade que recebe a diversidade, para que se promova um bem-estar maior entre as crianças. Em nenhuma das cinco unidades de ensino ouvimos falar de um preparo para o recebimento das crianças, tal como se orienta fazer nas unidades de acolhimento logo no momento da entrada das crianças.

As escolas públicas do Distrito Federal contam com orientadoras educacionais em sua grande maioria, que podem, desde que devidamente informadas sobre as narrativas dessas crianças, proceder a um protocolo-padrão de acolhida junto ao corpo docente, funcionários e direção. Muitas dessas crianças chegam à escola com o ano letivo iniciado, tendo perdido, além de muitos dias de aula, a própria construção da dinâmica de funcionamento da sala de aula e da unidade de ensino. Recentemente submetidas à medida de proteção, algumas dessas crianças viveram situações bastante adversas, vindo a ingressar em uma escola que lhes é completamente estranha. Ou seja, se não há um apresto logo que a matrícula se efetiva, não há uma recepção que faça o aluno se sentir como possível membro da comunidade escolar, o que faz com que acabe por ser um estranho na unidade de acolhimento e na escola.

Quando as crianças que vivem junto às suas famílias chegam à escola fora do início do ano letivo, recebem de seus pais algum nível de preparo para lidar com a novidade. Em relação aos alunos das instituições de acolhimento, no entanto, repetidas vezes durante as entrevistas ouvimos, inclusive dos secretários escolares, que a matrícula era feita burocraticamente, com escassez de dados, sendo inseridos em classe, imediatamente após esse breve procedimento. Entendemos que a permanência escolar com aprendizagem diz respeito, dentre outras coisas, a uma construção de condições que levem as crianças provenientes de situações adversas em alto grau a se agregarem às demais, mediante intervenções planejadas. Para tanto, as unidades de acolhimento deveriam municiar a escola de informações que a subsidiem nesse esforço de agregação.

Reiteramos que a escola não se constitui de um espaço de todo harmonioso, pois a sociedade na qual está inserida não tem condições de sê-lo. Entretanto, ela pode estar mais atenta a situações aversivas passíveis de ser contornáveis via PPP e outros dispositivos. Todo esse esforço em preparar crianças para um novo ambiente escolar nem sempre é vitorioso, mas tem como intuito evitar, por exemplo, a não adaptação de uma criança com dois anos e meio de estadia na escola, a ponto de precisar sair do estabelecimento mediante acordo, tal como nos foi exposto nas entrevistas.

Outra questão identificada junto às gestoras foi a recorrência de reclamações por parte das professoras quanto à não realização dos deveres de casa, problemática que 
somente pode ser sanada interinstitucionalmente, tendo em vista que é preciso saber as condições oferecidas às crianças nas unidades de acolhimento para a execução de tais tarefas, como o estabelecimento de rotina, tranquilidade, material à disposição, entre outros aspectos. Em resposta à questão 11, sobre possíveis problemas com relação aos acolhidos não aventados no formulário, a carência afetiva, já abordada anteriormente pelas professoras, aparece novamente nas informações das gestoras como um dado relevante (por duas gestoras entre cinco).

Como já mencionado, o problema de carência afetiva deve ser visto no conjunto da escola e sua capacidade de propiciar eventos que renovem as potencialidades afetivas e intelectuais das crianças simultaneamente. O adoecimento das crianças acolhidas (duas gestoras entre cinco) aparece como um dado novo na fala das gestoras, não observado anteriormente pelas professoras de maneira isolada. Nas narrativas das gestoras há menção a recorrentes situações nas quais as crianças chegam à escola em adoecimento, sequer podendo concluir o turno, problema que causaria muitos transtornos para essas últimas e para as docentes, que reiteradas vezes precisam aguardar o comparecimento dos responsáveis pelas crianças, sendo esse processo muitas vezes demorado, permeado por atrasos.

Nos casos elencados pelas entrevistadas, as unidades de acolhimento são bastante próximas das escolas, o que causa às gestoras uma impressão de desídia por parte das instituições, ainda que seus profissionais compareçam à escola para buscarem as crianças com tardar. $\mathrm{O}$ atrito entre escola e unidade de acolhimento fica evidente à medida que esta última responde pela criança, mas não atende ao seu chamado dentro de um tempo considerado tolerável. Em seu art. $5^{\circ}$, o ECA prevê que as crianças ou adolescentes não poderão ser objeto de qualquer forma de negligência, discriminação, exploração, violência, crueldade e opressão, seja por ação ou omissão de seus direitos fundamentais, sob pena de punição na forma da lei.

Neste sentido, nenhuma das escolas referiu-se explicitamente a uma situação de negligência, mas afirmou que há abusos das unidades de acolhimento na medida em que enviam crianças com acometimentos para a escola e demoram a efetuar o socorro. Em geral, como pudemos apreender nas entrevistas, a resposta para a demora dos profissionais do abrigo em buscar as crianças adoentadas refere-se à falta de condições de deixar outras crianças sozinhas na unidade, entre outros fatos ligados à domesticidade, bem como a falta de veículo que transportasse o aluno da escola para o hospital, realidade que aponta para a precariedade do serviço de acolhimento. Cabe ressaltar que em nenhuma das escolas vimos o Conselho Tutelar ser acionado para mediar essa problemática. 
Diante do questionamento quanto ao planejamento conjunto de atividades entre escola e unidade de acolhimento (questão 14), as 5 gestoras afirmaram que esse tipo de encontro ainda não acontecia, o que se apresenta como uma problemática interinstitucional, tendo em vista que muitas das realizações da escola dependem do conhecimento, da colaboração e da anuência da unidade de acolhimento. A realização dos deveres de casa, anteriormente citados, é exemplo dessa necessidade. Os trechos transcritos a seguir explicitam a demanda por um PPP que preveja um trabalho conjunto:

Especificamente abrigo, não! A gente não cita no PPP. A gente faz em geral. A gente não fala especificamente deles [...]. (BX1)

É uma coisa a se pensar. Nós estamos construindo o PPP agora [...]. (FY1)

Para o abrigo, não! Só para a escola em geral [...]. (GX2)

(Entrevistas à pesquisadora)

Ou seja, a previsão no PPP de uma aproximação entre escola e abrigo é uma tarefa a ser feita em nome de uma interação mais profícua. As escolas mostraram-se interessadas pela possibilidade de um planejamento conjunto, ainda que essa venha a ser mais uma obrigação dentre as tantas que vêm acumulando no processo de democratização do acesso escolar. Quanto à previsão de medidas garantidoras da permanência escolar entre unidade escolar e de acolhimento (questão 15), o termo "garantia" foi empregado no sentido de uma oferta de condições que proporcionasse uma estada mais consolidada e com mais efetividade por parte das crianças na escola. Tal esclarecimento foi devidamente realizado no momento da entrevista. Entre as cinco gestoras, apenas a responsável pela escola Bege disse possuir medidas dessa natureza: “[...] Nós colocamos lá (no PPP) as reuniões periódicas, porque, quando chegamos aqui, fomos informados dessa dificuldade com o abrigo [...]”. (BX1 Entrevista à pesquisadora)

Observamos que, mesmo tendo previsto a realização de reuniões com a unidade de acolhimento no PPP, a escola não vem realizando reuniões de planejamento pedagógico em conjunto com o abrigo, conforme foi apontado na questão anterior.

O Conselho Escolar, como instância decisória da escola, tem um importante papel a desempenhar no sentido de torná-la efetivamente pública. Neves (2006) aborda em seu estudo sobre Participação Popular e Orçamento Participativo que há um campo de disputa entre os projetos neoliberal e democrático-popular na apropriação do conceito de participação. Quando mencionamos a importância dos Conselhos Escolares, temos em vista uma ampliação do sentido público da escola, mais aproximado daquilo que representou o projeto 
democrático-popular. Assim, quando enfatizamos a importância da participação de conselheiros escolares na gestão escolar, entendemos que "a busca da democratização do Estado e da sociedade civil e a ênfase no discurso da participação são relevantes para que se venha a efetivar a construção desses espaços públicos”. (NEVES, 2006, p. 29).

A elaboração da questão quanto ao assento no Conselho Escolar da unidade de acolhimento (questão 17), mais do que esperar uma resposta positiva ou negativa, teve como intuito problematizar a possibilidade de haver uma representação por parte dos dirigentes do acolhimento em uma das cadeiras do conselho. Afinal, muitas unidades de acolhimento têm mais de uma dezena de crianças matriculadas em uma só escola.

Todas as respostas à questão foram negativas, mas as cinco gestoras entrevistadas mostraram-se receptivas à possibilidade de ter uma entidade acolhedora no conselho da escola. A questão em si é inovadora na medida em que as representações que possuem assento no Conselho Escolar dizem respeito aos segmentos: pais/mães/responsáveis, professoras, auxiliares de ensino, alunos (com mais de 12 anos) e um membro da gestão. A entidade, por analogia, ocuparia uma vaga na primeira condição, o que demandaria da representante do acolhimento maior sintonia pedagógica e administrativa com a escola e seus demais segmentos, ao mesmo tempo em que estaria mais atenta às reais condições de acato da entidade acolhedora às decisões do conselho escolar.

Diante da pergunta que indagava acerca de como é feita a articulação entre escola e abrigo no que tange à permanência escolar (questão 22), a maioria das diretoras de escolas (3 em 5) afirmou fazer das reuniões bimestrais, destinadas a comunicar o rendimento escolar dos alunos, espaços de encontro com as unidades de acolhimento.

Diante das informações obtidas, foi possível constatar que não há nas escolas uma agenda conjunta de trabalho além daquilo que é estabelecido pelo calendário escolar para todos os alunos, nem um protocolo para a recepção de um novo aluno acolhido que todas sigam com alguma uniformidade. Na medida em que os problemas vão surgindo, adequações entre as duas instituições são feitas para garantir a permanência escolar, o que faz com que os procedimentos em torno desta questão variem muito de escola para escola. A seguir transcrevemos alguns trechos obtidos nas entrevistas com as gestoras sobre esta relação:

No ato da matrícula também! Há uma conversa, a situação social, o que foi (o motivo do acolhimento). Se vier alguém da família aqui, (perguntamos) como a gente tem que agir [...]. (BX1) 
Assim, sempre que necessário. Sempre que a gente percebe que há necessidade de entrar em contato, a gente busca esse contato [...]. (GX2)

Eles (a unidade de acolhimento) vêm às reuniões bimestrais [...]. (DX1)

(Entrevistas à pesquisadora)

A preocupação em conhecer o aluno que está sendo matriculado na escola diz respeito a uma medida humanista, muitas vezes inviabilizada pelo desconhecimento por parte da própria profissional da unidade de acolhimento sobre as razões que levaram a criança à medida protetiva. É preciso considerar que muitas crianças são afastadas de suas famílias e levadas a uma instituição distante de sua comunidade, em que pese o ECA e as Otsaca, pois nem sempre há unidades próximas de seus locais de origem. Neste contexto, a criança precisa se inserir em uma nova escola situada em uma localidade desconhecida, condições que chegaram a ser identificadas pelo termo "pós-trauma" por uma professora no trabalho de campo para se referir às condições que alguns alunos acolhidos chegam à sala de aula.

O conhecimento prévio da história do aluno, defendido anteriormente pela gestora BX1, acena para uma relação mais promissora com os novos colegas, com a professora e com os conteúdos escolares, estando ou não a criança em uma condição "pós-traumática", conhecimento que possibilita propiciar, assim, uma permanência escolar proveitosa, com potencial de ser ampliada em possibilidades por uma agenda fixa de trabalhos interinstitucionais, respaldada pelo PPP.

Quanto a ver ou sentir a estigmatização em direção aos alunos acolhidos (questão 25), a questão foi elaborada com vistas a identificar o modo como isso se dava no ambiente escolar, prejudicando o processo de escolarização. No contexto da estigmatização, acreditamos que o aluno estigmatizado "ameaça, desorganiza, por representar o que foge do esperado, do eficiente, do padronizado pela sociedade" (SILVA; LIBÓRIO, 2005, p. 103), independentemente de ser uma criança com necessidades especiais, de origem suburbana, de grupo racial subalternizado ou institucionalizado por medida de proteção. Sobre esta questão, apenas duas diretoras disseram ter presenciado situações com esse conteúdo.

Nós fizemos a matrícula e fomos levar a aluna na sala; e, quando chegamos com a aluna na porta da sala para apresentar, a professora falou: - Minha sala está lotada! Ela falou na frente da aluna. Naquilo a menina já não quis entrar na sala. Daí a gente teve que fazer todo um trabalho, daí a gente conversou com a professora em particular e ela acabou pedindo desculpas pelo que fez e acabou até sendo ótima com a aluna durante o ano todo, dando bastante atenção. Talvez, se isso não tivesse acontecido, ela não teria dado a atenção adequada para a aluna [...]. (BX1) 
Há discriminação pelos próprios alunos. Eu vejo isso o tempo todo. A medida tomada é fazer sensibilização, fazer o aluno que discrimina se colocar no lugar do outro [...]. (DX1)

(Entrevistas à pesquisadora)

As palavras que marcaram seus depoimentos frente a esses eventos aversivos foram a respeito das medidas que tomam: conversa em particular e sensibilização dos ofensores. A questão é tratada no privado, sendo assim subtraída do seu conteúdo político. Em ambos os casos, vemos prevalecer um sentido individualizante para tratar do estigma, o que não promove um debate coletivo sobre as marcas e o significado de estigma que o ofensor imprime ao ofendido. Tão ou mais problemático que o reconhecimento do estigma por apenas duas diretoras é pensar que duas das gestoras que reclamaram de bullying não o relacionaram também a uma estigmatização. Quanto ao relacionamento da escola com o Conselho Tutelar (CT) no tocante às crianças acolhidas (questão 26), das 5 gestoras, 2 disseram que o relacionamento era ruim, 1 disse que o relacionamento era bom e 2 disseram que não precisaram se relacionar com ele.

Daquelas que se relacionaram com o CT, portanto, houve o predomínio das que o relacionam a um mau serviço, embora pouco utilizado para tratar questões ligadas a crianças acolhidas. Na escola Carmim, antes de nossa coleta de dados, ouvimos o seguinte relato: “[...] O Conselho Tutelar é fraco. Liga, liga e não faz nada [...]. O CT não atende às solicitações [...]. O CT está mais no papel [...]”. (FX1 - Entrevista à pesquisadora)

A gestora BX1 afirma que a relação "é péssima”. Disse precisar se deslocar para outra cidade, quando precisa resolver alguma questão, uma vez que o CT de Ceilândia não responde às suas demandas, inclusive na garantia de direitos em casos de alunos com necessidades especiais (ANE). A gestora CX1, por sua vez, disse ter o CT como uma presença positiva na resolução dos problemas da escola, inclusive no que se refere às crianças acolhidas, tendo precisado da intervenção dele somente uma vez. Disse que inclusive havia agendado uma palestra com o CT e ele prontamente colocou-se à disposição para contribuir.

De maneira geral, há uma insatisfação nas escolas atribuída ao fato de o CT ter uma grande demanda de queixas severas, o que acabaria por minimizar as solicitações de menor grau de gravidade, que resultariam desprezadas. Outro fato percebido na pesquisa é que há uma confusão entre a importância do papel do CT e o desempenho do conselheiro tutelar. Grosso modo, para aqueles que reclamaram da atuação do conselheiro tutelar, a imagem é que 
o serviço "existe apenas no papel”, uma vez que não obtêm o retorno na medida de suas solicitações.

No que tange a esta questão, Souza et al. (2003) constatam que a escola comparece ao CT para questões que não são exceções, para aquilo que é trivial:

Atrasos, problemas de relacionamento envolvendo alunos e problemas de aprendizagem não são casos que, em sua maioria, apresentem grande gravidade e para os quais a escola não possa construir mecanismos de enfrentamento. Aliás, estas são questões que a escola, pelo próprio objetivo educacional que a fundamenta, poderia se propor a trabalhar. (SOUZA, 2003, p. 78).

Ainda que muitas gestoras afirmem que algumas demandas possam ser resolvidas autonomamente pela escola, há de se pensar que ela se vê fragilizada frente a conflitos que reincidem, mesmo que não tão graves, não raro por temerem praticar violações na ânsia por resolução. A expectativa pela presença do CT, nesse sentido, acaba sendo frustrada pelo excesso de demandas recebidas pelo conselheiro tutelar e pela precariedade de condições dele na realização do seu trabalho, conforme nos foi explicado. No caso da escola Bege, soubemos da preocupação do conselheiro tutelar em matricular as crianças acolhidas na escola, tão logo a medida protetiva foi tomada. No entanto, a direção da escola reclama da inoperância do CT para a resolução de problemáticas outras que não sejam questões de evasão e de frequência escolar. Nas outras escolas em que sua presença foi requerida, o conselheiro não deu respostas satisfatórias sobre quaisquer solicitações.

As escolas gostariam de ser atendidas para além do art. 56 do ECA, que diz respeito a faltas injustificadas, à evasão e a maus-tratos de alunos detectados em ambiente escolar, demandas que vão além da matrícula. É um fenômeno a ser mais bem conhecido, até para que a escola não venha a reforçar mais ainda mecanismos de judicialização ${ }^{51}$ em seu âmbito.

Quanto à satisfação da escola em relação à unidade de acolhimento no trato das questões de indisciplina escolar dos alunos acolhidos (questão 27), as gestoras dividiram-se entre satisfeita (2), insatisfeita (2) e parcialmente satisfeita (1).

\footnotetext{
${ }^{51}$ Estela Sheinvar, a partir de extensa pesquisa, faz a importante consideração de que "O viés punitivo da escola tem encontrado aliança no Conselho Tutelar, cuja prática é vivida de forma ameaçadora. A característica singular do Conselho Tutelar é não ser do âmbito da justiça, mas a sua existência está diretamente vinculada a uma lei, o que tem contribuído para que use métodos da justiça. Não que a escola não seja punitiva, mas todos pensam que não cabe à escola julgar, condenar e punir, apesar da ênfase na sua função de controle dos alunos - o que acaba significando a adoção de práticas semelhantes às da justiça. Já ao Conselho Tutelar, proposto como um órgão de garantia de direitos, é associada uma demanda explícita por julgamento e punição. E ele não só corresponde a tais expectativas como, com sua prática, produz tal demanda".
} 
Três entre as cinco gestoras escolares mostraram-se insatisfeitas com a maneira como as unidades de acolhimento lidam com a indisciplina dos alunos, após a notificação desses eventos pela escola. As outras duas restantes mostraram-se parcialmente satisfeitas.

Os trechos das respostas obtidas por meio das entrevistas com as gestoras transcritos a seguir corroboram estes dados:

Não estamos satisfeitos. Às vezes a gente constrói aqui e eles desconstroem lá [...]. (BX1)

Elas teriam que ser mães cuidadoras e isto não está acontecendo... Elas estão lá para cuidar da segurança... Não estou satisfeita [...]. (DX1)

Não. O pessoal (as professoras) reclama muito [...]. (FY1)

Parcialmente. Tem umas mães sociais que são mais presentes [...]. (CX1)

A escola mesmo já conversou com ela (uma aluna) e viu que não é apropriado o que se faz por lá (na unidade de acolhimento) [...]. (GX1)

Parcialmente. Eles, no caso em que precisamos, jogavam a culpa na escola. Diziam que a gente não sabia lidar com ele (o aluno que foi transferido, já mencionado) [...]. (CX1)

(Entrevistas à pesquisadora)

Diante de tais relatos, constatamos que o acolhimento institucional, mais do que pensado como uma responsabilidade de uma entidade possuidora de uma função social prevista em legislação e exercida por profissionais específicos, é visto pelas gestoras e professoras quase exclusivamente como um serviço executado pelas cuidadoras sociais. As cuidadoras são vinculadas às figuras de mães, o que gera expectativas equivocadas sobre elas. As cuidadoras-educadoras têm, segundo as Otsaca, o papel de cuidar das crianças e adolescentes e zelar pela rotina da casa. Assim, por mais que a afetividade seja um componente da sua atividade diária, ela não se pode confundir com a tarefa maternal, pois não está na entidade como adotante, mas como profissional de cuidados. Nesse sentido, temos que:

A presença do educador/cuidador residente visa a proporcionar: estabelecimento de uma relação estável no ambiente institucional, uma vez que o educador/cuidador residente ocupa um lugar de referência afetiva constante, facilitando o acompanhamento da vida diária/comunitária das crianças/adolescentes (reuniões escolares, festas de colegas, etc.), diferentemente do que ocorre no Abrigo Institucional, onde há maior rotatividade diária de educadores/cuidadores. (CONANDA/CNAS, 2009, p. 53).

Trata-se, então, de uma profissional - em geral mulheres - que deve ser assistida pelos técnicos e direção da unidade de acolhimento, a fim de que execute seu trabalho em consonância, pelo menos, com o ECA, as Otsaca e o PPP do abrigo. A culpabilização 
individual por erros ou omissões por elas cometidos esvanece a responsabilidade da entidade de acolhimento como um todo. Por mais que as assistentes sociais e psicólogas das unidades de acolhimento sejam conhecidas pela direção da escola, e por vezes até as suas gestoras, a entidade tem na cuidadora-educadora a sua figura mais expoente dentro do espaço escolar. É dela que são cobrados em primeira instância todos os cuidados com as tarefas e com a disciplina que as crianças devem ter, mesmo que não seja de todo a responsável por toda a rotina da entidade.

Assim, a cuidadora-educadora passa a ser a depositária de parte considerável da insatisfação com a entidade, posto que aparece para parte das professoras (não para as gestoras da escola) como a sua "cara". Há professoras que se ressentem do excesso de profissionais dentro da unidade de acolhimento, pois dizem que, pelo fato de deverem obediência a todo mundo, as crianças e adolescentes acabam não obedecendo a ninguém. É a figura da cuidadora-educadora que acaba sendo a receptora de toda essa crítica. O coletivo da entidade não é visto nem cobrado em sua inteireza pelas professoras/gestoras. É importante considerar que nas Otsaca não há uma menção sobre o que entende por educação, tampouco as relações que o acolhimento guarda com espaços educativos. Assim, tanto a educação formal escolarizada quanto as relações internas na instituição acolhedora ficam prejudicadas, fato que ocasiona reflexos de uma em outra.

Em nosso material de análise, tivemos acesso a três situações que indispunham as cuidadoras com os alunos acolhidos, questões que passavam por privação de conforto para a criança dormir, por atritos que levaram o aluno a acidentar-se na tentativa de se livrar de uma situação conflituosa, além de situações como atrasos dessas profissionais no horário da saída do turno escolar, quando deveriam buscar as crianças. A pesquisa da Fiocruz (2013) situa que, no Centro-Oeste, cada criança ou adolescente permanece na unidade de acolhimento por cerca de 21,5 meses, o que significa um tempo considerável, particularmente para crianças na primeira etapa do ensino fundamental, cujas idades variam entre 6 e 10 anos. Trata-se de um tempo de construir hábitos de estudo, de acessar os primeiros conteúdos da literatura, de aprender a conviver, respeitando a diversidade e a todos em momentos de conflito, situações em que a severidade e o carinho devem estar pactuados como pressupostos educativos entre todos os agentes que cuidam dessas crianças para que elas acessem seus direitos educacionais com maior desempenho. Afinal, o acolhimento não pode ser um serviço que forneça e proporcione teto, alimentação, atividades recreativas e culturais, saúde e escolarização sem 
um fio condutor educativo, firme em seus propósitos, que faça cada criança percebê-lo nesse seu intento. Neste sentido, partilhamos do entendimento de Makarenko (2010):

$\mathrm{Na}$ maioria dos casos, as pessoas não sabem conciliar o carinho e a severidade, coisa absolutamente necessária na educação. Frequentemente vemos que as pessoas entendem esses problemas, porém pensam: é justo que a severidade tenha um limite, que o carinho se adapte a certas normas, contudo, isto será necessário quando a criança tiver seis ou sete anos; até esta idade, poderemos passar sem normas. [...] Eu não entendo por severidade nenhuma espécie de raiva nem de gritos histéricos. A severidade só é boa quando não tem nenhum indício de histeria. $\mathrm{Na}$ minha prática, aprendi a ser severo utilizando um tom muito carinhoso. $\mathrm{Eu}$ podia, com absoluta amabilidade, cordialidade e tranquilidade, expressar palavras que deixariam meus comunheiros pálidos. A severidade não supõe que obrigatoriamente se tenha de gritar ou grunhir. (MAKARENKO, 2010, p. 90/91).

Acreditamos, portanto, que o trabalho realizado entre escola e unidade de acolhimento só poderá atingir satisfação mínima para ambas quando houver uma agenda comum que situe bem o sujeito de direitos de que está investida cada uma, a fim de vislumbrar uma permanência escolar mais promissora. A questão 36 do formulário utilizado nas entrevistas com as gestoras (Anexo C) referiu-se aos problemas que geram indisciplina por parte dos alunos acolhidos, sendo que as respostas mais recorrentes foram estigmatização dos alunos (duas gestoras) e não adaptação à rotina da escola (duas gestoras).

Estas impressões identificam que a indisciplina parte de questões que fogem a uma esfera individual. A não adaptação à rotina da escola e a estigmatização de alunos em seu interior, seja por parte de alunos para com outros alunos ou de trabalhadores da educação para com alunos, indica que a pedagogia a ser incorporada pelas escolas não pode ser idealista. Necessita estar sintonizada com os interesses populares, buscando métodos eficazes para grupos muito distintos de crianças ou adolescentes, como apontado por Saviani (2008):

Tais métodos se situarão para além dos métodos tradicionais e novos, superando por incorporação as contribuições de uns e de outros. Portanto, serão métodos que estimularão a atividade e iniciativa dos alunos sem abrir mão, porém, da iniciativa do professor; favorecerão o diálogo dos alunos entre si e com o professor, mas sem deixar de valorizar o diálogo com a cultura acumulada historicamente [...]. (SAVIANI, 2008, p. 72).

Entende-se, a partir disso, que a escola deve usar de seus instrumentais para acolher tais alunos em suas características próprias, respeitando suas narrativas, sem subestimar suas capacidades, e assim fazer as mediações possíveis na ordem sócio-histórica que está dada, para que atinja os conteúdos universalmente acumulados, mesmo que isso seja difícil e demorado. A construção de novas rotinas para os alunos que ainda não se adaptaram a elas 
faz parte de um esforço conjunto da escola para com o aluno e não de sua vontade solitária. A convocação dos elos do SGD é fundamental para tanto.

Materializar as políticas de inclusão, por vezes, requer sair da esfera da unidade de ensino, ainda que isso seja contraditório com o papel da escola, que tem por função ensinar e esperar a aprendizagem. O que se quer reforçar com essa busca é que tudo aquilo que venha a afastar a criança da escola deve ser visto como uma violação de direitos e problematizado nesse sentido. Há de se pensar também que a escola é um espaço de convivência comunitária, devendo estar apta a construir vínculos e não a inviabilizá-los. Não pode, portanto, fazer do silêncio cômodo um meio de fortalecer situações estigmatizadoras. Se houver mediações, deverão ocorrer no sentido de escolarizar as crianças, em que pesem suas dificuldades com os afazeres da escola e suas narrativas de discriminação, usurpação e posterior acolhimento.

As questões 37, 38, 39 e 40 diziam respeito, respectivamente, à repercussão das advertências orais e escritas para os trabalhos de classe, repercussão das advertências orais e escritas para o próprio aluno, repercussão das suspensões para os trabalhos de classe e repercussão das suspensões para o próprio aluno. Foram analisadas em bloco, dada a articulação entre as quatro, e referem-se somente aos alunos acolhidos institucionalmente. Assim, os resultados das advertências orais e escritas dividiram opiniões, tendo em vista que duas diretoras as consideraram positivas para a classe escolar e duas as consideraram parcialmente positivas. Apenas uma gestora a considerou uma medida negativa. Do ponto de vista da repercussão dessas advertências para os alunos acolhidos, duas gestoras consideraram que elas repercutiam mal, duas consideraram bem e uma considerou que a repercussão era parcialmente boa. Com relação às suspensões, apenas uma gestora a encarou como uma medida positiva para a classe. Duas outras a interpretaram como algo negativo e duas jamais a teriam aplicado com crianças acolhidas, não podendo avaliar os seus resultados. Em se tratando da repercussão da suspensão na vida escolar dos alunos, uma gestora a considerou parcialmente positiva, duas disseram que não era positiva e duas disseram ser impossível afirmar algo, tendo em vista que não a aplicaram.

Faz-se importante detalhar que a advertência oral (questões 37 e 38) se resume a uma conversa em particular com os alunos junto ao professor e à direção. Esta é a modalidade mais utilizada nas escolas para com os alunos, acolhidos ou não. A advertência escrita, além da conversa, demanda um documento com assinatura da direção, que deverá ser encaminhado para os pais, mães ou responsáveis. Na opinião das direções, ambas as advertências podem apaziguar 
a sala de aula, embora haja divisão entre elas sobre sua repercussão para os alunos advertidos. Podemos perceber, nos dois tipos de advertência, que a questão da disciplina é individualizada, não sendo tomada como um problema de toda a classe em que o aluno está matriculado. Nas respostas obtidas não houve comentários a respeito das três primeiras questões.

No caso das suspensões (questões 39 e 40), as opiniões foram mais divididas. A escola Carmim, apesar de já ter efetuado uma transferência acordada de um aluno acolhido em outro ano letivo, fixou-se no tempo presente da entrevista para dizer que não havia casos de suspensão, abstendo-se de responder sobre o efeito da pergunta. A escola Grená não havia praticado a suspensão com a sua única aluna acolhida. Disse que "lugar de criança é na escola" ao destacar no formulário (Anexo C) que não havia casos de suspensão. Duas das escolas que já haviam ministrado a suspensão (Bege e Dourado) não acreditavam que esta modalidade fosse positiva para a classe, embora necessária para os alunos. A gestora da escola Dourado afirmou que "nenhuma das vezes" a criança volta melhor da suspensão. Somente a escola Ferrugem acreditou que as suspensões se revertiam positivamente para a classe.

Ainda que as suspensões não sejam um hábito nas escolas visitadas, não se repetindo com uma periodicidade fixa, elas se configuram como um momento de tensão na escola. No caso de crianças que já vivenciam um alijamento familiar, a suspensão torna-se mais um desses episódios de apartação. Por mais que a medida acarrete tarefas domiciliares, há perda de aula, de convivência comunitária, subtração de vivências importantes da infância, elementos que guardam semelhanças com um olhar menorista, principalmente em se tratando de alunos sob medida protetiva. Isso porque "os menores" de ontem tinham no abrigo um lugar de confinamento, de onde sequer saíam para estudar, uma vez que os estudos eram ministrados dentro do estabelecimento, em uma escola interna. A lógica individualizante torna-se mais acentuada na adoção desse tipo de punição. E o que a escola ganha com isso? A paz dos cemitérios, a paz sem vida, sem diversidade, sem contraditório.

Com relação aos motivos que levam à evasão dos alunos acolhidos ou a uma permanência pouco proveitosa (questão 42), o despreparo da escola (4 gestoras) e a falta de acompanhamento de seus responsáveis foram as opções mais aventadas pelas gestoras (4 gestoras). Além da dificuldade dos alunos frente aos conteúdos apresentados (3 gestoras) pela escola.

Assim, as próprias gestoras confirmam o despreparo da escola para lidar com os alunos em acolhimento institucional, apesar de não terem comentado suas respostas. $\mathrm{O}$ fato de o acesso à escola estar garantido às crianças e adolescentes abrigados não diz respeito às condições que a escola oferece para que a permanência escolar se efetive com aprendizagem 
de qualidade social. A falta de acompanhamento de pais ou responsáveis, outra de maior incidência, recebeu o seguinte comentário: “[...] é o caso dos meninos (acolhidos). Como não têm um responsável para acompanhá-los, eles se sentem tipo 'eu posso fazer tudo o que eu quero, que não vou ser punido' [...]”. (CX1 - Entrevista à pesquisadora).

O que está em questão é a capacidade de a escola cumprir com todo o arsenal de direitos que estão previstos para grupos sociais que sempre foram estranhos a ela frente à realidade de insidiosos (e desidiosos) ataques colocados por políticas neoliberais para o seu melhor funcionamento. Citamos o documento Ensino Fundamental de nove anos: passo a passo do processo de implantação (BRASIL, 2009), que dispõe que os sistemas de ensino e as escolas, dentro dos limites de sua autonomia, podem proceder a diferentes adequações para atenderem a determinados fins e objetivos do processo educacional. Dentre elas, e em conformidade com a Resolução do Conselho Nacional de Educação (CNE) e da Câmara de Educação Básica (CEB) no 7/2007, o documento elenca:

a) promoção da autoestima dos alunos no período inicial de sua escolarização;

b) o respeito às diferenças e às diversidades no contexto do sistema nacional de educação, presentes em um país tão diversificado e complexo como o Brasil;

c) a não aplicação de qualquer medida que possa ser interpretada como retrocesso, o que poderia contribuir para o indesejável fracasso escolar;

d) os gestores devem ter sempre em mente regras de bom senso e de razoabilidade, bem como tratamento diferenciado sempre que a aprendizagem do aluno o exigir. (BRASIL, 2009, p. 13).

Nesse contexto, a plasticidade que está colocada para uma escola que se vê engessada por obrigações incessantes, que tem docentes com rotinas pesadas de trabalho junto a turmas numerosas, é muito pequena. No caso em tela, a chamada "razoabilidade" e o "bom senso" para tratar da diversidade não ocorrem sem um conhecimento minimamente satisfatório do que venha a ser a realidade dos alunos em acolhimento e as vulnerabilidades que uma sociedade extremamente desigual como a brasileira a eles impõe. Não é possível ignorar que as diretorias das escolas pesquisadas acabaram por assumir, por meio de suas respostas, uma das impotências mais dilacerantes da escola: o despreparo para a diversidade, fato que deve ser visto como uma falta e uma responsabilidade a ser compartilhada por todas as esferas do Estado para garantir efetivamente o caráter universalizante da educação.

Sobre a disponibilidade, na escola, de publicações e outros materiais informativos no tocante à aprendizagem e às particularidades de alunos em acolhimento institucional (questão 43), todas as gestoras disseram não conhecer quaisquer materiais a esse respeito. Nem livros, 
apostilas, CD-ROMs ou quaisquer outros, nem mesmo aqueles publicados pela Secadi-MEC foram mencionados, o que acaba por se tornar uma demanda escolar bastante compatível com uma proposta de permanência qualificada dos alunos sob a medida de proteção abordada. Espera-se que, quanto mais amplo o entendimento da realidade dessas crianças, maior a possibilidade de acertos nas estratégias pedagógicas.

A rede de proteção, promoção e defesa voltada para a infância e a adolescência é instituída pelo conjunto de planos, sistemas e instituições que constituem o Sistema de Garantia de Direitos (SGD). É inegável que ela é fundamental para a efetivação dos direitos das crianças e adolescentes acolhidos institucionalmente, por exemplo a permanência escolar. A falta de diálogo ou efetivação de ações conjuntas entre as esferas e instituições, muitas vezes observadas nas pesquisas junto às gestoras, apresenta-se como um óbice no processo de escolarização desses alunos. Com relação a esta questão, cabe considerar que:

É esta mesma "rede" que sofre, além do distanciamento e ausência do diálogo interinstitucional e intersetorial, da carência de infraestrutura, de condições e qualidade de atendimento, de pessoal capacitado (na ótica e na concepção dos direitos). Não são poucas as situações em que crianças e os adolescentes são tratados como problema, reeditando a velha máxima da periculosidade, em vez de serem considerados sujeitos de direitos, conforme a doutrina da proteção integral pressuposta no ECA e em todas as normativas que dele derivaram [...]. (CFESS Manifesta, 2010, p. 2).

Neste sentido questionamos às gestoras se havia atuação das escolas com a rede de proteção para garantir a permanência escolar do aluno acolhido (questão 45). Mediante tal indagação, três das cinco gestoras das escolas entrevistadas disseram buscar serviços da rede de proteção fora da SEDF; uma escola disse buscar o serviço na esfera da SEDF e uma disse não procurar a rede.

À primeira vista esses dados parecem bastante satisfatórios, no entanto pudemos verificar que, embora essas escolas procurassem ultrapassar os seus muros em busca de auxílio para suas demandas junto aos alunos acolhidos, a instituição a que mais recorre para esse intento é o Conselho Tutelar. Tal constatação ocorreu em função dos relatos das três gestoras que disseram extrapolar a esfera da SEDF quando indagadas qual o órgão ou instituição que buscavam para trabalhar em rede. Uma interpretação que aponta que a visão de rede precisa ser ampliada, sob o risco de inviabilizar uma visão mais geral da problemática em que os alunos acolhidos estão inseridos, tendo em vista o papel pouco abrangente do conselheiro tutelar dentro do que está determinado pelo EC. Vale mencionar que ao mesmo tempo percebemos a não menção das diretoras à atuação do Conselho Escolar em situações menos corriqueiras (como os 
reparos na estrutura, a decisão sobre um gasto ou a compra de materiais de consumo, etc.) e de maior cunho político-pedagógico, como aquelas relacionadas à permanência de estudantes acolhidos. Nesse sentido, o Conselho Escolar figura como uma potencialidade não explorada, empobrecendo-se como organismo de debate e decisão, inclusive pedagógica.

\subsection{As entrevistas com coordenadoras}

\subsubsection{Equipe técnica da unidade de acolhimento}

Como expusemos anteriormente, a entrevista com as coordenadoras (gestoras) das duas unidades de acolhimento partiu de um instrumental que envolveu perguntas objetivas e subjetivas. Em vários momentos as respostas extrapolaram o referido instrumental, o que permitiu enxergar novas realidades ainda não atinadas por nós. Fomos recebidos na UA1 pela coordenadora da entidade (PUA1), cuja formação é em Pedagogia. Na UA2, quem nos recebeu foi a assistente social da unidade (PUA2). Ambas as unidades pertencem à modalidade casa-lar, fechadas em um condomínio. As casas-lares são definidas nas Otsaca como um:

Acolhimento Institucional oferecido em unidades residenciais, nas quais pelo menos uma pessoa ou casal trabalha como educador/cuidador residente - em uma casa que não é a sua - prestando cuidados a um grupo de crianças e/ou adolescentes. (CONANDA/CNAS, p. 106).

Apenas a UA1 é conveniada com a Sedest, embora as Otsaca sirvam como parâmetro para o funcionamento também daquelas entidades não conveniadas. As duas entidades assistenciais recebem alunos das cinco escolas que fizeram parte de nosso campo na área de educação. As duas unidades de acolhimento tinham todas as crianças matriculadas e frequentando a escola, exceto aquelas que tiveram suas medidas de proteção executadas quase no encerramento do ano letivo. Cada unidade forma a sua equipe para tratar da escolarização das crianças acolhidas. Embora a educadora-cuidadora seja a responsável direta pela criança, há rearranjos para as visitas escolares, nos quais ela pode estar ou não incluída. Na UA1 houve a contratação de uma pedagoga, o que, segundo a coordenadora, deu uma qualidade maior ao acompanhamento escolar realizado junto aos estudantes que nela residem.

Geralmente é a educadora social orientada pela pedagoga. A pedagoga, em muitos casos, vai também, dependendo de cada caso. Tem casos específicos que é importante ela ir com a cuidadora. Reuniões para saber de problemas, a cuidadora vai junto com a pedagoga para dar explicações [...] Há muita cobrança 
da instituição. A escola às vezes acha que a criança tem aquele comportamento devido a problemas dentro da instituição. [...] é preciso ter conhecimento técnico para estar explicando e até para ter a parceria da escola [...]. (PUA1)

É a equipe técnica: assistente social, coordenadora ou a psicóloga. Vai a que está disponível. Na ausência da equipe técnica, vai a cuidadora. [...]. (PUA2)

(Entrevistas à pesquisadora)

Nas Otsaca está previsto que, para o exercício da função de educador-cuidador, o profissional:

Deve ter capacitação adequada para desempenhar seu papel com autonomia e ser reconhecido como figura de autoridade para a criança e o adolescente e, como tal, não ser desautorizado pelos outros profissionais do serviço (técnicos, coordenadores), sobretudo na presença da criança e do adolescente. Além disso, devem contar com apoio e orientação permanente por parte da equipe técnica do serviço. (OT, 2009, p. 48).

De alguma forma, busca-se suprimir, com rearranjos de profissionais, as lacunas na formação das educadoras-cuidadoras no trato de questões escolares, por elas envolverem muitos alunos com trajetórias acadêmicas bastante complexas, demandando conhecimentos específicos para os problemas que se apresentam. As capacitações, por mais que existam, parecem ser insuficientes para as demandas colocadas para elas. Pedagogas contratadas ou estagiárias acabam por cumprir um papel protagonista quando o assunto é acompanhamento educacional.

No cotidiano das unidades de acolhimento, a ideia de parceria é muito recorrente. Falar em serviços de acolhimento é quase sempre recorrer a esse termo de matiz neoliberal. Então, se a presença de outros profissionais se faz necessária, bem como novos insumos, as parcerias são buscadas de maneira naturalizada. Não assistimos a um debate sobre a indisponibilidade de recursos, mas a uma necessidade de manter as parcerias, fosse a da psicopedagoga (UA1), fosse a de estagiárias do curso de Pedagogia (UA2).

Há particularidades em cada entidade quanto à profissional que faz o acompanhamento escolar do aluno dentro da unidade de acolhimento. Algumas contratam pedagogas, outras não. Nas Otsaca não está prevista a presença de profissional de Pedagogia como membro da equipe técnica. “[...] A pedagoga não olha caderno por caderno. Sempre orienta a cuidadora [...]. A cuidadora olha as tarefas e a pedagoga faz a supervisão [...]”. (PUA1 - Entrevista à pesquisadora).

Constata-se também uma alta consideração nas falas das duas técnicas ao trabalho da pedagoga dentro da entidade, tendo em vista que ela direciona os trabalhos voltados para a resolução de problemas frente à escolarização das crianças, "não os deixando sem respostas" (PUA1). Na compreensão da coordenadora da UA1, a pedagoga, além do papel de detectar 
problemas na aprendizagem das crianças, na relação delas com a escola, e de identificar possíveis acometimentos em sua saúde, também "encontra mecanismos fora da instituição, parceiros que possam auxiliar" (UA1), como uma psicopedagoga, por exemplo. E reitera: "[...] A pedagoga tem um olhar diferente, ela sabe detectar! Olhar para a criança e perguntar: - Por que você não gosta de ir para a aula? - Por que não interage com os coleguinhas? [...]” (PUA - Entrevista à pesquisadora).

A assistente social da UA2 confirma a impressão anterior, mesmo não tendo uma pedagoga em seu quadro. Em sua unidade assistencial, aquelas que recebem os resultados bimestrais das crianças, bem como comparecem a eventos pedagógicos na escola, são as técnicas em Psicologia, Assistência Social ou a coordenadora. Costuma cumprir a atividade aquela que esteja mais disponível.

No entanto, a unidade 2 conta com o trabalho de estagiárias em Pedagogia para auxiliar em tarefas da escola. A coordenadora, em entrevista, disse que seria importante ter um pedagogo: “Tem que ter!" (PUA2). Mencionou ainda que seu sonho era ter uma "Pedagogia da Presença" 52 na unidade, acrescida do trabalho de reintegração das crianças ao lar, pois a primeira construiria neles uma motivação, e os alunos aprenderiam a respeitar as pessoas e a levar esse conhecimento para fora.

A expectativa das escolas com a Psicologia talvez seja compatível, em dimensão, com a das duas unidades de acolhimento frente à figura da pedagoga, tendo em vista que as demandas da escolarização são intensas e ocupam as profissionais de outras áreas para executá-las, uma vez que as limitações das cuidadoras-educadoras para os exercícios de atividades relativas à escola são consideradas limitadas. "A cuidadora ia nas reuniões, não tinha uma bagagem, não tinha o entendimento de como resolver o problema [...]”. (PUA1 - Entrevista à pesquisadora).

Para se ter ideia, todas as cuidadoras da UA2 têm somente o ensino fundamental, o que, sob vários aspectos, torna a compreensão da dinâmica escolar limitada, o que se agrava quando se pensa na interseção da escola com o acolhimento.

Nenhum profissional da Educação, com graduação em Pedagogia ou outra licenciatura qualquer, está previsto na formação das equipes técnicas dos serviços de acolhimento de

\footnotetext{
${ }^{52}$ A Pedagogia da Presença vem sendo divulgada pelo professor Antonio Carlos Gomes da Costa (2002). Nela o estudante recebe estímulo para exercer protagonismo, a fim de tornar-se líder; e é direcionado à educação profissional e à cultura da trabalhabilidade. Há um estímulo ao empreendedorismo, focando a formação do jovem em habilidades relacionadas à gestão. Características que colocam a referida Pedagogia dentro de uma consonância com a ordem.
} 
crianças e adolescentes. Sendo assim, as unidades que têm esses profissionais fizeram-no independentemente das Otsaca, por outra compreensão da extensão do serviço. Sobre aquilo que a unidade proporciona que possa contribuir para a escolarização das crianças (questão 3), podemos observar alguns recursos utilizados no Gráfico 10.

\section{Gráfico 10}

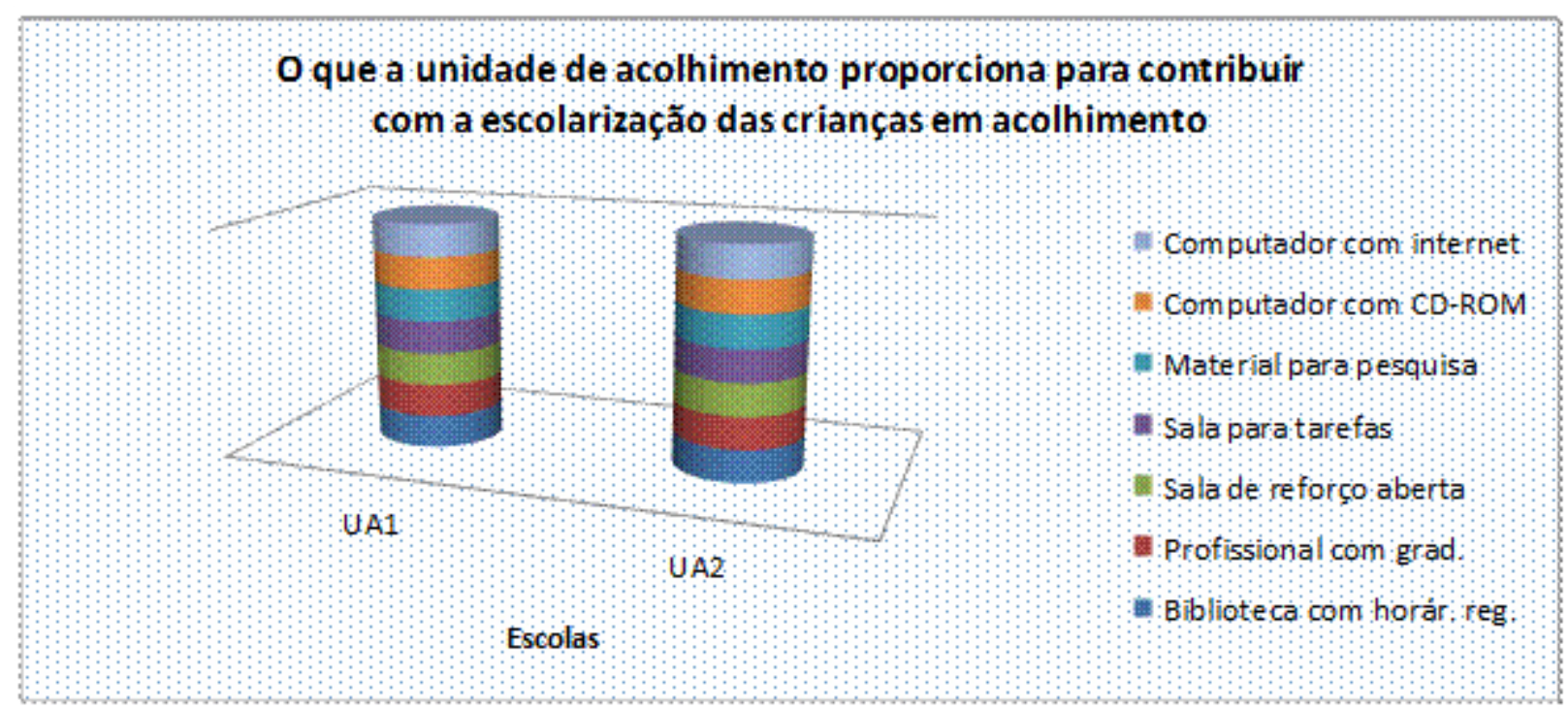

Elaboração própria conforme dados da entrevista. Distrito Federal, 2013.

Entidades assim contam com espaços para executar os deveres de casa ministrados pela escola, possuindo também um acervo mínimo para as pesquisas dos acolhidos, crianças ou adolescentes. Embora dividam espaços como a biblioteca para tarefas como a execução do dever de casa, há condições físicas de as crianças darem continuidade aos trabalhos iniciados em sala de aula, havendo possibilidade também de os realizarem em seus próprios quartos.

Ao discorrerem sobre as atividades realizadas pela unidade de acolhimento que podem contribuir para uma boa escolarização das crianças, percebemos muita expectativa nos projetos realizados com a ajuda do voluntariado. Talvez isso ocorra porque as entidades não estejam satisfeitas com as atividades feitas no contraturno, em projetos de atividades socioeducativas - constitutivos da Proteção Social Básica (PSB), que está inserida na Política de Assistência Social -, como é o caso da UA1. O chamado "socioeducativo" oferece atividades recreativas, culturais e condições para realizar o dever de casa, embora não o faça a contento. Daí o investimento no papel do voluntariado para realizar as tarefas escolares dentro da própria unidade de acolhimento. 
começam, e acaba que não terminam. Já teve vários. Hoje a gente está com uns que iniciaram recentemente. Estão com frequência, mas a gente não sabe se vão dar continuidade [...]. (PUA1 - Entrevista à pesquisadora).

Vemos repetir o mesmo pensamento na UA2, ao esperar que duas estudantes em Pedagogia se juntem a outras tantas, voluntárias, para implantar um projeto "para dar mais atenção às crianças" (PUA2). O depósito de esperanças no voluntariado torna ainda mais frágeis os serviços prestados por entidades privadas. Ou seja, além de um quadro de baixos salários praticados pelas unidades de acolhimento a suas profissionais, vê-se ainda o ingresso do voluntário em uma situação que aponta para a precarização do trabalho, que se torna menos profissional, falho técnica e politicamente, descontínuo, consolidando um viés missionário vinculado à boa vontade. Importa dizer que, na medida em que as escolas do Distrito Federal venham a oferecer o turno integral, uma nova realidade se configurará em pesquisa, uma vez que os projetos socioeducativos de caráter privado poderão jogar menos papel no contraturno, o que merecerá mais atenção em investigações futuras.

No tocante ao que pode prejudicar a escolarização das crianças no cotidiano da unidade de acolhimento, o passado vivido pelas crianças aparece como grande fator prejudicial à escolarização. "A criança do $1^{\circ}$ ao $5^{\circ}$ ano fala muito na mãe. E a professora pergunta: - Onde está sua família? Papai, mamãe?” (PUA2). A assistente social acredita que o grau de exposição que as crianças sofrem ao reportarem suas memórias aos colegas de classe acaba se voltando contra elas mesmas, uma vez que terminam por ser alvo de preconceitos e chacotas. PUA1 reitera o pensamento: "As crianças que estão aqui não vieram por vir. Tem uma história séria por trás [...], a criança traz consigo esses traumas. Se a gente não se ativer ao psicológico, a aprendizagem fica prejudicada".

Também nessas situações a ação voluntária vem em socorro, de maneira individualizante: “Os voluntários fazem o atendimento psicológico. Os atendimentos são somente para quem viveu abandono, abuso sexual, devolução na adoção" (PUA1). Se a situação de instabilidade emocional, traumas e medos vivenciados por essas crianças e também pelos adolescentes atravancam ou podem dificultar-lhes o crescimento em termos escolares, nada é pensado em termos coletivos. Ainda não se aposta também em medidas que envolvam a escola e a unidade de acolhimento em um projeto comum com vistas a garantir uma permanência escolar que não reavive situações perturbadoras.

Buscamos saber se havia condições de as crianças estudarem privadamente, em seus quartos, sem necessariamente precisarem se retirar de casa. Em ambas as unidades, isso se 
fazia possível. A respeito da formação das cuidadoras-educadoras, a UA1 tinha $80 \%$ das funcionárias com ensino fundamental, $20 \%$ com ensino médio; na UA2, $100 \%$ com ensino fundamental; o que é um complicador, como já foi mencionado, inclusive nas relações dessas profissionais com a escola, que pede a mediação de profissionais de nível superior nas reuniões escolares, não raras vezes.

A maior dificuldade sentida no processo de escolarização das crianças em acolhimento diz respeito à leitura para crianças que estão fora da faixa etária prevista para o ano que cursam. "Tem criança aqui que era de rua, nunca viu a letra". (UA1 - Entrevista à pesquisadora). No mesmo raciocínio, UA2 completa: “[...] Eu estou com um menino de nove anos [...], nunca foi à escola. Estava matriculado, mas nunca foi à escola. Um menino de nove anos no primeiro ano?”. (UA2 - Entrevista à pesquisadora).

Do ponto de vista do atendimento na escola pública do Distrito Federal, há Diretrizes Pedagógicas que contemplam o ingresso de crianças dentro ou fora da faixa etária no Bloco Inicial de Alfabetização ${ }^{53}$ (BIA), compreendido como os três primeiros anos do ensino fundamental, não havendo condições de se reprovar as crianças nessa primeira etapa de escolarização. “O Distrito Federal adotou a progressão continuada no Bloco, defendendo a não retenção dos alunos nos anos iniciais da alfabetização, na direção do que é defendido e preconizado pelo Ministério da Educação”. (DISTRITO FEDERAL, 2012, p. 10).

Assim, se uma criança é matriculada no $2^{\circ}$ ou $3^{\circ}$ ano de escolaridade sem conhecer as vogais e consoantes, ela deverá receber uma atenção específica de acordo com o que sabe e o que necessita aprender. $\mathrm{O}$ curso do Pnaic vem sendo ministrado às alfabetizadoras na rede do DF para se trabalhar com a diversidade de alunos que acorrem às escolas, respeitando-lhes os níveis de compreensão da leitura e da escrita, cabendo à professora e à escola construírem em classe estratégias de aprendizagem compatíveis com os níveis de cada aluno.

Dessa forma, a partilha de conhecimentos sobre o BIA $^{54}$ com as unidades de acolhimento é fundamental para que se fortaleça a ideia de que a escola tem o dever de estar

\footnotetext{
${ }^{53}$ A partir da promulgação da Lei $\mathrm{n}^{\circ} 3.483$, em 25 de novembro de 2004, o Distrito Federal estabeleceu a implantação do Ensino Fundamental de 9 Anos na Rede Pública de Ensino do Distrito Federal. No tocante aos anos iniciais, construiu-se a proposta pedagógica do Bloco Inicial de Alfabetização (BIA), que atendia à Lei Federal ${ }^{\circ}$ 11.274 , de 6 de fevereiro de 2006, em seu art. $5^{\circ}$. Buscava ela também a reorganização do tempo e do espaço escolar, com vistas a contemplar os objetivos do PNE 2001 (no que diz respeito à redução das desigualdades sociais e regionais e a uma permanência escolar com sucesso) e um processo de educação de qualidade. (DISTRITO FEDERAL, 2012).

${ }^{54}$ Mesmo não abraçando os referenciais teóricos em que o documento do BIA se pauta, acreditamos que é importante que eles sejam partilhados com as unidades de acolhimento, a fim de que compreenda os caminhos que a docente/escola percorre para concretizar a aprendizagem nessa etapa de escolarização.
} 
aberta ao aluno no estágio de aprendizagem em que ele estiver, seja qual for a sua idade. Para tanto, existem as atividades de reagrupamento e os projetos interventivos, que permitem que as crianças sejam respeitadas conforme os seus níveis de compreensão, seja no que se refere à Psicogênese da Língua Escrita, nas dificuldades de problematização e pensamento lógico matemático; na produção de textos, e mesmo naquilo que diz respeito à interação e processos ligados à autoestima, bastante afetos às necessidades das crianças em acolhimento institucional.

Do ponto de vista de aquisições individuais que ainda faltariam às crianças para um melhor desempenho, tivemos como resposta a motivação e rotina de estudos. Quanto à motivação, há a compreensão equivocada de que todas as crianças que não possuem a realidade das acolhidas têm motivação para estudar. "Você vê que toda criança gosta de brincar de escolinha, de ler um livrinho. Eles (os acolhidos) só fazem o que o professor manda. E eles não têm motivação para o dever de casa". (PUA2). Ao falar de rotina para os estudos, PUA1 tem o entendimento de que ela é construída no cotidiano, mediante condições para isso. Admite que a jornada doméstica e de cuidados (levar ao hospital, cuidar dos enfermos, etc.) das cuidadoras é intensa, o que dificulta a formação de uma rotina de estudos junto aos acolhidos: "É tanta coisa, que a educação fica em segundo plano. Não olha a agenda, não olha o caderno. Falta de tempo. Não é porque ela não quer”.

No mesmo caminho de uma construção histórica, que varia de pessoa para pessoa, entendemos a motivação. Para o cientista russo Leontiev, os motivos para qualquer atividade humana erguem-se na vida social. Aquilo que os impulsiona está dentro das relações sociais de cada indivíduo. De tal maneira que acena para a:

Compreensão da motivação (o aparecimento dos motivos) é a natureza social do psiquismo. Isso significa que os motivos para aprender, bem como todo e qualquer motivo, não são dados invariáveis da vida individual, mas dependem em grande medida da qualidade das relações sociais e dos processos educativos vividos ao largo do desenvolvimento. Por isso, estar motivado para aprender é, antes de tudo, estar na escola. Além dessa condição, o conhecimento deve ser o objeto que impulsiona a atividade do aprendiz. (MESQUITA, 2010, p. 6).

Tudo isso aponta para uma lenta caminhada, que vai se construindo aos poucos, no início da escolarização, até que a motivação seja uma realidade ao final dela. Nesse sentido, a motivação requer tempo e condições para desenvolver-se, não existirá sem o acúmulo de vivências em seu benefício. Entendemos que uma rotina de atividades bem consolidada nas unidades de acolhimento pode contribuir para isso. 
Muitas lacunas apareceram com relação às reclamações e/ou elogios que as crianças profeririam quando o tema era a escola. "Por incrível que pareça, eles não reclamam. Nunca chegaram reclamando. Nem reclamam, nem elogiam". (PUA2). A discriminação e o tratamento diferenciado frente a conflitos que ocorrem na escola são as maiores reclamações que as crianças da UAC1 costumavam fazer. Quanto aos elogios, PUA1 afirmou: "sinceramente, eu não sei dizer". Acreditamos que a relação das crianças com a escola pode ser mais problematizada pelos profissionais do acolhimento institucional, no sentido de verificar que o direito à educação é mais do que acessar a escola pelas vias da frequência diária, observando como ocorre a permanência de cada aluno no âmbito escolar.

A atenção ao Plano Individual de Atendimento ${ }^{55}$ (PIA) por parte das unidades de acolhimento com todas as professoras que atendem às crianças acolhidas, do $1^{\circ}$ ao $5^{\circ}$ ano, seria um passo para saber como as crianças percebem o papel da escola em suas vidas e o que precisaria ser feito com relação a uma permanência escolar que não lhes seja indiferente ou somente aversiva, mas que permita a aprendizagem. Acreditamos que, mais do que com a escola, termo genérico usado dentro das Otsaca, a figura da professora é imprescindível nessa construção. Com certeza, tal expediente demandaria maior número de técnicos do acolhimento, uma vez que os existentes se encontram sobrecarregados, mas a medida protetiva diz respeito a mais tarefas do que a de ser depositária de segurança física das crianças e guardiã de direitos como a saúde e a educação das crianças. Entremeadas a essas tarefas, umas tantas outras lhes servem de mediação. A execução do PIA na escola seria uma delas.

Sobre o estabelecimento de uma rotina para os deveres de casa e para os estudos de todas as crianças e adolescentes, PUA1 admite haver uma dificuldade em construí-la e mantê-la, pela própria dinamicidade da instituição, onde muitos eventos repentinos acontecem, retirando as profissionais de umas atividades (como o apoio ao dever de casa) e deslocando-as para outras. Em ambas as unidades há espaço para cada acolhido guardar seus pertences da escola, o que contribui para organizar a vida de estudante. Sobre a relação que as unidades de acolhimento travam com a escola (professoras e suas direções), PUA1 afirma que "tem escolas que acham que estão ajudando, mas estão atrapalhando. Tem psicóloga lá dentro (da EEAA) que tem o interesse de ajudar, mas só que, assim, é muita

\footnotetext{
${ }^{55}$ No PIA, cuja execução é de responsabilidade da unidade de acolhimento, constam objetivos, estratégias e ações a serem desenvolvidos tendo em vista a superação dos motivos que levaram ao afastamento do convívio entre a criança e sua família. Várias instituições vinculadas à criança são consultadas para o seu desenvolvimento. (CONANDA/CNAS, 2009).
} 
cobrança em cima da instituição". Ou seja, há disposição para o trabalho junto à unidade de acolhimento, mas não uma oitiva de todas as profissionais sobre as suas limitações no trato cotidiano com as crianças.

Das cinco escolas nas quais a unidade de acolhimento matricula as crianças, PUA1 considera que apenas duas têm uma relação mais positiva. PUA2 afirma que tem uma boa relação com a escola e com cada professora, havendo a troca de números de telefone para que o contato seja imediato sempre que necessário. Em casos que digam respeito a atrasos de alunos ou ausência de uniforme em sala de aula: "Tem uma abertura muito grande entre professores e direção". (UA2 - Entrevista à pesquisadora).

Assim, percebemos que a boa relação é medida por UA2 nas questões de superfície, o que não impede que veja mais conflitos como a seguir.

Sobre o descumprimento de pedidos feitos pela escola à unidade de acolhimento, houve admissão de falhas, inclusive com relação ao dever de casa, nem sempre monitorado pelas cuidadoras: "Tem essa dificuldade de a instituição dar suporte mesmo [...] de dar o acompanhamento mesmo". (PUA1 - Entrevista à pesquisadora).

Por outro lado, PUA2 afirma que a unidade tem dado conta de responder a todas as demandas da escola. A pergunta em contrário, sobre aquilo que a escola não consegue cumprir diante das demandas do acolhimento, recebeu respostas muito distintas. Para a UA2, o grande problema é a questão de faltas dos alunos, que não são comunicadas à unidade de acolhimento, o que acarreta preocupações, principalmente com alunos maiores, que estão fora de faixa, mas frequentam o ensino fundamental. Ressalta que:

O tratamento igual para a criança. É uma parceria no sentido de ver o problema e tentar resolver junto. Ao invés de colocar toda a responsabilidade na instituição, também ver as dificuldades da instituição. Quando a gente passa para eles essas dificuldades, a escola pensa que a gente está dando desculpa. (PUA1 - Entrevista à pesquisadora).

Aqui podemos ver que tanto escolas quanto unidades de acolhimento pouco sabem de si. As escolas (professores e gestores) também admitiram ter dificuldades em lidar com as demandas das crianças acolhidas. Mesmo em um contexto de alienação, ambas são colocadas como políticas para um mesmo sujeito de direitos, no caso, os alunos acolhidos. O que gera dissonâncias, posto que não se reconhecem em seus papéis de modo a operarem conjuntamente. E ambas as instituições carecem não só de um planejamento conjunto, pontual, mas de condições materiais e profissionais para que o trabalho seja feito a contento. 
Não basta só o compromisso com a criança, se não há pessoal suficiente nas unidades de acolhimento para dar conta de demandas tão distintas quanto acompanhar a escolarização de uns e levar outros ao médico. Tampouco há nas escolas profissionais suficientes e habilitados para dar respostas às novas demandas que se colocam hodiernamente como as das crianças sob a medida protetiva de acolhimento institucional, envolvidas em muitas tramas sociais que dificultam sua inserção integral na escola. Não se trata de a escola ter paciência com as limitações das unidades de acolhimento e vice-versa. Mais que qualquer outra avaliação, precisam colocar para si o porquê de tantas precariedades. Souza (2013), abordando as dificuldades da intersetorialidade em políticas sociais, aponta que elas:

Refletem a conjuntura de não ampliação orçamentária das políticas sociais e priorização dos programas de transferências de renda, conferida pela tendência à focalização. Sem a ampliação orçamentária para as outras políticas sociais, os profissionais terão dificuldades no processo da intersetorialidade, ficando a mesma reduzida e restrita a um desejo. (SOUZA, 2013, p. 132).

Debater conjuntamente o problema da falta de recursos para as políticas sociais parece ser mais promissor que a formulação de desculpas pelo não feito ou pelo malfeito entre duas instituições localizadas "na ponta". Quanto aos motivos que geravam mais reclamações sobre os alunos, recebemos três que estão bastante relacionados: os brinquedos, a conduta indisciplinada e a bagunça. A atitude de levar brinquedos à escola é uma das que angariam mais insatisfações por parte dos professores junto a outros comportamentos que fogem à disciplina de sala de aula, que, acreditamos, deve ser construída a partir de decisões junto aos alunos, onde as professoras não fujam ao seu papel de mediadoras privilegiadas.

Certamente há momentos tensos em qualquer sala de aula, mas a priorização do direito à aprendizagem deve ser mantida, mesmo que para isso outras agentes escolares (coordenadora pedagógica, orientadora educacional e direção) se envolvam na construção de patamares de tranquilidade para que se dê continuidade à docência. Quanto aos brinquedos, há de se pensar maneiras de incorporá-los aos planos de aula cotidianos. O brincar é uma atividade importantíssima para que a criança se desenvolva. Ainda conforme Leontiev:

O brinquedo é a atividade principal da criança, aquela em conexão com a qual ocorrem as mais significativas mudanças no desenvolvimento psíquico do sujeito e na qual se desenvolvem os processos psicológicos que preparam o caminho da transição da criança em direção a um novo e mais elevado nível de desenvolvimento. (LEONTIEV, 1998b).

Assim, é preciso que se transforme o brinquedo em uma relação favorável à aprendizagem. Se ele é usado pelas crianças menos como atividade que provoca o raciocínio e 
mais como um artefato produzido pelo consumo, há de se construir regras para o seu uso de qualquer forma, buscando pensá-lo em sua historicidade, sua confecção e seu objetivo (um minigame, um carrinho de polícia ou uma boneca têm diferenças substantivas entre si e também quanto ao seu surgimento). Além de proporcionar diversão e entretenimento:

O brinquedo cria na criança uma zona de desenvolvimento proximal, que é por ele definida como a distância entre o nível de desenvolvimento real, que se costuma determinar através da solução independente de problemas, e o nível de desenvolvimento potencial, determinado através da solução de problemas sob a orientação de um adulto ou em colaboração com companheiros mais capazes. (VYGOTSKY, 1998, p. 112).

E cabe acrescentar que jogos, brinquedos, esportes guardam intimidade com as regras, sendo que a disciplina se constrói por meio delas também. Ou como o próprio Leontiev (1998) analisa: "É através da atividade lúdica que a criança desenvolve a habilidade de subordinar-se a uma regra. Dominar as regras significa dominar o próprio comportamento, aprendendo a controlá-lo e a subordiná-lo a um propósito definido”. (LEONTIEV, 1998, p. 139).

Faz-se necessário, então, que o brinquedo seja redimensionado em seu potencial para situações de aprendizagens, evitando que ele seja alvo de conflitos, podendo ser utilizado para além das classes de alfabetização, como as do $4^{\circ}$ ou $5^{\circ}$ ano. Sobre o que gostariam de ver melhorado na escola no tocante ao atendimento dos acolhidos, houve uma mostra de insatisfação no tratamento das escolas para com as entidades de acolhimento, mas como traço mais incidente aparece a necessidade de a criança ser vista em sua particularidade.

Uma parceria, trabalhar junto com a instituição. Quando a gente for a uma reunião convocada, não será para "eu vou convocar para dizer que eles estão errados e detonar a instituição". Queremos ser chamados para fazer um trabalho junto, em equipe, uma estratégia só. Um plano para cada criança e junto com a instituição, isso seria o ideal. [...] Hoje acontece isso, eles (a escola) empurram o fracasso escolar da criança, como se fosse culpa da instituição (acolhimento)! Porque a criança mora aqui, porque a instituição não dá suporte [...]. (PUA1)

A vivência de rua é diferente. A escola deveria olhar diferenciado, sem discriminar. Ter a preocupação de saber por que as meninas choram em sala de aula [...]. (PUA2)

(Entrevistas à pesquisadora)

A escola mais uma vez é posta em xeque quanto a sua capacidade de agregar a todos democraticamente. Junto às inúmeras tarefas que hoje cabem à professora de ensino fundamental, coloca-se também a de perceber-se em meio à diversidade. A escola pública não pode pertencer a somente um grupo ou classe social. No entanto, como fazê-lo em um 
contexto de alienação? Ainda que diferentes cursos ofertados pela Escola de Aperfeiçoamento dos Profissionais da Educação (Eape) forneçam aos professores e auxiliares de ensino da Secretaria de Educação todo um conteúdo voltado para a compreensão da diversidade humana em seus diferentes aspectos ${ }^{56}$, estamos em meio a um contexto de ascenso de ideias liberais (com fortes apelos para a meritocracia), que compete com uma capacitação aligeirada, principalmente se não for dotada de um viés crítico.

Citamos a dimensão do problema a partir de um exemplo vivido na Secretaria de Educação do DF: a professora foi instada a pensar na diversidade com cursos realizados na Eape; mas, quando recebeu alunos com 13 anos (meninos de zona rural, não acolhidos) para o $5^{\circ}$ ano de escolaridade, que pouco liam e sequer efetuavam contas elementares, soube que sua escola teria a nota da Prova Brasil rebaixada e que o Ideb também seria diminuído em razão disso. De fato houve o rebaixamento. Lidar com isso parece ser uma tarefa coletiva da escola, mas ela nunca foi chamada para conversar sobre o ocorrido e todas as vezes que tentou foi ignorada. Como não levar a problemática como questão individual? E como tal insucesso, não tratado pedagógica e politicamente pelo coletivo escolar, não traria estigma para alunos de mesmo perfil?

Seja a criança acolhida ou não, a ameaça de um resultado ruim proveniente de alunos ou grupos díspares com aquilo que é considerado o ideal mina o projeto de diversidade. Expõe a sua contradição. Há de se pensar a diversidade em um contexto de forte apelo meritocrático, que por diferentes estratagemas colocam os professores para competirem uns contra os outros, em nome de um prestígio muito localizado ou de um $14^{\circ}$ salário, por exemplo. Quanto ao reforço, ambas as escolas dizem levar as crianças quando ele se torna uma necessidade pedagógica para elas.

Ainda que vejam boa vontade em algumas profissionais da escola, não possuem uma boa imagem das escolas como um todo, nem de sua relação com elas. Acreditam que as professoras têm muitas lacunas quanto ao público infantil em acolhimento institucional:

Não está boa. Porque, se fosse precisar criar um plano estratégico com todas as instituições e escolas... Precisa de quê? Os professores precisam de orientação mesmo. Muitos não têm conhecimento do que é uma instituição. Não sabem do trabalho que é desenvolvido. Muitos aqui acreditam que as crianças estão aqui por culpa da própria criança. Ela não está aqui porque foi

\footnotetext{
${ }^{56}$ É importante considerar que Natália Duarte (2013), em sua tese de doutorado, informa que a questão da pobreza não está prevista na ação de formação continuada para fins de organização do trabalho pedagógico das escolas públicas do Distrito Federal, o que torna a compreensão da diversidade bastante restrita para a docência.
} 
negligenciada. Então, falta o quê? Falta uma preparação. Não é uma relação boa, não está sendo um trabalho efetivo [...]. (PUA1)

A relação é boa. [...] Eles são totalmente leigos quando se trata de crianças e adolescentes acolhidos. [...] Pode ser o excesso de coisas na escola (que prejudicam um melhor entendimento). Como são 400 crianças e 15 de abrigo, eles não dão muita importância [...]. (PUA2)

(Entrevistas à pesquisadora)

Independentemente de uma preparação, de uma formação por parte de todos os que trabalham na escola (não somente as professoras) para compreender a problemática da criança acolhida, ela já é um sujeito de direitos, que não podem ser neutralizados por sua condição minoritária na escola. A permanência escolar de cada uma delas deve ser pautada também em suas singularidades frente ao grupo majoritário, caso isso se faça necessário, para que ela não seja hostilizada em sua convivência com toda a comunidade escolar. Afinal, quaisquer alunos têm o direito de ser iguais, quando as suas diferenças os inferiorizam; e o direito de ser diferentes, quando a sua igualdade os descaracteriza.

Sobre o encaminhamento das questões disciplinares pelas escolas, as instituições mostraram-se divididas. PUA2 não reclamou da forma como a escola procedia, disse estar satisfeita. No entanto, PUA1 mostrou-se contrária:

Não porque eles encaminham como se fosse uma acusação. Como se a criança fosse culpada. Ela bagunça porque ela quer, porque ela não tem caráter [...]. A criança agiu com determinada atitude porque ela é ruim, porque ela não tem moral. A instituição (escola) tem que tratar a criança [...] com um trabalho diferenciado. Ela é igual em direitos. Ela não está no seio da família. Ela não tem aquela afetividade, aquela atenção [...]. (PUA1)

(Entrevista à pesquisadora)

PUA2 já havia reclamado dos brinquedos, das chamadas da escola por essa razão, para repreensão dos alunos. No entanto, remetemo-nos novamente à ideia da escola como um tribunal, como um espaço judicializador, o que indispõe as profissionais do acolhimento às narrativas do estigma, tão familiares ao grupo social a que elas prestam atendimento. Nenhuma das unidades cogitou participar do Conselho Escolar de nenhuma das escolas em que as crianças estão matriculadas. Tampouco levou suas demandas para participar da construção do PPP da escola. A demanda por democracia na escola data do século XIX. Marx pronunciava-se da seguinte maneira sobre o assunto, em um texto introdutório, de autoria não assumida:

A crítica de dependência escolar do Estado não tem somente aspectos negativos. A proposta sugerida é de sistema de gestão não burocrático, com a intervenção direta da população trabalhadora através de seus delegados e 
num marco de democracia direta, tal como colocam em relevo suas indicações, já assinalados a propósito da Comuna de Paris. (MARX; ENGELS, 1983, p. 10-11).

As unidades de acolhimento ainda não perceberam que o Conselho Escolar é um espaço importante, podendo influir na maneira como a escola norteia suas ações nas mais variadas frentes e demandas. Inclusive no ato de matrícula das crianças acolhidas, muitas vezes negada sem qualquer motivação, contrariando os dispositivos legais vigentes, o que justificou sua ratificação pela redação da Portaria nº 46/2013 por setores da sociedade civil e Governo do Distrito Federal. O Conselho Escolar de cada unidade de ensino pode resgatar em alguma medida a função pública da escola pública.

Não se trata de uma parceria, de a escola ser parceira de pais ou de alunos. O Conselho Escolar é um órgão "de natureza consultiva, fiscalizadora, mobilizadora, deliberativa e representativa da comunidade escolar", conforme está disposto no art. 24 da Lei n $4.751 / 2012$, que dispõe sobre a Gestão Democrática do Sistema de Ensino Público do Distrito Federal. Particularmente no inciso III do art. 25, está colocado que compete ao Conselho Escolar "garantir mecanismos de participação efetiva e democrática da comunidade escolar na elaboração do projeto político-pedagógico da unidade escolar”, o que abre um cenário de possibilidades para unidades de acolhimento se movimentarem em torno dos direitos das crianças.

A percepção da escola como parceira resulta por inibir a participação qualitativa da comunidade escolar, fazendo com que ela seja uma eventual colaboradora com o serviço de acolhimento, em suas demandas pelo reconhecimento das crianças em sua diversidade, o que obscurece aquilo que é obrigação do Estado, por exemplo oferecer uma escola em que as crianças sempre sejam bem-vindas. Em relação aos motivos que levariam o aluno a evadir da escola ou a ter uma prática pouco proveitosa dentro dela, houve concordâncias das duas representantes das entidades nos seguintes aspectos: desmotivação do aluno, dificuldade com os conteúdos apresentados, estigma sofrido por eles e despreparo da escola para com eles. UA1 afirmou que fatores externos também competiam com a escola, tais como a vivência de rua, acrescida da idade dos alunos. PUA2, por sua vez, assinalou que a falta de acompanhamento dos responsáveis pela criança era um problema para ela, tendo emitido a consideração de que os pais, quando visitam as crianças no acolhimento, dificilmente perguntam sobre a escolarização delas. 
Não houve uma resposta positiva de a escola se articular com o abrigo para ser veículo de proteção das crianças com um caráter mais formalizado. PUA1 afirmou que havia reuniões periódicas para isso, por outro lado, PUA2 afirmou que "a escola não faz, não tem isso". O que se buscava aqui era ver como a escola pensava as crianças caso a caso, se havia um acompanhamento mais minucioso para as crianças, tendo em vista as datas de ingresso delas nas escolas, nem sempre no início do ano letivo, muitas vezes após uma retirada abrupta do lar direto para a unidade de acolhimento. No entanto, nada foi dito nesse sentido, o que de certa forma ajuda a contribuir com uma situação que é quase uma cultura quando se trata das crianças acolhidas: os professores pouco ou nada sabem delas. A proteção na escola é impedida também pelo silêncio que seus responsáveis legais fazem a respeito das trajetórias infantis de cada aluno.

Uma das entrevistadas de nosso pré-teste foi professora de uma criança cuja mãe havia praticado um crime de grande repercussão em Brasília. Ela ficou um ano convivendo com a criança em uma classe de alfabetização, sem ouvi-la proferir uma frase em alto e bom som. Quando houve o desligamento da unidade de acolhimento é que ela teve a noção do que ocorrera na sala de aula, do ostracismo ao qual a criança fora destinada, ponderando aqui e ali sobre a real necessidade de sigilo sobre a criança, mas sabendo que poderiam vir represálias contra ela. No entanto, a maioria das crianças não tem uma infância que imponha tanto segredo, o que acaba por colocar em questão tanto a escolarização quanto o seu caráter humanista. Há uma desconfiança por parte dos trabalhadores das unidades de acolhimento sobre a capacidade de a escola conseguir lidar com histórias trágicas ou muito degradantes sem tornar todo esse enredo a corporificação da criança e, mais grave, sem estigmatizá-la.

A nossa experiência profissional também indica que as crianças acolhidas muitas vezes acabam por esquecer seus locais de nascimento, suas referências comunitárias, os fatos importantes de sua vida quanto mais se envolvem na trama institucional de ocultar os dados de sua infância. Problemas dessa natureza deram origem, por exemplo, ao projeto Fazendo Minha História, o qual tem "como objetivo geral garantir meios de expressão para que cada criança ou adolescente que está em um serviço de acolhimento conheça e se aproprie de sua história passada e presente". (sem data, p. 11). A problematização desse silenciamento ${ }^{57}$ merece um cuidado especial, que coloque em tela a responsabilidade conjunta de professoras

\footnotetext{
${ }^{57} \mathrm{O}$ acolhimento pode durar até dois anos (ECA), ou mais que isso, em casos especiais: tempo longo para pessoas em desenvolvimento viverem em segredo ou silêncio.
} 
e acolhimento em não apagar a vivência da criança, não cerceando o seu direito de falar da própria história, salvo quando isso for ameaçador para ela. O cuidado que aliena a criança de si e dos outros, tornando o papel humanista da educação ainda mais sacrificado, atenta contra a sua integridade.

Ambas as gestoras disseram sentir a falta de profissionais mais preparados no conjunto da rede de ensino (escola, regional de ensino e Secretaria de Educação) para lidar com as questões de aprendizagem/comportamento relativas aos alunos acolhidos. Mais uma vez, o discurso da parceria aparece, desta vez como reconhecimento do que deveria ser uma prática cotidiana. "Sim, eu não quero generalizar, tem muitos professores que fazem uma parceria, que já trabalharam com crianças em acolhimento". (PUA1). Há também uma crítica à falta de informação por parte dos servidores da Secretaria de Educação quanto à tramitação de projetos de lei, de sua promulgação, da publicação de portarias e de outros fatos dessa natureza:

Sinto, até porque tem a portaria que fala do acolhimento institucional e a regional não tem conhecimento. A portaria é desconhecida pelos próprios funcionários da Secretaria de Educação. Eu tive que ficar rodando quinze dias para transferir duas crianças de escola, porque eles não tinham conhecimento dessa portaria (Portaria $\left.\mathrm{n}^{\circ} 46\right)[\ldots]$. (PUA 2)

A crítica, ainda que procedente, pois se relaciona com a violação de direitos, não é capaz de eliminar as barreiras existentes para que a informação circule democraticamente dentro da Secretaria de Educação, situação que prejudica alunos e professores simultaneamente, tendo se revelado como óbice, inclusive, em nossa pesquisa. A falta de informações atinge também os membros das secretarias escolares e gestores, como pudemos observar em reiteradas ocasiões, pessoas diretamente implicadas com as decisões da referida secretaria. Vimos, no decorrer das entrevistas, um assoberbamento de tarefas, particularmente para as professoras do $1^{\circ}$ ao $3^{\circ}$ ano, com as atividades do curso do Pnaic, a sala de aula, projetos interventivos e o reforço escolar.

As reuniões de coordenação coletiva, feitas em um prazo de três horas, atualizavam as professoras sobre demandas recentes, mas era difícil imaginar como estariam todas informadas permanentemente sobre portarias de quaisquer naturezas dentro do volume de atividades desenvolvidas, que vão se somando a outras de última hora, não raras vezes, oriundas não se sabe exatamente de onde, encaminhadas não se sabe por quem, o que vem ocorrendo em todo o serviço público. Lemos (2006) analisa, por exemplo, o magistério em nível superior num contexto de universidade pública: 
Na prática pedagógica alienada o professor realiza um trabalho que não lhe pertence no sentido humano, não pode convertê-lo em elementos da sua própria vida. $\mathrm{O}$ trabalho torna-se um meio de assegurar sua existência e então acaba realizando o que é encomendado e, mais que isso, reproduzindo o pensamento dominante. O que sobra é somente uma sujeição às suas necessidades individuais e a dificuldade de participar de objetivos comuns e nesse sentido vai se isolando. O resultado é a alienação do aluno pela falta de um vínculo intersubjetivo que relacione o modelo pedagógico e as demandas da prática social. É nesse momento que o trabalho se torna coisa e o professor deixa de fazer a sua história e humanizar-se. (LEMOS, 2006, p. 10).

Diante desse quadro, o trabalho interinstitucional passaria em primeiro lugar pela partilha de informações e de conhecimentos sobre o intrincado funcionamento da escola, das unidades de acolhimento e das Secretarias de Educação e de Assistência Social, passando pelo corte de arestas construídas pela incompreensão dos papéis dos trabalhadores envolvidos com a escolarização dessas crianças. As escolas ainda não planejam suas atividades pedagógicas junto às unidades de acolhimento, o que é lamentado pelas últimas:

Não! Se criassem estratégias junto, eu acho que a instituição teria muito a oferecer à escola. [...] Tem muita coisa que a escola faz, que não faz parte da realidade das crianças. Nós podemos dizer o que pode estimular a criança a participar [...]. (PUA1)

Não, não! Um ou outro professor que tem interesse em conhecer a realidade das crianças [...]. (PUA2)

(Entrevistas à pesquisadora)

As últimas afirmativas mostram que há um longo caminho a se perseguir para que escolas se aproximem mais das unidades de acolhimento com vistas a um trabalho comum. A apreensão de que cada aluno, e os acolhidos em especial, se constitui em um complexo sócio-histórico-cultural evoca a escola a conhecê-los mais em suas trajetórias pontuadas por perdas, dores e violações, dando um viés crítico às apreensões colocadas, o que deve vir em benefício do planejamento das atividades em classe e de todo o planejamento dentro do calendário escolar, ao mesmo tempo em que a aproximação solicita das unidades de acolhimento maior abertura para entender os limites e possibilidades da escola em um contexto extremamente desfavorável, sobretudo para os professores, bastante demandados na rotina escolar. Ao acercar-se da escola, as unidades de acolhimento teriam mais possibilidades de construir os planos de atendimento (PIA) para os alunos, bem como participar de maneira ética e compromissada do andamento dos processos de acolhimento de cada um deles, mostrando se caminham para um retorno à família ou para uma adoção. 
Uma das imagens indeléveis de nossa pesquisa foi o chamado pesaroso de uma professora que foi entrevistada por nós no ano passado. Em uma nova visita que fizemos à escola para uma revisão de dados, ela nos interpelou em particular para dizer que o seu "aluno-destaque" (ótimo, segundo ela), de sete anos, havia sido desligado do acolhimento sem sequer se despedir dela, pois não houve o cuidado da unidade de acolhimento em promover a separação do garoto de sua turma e de sua professora. Como se tratava de uma turma de $1^{\circ}$ ano de escolaridade, o envolvimento com o aluno costuma ser mais estreito, o que fez com que ela se sentisse uma "laranja que perdeu todo o sumo e foi descartada". Murmurava que não sabia se ele havia sido adotado ou se voltara para a família.

Os papéis humanistas da escola e da unidade de acolhimento veem-se diminuídos em episódios como esses, danosos para todos os envolvidos na escolarização da criança, por melhor aluno que ele tenha conseguido ser. No capítulo 4, daremos prosseguimento às entrevistas que fizemos com os gestores que ocupam cargos nas pastas de Assistência Social e Educação em níveis distrital e federal. 


\section{CAPÍTULO 4}

\section{AS POLÍticAs DISTRITAL E FEDERAL PARA A ESCOLARIZAÇÃO DOS ALUNOS ACOLHIDOS}

Após o trabalho de campo junto às professoras e gestoras de escolas e às coordenadoras de instituições de acolhimento realizado no capítulo anterior, buscamos saber dos esforços empreendidos pelo Governo Distrital (SEDF e Sedest) e Federal (MEC e MDS) a fim de garantir uma permanência escolar exitosa para os alunos acolhidos, bem como saber sobre o monitoramento das políticas desenvolvidas para esse fim, resguardadas as diferentes responsabilidades constitucionais de cada um.

Realizamos, assim, uma pesquisa documental sobre possíveis políticas voltadas para a efetivação da permanência dos alunos acolhidos e entrevistamos duas gestoras distritais, uma pertencente à pasta de educação do Núcleo de Cidadania, Educação e Direitos Humanos e outra da pasta de Assistência Social da Gerência de Acolhimento para Crianças e Adolescentes, ambas como formação específica para as suas áreas de atuação e servidoras efetivas da SEDF e Sedest respectivamente. Algumas impressões emitidas pelas entrevistadas estão inseridas no corpo do capítulo. Após as análises do material obtido localmente, procederemos à discussão acerca das ações realizadas nesse sentido pelo Governo Federal.

Cabe destacar que nas Otsaca está previsto que a articulação entre as políticas sociais distritais e federais pode ocorrer apenas mediante elaboração conjunta de um protocolo de ação entre o órgão gestor da Assistência Social e da Educação, a fim de que se garanta a permanente comunicação entre os serviços. Uma previsão que visa a promover conjuntamente:

$\mathrm{O}$ acesso das crianças, adolescentes acolhidos e seus familiares à rede local de educação. Assim, os serviços de acolhimento devem manter canais de comunicação permanentes com as escolas onde estejam matriculadas as crianças e os adolescentes acolhidos, de modo a possibilitar o acompanhamento de seu desempenho escolar. (CONANDA/CNAS, 2009, p. 47). 
De antemão, viemos a saber por meio da ONG Berço da Cidadania que no Distrito Federal as discussões intersetoriais vinham passando pela construção de um grupo de trabalho (GT) constituído por membros das pastas de Assistência Social e Educação, que passou a existir sem uma institucionalização formal desde 2012. Trata-se do GT Educação/Serviços de Acolhimento.

O referido GT é constituído pelos seguintes segmentos: a) Servidores da Assistência Social que atuam na gestão assistencial $^{58}$ e em unidades públicas de acolhimento; b) Servidores da Educação que atuam na gestão educacional ${ }^{59}$, em unidades escolares e no acolhimento (caso único de pedagoga da SEDF cedida); e c) Técnicos do Instituto Berço da Cidadania (IBC) ${ }^{60}$, organização atuante como Oscip na área de acolhimento de crianças e adolescentes no Distrito Federal. Segundo a gestora da Assistência Social entrevistada na presente pesquisa, o GT é produto de discussões anteriores mais amplas, onde ambas as secretarias e diferentes unidades de acolhimento, públicas e privadas, envolvidas em debates sobre o acesso e a permanência dos alunos acolhidos em toda a educação básica, avaliaram a necessidade de um maior preciosismo por parte do atendimento das crianças e adolescentes nas escolas públicas do Distrito Federal. Esse grupo reúne-se sem uma regularidade fixa, mas tem uma agenda de trabalho contínua.

Cumpre dizer que a titular desta tese tem participação nas discussões do referido GT desde meados de 2012, não tendo ainda encerrado sua atuação. A participação aconteceu por meio de convite do referido IBC, a fim de que contribuísse com o debate travado pelo grupo de trabalho, particularmente na realização de oficinas junto aos servidores da Secretaria de Educação e Sedest. A contribuição seria fornecida com o objetivo de explicitar as especificidades dos alunos acolhidos dentro do ECA, visando a ampliar as possibilidades de as escolas realizarem junto às unidades de acolhimento um trabalho mais qualificado com esse grupo de alunos. Não pretendemos, no entanto, tratar de todas as questões abordadas nas discussões do GT, até porque muitas escapam aos anos iniciais do ensino fundamental, mas entendemos que a construção da Portaria n 46, de 7 de março de 2013, que diz respeito ao

\footnotetext{
58 Particularmente na Gerência de Acolhimento para Crianças e Adolescentes, a qual está inserida na Subsecretaria de Assistência Social (Subsas).

${ }^{59}$ Particularmente o Núcleo de Cidadania, Educação e Direitos Humanos, o qual está inserido na Subsecretaria de Educação Básica (Subeb).

${ }^{60}$ Conforme o site do IBC na internet, a Oscip "promove ações preventivas, intervenção e acompanhamento, assegurando a convivência familiar e comunitária de crianças e adolescentes em situação de vulnerabilidade e risco, implementando práticas que previnam o acolhimento institucional ou que assegurem cuidados de qualidade. Otimiza o trabalho de reintegração e promove ações para autonomia dos adolescentes".
} 
acesso e permanência de estudantes acolhidos em escolas públicas, foi a realização mais importante deste trabalho coletivo até o encerramento da presente tese.

\subsection{A Portaria $n^{0}$ 46, de 7 de março de 2013: possibilidades e limites}

Uma das recorrentes reclamações "da ponta", ou seja, das unidades de acolhimento à Sedest durante diversos fóruns de discussão sobre acolhimento ${ }^{61}$ dizia respeito à dificuldade em matricular alunos sob a medida de proteção de acolhimento, informações que coincidem com o relato da gestora da área da Assistência por nós entrevistada nesta pesquisa. A discriminação sofrida no processo de matrícula era aventada pelas profissionais das unidades, nos referidos espaços de discussão, as quais se diziam aviltadas com a negativa da existência de vagas pela escola quando elas próprias já haviam verificado o contrário. No caso de efetivação da matrícula, verificava-se novamente o descontentamento das profissionais em razão de muitas das crianças por elas acompanhadas viverem, em seus cotidianos escolares, situações discriminatórias por não estarem inseridas em um contexto familiar, por serem consideradas "crianças abandonadas", entre outros assédios de semelhante matiz.

Dessa forma, em meados de 2011, a Sedest foi o órgão gestor que teve a iniciativa de procurar a SEDF para juntas pensarem políticas com o objetivo de reverter o quadro insatisfatório vivido pelas entidades de acolhimento, seus profissionais e acolhidos, no processo de escolarização. Esse processo teve início porque a Sedest, diante da necessidade de reordenamento $^{62}$ dos serviços de acolhimento rumo a sua desinstitucionalização, percebia como uma necessidade a aproximação com a rede de proteção, a fim de que ela acompanhasse as mudanças em curso, possibilitando um trabalho mais qualificado junto aos acolhidos.

Esta aproximação foi demorada, segundo o relato da gestora da SEDF. O convite para o encontro com toda a rede fez com que os profissionais da gestão verificassem as suas limitações (e do próprio órgão) para um debate de bom nível sobre o acolhimento

\footnotetext{
${ }^{61}$ Cursos de formação, seminários distritais e eventos acadêmicos.

${ }^{6}$ O Plano Nacional de Promoção, Proteção e Defesa do Direito de Crianças e Adolescentes à Convivência Familiar e Comunitária (PNCFC) sinaliza para o reordenamento das instituições que oferecem o serviço de acolhimento institucional. No documento há a defesa da profissionalização dessas entidades e dos cuidadores, bem como o respeito ao postulado ECA para esse tipo de atendimento. Além disso, o plano tem como proposição executar alternativas desinstitucionalizantes, a exemplo dos programas de famílias acolhedoras, com vistas a propiciar a convivência familiar e comunitária, mesmo para as crianças e os adolescentes afastados temporariamente de suas famílias de origem.
} 
institucional, adiando o encontro para meses depois. A discussão interna, feita para ter maior embasamento sobre os estudantes a respeito da medida de proteção de acolhimento e o seu direito à escolarização dentro da SEDF, foi o elemento que propiciou ao Núcleo de Cidadania, Educação e Direitos Humanos uma retomada do contato com a Sedest, meses depois, já em 2012, na segunda metade da gestão do governador Agnelo Queiroz. Essa retomada vem viabilizando o trabalho do GT, que atualmente busca divulgar a Portaria $n^{\circ} 46$ em seus pormenores.

Em nossa análise, discutiremos os pontos mais relevantes da portaria, destacando aspectos da realidade que encontramos nas escolas, buscando apontar elementos que poderiam ser constitutivos de um texto mais aprimorado. Considerando toda a legislação vigente (o ECA, a resolução que dá sustentação às Otsaca, o PDCFC, entre outros instrumentos), a Portaria $n^{0} 46$ institui em seu primeiro artigo: “A Política de Inclusão Educacional e Acompanhamento da Escolarização de Crianças e de Adolescentes em Acolhimento Institucional com igualdade de condições e oportunidades para o acesso e permanência nas Unidades Escolares”.

Dessa maneira, essa política passa a orientar o conjunto de escolas da SEDF quanto a procedimentos envolvendo a matrícula e o acompanhamento do processo de escolarização de crianças e adolescentes sob medida de acolhimento institucional no âmbito do Distrito Federal. Cabe, assim, à SEDF, como integrante da Rede de Proteção Social e do Sistema de Garantia de Direitos, em relação às citadas crianças e adolescentes, garantir a escolarização, assegurando-lhes, conforme o art. $3^{\circ}$ da referida portaria:

I - igualdade de condições para o acesso e a permanência na Escola, na etapa e modalidade que melhor atenda às suas necessidades;

II - direito de ser respeitado por todos os servidores da Escola e estudantes;

III - direito de contestar critérios avaliativos, podendo recorrer a instâncias escolares superiores, quando as locais não lhe responderem às expectativas;

IV - direito de organização e participação em entidades estudantis;

V - acesso à escola pública e gratuita próxima à Unidade de Acolhimento e, no caso de reintegração familiar ou inclusão em família substituta, próxima à residência de sua família;

VI - Ensino Fundamental, obrigatório, gratuito, com êxito e qualidade social, inclusive para os que não tiveram acesso na idade própria;

VII - atendimento educacional especializado, quando as condições assim o exigirem;

VIII - atendimento prioritário em instituições de Educação Infantil; 
IX - acesso aos níveis mais elevados do ensino, da pesquisa e da criação artística, segundo a capacidade de cada um;

$\mathrm{X}$ - oferta de ensino noturno regular, adequado às condições do adolescente trabalhador;

XI - atendimento no Ensino Fundamental, através de programas suplementares de material didático-escolar, uniforme, transporte, alimentação e assistência à saúde, quando as condições assim o exigirem.

Dessa maneira, fica subentendido pela portaria que o suprimento de materiais didáticos e congêneres, assim como o cumprimento dos direitos relativos à igualdade e à dignidade junto aos demais alunos (entre outros elencados), seria propulsor de uma escolarização mais condizente com uma educação de qualidade. No entanto, apesar do empenho do GT em construir tal dispositivo, a dimensão do trabalho em sala de aula não foi desenvolvida, o que se verifica como uma lacuna: essa dimensão que diz respeito não somente aos planos de ensino, mas também às condições que a escola possui para construir um PPP bem embasado teoricamente, que venha a incorporar as demandas dos estudantes em acolhimento.

Neste contexto é preciso considerar a grande quantidade de demandas que está colocada para a escola e seus profissionais, situação análoga à das unidades de acolhimento, que acabam sempre recorrendo a voluntários para dar conta da escolarização das crianças e adolescentes sob a sua proteção. Ambas as gestoras distritais entrevistadas disseram que política pública se faz com pessoas, admitindo que há a necessidade de mais profissionais para que se viabilize o direito social previsto no dispositivo.

De qualquer maneira, faz-se necessário pensar o planejamento das atividades em classe para um sujeito concreto, que é apenas superficialmente conhecido, um aluno genericamente vinculado "ao abrigo", como ficou explícito nos dados obtidos pela pesquisa. Ao pensarmos no trabalho docente, entendemos como necessário que se garantam conteúdos que não reiterem o que está dado pelo contexto social do aluno, ou seja, aquilo que ele pode conhecer sem frequentar a escola. Não se trata de negar tal contexto, de omiti-lo, mas de não o confirmar em detrimento de novas objetivações.

A finalidade do trabalho docente consiste em garantir aos alunos acesso ao que não é reiterativo na vida social:

Dito de outra forma, o professor teria uma ação mediadora entre a formação do aluno na vida cotidiana onde ele se apropria, de forma espontânea, da linguagem, dos objetos, dos usos e dos costumes, e a formação do aluno nas esferas não cotidianas da vida social, dando possibilidade de acesso a 
objetivações como ciência, arte, moral, etc. [...] e possibilitando, ao mesmo tempo, a postura crítica do aluno. (BASSO, 1998).

Entretanto, parece inócuo pensar em uma ação mediadora junto a um aluno que é desconhecido em sua concretude no contexto social em que está inserido, tal como a pesquisa nos revelou no capítulo anterior. Para Duarte (2007), para efetivar plenamente seu trabalho educativo, o professor precisa:

Manter uma relação consciente para com o papel do trabalho educativo na formação daquele indivíduo-educando-concreto que tem diante de si e para com as implicações desse trabalho educativo na produção e reprodução da vida social. Em outras palavras, não basta formar indivíduos, é preciso saber para que tipo de sociedade, para que tipo de prática social o educador está formando indivíduos. (DUARTE, 2007, p. 51).

Uma necessidade que demanda um trabalho pedagógico capaz de afugentar o pragmatismo e que esteja voltado precipuamente para o aluno, para o desenvolvimento de suas capacidades intelectuais, em que pesem seus obstáculos e dificuldades pessoais. Não se perde de vista aqui quão contraditório é trabalhar com o alunado em sua concretude diante do conjunto de tarefas hoje colocadas para a docência. Isso porque estamos particularmente em um contexto em que a pressão por desempenho nas avaliações institucionais como a Avaliação Nacional de Alfabetização (ANA), a Provinha Brasil e a Prova Brasil parece apontar para um pragmatismo em sala de aula. Algo que Freire (1995) já denunciava ao final do século passado: "Negando à prática educativa qualquer intenção desveladora, reduzem-na à pura transferência de conteúdos 'suficientes' para a vida feliz das gentes. Consideram feliz a vida que se vive na adaptação ao mundo sem raivas, sem protestos, sem sonhos de transformação". (FREIRE, 1995, p. 27).

O enfrentamento é, no entanto, no sentido de realizar um trabalho docente crítico, ainda que em conjuntura desfavorável. Tudo parece colaborar para a destituição do caráter humanista da escola, ao mesmo tempo em que as lutas pela democratização do acesso e permanência pedem exatamente o contrário.

Até o presente momento, identificamos a escassez de conhecimento por parte das profissionais da educação que atuam diretamente com alunos acolhidos. Assim, cada um dos incisos da portaria teria mais efetividade se houvesse a capacitação contínua dessas profissionais para compreenderem as "medidas protetivas" e a sua repercussão em meio escolar. Uma capacitação que se tornaria mais potente se realizada conjuntamente com as profissionais das unidades de acolhimento, no intuito de proporcionar a quebra de indisposições entre elas, como verificado nos dados apresentados no capítulo anterior. 
Muitos dos profissionais que trabalham na escola não sabem que a medida protetiva opera como um recurso provisório e excepcional, de no máximo dois anos, e que busca sobretudo a reintegração familiar. A adoção é a última medida utilizada para resguardar a criança ou o adolescente, quando as possibilidades de convivência com a família se veem esgotadas. Essa incompreensão acaba por acarretar situações constrangedoras para as crianças, que em nada colaboram para o seu desenvolvimento dentro da situação singular em que estão inseridas. Muitas trabalhadoras das unidades de acolhimento desconhecem as rotinas e afazeres da escola, não podendo colaborar com elas a contento, nem mesmo discordar com bons argumentos.

Assim, por difícil que seja o encontro interinstitucional, as situações demandadas pela escolarização dos alunos precisam sofrer mediações que promovam o seu bem-estar dentro da escola, partindo para uma compreensão que vá para além da aparência, das generalizações que se fazem sobre o estudante acolhido. Não se trata de dizer que "cada caso é um caso", ainda que isso se verifique, mas de investir na compreensão de que as histórias infantis atravessadas pelo acolhimento são produtos de um Estado historicamente omisso e buscar o cumprimento dos direitos aos quais as crianças fazem jus desde a promulgação do ECA.

Como já foi mencionado, ainda não existe um protocolo mínimo para receber uma criança acolhida na escola, algo que é previsto ${ }^{63}$ quando do ingresso na unidade de acolhimento institucional, fato que faz com que sua inserção varie de escola para escola, pela ausência de um procedimento padronizado que a leve a conhecer a unidade de ensino e seus componentes: docentes, auxiliares de ensino, orientadores educacionais e demais membros da comunidade escolar, da mesma maneira como se faz no início do ano letivo com os demais alunos. As crianças acolhidas, não raras vezes, adentram a escola com períodos letivos iniciados, o que impede que sejam inseridas com os mesmos rituais de boas-vindas daqueles que frequentam a escola desde o primeiro dia de aula.

\footnotetext{
63 Diante do impacto que o acolhimento possa representar na vida de uma criança ou adolescente, alguns cuidados são previstos nas Otsaca, para que não vejam a medida protetiva como uma punição, ocasionando sentimento de revolta e rejeição. Na resolução do Conanda/CNAS está previsto: “deve-se dar especial atenção ao momento de acolhida inicial da criança/adolescente, no qual deve ser dado tratamento respeitoso e afetuoso, apresentar-lhes, inclusive, o espaço físico, as crianças e os adolescentes que lá se encontram, seu educador/cuidador de referência - ou membros da família acolhedora - e seu espaço privado (cama, armário, etc.)". (Conanda/CNAS, 2009, p. 51). Havendo também a preocupação de mostrar as regras da unidade de acolhimento de maneira gradativa.
} 
Uma formação voltada para os direitos do educando possibilitaria também às cuidadoras-educadoras e ao restante da equipe do acolhimento questionar avaliações e o conteúdo dos deveres de casa, por exemplo. Afinal, apelar contra procedimentos escolares é um exercício de direito ainda mal interpretado, visto como enfrentamento à escola e aos professores. Não sendo um ato de simples execução, o questionamento requer apoios para que o aluno o exerça.

Apesar do esforço do GT de assegurar direitos, o trabalho de campo nos permitiu perceber que se faz necessária toda uma circulação de conhecimentos e informações que ainda não estão presentes no dia a dia das unidades de acolhimento e das escolas, informações que poderiam ser compartilhadas, mediante um calendário que reunisse a escola e a unidade de acolhimento sob os auspícios dos órgãos gestores da Educação e da Assistência Social. Com certeza aconteceriam tensões nesse processo, algumas de grau elevado. No entanto, o esforço tem sentido quando se pretende, particularmente para o acolhido, uma escola que transcenda à mera oferta do acesso obrigatório, não raras vezes acompanhada de uma permanência desengajada.

A Portaria $n^{\circ} 46$ reitera a proibição de se negarem vagas a esses alunos em função da falta de documentos ou de seus responsáveis legais, ressaltando a necessidade de que sejam matriculados próximos à unidade que os acolhe, entre outros aspectos já contemplados na legislação em vigor. Ainda no encerramento da pesquisa, ao final do ano de 2013, assistimos ao descumprimento do direito à matrícula, de acordo com queixas tanto de instituições de acolhimento públicas quanto privadas proferidas em reuniões do GT.

Quanto à previsão de que os alunos fossem encaminhados à EEAA quando da ocorrência de problemas de aprendizagem com vistas a garantir o "desenvolvimento e a permanência com êxito do estudante na escola", conforme o art. 14 da portaria, observamos que o procedimento já vinha sendo efetuado na escola anteriormente à sua edição. No entanto, acreditamos que um Plano de Atendimento Individual, assemelhado ao PIA, não deva ocorrer somente quando se detectam problemas com a aprendizagem e/ou socialização, mas independentemente disso, tão logo o aluno se matricule na escola, uma generalização que foge ao artigo.

A gestora da SEDF expôs, como óbice para que isso ocorra, o temor de se construírem estigmas em torno do estudante, conforme debate travado com a Sedest quando da construção da portaria. No entanto, o dever ético dos profissionais da educação deve se sobrepor a preconceitos e discriminações, devendo-se assegurar o direito do aluno à proteção que lhe é mais condizente, inclusive porque o PIA já existia como formulação, anteriormente, dentro do corpo das Otsaca. 
As dificuldades técnicas para executá-lo escola a escola, aluno por aluno, não precisam ser acrescidas de temores que podem ser revertidos com um trabalho construído conjuntamente.

$\mathrm{O}$ art. 15 da portaria prevê que os casos de dificuldade com o comportamento disciplinar dos estudantes devem ser tratados com eles mesmos e com as unidades de acolhimento, o que também vimos ocorrer nas cinco escolas visitadas, ainda que houvesse reclamações das unidades de acolhimento quanto ao tratamento mais rigoroso quando o aluno era um assistido, o que cabe ser problematizado em benefício de todos os alunos da escola.

Por último, está disposto na portaria que o Núcleo de Cidadania, Educação e Direitos Humanos da Coordenação de Educação em Direitos Humanos (NCEDH) da SEDF, em articulação com a Diretoria de Serviços de Acolhimento (Disa) da Sedest, promoverá semestralmente uma avaliação do funcionamento desta rede, conforme o art. 20, que finaliza a Política de Inclusão Educacional e Acompanhamento da Escolarização de Crianças e de Adolescentes em Situação de Acolhimento Institucional, avaliação que se ateria apenas ao plano do atendimento pedagógico, buscando conhecer o cumprimento daquilo estabelecido pela portaria, fato que já requer um entrelaçamento maior entre as secretarias, tendo em vista que somente a Sedest mantém, com alguma atualização, a listagem das escolas que alunos em acolhimento frequentam.

\subsection{Sobre a avaliação da política}

Como vimos, a avaliação prevista na Portaria $n^{\circ}$ 46, de 7 de março de 2013, ocorrerá apenas no plano pedagógico, já que o foco da portaria se resume a esse aspecto. Assim, uma avaliação detalhada, para além dos aspectos pedagógicos, ainda não foi objeto de discussão nem de elaboração: uma avaliação onde figurem as escolas, o número de ingressos de acolhidos em cada uma, bem como o rendimento de cada aluno, possíveis evasões, dentre outros aspectos. Um monitoramento poderia subsidiar a avaliação mais amiúde, corrigindo distorções, acompanhando sistematicamente o que está disposto na portaria, entendendo-se monitoramento como um:

Acompanhamento contínuo, cotidiano ou periódico, realizado por gestores e gerentes de programas e políticas em relação aos seus processos, objetivos e metas. É um procedimento inerente à gestão dos programas/políticas que permite a adoção de medidas corretivas para melhorar sua operacionalização. (ROLIM, 2009, p. 80). 
Este recurso envolveria, segundo a gestora da NCEDH, um preparo das Coordenações Regionais de Ensino (CRE) para atuarem junto às escolas, colhendo esses dados com frequência. Isso porque o NCEDH não trabalha com as escolas diretamente, mas com as CREs. Uma articulação entre a Subsecretaria de Educação Básica (Subeb), afeita ao trabalho pedagógico, junto à Subsecretaria de Planejamento, Acompanhamento e Avaliação (Suplav), que tem entre suas atribuições planejar, acompanhar e avaliar o acesso e a permanência dos alunos na rede pública de ensino, como também realizar pesquisas e estudos com vistas a subsidiar a implementação de políticas públicas, programas e projetos da Secretaria de Educação do Distrito Federal.

Para tanto, entendemos que todo o trabalho da SEDF teria de estar articulado com o da Sedest, dentro daquilo que a esta última caberia partilhar com a primeira, tendo em vista que a vida de alguns alunos acolhidos é interpelada por situações de ameaça, como aqueles que estão inseridos no Programa de Proteção a Crianças e Adolescentes Ameaçados de Morte (PPCAAM), entre outras possibilidades de restrição: reservas que podem envolver o Poder Judiciário e requerem confidencialidade sobre os dados dos alunos.

É preciso ponderar que mesmo a Sedest ainda não tem condições de saber quantos adolescentes e crianças existem nas unidades de acolhimento do Distrito Federal. Tal informação depende de um cadastramento ${ }^{64}$, a ser alimentado com rigor pelo Judiciário a cada expedição de uma guia de acolhimento para criança ou adolescente, sendo que há crianças e adolescentes acolhidos que não passaram pelas autoridades judiciárias ${ }^{65}$ para estarem sob a medida de proteção de acolhimento. Conforme a gestora da Sedest, atualmente a Diretoria de Serviços de Acolhimento (Disa) não consegue fazer o acompanhamento individual da escolarização de cada aluno acolhido, mesmo os que estão visibilizados, inclusive os de unidades governamentais. Daí decorre a dificuldade de a mesma diretoria saber de maneira mais sistemática e precisa qual instituição está sendo exitosa nos processos de escolarização

\footnotetext{
${ }^{64}$ A Resolução no 93 do Conselho Nacional de Justiça, de 27 de outubro de 2009, dispõe que esse conselho implantará o Cadastro Nacional de Crianças e Adolescentes Acolhidos com o objetivo de "consolidar dados de todas as Comarcas das Unidades da Federação referentes a crianças e adolescentes em regime de acolhimento institucional ou familiar no país".

${ }^{65}$ Um relatório do Conselho Nacional do Ministério Público (CNMP) apontou que em 27,9\% das entidades de acolhimento institucional visitadas há registro de criança e/ou adolescente encaminhados ao serviço sem guia de acolhimento expedida pela autoridade judiciária. Mais dados sobre o relatório em: <www.cnmp.mp.br/portal/noticia/3702-cnmp-divulga-dados-sobre-acolhimento-de-criancas-e-adolescentes $>$.
} 
de seus acolhidos. Importa dizer que nem mesmo sobre os processos de reintegração ao lar há dados monitorados. ${ }^{66}$

Há uma malha de óbices impedindo o monitoramento/avaliação, tanto do processo pedagógico com os alunos acolhidos quanto de dados que indiquem ingresso, aprovação, evasão, rendimento, entre outras possibilidades. São obstruções: a) de ordem técnica, uma vez que se faz necessário um sistema para viabilizar tal monitoramento; b) de ordem judicial, tendo em vista a necessidade de sigilo total sobre alguns acolhidos e de manter um Cadastro Único alimentado diariamente; c) de ordem política, porque as informações (disponíveis) sobre os acolhidos estão em poder do órgão gestor da Assistência Social; e d) de ordem cultural, pois é preciso manter a rotina de alimentar e cobrar dados sobre o desempenho desses alunos.

\subsection{A divulgação da Portaria $n^{\circ}$ 46, de 7 de março de 2013}

O empenho por construir a Portaria $n^{\circ} 46 / 2013$ foi acompanhado de medidas para sua divulgação que ultrapassavam a sua mera publicação. Afinal, continuaram havendo queixas das unidades de acolhimento quanto aos procedimentos de matrícula, dificultados por diversas escolas em todo o Distrito Federal. Por esse motivo, o GT procedeu a um trabalho de divulgação em diferentes coordenações regionais de ensino, por vezes agrupando-as, como no caso de Ceilândia e Taguatinga, ou do Gama e Recanto das Emas. Nesses momentos, reuniam-se com distintos arranjos os representantes da Sedest (nível central) e da SEDF (nível central e membros das coordenações regionais de ensino); da ONG Berço da Cidadania, com diferentes profissionais do acolhimento institucional (coordenadoras, cuidadoras-educadoras); e das escolas (orientadoras educacionais, gestoras). Os convites eram enviados por e-mail às unidades de acolhimento e de ensino e reforçados por telefonemas pela gestão central. As reuniões tinham o formato de oficinas e visavam, além de informar sobre a portaria, a justificar a sua existência por meio de um apanhado histórico sobre o acolhimento institucional, frisando a importância da convivência familiar e comunitária, aspectos negados

\footnotetext{
${ }^{66}$ Embora o monitoramento esteja previsto na Norma Operacional Básica do Suas-NOB/Suas (2004) como uma responsabilidade de aprimoramento do próprio Suas: "instalar e coordenar o sistema do Distrito Federal e estabelecer indicadores de monitoramento e avaliação de todas as ações da Assistência Social por nível de proteção social, básica e especial, em articulação com o sistema nacional”. (BRASIL, 2004, p. 106). Além de "coordenar e cofinanciar o sistema de informação, monitoramento e avaliação do Distrito Federal, alimentando as bases de dados informatizados, provenientes do subsistema da rede Suas”. (Idem, Ibidem).
} 
em um passado anterior ao ECA, em que a vida asilar era o destino de crianças e adolescentes que tinham vidas dissonantes do padrão hegemônico.

$\mathrm{Na}$ oportunidade, profissionais das coordenações regionais de ensino, das escolas e unidades de acolhimento eram apresentados uns aos outros para que travassem contatos e construíssem agendas de trabalho, no sentido de fazer valer a portaria. As oficinas não tiveram a receptividade esperada, fato que se deveu à falta de muitos representantes das escolas, por vezes até de representantes das unidades de acolhimento. No entanto, elas se realizaram mesmo assim, propiciando uma troca de informações e de experiência entre servidores da Educação, da Assistência Social e das unidades de acolhimento, deixando claras, por algumas vezes, as tensões existentes, por exemplo a queixa da excessiva cobrança que a escola faz para as unidades de acolhimento. A mais nova modalidade de divulgação da portaria vem acontecendo nas coordenações coletivas de orientadoras educacionais, por regional de ensino.

Um desafio que acreditamos ser importante neste processo é a realização do Plano Individual de Atendimento (PIA) para cada estudante acolhido, o que requer um número maior de profissionais das unidades de acolhimento com vistas ao desenvolvimento de atividades junto às diversas escolas. Acreditamos que tal tarefa demandará esforços tanto da Sedest quanto da SEDF para municiarem tecnicamente as unidades de acolhimento e escolas, respectivamente, sobre a importância desses instrumentos, não somente para acompanhar o desenvolvimento do acolhido no decorrer da medida de proteção, mas para avaliar longitudinalmente a sua permanência na escola. Seria uma tarefa que contribuiria para maior conhecimento dos alunos por parte da escola, possibilitando de maneira mais efetiva sua almejada proteção. Para tanto, faz-se necessária a construção de uma articulação mais desarmada entre escolas e unidades de acolhimento, a fim de transformarem a cultura de desconfiança sobre os seus papéis na vida das crianças, rumo a um trabalho mais comprometido com elas, quiçá menos alienado.

\subsection{O Governo Federal e a articulação intersetorial em torno da escolarização de crianças e adolescentes acolhidos}

No âmbito do Governo Federal, a publicação em 17 de junho de 2014 da Nota Técnica $\mathrm{n}^{\circ} 23$ da CGDH/Dpedhuc/Secadi/MEC, solicitada pela Secretaria de Direitos Humanos da 
Presidência da República (SDH) e o MDS, inaugura um esforço de articulação intersetorial visando à implementação do PNCFC e das Otsaca pelas Secretarias Municipais e Estaduais de Educação. O conteúdo das considerações iniciais do documento é uma explicação sobre o papel estruturante do PNCFC na política de atendimento a crianças e adolescentes, com vistas à garantia da convivência familiar e comunitária para esse público. Por outro lado, também aborda as Otsaca e sua importância para a Política de Assistência Social, no tocante à regulamentação e organização dos serviços de acolhimento, em sua articulação com outras políticas sociais, tais como a de Educação. Há toda uma explanação sobre os serviços de acolhimento em suas distintas modalidades, bem como uma menção ao papel da educação como política integrante da Rede de Atenção e Proteção dos Direitos Infantojuvenis, ressaltando a função da escolarização no processo educativo.

A análise técnica da nota menciona a Carta de Constituição de Estratégias em Defesa da Proteção Integral da Criança e do Adolescente ${ }^{67}$, a qual possui diretrizes e ações a serem executadas até 2015, prevendo a elaboração de orientações aos sistemas de ensino a fim de dar-lhes subsídio a respeito da escolarização de crianças e adolescentes em acolhimento. Informa ainda que a carta mobilizou a constituição de um grupo de trabalho formado por representantes do MEC, SDH e MDS, tendo sido municiados por dados do Censo Suas/2013, do Cadastro Nacional de Crianças e Adolescentes Acolhidos (CNCA), do Conselho Nacional de Justiça $(\mathrm{CNJ})$ e do Relatório de Inspeções do Ministério Público, sistematizado pelo Conselho Nacional do Ministério Público (CNMP).

Como primeira constatação da referida análise, as representações ministeriais perceberam "a necessidade de melhor quantificar e qualificar as informações sobre o nível de escolarização das crianças e adolescentes em situação de acolhimento", embora o documento indique que mesmo os dados preliminares ofereçam um importante diagnóstico sobre a escolarização do citado público. O diagnóstico aponta para os seguintes problemas: a) baixa escolaridade das crianças e adolescentes em acolhimento institucional; b) abandono escolar das crianças e adolescentes, com destaque para as faixas etárias mais avançadas; c) pouca interlocução entre as unidades de acolhimento e escola, além de uma falta de acompanhamento de seus responsáveis legais ao processo de escolarização; e d) a dificuldade de matrícula para as crianças e adolescentes a qualquer tempo, levando-se em conta as especificidades de um grupo que não ingressa nas escolas necessariamente no início do ano letivo, grupo esse que precisa, muitas vezes, transferir-se de escola pela adoção da medida

\footnotetext{
${ }^{67}$ A carta foi assinada em 2013 pelo sistema de Justiça e por órgãos do Poder Executivo federal.
} 
protetiva e pela reintegração ao lar. Observou-se também a ausência de um diagnóstico preciso sobre a escolaridade das crianças e adolescentes em acolhimento institucional e de um projeto pedagógico especificamente voltado para o referido público.

Com base nos dados apontados pelo diagnóstico preliminar, o MEC estabeleceu premissas para a garantia do direito à educação de crianças e adolescentes em acolhimento, além de parâmetros para ações no âmbito dos sistemas de ensino. Particularmente no tocante aos parâmetros, o MEC elenca várias sugestões para as Secretarias Municipais e Estaduais, entre elas:

a) A garantia de matrícula a qualquer tempo em qualquer nível, etapa e modalidade, adequada à faixa etária e idade escolar.

b) $\mathrm{O}$ alinhamento da escolarização das crianças e adolescentes com o Plano Individual de Atendimento (PIA), devendo a escola participar da sua construção.

c) A melhoria e/ou o estabelecimento de fluxos intersetoriais para acompanhamento da escolarização das crianças e adolescentes em situação de acolhimento, em especial com os órgãos da Assistência Social - Centro de Referência da Assistência Social (Cras), Centro de Referência Especializado da Assistência Social (Creas), órgão gestor da Política de Assistência Social do município, coordenação dos serviços de acolhimento, entre outros - e os Conselhos Tutelares.

d) A promoção de um acompanhamento dos coordenadores dos serviços de acolhimento ou das famílias acolhedoras na escolarização das crianças e adolescentes em situação de acolhimento.

e) A orientação para que as escolas elaborem o diagnóstico escolar das crianças e adolescentes em situação de acolhimento para fins de planejamento e acompanhamento pedagógico.

f) O fomento de uma interlocução permanente entre escola e acolhimento com o apoio das secretarias de educação, a fim de estabelecer uma proposta pedagógica e de procederem à escolha dos programas educacionais que considerem prioritários. Para tanto, o MEC elencou no documento: Mais Educação, Mais Cultura nas Escolas, Atletas na Escola, Ensino Médio Inovador, Programa Nacional de Acesso ao Ensino Técnico e Emprego, Projovem e Educação Inclusiva.

A nota técnica também aponta para a possibilidade da realização de cursos financiados pelo MEC (extensão, aperfeiçoamento ou especialização) para qualificação de profissionais da Educação que trabalham com o público infantojuvenil, em especial para aquele que vive 
em situação de vulnerabilidade. Cita, em particular, o programa Escola que Protege, voltado para a garantia de direitos de crianças e adolescentes, tendo a temática Convivência Familiar e Comunitária em sua ementa. A realização dos cursos é de responsabilidade das instituições públicas de ensino superior junto à Rede Nacional de Formação Continuada dos Profissionais de Educação Básica do Ministério da Educação (Renafor). A Secadi, no âmbito das responsabilidades do $\mathrm{MEC}$, então se coloca à disposição para prestar o apoio técnico às Secretarias Municipais e Estaduais de Educação naquilo que concerne ao estabelecimento de propostas e estratégias para o atendimento escolar de crianças e adolescentes acolhidos.

Podemos concluir, portanto, que a Nota Técnica $n^{\circ} 23$ aponta para uma convergência com os assuntos mencionados na pesquisa, dentre eles a necessidade de uma proposta pedagógica que contemple os acolhidos, a indicação da construção do PIA em ação conjunta com a escola e também a sugestão de que as profissionais do acolhimento acompanhem a escolarização das crianças e adolescentes. Entendemos que a nota representa um avanço, tendo em vista a histórica necessidade de que as Políticas de Assistência Social, Educação e Direitos Humanos se articulem em pontos que são problemáticos na esfera da escolarização básica, especialmente aquela que diz respeito às crianças e adolescentes em acolhimento, estando inclusive alinhada à Portaria ${ }^{\circ} 46$, que a antecedeu.

No entanto, as propostas que integram a nota esbarram na autonomia que as unidades federativas têm para implementá-las, uma vez que estão submetidas a seus planejamentos e às condições do financiamento para a execução das políticas sociais, conforme o quadro de correlação de forças estabelecido para o exercício de cada governo estadual e municipal. Há de se dizer que a intersetorialidade ${ }^{68}$, mesmo aquela cujo significado se atém somente à integração de "setores", também é bastante dificultada por uma longeva história de construção de políticas sociais de maneira desintegrada, tendo por motivação diferentes agentes, entre os quais a cultura e os interesses políticos das classes em disputa. Todavia, sem a integração das políticas, é impossível pensar em serviços públicos satisfatórios.

Todavia, a Nota Técnica $\mathrm{n}^{\mathrm{o}} 23$ somente pode funcionar como uma orientação coerente se as instituições de acolhimento funcionarem longe da precariedade em que se encontram,

\footnotetext{
${ }^{68}$ Pereira (2011b) apresenta um cuidadoso debate sobre a intersetorialidade e seu aspecto polissêmico, indicando que a mesma deve ser vista dialeticamente, pois a realidade em que as políticas públicas se inserem nunca é linear. A partir das poucas publicações disponíveis sobre intersetorialidade no Brasil, afirma que as "áreas da Educação e da Assistência Social têm produção pequena, embora a Assistência se apresente como intersetorial por princípio e por sua própria natureza dita transversal". Com isso fica claro que, apesar dos avanços sociais inscritos na Constituição Federal de 1988, prepondera a fragmentação da ação social estatal”. (PEREIRA, 2011b, p. 170).
} 
contratando pedagogos e outros técnicos que possibilitem ações interinstitucionais com as escolas, além de mantê-los tecnicamente capacitados às novas demandas da escolarização.

De acordo com o Conselho Federal de Serviço Social (CFESS), no ano de 2013:

Os recursos da seguridade foram destinados $74 \%$ para a Previdência Social, 15\% para a Saúde e $11 \%$ para a Assistência Social - considerando, neste percentual, o Benefício de Prestação Continuada (BPC), a Renda Mensal Vitalícia (RMV), Programas de Transferência de Renda - restando apenas $1,05 \%$ do orçamento para o cofinanciamento dos serviços, programas, projetos, política de educação permanente e os planos do Governo Federal (Brasil sem Miséria, Enfrentamento ao Crack e outras Drogas, Viver sem Limite).

Dados dessa monta ${ }^{69}$ colocam como bastante distantes os anseios por uma permanência escolar mais exitosa para os alunos. No tocante à Educação, o quadro não é alvissareiro também. Como relata a Nota Técnica ${ }^{\circ}$ 1/2013 da Associação Nacional de Pesquisa em Financiamento da Educação (Fineduca) ${ }^{70}$, a União historicamente participa com poucos recursos no financiamento das políticas públicas de Educação, inclusive na educação básica, o que é tema recorrente no federalismo brasileiro, obstando esse direito fundamental. A nota afirma que:

Segundo dados oficiais produzidos pelo Instituto Nacional de Estudos e Pesquisas Educacionais Anísio Teixeira (Inep) em 2009, último ano com informações disponíveis, a cada $\mathrm{R} \$ 1,00$ investido em educação pública, o Governo Federal contribui apenas com $\mathrm{R} \$ 0,20$, contra $\mathrm{R} \$ 0,41$ dos 26 estados e do Distrito Federal e R $\$ 0,39$ dos municípios. Ou seja, o ente federado que mais arrecada, possuidor de mais da metade da receita tributária líquida, é aquele que menos contribui com a Educação.

Entendemos que há uma agenda imensa por se concretizar no tocante à permanência escolar dos alunos em acolhimento institucional, que passa pelo financiamento das Políticas de Assistência Social e Educação. Passa também por maior instrumentalização dos sistemas de informação, tanto das pastas do Poder Executivo (MEC/MDS) quanto do Judiciário, a fim de que se obtenham dados mais precisos sobre esse público em especial. Considerando-se esses dados, a formação continuada teria mais possibilidades de sucesso. Pudemos ver, por exemplo, que no Distrito Federal, unidade federativa alinhada politicamente com o Governo Federal, não houve a oferta do curso de 2010 a 2014, conforme consulta à Renafor, o que significa uma perda para os profissionais de Educação que atuam com as crianças e com adolescentes em acolhimento. Ou seja, por múltiplos aspectos, podemos ver que há uma teia

\footnotetext{
${ }^{69}$ Disponível em: <www.cfess.org.br/arquivos/cfess_manifesta_20anosecaaprovado.pdf>.

${ }^{70}$ Trata-se de uma associação que busca congregar estudiosos na área de Financiamento da Educação, além de se propor a organizar e difundir informações referentes ao financiamento da Educação, entre outras propostas. Mais elementos sobre a nota técnica em: <www.redefinanciamento.ufpr.br/nota1_13.pdf>.
} 
de impedimentos políticos e econômicos vinculados aos setores hegemônicos da sociedade brasileira que afetam as políticas sociais de Educação e Assistência Social na prestação de serviços conforme a legislação.

Dessa forma, ratificamos a compreensão de que a permanência escolar com aprendizagem não é uma questão de mera boa vontade da escola e da unidade de acolhimento. 


\section{CONSIDERAÇÕES FINAIS}

A primeira e mais importante apreensão de nosso estudo, obtida por meio do exame das práticas escolares e de acolhimento, é que os estudantes acolhidos matriculados nos anos iniciais do ensino fundamental não vivenciam a evasão escolar, embora o direito à Educação se materialize por meio de uma permanência escolar complexa para eles. Vimos também ser confirmada a nossa hipótese de trabalho, uma vez que as escolas e as unidades de acolhimento não constroem ações conjuntas visando a garantir a permanência escolar de alunos acolhidos institucionalmente matriculados na rede pública de ensino. Entre elas há uma relação pontual, que se presta à resolução de problemas imediatos, de pequenos ajustes ou acertos quanto às demandas dos alunos acolhidos, inclusive casos de indisciplina. Não existe um planejamento conjunto entre elas para atividades de curto, médio e longo prazo.

Trata-se, dessa maneira, de uma permanência atravessada por problemas, ausências e insuficiências bastante diversos, tais como: a incipiente formação das profissionais da escola no tocante às questões de escolarização de estudantes acolhidos; a inexistência de PPPs escolares que atentem às particularidades das crianças em acolhimento com vistas à promoção de aprendizagem; a falta de fontes bibliográficas e outros recursos que proporcionem à escola entender com mais exatidão o acolhimento como medida protetiva; o desconhecimento das trajetórias individuais das crianças em acolhimento pela escola; a estigmatização sofrida por parte das crianças na escola; e a frequência escolar pouco proveitosa em termos de aprendizagem. Do ponto de vista das unidades de acolhimento, há a utilização de voluntários para o acompanhamento de tarefas escolares das crianças acolhidas, o que torna a atividade passível de não ser cumprida, uma vez que faltam bastante. Mesmo aquela unidade que contrata pedagogos para o direcionamento das atividades escolares, ao depender de voluntários, vê-se fragilizada em seus intentos de oferecer melhores condições de escolarização às crianças.

Os estudantes acolhidos, em particular, ainda não são pensados pelas unidades escolares como sujeitos de direitos, que requerem dos professores e da escola um conhecimento prévio a fim de que se proceda a mais adequada elaboração de seus planos de ensino e de aula. Sequer os PPPs escolares estão sintonizados com a realidade dessas crianças e suas demandas específicas, embora para isso haja também a necessidade de que as unidades 
de acolhimento partilhem mais informação sobre esses estudantes, questão que merece debates por todos aqueles que compõem o SGD, tendo em vista que o sigilo quase completo adotado pelas entidades em torno desses alunos, ao invés de protegê-los, muitas vezes opera para inviabilizar relações e expô-los a situações constrangedoras e evitáveis. Acreditamos que sua afirmação identitária deve ser buscada, portanto vemos como importante ponderar sobre a prática do silenciamento de suas histórias no decorrer do acolhimento, seja qual for a duração dele. Verificamos que as práticas no cotidiano das duas instituições (escolas e abrigos) estão permeadas por respostas individualizadas para problemas coletivos, o que despolitiza a situação em que vivem, situações que por vezes remetem ao ideário conservador das práticas pedagógicas da doutrina menorista, contemplado nos códigos de menores de 1927 e 1979, que tratavam as crianças e adolescentes de classes populares como entes tutelados, sem direitos a requerer, como meros receptores da caridade ou de ações residuais por parte do Estado. Essa contradição coloca-se muito claramente nas falas e práticas das professoras e gestoras das unidades escolares, apresentando-se como a negação do pressuposto da criança como sujeito de direitos prescrito no art. 227 da Constituição de 1988, do ECA de 1990 e dos planos e políticas relativos à Educação e à Assistência Social.

Outra constatação presente no estudo é que o mau desempenho escolar não é pensado a partir da precarização das relações de trabalho das professoras e das cuidadoras do abrigo, o que dificulta a resolução do problema com um trato pedagógico mais qualificado, com material bibliográfico específico e formação contínua. O insucesso é creditado ao desinteresse das crianças, aos reiterados problemas com a aprendizagem, à falta de acompanhamento pelo abrigo, dentre outros, o que as torna mais sujeitos de faltas do que de direitos.

Essas percepções do insucesso escolar acabam por minar o investimento na capacidade dos sujeitos infantojuvenis acolhidos de participarem da vida escolar com o uso de suas capacidades cognitivas, afetivas e criativas, em semelhantes condições de aprendizagem de outros alunos, por meio da utilização de aparato científico para conduzir o ensino. Isto quer dizer que é possível, mesmo frente a algumas limitações internas reveladas nas práticas institucionais, haver por parte da criança uma resposta satisfatória às demandas escolares, desde que haja um direcionamento pedagógico que propicie a aprendizagem. Na contramão disso, a escola vem creditando o fracasso escolar inclusive ao histórico de vida familiar dos alunos ou às suas características emocionais ou psicológicas, sem ao menos ter uma compreensão mais aprofundada da trajetória de cada criança acolhida, situação proporcionada 
também por um diálogo superficial entre abrigos e escolas em relação ao histórico desses alunos, minimizando o papel educativo de ambas as instituições.

Nesse cenário, as respostas às problemáticas da permanência escolar para crianças e adolescentes em situação de medidas protetivas de acolhimento são construídas, não raras vezes, sob a égide de práticas educativas baseadas em concepções individualizantes, moralistas e repressivas. Isso torna evidente, por um lado, a hegemonia do pensamento funcional positivo em detrimento de ações pedagógicas que busquem fortalecer a garantia dos direitos deste segmento, proporcionando que a permanência escolar qualifique a criança a enfrentar as injustiças de hoje e de amanhã provocadas pela sua condição de classe, de institucionalização, de raça, gênero, etnia, territorialidade, diversidade sexual, etc. Também é contraditório exigir práticas institucionais compatíveis com um sujeito de direitos em instituições que reproduzem simultaneamente o ideário liberal (onde compete ao sujeito o alcance do sucesso) e o conservador (que atribui à família a condição moral do indivíduo e às instituições a responsabilidade de formar indivíduos cordatos, colaboradores e passivos frente à ordem hegemônica).

Somam-se aos problemas já expostos a dificuldade em garantir a proteção da criança (e do adolescente), naquilo que concerne à Assistência Social e à Educação, em uma conjuntura de desmonte do Estado de Direito constitucional, em função da ofensiva neoliberal, que podemos também denominar "contrarreforma". Ficou evidente, no decorrer da pesquisa, que ainda não há um entendimento de que os serviços de acolhimento de crianças e adolescentes sejam espaços educativos, que devam se guiar por uma concepção de educação. O texto das Otsaca, embora contemple cuidados referentes ao respeito e à dignidade de crianças e adolescentes, alertando contra a discriminação em diferentes âmbitos (racial, de orientação sexual, de origem, entre outras preocupações), não apresenta enfaticamente o serviço de acolhimento institucional como um espaço ao mesmo tempo protetivo e educativo, expectativa trivial, tendo em vista que se trata de um local que recebe pessoas em desenvolvimento, o que, de alguma forma, esmaece um debate mais consistente sobre o ideário de educação que deve dar suporte ao fazer cotidiano da unidade de acolhimento em suas tarefas com as crianças, sejam escolares ou aquelas que lhes extrapolem. Pensar o acolhimento desengajado de uma concepção de educação é tão preocupante quanto pensar a escolarização desengajada do sentido de proteção.

Ao mesmo tempo, observamos que os esforços por um trato intersetorial (entre Educação e Assistência Social) da escolarização de estudantes acolhidos, nos governos 
distrital e federal, no âmbito de suas competências, são bastante embrionários, não propiciando sequer um adequado monitoramento daquilo que vem sendo realizado junto aos estudantes acolhidos em termos de sua escolarização, sem deixar de mencionar que o subfinanciamento que acomete as Políticas de Assistência Social e Educação compromete significativamente pretensões por serviços de qualidade, dentro da conformidade constitucional e de outros instrumentos legais.

Nessa perspectiva, entendemos que essas contradições apontadas também constituem sua própria negação. Isto é, ao explicitarmos as armadilhas contidas na relação escola-unidade de acolhimento, podemos potencializar a superação dessas contradições. Queremos dizer que se faz necessário construir estratégias dentro dessas realidades socioinstitucionais, sobretudo para que se eleve a capacidade de mobilização e participação do conjunto dos trabalhadores dessas políticas e dos seus usuários para tomada de consciência e defesa da política social pública, propiciando assim a retomada de conquistas constitucionais severamente minadas pelos ajustes neoliberais, que transformam direitos sociais em mercadorias, fazendo da escola pública um espaço de uma educação acrítica e da Assistência Social um serviço desvinculado do sentido de justiça.

Nada do que apreendemos em nosso fazer investigativo está em desacordo com o que se verifica no plano das leis tendenciais históricas (ou universalidades), que se perpetuam sob diferentes circunstâncias ao longo dos séculos nas sociedades capitalistas, legalidades que permitem a existência, em nossos dias, de um ataque à educação como direito subjetivo, quais sejam: país de economia dependente, políticas sociais guiadas por interesses e organismos internacionais, a subjugação das políticas sociais aos interesses econômicos estranhos à classe trabalhadora, o ingresso de mecanismos de mercado nas políticas públicas, entre tantos outros fatores.

Nesse campo de universalidades (PONTES, 1996) aparecem ainda o racismo e o patriarcado, produzindo efeitos articulados ao capitalismo, tendo um forte rebatimento em particular na vida das mães pobres e não brancas, que possuem a mesma composição sociorracial da maioria das crianças em acolhimento, que, como está disposto em pesquisas, não é branca (58\%).

A particularidade (PONTES, 1996) é um campo de mediações em que demandas institucionais e demandas sociais vêm se rebater. É nesse campo, então, que se colocam as correlações de forças entre as classes, as políticas sociais dentro das instituições, a rede de proteção social, a relação entre indivíduo e sociedade e o próprio processo socioprodutivo, 
aspectos em que nos detivemos durante toda a pesquisa a fim de conhecer melhor aquilo a que nos propomos, escapando de uma análise baseada em dados imediatos, que retiram dos problemas suas determinações históricas e ideológicas. Todo esse caminho permitiu pensar em novas intervenções em favor dos escolares, das profissionais da educação e das profissionais do acolhimento e dos serviços por elas prestados. Isso porque, ainda que tenhamos presenciado situações em que a escola buscou proteger as crianças, proporcionando situações de aprendizagem - e por outro lado observado a unidade de acolhimento se munir de esforços para que as crianças acessassem o ensino fundamental, ambas em conformidade com o ECA -, observamos com grande frequência o aparecimento de entraves substantivos, tal como foi exposto.

As práticas institucionais apontaram, em desacordo com as aspirações por uma Educação e por uma Assistência Social firmemente comprometidas com seus usuários, para episódios de desresponsabilização da escola e do abrigo em relação ao caráter da permanência escolar das crianças em medidas protetivas. Isso ocorre na medida em que a escola atribui a terceiros a maior reponsabilidade pelo sucesso escolar: para a família da criança que sequer está presente em sua vida de maneira efetiva, ou ainda para profissionais do acolhimento. As profissionais do acolhimento, por sua vez, fazem o mesmo quando repassam parte das responsabilidades para voluntários, ainda que tenham técnicos em Educação em seus quadros.

Por outro lado, é preciso considerar que a escola, que tem como função social específica socializar o conhecimento acumulado pela humanidade, tem suas potencialidades minoradas em um cenário neoliberal, enquanto as famílias ou suas substitutas veem crescer, sem recursos disponíveis para tanto, suas obrigações na formação escolarizada da criança.

E não se trata de afirmar que a escola esteja sem tarefas para executar, mas de pensar a real possibilidade de ela vir a socializar conhecimentos acumulados, de ensinar a todos, em contextos adversos como os que estão colocados para esta etapa da modernidade, em um país de economia capitalista dependente como o Brasil. O cenário de precariedades em que ela está inserida, a despolitização em que se vê envolvida (mesmo com a organização sindical de seus trabalhadores) e as novas demandas que surgiram após o advento da CF/1988, da LDB em vigência e particularmente das avaliações institucionais em âmbitos federal e local trouxeram novas incumbências para professoras e gestoras. Elas não esgotam no ensino e em seu planejamento as suas atividades profissionais. A recorrência da escola às famílias não pode ser vista como simples descompromisso com o aluno, mas um testemunho de sua fragilidade 
material e ideológica para construir uma relação pedagógica com os alunos, tecida em pormenores, com direcionamento e com propósito bem definido e articulado. Pensar a ação e a relação pedagógica é fundamental, uma vez que quaisquer práticas educativas consequentes não podem se realizar desvinculadas dos contextos políticos, econômicos, sociais e culturais sob os quais a vida em sociedade está erguida.

A aspiração de professoras e de gestoras escolares por um trabalho pedagógico de qualidade, cumprindo seu papel mediador, esbarra em impedimentos que são estruturais, mas que podem ser questionados e minimamente dissipados por ações e movimentos coletivos, mesmo dentro do capitalismo. A intervenção para a melhoria do quadro evidenciado na pesquisa passa então pela mobilização de todos aqueles que acreditam na escolarização como elemento importante na construção da autonomia e criticidade dessas crianças. É preciso situar o esmaecimento do Estado como uma realidade que tem cruel repercussão nas unidades de acolhimento e nas unidades escolares, desnaturalizando a espera de voluntários e parcerias pela primeira instituição e politizando a presença de crianças acolhidas como um dado da questão social pela segunda.

É fato que as Políticas Sociais Públicas lentamente deixam de ser vistas como responsabilidade estatal, para que mais violações aos direitos educacionais não se repitam. Alencar (2009), mais detalhadamente, comenta:

Vem-se operando a despolitização das demandas sociais, ao mesmo tempo em que desresponsabiliza o Estado e responsabiliza os sujeitos sociais pelas respostas às suas necessidades. [...] Nesse contexto, observa-se um profundo deslocamento quanto aos direitos sociais agora transmutados em "direito moral", sob os princípios abstratos da "ajuda mútua" e "solidariedade". (ALENCAR, 2009, p. 455-456).

Assim, é preciso direcionar as lutas da classe trabalhadora para que a escola e a unidade de acolhimento sejam fortalecidas em sua capacidade de ofertar os serviços que socialmente lhes cabem, sem o depósito de expectativas nas famílias dos alunos, nas parcerias e no voluntariado, os quais representam o esvaziamento do papel do Estado.

No contexto em que nos encontramos, as escolas e os abrigos, como espaços de mediação, têm funções contraditórias (proteção x tutela) e exatamente por isso é preciso construir para ambos as possibilidades de superação deste quadro.

Durante a formatura de uma turma de graduação, Saviani (1985) pronunciou um importante discurso, do qual apresentamos um excerto: 
Empenhem-se no domínio das formas que possam garantir às camadas populares o ingresso na cultura letrada, vale dizer, a apropriação dos conhecimentos sistematizados. E, no interior das escolas, lembrem-se sempre de que o papel próprio de vocês será provê-las de uma organização tal que cada criança, cada educando, em especial aquele das camadas trabalhadoras, não veja frustrada a sua aspiração de assimilar os conhecimentos metódicos, incorporando-os como instrumento irreversível a partir do qual será possível conferir uma nova qualidade às suas lutas no seio da sociedade. A vocês cabe, pois, velar no interior das escolas para que elas não se percam num sem-número de atividades acessórias, desviando-se de seu papel fundamental, que é a difusão do saber sistematizado [...]. (SAVIANI, 1985, p. 28).

Em que pesem todos os contextos adversos para as crianças das classes trabalhadoras estudarem, o autor não descartou o papel político dos professores em construir agendas que não minimizem os conteúdos em nome de uma escola com função meramente acolhedora. O papel daqueles que atuam na Assistência Social caminha no mesmo propósito de resistência.

Como assinala a Carta de Maceió, elaborada no $29^{\circ}$ Encontro Nacional do Conjunto CFESS/CRESS, a Seguridade Social deve ser entendida como:

Um terreno de embate que requer competência teórica, política e técnica. Que exige uma rigorosa análise crítica da correlação de forças entre classes e segmentos de classe, que interferem nas decisões em cada conjuntura. Que força a construção de proposições que se contraponham às reações das elites políticas e econômicas do país, difusoras de uma responsabilização dos pobres pela sua condição, ideologia que expressa uma verdadeira indisposição de abrir mão de suas taxas de lucro, de juros, de sua renda da terra. (CFESS, 2000, p. 31).

Por último, acreditamos que, embora tenhamos tratado de escolas e unidades de acolhimento situadas no Distrito Federal, nossa preocupação se estende pelas demais escolas que matriculam crianças acolhidas em todo o Brasil. A partir das dificuldades que sentimos de identificar as unidades de ensino que possuem alunos em acolhimento, de detectar sua trajetória de escolarização e de a SEDF e Sedest fazerem intersetorialmente um monitoramento da vida escolar de todos os alunos sob essa medida de proteção, consideramos fundamental a articulação de todo o SGD no sentido de construir um sistema de informações que torne democrático o acesso aos resultados sobre o andamento escolar desse público, sem deixar de respeitar as confidencialidades que se fizerem necessárias. Essa medida oferecerá as condições para que se avalie nacionalmente tudo aquilo que ainda há por fazer para que o acolhimento institucional não seja relacionado somente ao insucesso escolar, pois, como dissemos, nas contradições podemos enxergar caminhos de luta. 


\section{REFERENCIAS}

ABOITES, Hugo. El derecho a la educación en México: del liberalismo decimonónico al neoliberalismo del siglo XXI. Revista Mexicana de Investigación Educativa, v. 17, n. 53, 2012. Disponível em: <www.scielo.org.mx/pdf/rmie/v17n53/v17n53a3.pdf>. Acesso em: 12 mar. 2014.

AFONSO, Almerindo. Avaliação educacional: regulação e emancipação para uma sociologia das políticas contemporâneas. 3. ed. São Paulo: Cortez, 2005.

AGUIAR, W. M. J. Armadilhas e alternativas nos processos educacionais e na formação de professores: uma análise na perspectivada psicologia sócio-histórica. In: JACÓ-VILELA, Ana Maria; SATO, L. (Org.). Diálogos em psicologia social. Rio de Janeiro: Centro Edelstein de Pesquisas Sociais, 2012. p. 58-70.

AGUILAR FILHO, Sidney. Educação, autoritarismo e eugenia: exploração do trabalho e violência à infância no Brasil (1930-45). 2011. 357 f. Tese (Doutorado)-Faculdade de Educação, Universidade Estadual de Campinas, Campinas, 2011.

ALENCAR, Mônica. O trabalho do assistente social nas organizações privadas não lucrativas. In: Serviço Social: direitos sociais e competências profissionais. Brasília: CFESS/ABEPSS, 2009.

ALGEBAILE, Eveline. Escola pública e pobreza no Brasil: a ampliação para menos. Rio de Janeiro: Lamparina, Faperj, 2009.

ANDRADE, O. A saúde e o dilema da intersetorialidade. São Paulo: Hucitec, 2006.

ARIÈS, Philippe. História social da infância e da família. Tradução D. Flaksman. Rio de Janeiro: LCT, 1978.

ASSIS, Samuel G; YANNOULAS, Silvia C. A pobreza na formação docente: a situação de pobreza na formação das futuras professoras. Educação Unisinos (Online), v. 16, p. 251/07-261, 2012.

ASSIS, Simone et al. (Org.). Teoria e prática dos conselhos tutelares e conselhos dos direitos da criança e do adolescente. Rio de Janeiro: Editora Fiocruz/EAD-ENSP, 2009. $292 \mathrm{p}$.

ASSIS, Simone; FARIAS, Luis Otávio. (Org.). Levantamento nacional das crianças e adolescentes em serviços de acolhimento. São Paulo: HUCITEC, 2013.

BAPTISTA, Myrian Veras. Algumas reflexões sobre o sistema de garantia de direitos. Revista Serviço Social e Sociedade, São Paulo, n. 109, p. 179-199, 2012. 
BATISTA, Eraldo L.; LIMA, Marcos R. A pedagogia histórico-crítica como teoria pedagógica transformadora: da consciência filosófica a prática revolucionária. In: Pedagogia histórico-crítica: desafios e perspectivas para uma prática transformadora. Campinas: Autores Associados, 2012.

BARDIN, Laurence. Análise de conteúdo. Lisboa, Portugal: Edições 70, LDA, 2009.

BEHRING, Elaine Rossetti. Brasil em Contra-reforma: desestruturação do Estado e perda de direitos. São Paulo: Cortez, 2003.

BEHRING, Elaine R.; SANTOS, S. Questão social e direitos. In: Serviço social: direitos sociais e competências profissionais. Brasília: CFESS/ABEPSS, 2009, p. 267-283.

BEHRING, Elaine R.; BOSCHETTI, Ivanete. Política social: fundamentos e história. 7. ed., v. 1. São Paulo: Cortez, 2006.

BERNARDES, Maria Elisa. A educação como mediação na teoria histórico-cultural: compromissos ético e político no processo de emancipação humana. Psicologia Política, São Paulo, v. 10, n. 20, dez. 2010.

BIRMAN, Joel. Tatuando o desamparo: a juventude na atualidade. In: CARDOSO, M. R. (Org.). Adolescentes. São Paulo: Escuta, 2006.

BISPO, Alessandra B. A cultura escolar na cidade de menores "Getúlio Vargas". In: V ENCONTRO NORDESTINO DE HISTÓRIA, 5. e ENCONTRO ESTADUAL DE HISTÓRIA, 5. Anais... Recife: UFPE, 2004.

BOARINI, Maria Lucia. Indisciplina escolar: uma construção coletiva. Psicologia Escolar e Educacional, Maringá, v. 17, n. 1, jun. 2013. Disponível em: $<w w w . s c i e l o . b r / s c i e l o . p h p ? s c r i p t=s c i \_a r t t e x t \& p i d=S 1413-85572013000100013>$. Acesso em: 23 jul. 2014.

BOCK, Ana Maria; GONÇALVES, M.G.M. Subjetividade: o sujeito e a dimensão subjetiva dos fatos. In: GONZÁLEZ-REY, F (Org.) Subjetividade, complexidade e pesquisa em psicologia. São Paulo: Thomson, 2005.

BOSCHETTI, Ivanete. Implicações da reforma da previdência na seguridade social brasileira. Psicologia Social, v. 15, n. 1, p. 57-96, 2003. Disponível em: $<$ www.scielo.br/scielo.php?pid=S0102-71822003000100005\&script=sci_arttext $>$. Acesso em: 4 set. 2014.

BOSCHETTI, Ivanete; TEIXEIRA, Sandra Oliveira. Seletividade e focalização da política de assistência social no Brasil. Surá, San José, n. 88, nov. 2013. Disponível em: <www.ts.ucr.ac.cr/binarios/congresos/reg/slets/slets-018-081.pdf>. Acesso em: 17 dez. 2013.

BOURDIEU, Pierre. Escritos de educação. 14. ed. Petrópolis: Vozes, 1999.

BOURDIEU, Pierre; PASSERÓN, Jean Claude. A reprodução: elementos para uma teoria do sistema de ensino. Rio de Janeiro: Francisco Alves, 1975. 
BRASIL. Código de Menores. Lei nº 6.697, de 1979.

. Convenção sobre os Direitos da Criança. Decreto n 99.710, de 21 nov. 1990.

Brasília: Senado Federal, 1990.

. Constituição da República Federativa do Brasil. Brasília: Senado, 1988.

Estatuto da Criança e do Adolescente. Lei Federal nº 8.069, de 13 jul. 1990a.

Ministério da Educação. Ensino fundamental de nove anos: passo a passo do processo de implantação. 2. ed. Brasília: Ministério da Educação, set. 2009.

Lei de Diretrizes e Bases da Educação Nacional. Lei n 9.394, de 20 dez. 1996.

. Lei Orgânica de Assistência Social. Lei no 8.742, de 7 dez. 1993.

. Ministério da Educação. Ensino Fundamental de nove anos: orientações para a inclusão da criança de seis anos de idade. Brasília: FNDE, Estação Gráfica, 2007.

Plano Nacional de Promoção, Proteção e Defesa do Direito de Crianças e Adolescentes à Convivência Familiar e Comunitária. 2007.

. Política Nacional de Assistência Social - PNAS/2004. Ministério do Desenvolvimento Social e Combate à Fome. Secretaria Nacional de Assistência Social. Brasília: nov. 2005.

BUFFA, E.; BAUER, C.; FILONOV, G. N. (Org.) Anton Makarenko. Recife: Fundação Joaquim Nabuco, 2010. 136 p.

CAMPOS, Herculano Ricardo; JORGE, Samia. Violência na escola: uma reflexão sobre o bullying e a prática educativa. Em Aberto, Brasília, v. 23, n. 83, p. 107-128, mar. 2010.

CARDOSO, Miriam. Sobre as relações sociais capitalistas. In: LIMA, J. C. F; NEVES, W. L. (Org.) Fundamentos da Educação escolar do Brasil contemporâneo. Rio de Janeiro: Fiocruz, 2006. p. 25-68.

CARMO, Gerson Tavares do et al. Alunos jovens e adultos de Itaperuna: quem mais contribui para que permaneçam na escola. In: Mostra de Extensão IFF-UENF-UFF, 4. Campos dos Goytacazes: 2012. 1 CD-ROM.

CARNOY, Martin. Estado e teoria política. Tradução equipe de trad. PUCCAMP. 15. ed. Campinas: Papirus, 2010.

CARVALHO, Maria Eulina Pessoa de. Escola como extensão da família ou família como extensão da escola? O dever de casa e as relações família-escola. Revista Brasileira de Educação, n. 25, p. 94-104, 2004. Disponível em: <www.scielo.br/pdf/rbedu/n25/n25a08.pdf>. Acesso em: 21 jul. 2014.

CASTELO, Rodrigo. Serviço Social e Sociedade. São Paulo, n. 112, p. 613-636, out./dez. 2012. 
CHIRINÉA, Andréia Melanda. O Índice de Desenvolvimento da Educação Básica (IDEB) e as dimensões associadas à qualidade da educação na escola pública municipal. Marília, 2010. 121 f. Dissertação (Mestrado em Educação)-Faculdade de Filosofia e Ciências, Universidade Estadual Paulista, São Paulo, 2010.

CHRISPINO, Álvaro; CHRISPINO, Raquel S. P. A judicialização das relações escolares e a responsabilidade civil dos educadores. Ensaio: avaliação e políticas públicas em Educação, Rio de Janeiro, v. 16, n. 58, p. 9-30, jan./mar. 2008. Disponível em: <www.scielo.br/pdf/ensaio/v16n58/a02v1658.pdf>. Acesso em: 28 jul. 2014.

CONANDA/CNAS. Orientações Técnicas: Serviços de Acolhimento para Crianças e Adolescentes. Brasília-DF, 2009.

CONSELHO FEDERAL DE PSICOLOGIA. Subsídios para a Campanha "Não à Medicalização da Vida". Gestão 2011-2013. Disponível em: <http://site.cfp.org.br/wpcontent/uploads/2012/07/Caderno_AF.pdf>. Acesso em: 19 out. 2014.

CONSELHO FEDERAL DE SERVIÇO SOCIAL. Subsídios para a atuação de assistentes sociais na política de educação. 2012. Disponível em: $<$ www.cfess.org.br/arquivos/BROCHURACFESS_SUBSIDIOS-AS-EDUCACAO.pdf>. Acesso em: 30 ago. 2014.

20 Anos do estatuto da Criança e do Adolescente. CFESS Manifesta, Brasília, 13 jul. 2010. Disponível em: <www.cfess.org.br/arquivos/cfess_manifesta_20anosecaaprovado.pdf>. Acesso em: 15 out. 2014.

Carta de Maceió: Seguridade Social Pública é possível! XXIX In: ENCONTRO NACIONAL CFESS/CRESS, 29, 2000. Relatório de Deliberações. Alagoas: CFESS, 2000.

COSTA, Antônio Carlos Gomes (Org.). O mundo, o trabalho e você. São Paulo: Instituto Ayrton Senna, 2002.

COUTINHO, Carlos Nelson. O Estado brasileiro: gênese, crise, alternativas. In. LIMA, J. C. F.; NEVES, W. L. (Org.) Fundamentos da educação escolar do Brasil contemporâneo. Rio de Janeiro: Fiocruz, 2006. p. 173-201.

DELL'AGLIO, Débora Dalbosco; HUTZ, Cláudio Simon. Depressão e desempenho escolar em crianças e adolescentes institucionalizados. Psicologia: Reflexão e Crítica, v. 17, n. 3, p. 341-350, 2004. Disponível em: <www.scielo.br/pdf/prc/v17n3/a08v17n3.pdf>. Acesso em: 17 set. 2014.

DESLANDES, S. F. A construção do projeto de pesquisa. In: MARIA CECÍLIA DE SOUZA MINAYO. (Org.). Teoria, método e criatividade: introdução à pesquisa social, v. 1. 18. ed. Petrópolis: Vozes, 1994.

DISTRITO FEDERAL (Brasil). Diretrizes de avaliação educacional. 2014-2016. Disponível em: <www.cre.se.df.gov.br/ascom/documentos/diretrizes_avaliação_educacional.pdf>. Acesso em: 20 ago. 2014. 
Secretaria de Estado de Educação. Diretrizes Pedagógicas do Bloco Inicial de Alfabetização. 2. ed. Brasília: GDF, 2012.

Secretaria de Estado de Educação. Regimento Escolar das Instituições Educacionais da Rede Pública de Ensino do Distrito Federal. 5. ed. Brasília: GDF, 2009. $90 \mathrm{p}$.

DOURADO, Luiz Fernandes; OLIVEIRA, João Ferreira de. A qualidade da educação: perspectivas e desafios. Cadernos CEDES, Campinas, v. 29, n. 78, ago. 2009. Disponível em: $<w w w . s c i e l o . b r / s c i e l o . p h p ?$ script=sci_arttext\&pid=S0101-32622009000200004 $>$. Acesso em: 31 out. 2014.

DUARTE, Natália de Souza. Política Social: Um estudo sobre educação e pobreza. Tese apresentada ao PPG em Política Social da Universidade de Brasília. 2012.

O impacto da pobreza no Ideb: um estudo multinível. Revista Brasileira de

Estudos Pedagógicos, Brasília, v. 94, n. 237, ago. 2013. Disponível em: $<$ www.scielo.br/scielo.php?script=sci_arttext\&pid=S2176-66812013000200002>. Acesso em: 31 ago. 2014.

DUARTE, Newton. A individualidade para - si: contribuição a uma teoria histórico-social da formação do indivíduo. Campinas: Editores Associados, 2013.

Fundamentos da pedagogia histórico-crítica: a formação do ser humano na sociedade comunista como referência para a educação contemporânea. 2009. Disponível em:

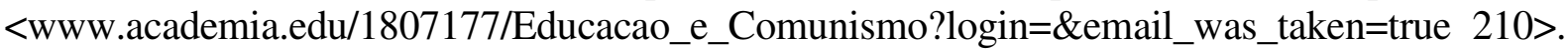
Acesso em: 29 ago. 2014.

. Educação escolar, teoria do cotidiano e a escola de Vigotski. 4. ed. Campinas: Autores Associados, 2007.

(Org.). Crítica ao fetichismo da individualidade. 2. ed. Campinas: Autores Associados, 2012. 223 p.

347 p.

Vigotski e o "Aprender a Aprender”. 5. ed. Campinas: Autores Associados, 2012.

ELKONIN, Daniil. Psicologia do jogo. São Paulo: Martins Fontes, 1998.

ENGELS, Friederich. A origem da família, da propriedade privada e do Estado. 4. ed. São Paulo: Global, 1984. 236 p.

ESPING-ANDERSEN, Gosta. As três economias políticas no Welfare State. Lua Nova, n. 24, p. 85-116, 1991.

FACCI, Marilda. A periodização do desenvolvimento psicológico individual na perspectiva de Leontiev, Elkonin e Vigotski. Cadernos Cedes, Campinas, v. 24, n. 62, p. 64-81, abr. 2004. 
FALEIROS, V. P.; FALEIROS, Eva T. Silveira. Escola que protege: enfrentando a violência contra crianças e adolescentes. Brasília: Ministério da Educação, 2007. 100 p.

FERNANDES, Florestan. A revolução burguesa no Brasil: Ensaios de interpretação sociológica. Rio de Janeiro: Zahar, 1975.

Nova República? Rio de Janeiro: Zahar, 1985.

Idília. A dialética das possibilidades: a face interventiva do Serviço Social. Textos \&

Contextos, n. 4, dez. 2005.

FERREIRA, Thaiane. A atuação do orientador educacional escolar no Distrito Federal: Limites e Possibilidades. 2013. Dissertação (Mestrado em Educação)-Universidade de Brasília.

FLACH, S. F. Direito à educação e obrigatoriedade escolar no Brasil: entre a previsão legal e a realidade. Revista HISTEDBR Online, v. 43, p. 285-303, 2011.

FONSECA, Mendes Dirce et al. Escola, conflitualidade e violência. Universitas Humanas, Brasília, v. 7, p. 55-80, 2010.

O discurso de proteção e as políticas sociais para a infância e a juventude. Revista Jurídica, Brasília, v. 9, p. 73-82, 2007.

FRANCISCO, Marcos Vinicius. A construção social da personalidade de adolescentes expostos ao bullying escolar e os processos de "resiliência em-si": uma análise históricocultural. 2013. 266 f. Tese (Doutorado em Educação)-Universidade Estadual Paulista, Faculdade de Ciências e Tecnologia, 2013.

FRANCISCO, M. V.; LIBÓRIO, R. M. C. Reflexões sobre a superação de concepções individualizantes sobre o bullying escolar. In: RIBEIRO, A. I. M. et al. Educação contemporânea: caminhos, obstáculos e travessias. São Paulo: Cultura Acadêmica, 2011. p. 61-78.

Análise do bullying escolar a partir da Teoria Histórico-Cultural: crítica a sua concepção neoliberal. In: CONGRESSO INTERNACIONAL SOBRE A TEORIA HISTÓRICO-CULTURAL, 1., e JORNADA DO NÚCLEO DE ENSINO DE MARÍLIA, 11. 2012a, Marília. Anais... Marília: Unesp, 2012a. p. 1-10.

FRANCO, Maria Laura P. B. Análise do Conteúdo. Série Pesquisa em Educação. Brasília: Plano, 2003.

FREIRE, Paulo. A sombra desta mangueira. São Paulo: Olho d’Água, 1995.

Pedagogia da indignação: cartas pedagógicas e outros escritos. Apresentação de Ana Maria Araújo Freire. Carta-prefácio de Balduíno A. Andreola. São Paulo: Unesp, 2000.

FREYRE, Gilberto. Casa-grande \& Senzala: formação da família brasileira sob o regime da economia patriarcal. 49. ed. São Paulo: Global, 2004. 
FREITAS, Lorena. A instituição do fracasso: a educação da ralé. In: SOUZA, Jessé (Org.). A ralé brasileira: quem é e como vive. Belo Horizonte: UFMG, 2009.

FRIGOTTO, Gaudêncio e CIAVATTA, Maria. Educação Básica no Brasil na década de 1990: Subordinação ativa e consentida à lógica do mercado. Educ. Soc., Campinas, v. 24, n. 82, p. 93-130, abr. 2003.

GARCIA, Maria Manuela Alves; ANADON, Simone Barreto. Reforma educacional, intensificação e autointensificação do trabalho docente. Educ. Soc. (online), v. 30, n. 106, p. 63-85, 2009. ISSN 0101-7330.

GASPARIN, João Luiz. Uma didática para a pedagogia histórico-crítica. Campinas: Autores Associados, 2002.

GHIRALDELLI JÚNIOR, Paulo. História da educação. 2. ed. São Paulo: Cortez, 1990.

História da educação brasileira. São Paulo: Cortez, 2006.

GOHN, Maria da Glória. Empoderamento e participação da comunidade em políticas sociais. Saúde e Sociedade, v. 13, n. 2, p. 20-31, 2004. Disponível em: $<$ www.scielo.br/scielo.php?pid=S0104-12902004000200003\&script=sci_arttext $>$. Acesso em: 28 set. 2014.

GRAMSCI, A. Cadernos do cárcere. v. 2. Os intelectuais; o princípio educativo; jornalismo. Rio de Janeiro: Civilização Brasileira, 2004.

HENRIQUES, Ricardo; FIALHO, Leandro; CHAMUSCA, Adelaide (Org.). Proteger para Educar: a escola articulada com as redes de proteção de crianças e adolescentes. Disponível em: <http://portal.mec.gov.br/secad/arquivos/pdf/escola_protege/cad_escolaqprotege.pdf>. Acesso em: 2 ago. 2014.

IAMAMOTO, Marilda Villela. O serviço social em tempo de capital fetiche: capital financeiro, trabalho e questão social. 3. ed. São Paulo: Cortez, 2007.

; CARVALHO, Raul de. Relações sociais e serviço social no Brasil: esboço de uma interpretação histórico-metodológica. 29. ed. São Paulo/Lima: Cortez/CELATS, 2009. 384 p.

JANCZURA, Rosane. Abrigos e políticas públicas: as contradições na efetivação dos direitos da criança e do adolescente. Porto Alegre, 2008. $273 \mathrm{f}$. Tese (Doutorado em Serviço Social)-Pontifícia Universidade Católica - RS, 2008.

JOU, Graciela Inchausti de et al. Transtorno de déficit de atenção e hiperatividade: um olhar no ensino fundamental. Psicologia: Reflexão e Crítica, Porto Alegre, v. 23, n. 1, abr. 2010. Disponível em: <www.scielo.br/scielo.php?script=sci_arttext\&pid=S0102-79722010000100005>. Acesso em: 16 nov. 2014.

LAHIRE, Bernard. Sucesso escolar nos meios populares: as razões do improvável. São. Paulo: Ática, 1997. Tradução. 
LAJÚS, Maria Luiza. Sistema único de assistência social: um difícil caminho rumo à conquista da cidadania. Porto Alegre, 2010. 294 f. Tese (Doutorado)-Pontifícia Universidade Católica do Rio Grande do Sul, Porto Alegre, 2008.

LEAL, Maria Lúcia. Violência intrafamiliar: um estudo preliminar. In: LEAL, Maria de Fátima; CÉSAR, Maria Auxiliadora (Org.). Indicadores de violência intrafamiliar e exploração sexual comercial de crianças e adolescentes. Brasília: CESE, MJ/SNDH/DCA, CECRIA, 1997.

LEHER, Roberto. Educação no capitalismo dependente ou exclusão educacional? In: MENDONÇA, Sueli Guadalupe de Lima; SILVA, Vandei Pinto da; MILLER, Stela. Marx, Gramsci e Vigotski: aproximações. 2. ed. Araraquara: Junqueira \& Marrin, 2012.

LEMOS, Denise. Trabalho Docente: Alienação Ou Emancipação? SEMINÁRIO DA REDESTRADO - REGULAÇÃO EDUCACIONAL E TRABALHO DOCENTE, 6, 2006, Rio de Janeiro. Anais... Rio de Janeiro: UERJ, 2006. Disponível em: <www.fae.ufmg.br/estrado/cd_viseminario/trabalhos/eixo_tematico_1/trabalho_docente_alienacao.pdf $>$. Acesso em: 15 jul. 2014.

LENSKIJ, Tatiana. Direito à permanência na escola: a lei, as políticas públicas e as práticas escolares. 2006. 175 f. Dissertação (Mestrado em Educação)-Universidade Federal do Rio Grande do Sul, Porto Alegre, 2006.

LEONTIEV, Alexei Nikolaevich. Uma contribuição à teoria do desenvolvimento da psique infantil. In: LEONTIEV, Alexei Nikolaevich, VYGOTSKY, Lev Semenovich; LURIA, Alexander Romanovich. Linguagem, desenvolvimento e aprendizagem. São Paulo: Ícone, 1994. p. 59-83.

O desenvolvimento do psiquismo. Lisboa: Livros Horizonte, 1978.

LIBÂNEO, José C. O dualismo perverso da escola pública brasileira: escola do conhecimento para os ricos, escola do acolhimento social para os pobres. Educação e Pesquisa, São Paulo, v. 38, p. $13-28,2012$.

A escola brasileira em face de um dualismo perverso: escola do conhecimento para os ricos, escola do acolhimento social para os pobres. ENCONTRO DE PESQUISA EM EDUCAÇÃO DA ANPED, 10. Anais... Uberlândia: 2010.

LIBÓRIO, Renata. M. C.; SOUSA, S. M. G. (Org.). A exploração sexual de crianças e adolescentes no Brasil: reflexões teóricas, relatos de pesquisa e intervenções psicossociais. São Paulo/Goiânia: Casa do Psicólogo, 2004.

LIBÓRIO, Renata. M. C.; SILVA, Divino J. Valores, preconceitos e práticas educativas. São Paulo: Casa do Psicólogo, 2005.

LIBÓRIO, Renata. M. C.; CASTRO, B. M. Dialogando sobre preconceitos, políticas de inclusão escolar e formação de professores. In: LIBÓRIO, Renata Maria Coimbra; SILVA, Divino José da (Org.). Valores, Preconceito e Práticas Educativas. São Paulo: Casa do Psicólogo, 2005. p. 73-114. 
LOPES, R. E.; SILVA, C. R.; MALFITANO, A. P. S. Adolescência e Juventude de Grupos Populares Urbanos no Brasil e as Políticas Públicas: Apontamentos Históricos. HISTEDBR, v. 23, p. 114-130, 2006.

LUKACS, G. Existencialismo ou marxismo. São Paulo: Senzala, 1967.

LYON-CALlO, Vincent. Cool Cities or Class Analysis: Exploring Popular Consent (?) to Neoliberal Domination and Exploitation. Rethinking Marxism, v. 20, n. 1, p. 28-41, jan. 2008.

MACHADO, V. R. A atual política de acolhimento institucional à luz do Estatuto da Criança e do Adolescente. Serviço Social em Revista, v. 13, p. 143-169, 2011. Disponível em: <www.uel.br/revistas/uel/index.php/ssrevista/article/view/10431>. Acesso em: 22 jun. 2014.

MANZINI, E. J. Entrevista semiestruturada: análise de objetivos e de roteiros. In: SEMINÁRIO INTERNACIONAL DE PESQUISA E ESTUDOS QUALITATIVOS, 2, A pesquisa qualitativa em debate. Anais..., Bauru: SIPEQ, 2004. 1 CD.

MARQUITT, Erwin. A contradição dialética não é uma contradição lógica. Ela apenas aparece como tendo a forma de uma contradição lógica. 43. ed. nov./jan. 1996-1997. p. 58-68. (Coleção Princípios). Disponível em: $<$ http://grabois.org.br/portal/cdm/revista.int.php?id_sessao=50\&id_publicacao=144\&id_indice=845>. Acesso em: 12 out. 2013.

MARTINS, José de Souza. Sociologia e militância. Estud. Av., São Paulo, v. 11, n. 31, dez. 1997. Disponível em: <www.scielo.br/scielo.php?script=sci_arttext\&pid=S0103-40141997000300011>. Acesso em: 16 set. 2014.

MARTINS, Lígia Márcia. As aparências enganam: divergências entre o materialismo histórico-dialético e as abordagens qualitativas de pesquisa. In: ENCONTRO BRASILEIRO DE EDUCAÇÃO E MARXISMO, 1. Anais... Bauru: Unesp, 2005. p. 28.

MARX, Karl. Manuscritos econômico-filosóficos. São Paulo: Martin Claret, 2003. 1984.

O capital: crítica da economia política. v. 1, Tomo 2. São Paulo: Abril Cultural, MARX, K.; ENGELS, F. Manifesto do Partido Comunista. São Paulo: Escriba, 1968. Contribuições da psicologia histórico-cultural para a pedagogia histórico-crítica. HISTEDBR, v. 13, 2013. Disponível em: <www.fe.unicamp.br/revistas/ged/histedbr/article/ viewFile/4092/4642>. Acesso em: 2 jul. 2014.

MASCARO, Alysson. Os direitos humanos e a dignidade humana. Revista MPD Dialógico, do Movimento do Ministério Público Democrático, ano V, nº 21, p. 20.

MEIRA, M. E. M.; ANTUNES, M. A. M. (Org.) Psicologia escolar: Práticas críticas. São Paulo: Casa do Psicólogo, 2003. 
MELLO, G. N. Fatores intraescolares como mecanismo de seletividade no ensino de $1^{\mathrm{o}}$ grau. Educação e Sociedade, São Paulo, ano 1, n. 2, p. 70-78, 1979.

Magistério de primeiro grau: da competência técnica ao compromisso político.

3. ed. São Paulo: Autores Associados e Cortez, 1983.

MESQUITA, Afonso Mancuso de. A motivação do aprendiz para a aprendizagem escolar: a perspectiva histórico-cultural. 2010. $118 \mathrm{f}$. Dissertação (Mestrado em Educação)-Universidade Estadual Paulista, Araraquara, 2010.

MESTRINER, Maria Luiza. O Estado entre a filantropia e a assistência social. 3. ed. São Paulo: Cortez, 2008.

MIOTO, Regina Célia. Trabalho com Famílias: um desafio para os Assistentes Sociais. Textos \& Contextos, n. 3, dez. 2004

MONTANO, C.; DURIGUETTO, M. L. Estado, classe e movimento social. 3. ed. , 2011. $384 \mathrm{p}$.

MOURA, Rivânia. Seguridade Social no Brasil: uma (des)construção inacabada. In: COLÓQUIO NACIONAL MARX E O MARXISMO. Anais... Niterói: UFF, 2011.

NASCIMENTO, Maria Livia do. Abrigo, pobreza e negligência: percursos de judicialização. Psicologia \& Sociedade, Belo Horizonte, v. 24, n. especial, p. 39-44, 2012.

NEVES, Ângela Vieira. Clientelismo, Cultura Política e democracia. Dilemas e desafios da Participação Popular - A experiência do Orçamento Participativo na cidade de Barra Mansa. Tese apresentada ao Instituto de Filosofia e Ciências Humanas da Universidade Estadual de Campinas, 2006.

NOSELLA, Paolo. A linha vermelha do planeta infância: o socialismo e a educação da criança. In: FREITAS, Marcos Cezar de; KUHLMANN JÚNIOR, Moysés (Org.). Os intelectuais na história da infância. São Paulo: Cortez, 2002. p. 129-166.

PAULANI, Leda. Acumulação sistêmica, poupança externa e rentismo: observações sobre o caso brasileiro. Estudos avançados, São Paulo, v. 27, n. 77, p. 237-264, 2013.

PEREIRA, Camila Potyara. Proteção social no capitalismo: contribuições à crítica de matrizes teóricas e ideológicas conflitantes. 2013. $307 \mathrm{f}$. Tese (Doutorado em Política Social)-Universidade de Brasília, Brasília, 2013.

PEREIRA, Kátia Regina do C. Diagnóstico de Dificuldade de Aprendizagem: construção, concepções e expectativas. 2011(a). Dissertação (Mestrado em Mestrado em Educação)Universidade de Brasília.

PEREIRA, Potyara A. P. Intersetorialidade das Políticas Sociais numa perspectiva dialética. 2011(b). Disponível em: <http://matriz.sipia.gov.br/images/acervo/Texto\%20Potyara \%20-\%20intersetorialidade.pdf>. Acesso em: 26 ago. 2014. 
2000 .

. Necessidades Humanas: subsídios à crítica dos mínimos sociais. São Paulo: Cortez,

Sobre a política de assistência social no Brasil. In: BRAVO, Maria Inês; PEREIRA, Potyara. (Org.) Política social e democracia. 2. ed. São Paulo: Cortez; Rio de Janeiro: UERJ, 2002.

Questão social, serviço social e direitos da cidadania. Temporalis, Porto Alegre, v. 2, n. 3, p. 51-61, 2001.

Perspectivas teóricas sobre a questão social no serviço social. Temporalis, Porto Alegre, v. 4, n. 7, p. 112-122, 2004.

A assistência social prevista na Constituição de 1988 e operacionalizada pela PNAS e pelo SUAS. Ser Social, Brasília, n. 20, p. 63-83, jan./jun. 2007. Disponível em: $<$ http://seer.bce.unb.br/index.php/SER_Social/article/view/251/1624>. Acesso em: 23 out. 2014.

Política social: temas \& questões. São Paulo: Cortez, 2008.

Política Social do Segundo Pós-Guerra. Ascensão e declínio. Revista Serviço Social \& Saúde. Unicamp, Campinas, v. IX, n. 10, dez. 2010. Disponível em: <www.bibliotecadigital.unicamp.br/document/?down=47803>. Acesso em: 15 fev. 2013.

Utopias desenvolvimentistas e política social no Brasil. Serviço Social \& Sociedade, n. 112, p. 729-753, 2012. Disponível em: <www.scielo.br/pdf/sssoc/n112/07.pdf>. Acesso em: 23 jul. 2013.

PONTES, Reinaldo. A categoria de mediação em face do processo de intervenção do serviço social. 1996. Disponível em: <www.ts.ucr.ac.cr/binarios/congresos/reg/slets/slets-016-104.pdf>. Acesso em: 23 out. 2014.

RIZZINI, Irene. O século perdido. Raízes históricas das políticas sociais para a infância no Brasil. 3. ed. São Paulo: Cortez, 2011.

RODRIGUES, Anegleyce. Gênese e sentido dos parâmetros curriculares nacionais e seus desdobramentos para a educação física escolar brasileira. Revista Brasileira de Ciências do Esporte, Campinas, v. 23, n. 2, p. 135-147, jan. 2002.

ROLIM, Dayana Cury. Efetividade do sistema de informação, monitoramento e avaliação da assistência social: Limites, Potencialidades e Desafios. 2009.166 f. Dissertação (Mestrado em Serviço Social)-Universidade Federal do Amazonas, Manaus, 2009.

ROSSETTI-FERREIRA, M. C.; SERRANO, Solange Aparecida; ALMEIDA, I. G. (Org.). O acolhimento institucional na perspectiva da criança. São Paulo: Hucitec, 2011.

SAES, Décio. Classe média e escola capitalista. Crítica Marxista, Campinas, n. 21, p. 97-112, nov. 2005. 
SALES, Mione. (In)visibilidade perversa: adolescentes infratores como metáfora da violência. São Paulo: Cortez, 2007.

SALINA-BRANDÃO, A.; WILLIAMS, L. C. A. O abrigo como fator de risco ou proteção: Avaliação institucional e indicadores de qualidade. Psicologia: Reflexão e Crítica, v. 22, n. 3, p. 334-343, 2009.

SANTOS, Érica. Produção do espaço urbano, politicas territoriais e a comparação entre as criminalidades em Brasília, Ceilândia e Taguatinga: uma questão de política, de segregação socioespacial ou de falta de presença do poder público? Geonorte, v. 7, ed. especial n. 3, p. 1686-1693, 2013.

SANTOS, M. S; MESQUIDA, P. As matilhas de Hobbes: o modelo da pedagogia por competência. São Paulo: Edumesp, 2007.

Escola pública e classes sociais no Brasil atual. Linhas Críticas, Brasília, v. 14, n. 27, p. 165-176, jul./dez. 2008

SAVELI, E. L. A educação obrigatória nas constituições brasileiras e nas leis educacionais delas derivadas. Contrapontos, Itajaí, v. 10, n. 2, p. 129-146, 2010.

SAVELI, E. L.; TENREIRO, M. O. A educação enquanto direito social: aspectos históricos e constitucionais. Teoria e Prática da Educação, Maringá, v. 15, p. 51-57, 2012.

SAVIANI, Demerval. Escola e Democracia. Ed. Comemorativa. Campinas: Autores Associados, 2008. 112 p.

. Trabalho e educação: fundamentos ontológicos e históricos. Revista Brasileira de Educação, v. 12, n. 34, jan./abr. 2007.

Educação: do senso comum à consciência filosófica. 18. ed. Campinas: Autores Associados, 2009.

A pedagogia histórico-crítica, as lutas de classe e a educação escolar. Germinal: Marxismo e Educação em Debate, Salvador, v. 5, n. 2, p. 25-46, dez. 2013.

SCHEINVAR, Estela. Conselho tutelar e escola: a potência da lógica penal no fazer cotidiano. Psicologia \& Sociedade, Belo Horizonte, v. 24, n. especial, 2012. Disponível em: $<$ www.scielo.br/scielo.php?script=sci_arttext\&pid=S0102-71822012000400008>. Acesso: em: 1 nov. 2014.

SEABRA, Raphael Lana. Da contradição à elaboração: Crítica da alienação da sociedade capitalista - Dissertação (Sociologia) - Universidade de Brasília, 2008.

SHIROMA, E. O.; CAMPOS, R. F. La resignificación de la democracia escolar mediante el discurso gerencial: liderazgo, gestión democrática y gestión participativa. In: FELDFEBER, Myriam; OLIVEIRA, Dalila (Org.). Políticas educativas y trabajo docente: Nuevas regulaciones, Nuevos sujetos? Buenos Aires: Novedades Educativas, 2006. 
SILVA, Enid Rocha A. O perfil da criança e do adolescente nos abrigos pesquisados. In: SILVA, E. R. A. (Org.). O direito à convivência familiar e comunitária: os abrigos para crianças e adolescentes no Brasil. Brasília: Disoc/Ipea/Conanda, 2004.

SILVA, Luís Gustavo. Plano Nacional de Educação: uma avaliação das diferentes concepções de gestão educacional em disputa. Linhas Críticas, Brasília, v. 13, n. 25, p. 253-270, jul./dez. 2007.

SILVA, Maria Abádia da. O consenso de Washington e a privatização na educação brasileira. Linhas Críticas, Brasília, v. 11, n. 21, p. 255-264, jul./dez. 2005.

Qualidade social da educação pública: algumas aproximações. Cadernos CEDES, Campinas, v. 29, n. 78, ago. 2009.

SILVA, Maria Ozanira da Silva e. Pobreza, desigualdade e políticas públicas: caracterizando e problematizando a realidade brasileira. Katálysis, Florianópolis, v. 13, n. 2, p. 155-163, 2010.

SIQUEIRA, L. B.; ALENCAR, O. L. G.; AQUINO, C. A. B. Atividade humana: compreendendo a trajetória do trabalho na contemporaneidade. Revista de Psicologia, Fortaleza, p. 80-93, jan./jun. 2012.

SOARES DA COSTA, César Augusto. Premissas conceituais sobre a formação do materialismo de Marx. Prax. filos. (online). n. 31, p. 61-72, 2010. Disponível em: $<w w w . s c i e l o . o r g . c o / s c i e l o . p h p ?$ script=sci_arttext\&pid=S0120-46882010000200004>. Acesso em: 9 fev. 2015. (ISSN 0120-4688).

SODRÉ, Nelson Werneck. Síntese de história da cultura brasileira. 3. ed. Rio de Janeiro: Civilização Brasileira, 1974.

SOUSA, Adinari. $O$ trabalho do assistente social na política de assistência social: a experiência de Fortaleza-CE à luz do projeto ético-político profissional. Tese (Doutorado em Política Social)-Universidade de Brasília, Brasília, 2013.

SOUZA, F. H. O.; CUNHA, Eduardo L. A esperança na família: uma leitura psicanalítica do acolhimento institucional. Epos, v. 2, p. 578, 2011.

SOUZA, Marilene Proença Rebello de; TEIXEIRA, Danile Caetano da Silva; SILVA, Maria Carolina Yazbek Gonçalves da. Conselho Tutelar: um novo instrumento social contra o fracasso escolar? Psicologia em estudo, Maringá, v. 8, n. 2, dez. 2003. Disponível em: $<$ www.scielo.br/scielo.php?script=sci_arttext\&pid=S1413-73722003000200008>. Acesso em: 1 nov. 2014.

SOUZA, Sandra Zákia Lian de; OLIVEIRA, Romualdo Portela de. Políticas de avaliação da educação e quase mercado no Brasil. Educação \& Sociedade. Campinas, v. 24, n. 84, p. 873-895, 2003.

TACCA, Maria Carmen Villela Rosa; BRANCO, Angela Uchoa. Processos de significação na relação professor-alunos: uma perspectiva sociocultural construtivista. Estudos de psicologia, Natal, v. 13, n. 1, abr. 2008. Disponível em: <www.scielo.br/scielo.php?script=sci_arttext\& pid=S1413-294X2008000100005>. Acesso em: 31 ago. 2014. 
TEIXEIRA, Rodrigo Alves; PINTO, Eduardo Costa. A economia política dos governos FHC, Lula e Dilma: dominância financeira, bloco no poder e desenvolvimento econômico. Economia e sociedade, v. 21, n. especial, p. 909-941, 2012.

TONET, Ivo. Cidadania ou Emancipação Humana? Espaço Acadêmico, Maringá, n. 44, 2005. Disponível em: <www.espacoacademico.com.br/044/44ctonet.htm>. Acesso em: 28 jul. 2014.

VYGOTSKY, L.S. A formação social da mente. 6. ed., São Paulo: Martins Fontes, 1998. $218 \mathrm{p}$.

YANNOULAS, Sílvia (Coord.). Política educacional e pobreza: múltiplas abordagens para uma relação multideterminada. Brasília: LiberLivro, 2013. 280 p.

ZAGO, Luís Henrique. O método dialético e a análise do real. Kriterion, Belo Horizonte, v. 54, n. 127, jun. 2013. Disponível em: <www.scielo.br/scielo.php?script=sci_arttext\&pid= S0100-512X2013000100006>. Acesso em: 25 nov. 2014. 


\section{ANEXOS}

Anexo A - Formulário aplicado em entrevista às professoras

Anexo B - Formulário aplicado em entrevista às professoras sobre os alunos acolhidos

Anexo $\mathrm{C}$ - Formulário aplicado em entrevista às diretoras das escolas

Anexo D - Formulário aplicado em entrevista às coordenadoras das unidades de acolhimento

Anexo E - Formulário aplicado em entrevista à gestora distrital da Secretaria de Educação

Anexo F - Formulário aplicado em entrevista à gestora distrital da Secretaria de Estado de Desenvolvimento Social e Transferência de Renda

Anexo $\mathrm{G}$ - Termo de Consentimento para profissionais da escola, do acolhimento, e para gestoras distritais da Assistência Social e Educação 
Anexo A - Formulário aplicado em entrevista às professoras

\section{ENTREVISTA SEMIESTRUTURADA COM PROFESSORES/AS DE ESCOLAS PÚBLICAS COM ALUNOS EM ACOLHIMENTO INSTITUCIONAL}

Marque um $x$ na alternativa mais adequada à questão:

1. Você tem conhecimento dos seguintes artigos do ECA no tocante ao direito à Educação?

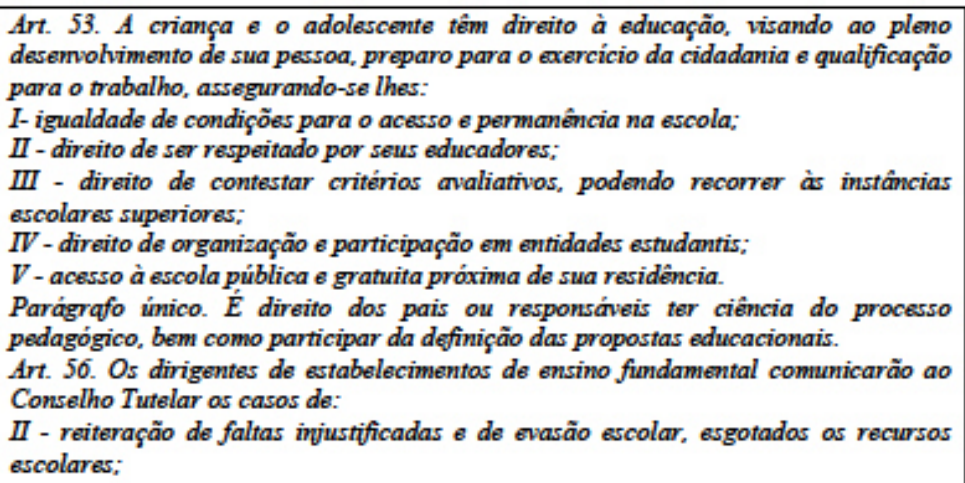

II - reiteração de faltas injustificadas e de evasão escolar, esgotados os recursos escolares:

( ) $\operatorname{sim}($ ) não

2. E no tocante às medidas de proteção?

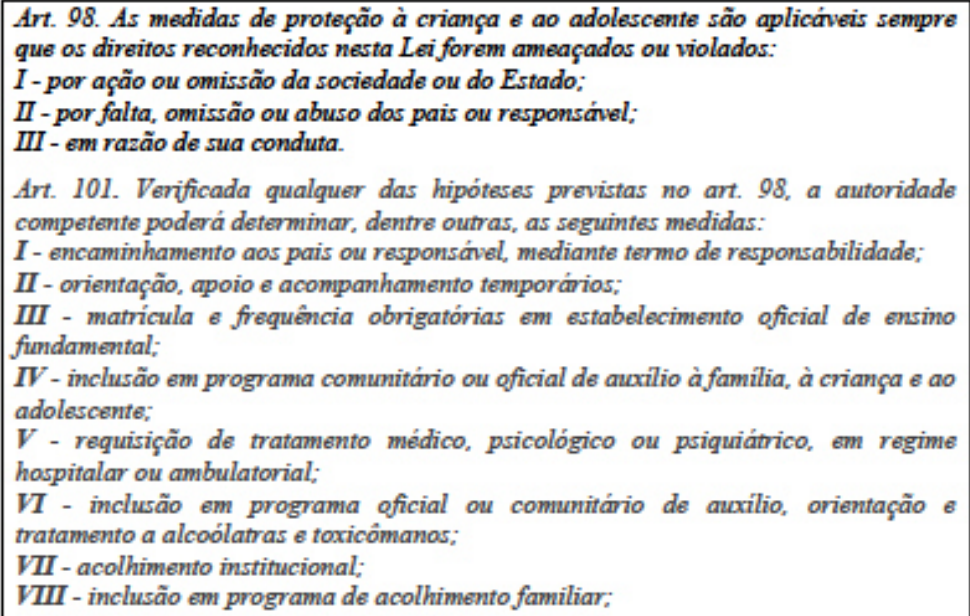

IV - inclusão em programa comunitário ou oficial de auxilio à família, à criança e ao adolescente;

$\boldsymbol{V}$ - requisição de tratamento médico, psicológico ou psiquiátrico, em regime hospitalar ou ambulatorial;

VI - inclusão em programa oficial ou comunitário de auxilio, orientação e tratamento a alcoólatras e toxicômanos:

VII-acolhimento institucional;

VIII - inclusão em programa de acolhimento familiar.

$\boldsymbol{L}$ - colocação em familia substituta
( ) $\sin$ ( ) não 
Marque um $x$ na(s) alternativa(s) correta(s) para a situação:

3. Como tomou conhecimento desses artigos do Estatuto da Criança e do Adolescente:

( ) Em cursos na escola ( ) Em cursos fora da escola ( ) Durante a formação em nível superior ( ) Outra alternativa

Responda com suas palavras:

4. Que tipo de dificuldades e problemas escolares são frequentes para os alunos em geral e que se repetem com os alumos em acolhimento institucional? Cite três no máximo.

\section{Responda com suas palavras:}

5. Algum outro problema em especial para os acolhidos? Cite três relevantes no máximo.

6. Que medidas são tomadas por você frente a problemas de aprendizagem que podem vir a resultar em evasão ou numa permanência pouco proveitosa para o aluno? Cite até três medidas

Marque um x na(s) alternativa(s) correta(s) para a situação:

7. Quem procura para ajudá-lo dentro da escola nesses momentos de dificuldade na aprendizagem?

( ) Direção ( ) Orientadora educacional ( ) Equipe Psicopedagógica ( ) A Regional de Ensino ( ) Demais professores formalmente ( ) Demais professores informalmente em reunião pedagógica ( ) Outros. Quem?

\section{Marque um x na alternativa correta}

8. Há publicações disponiveis na escola para consulta no tocante à aprendizagem e as particularidades de alunos em acolhimento institucional? (Não se trata do ECA/1990).

( ) $\operatorname{sim}($ ) não

Marque um x na(s) alternativas correta(s) para a situação:

9. Onde está o seu limite para a resolução (sem a ajuda de terceiros) das questões de conflito ou agressividade para com esses ou quaisquer alunos?

( ) Quando o aluno aparenta não se afetar pelos conselhos e conversas.

( ) Quando o aluno repete as atitudes.

( ) Outros. Cite até duas situações.

( ) Não tenho experiências assim em classe.

10. Onde pensa que está o limite da unidade de acolhimento para a resolução dessas questões de aprendizagem/ comportamento? ( ) na falta de profissionais ( ) na falta de estrutura fisica ( ) outro. Cite até três limites 


\section{Responda com suas palavras:}

11. Quais características positivas apontaria nos alunos em acolhimento institucional? Cite até três.

12. Que fatores, em geral, podem desencadear indisciplina em classe por parte dos alunos acolhidos? Cite até três fatores.

\section{Marque um I na(s) alternativa(s) correta(s) para a situação:}

13. O que você faz para adequar cotidianamente seu plano de aula e as atividades extraclasse às necessidades especificas de alunos que vivem sob acolhimento?

( ) Busco textos que contemplam suas vivências.

( ) Cito exemplos próximos às vivências deles.

( ) Não peço aos alunos tarefas de casa que demandem a existência de uma familia, buscando substitui-las por outras.

( ) Busco preservá-los de situações que os constranjam, por se remeterem a vivencias das quais eles não podem partilhar.

( ) Outras possibilidades. Até três:

\section{Marque um x na alternativa correta para a situação hoje vivida:}

14. A estigmatização de alunos acolhidos pelos demais, é fator relevante em seu cotidiano a ponto de interferir na disciplina?

( ) $\operatorname{sim}$ ( ) não ( ) parcialmente

15. Você acredita que no PPP da escola deveria estar prevista a aspiração por medidas conjuntas com a unidade de acolhimento no tocante a aspectos que permitam uma maior aprendizagem das crianças? ( ) $\operatorname{sim}($ )não

16. Você acredita que a realidade em que se situam os alunos acolhidos, não somente os seus, demandaria a presença de outros profissionais (não docentes) na escola para que o trabalho docente efetivamente garantisse uma permanência com aprendizagem?
( ) $\operatorname{sim}$ Quais?
( ) não 
Anexo B - Formulário aplicado em entrevista às professoras sobre os alunos acolhidos

\section{DESEMPENHO DO/A ALUNO/A ACOLHIDO/A}

\section{CÓDIGO DA PROFESSORA}

Marque um $x$ na resposta mais adequada:

1. A criança é ( ) menino ( ) menina

2. Qual a idade? ( )6( )7 ( )8( )9( )10( )11( )12( ) 13( )14

3. Cursa que ano de escolaridade? $1^{\circ}\left(\right.$ ) $2^{\circ}() 3^{\circ}() 4^{\circ}() 5^{\circ}($ )

4. Está fora da faixa idade/ano de escolaridade? ( ) sim ( )não

5. No tocante à aprendizagem apresenta ( )bom aproveitamento ( )aproveitamento mediano ( )baixo aproveitamento

6. A criança já foi encaminhada para a equipe de diagnóstico? ( ) sim ( )não. Caso sim, responda a questão número 7. Caso não tenha sido necessário encaminhá-la, pule para a questão número 8 .

7. Já recebeu parecer da equipe de diagnóstico? ( ) sim. Qual?

( ) não

8. A criança chega à sala de aula com dores e/ou mal estar?

( )poucas vezes ( ) com bastante frequência ( )raramente ( )isso não acontece.

9. Sempre cumpre as tarefas de casa?

( ) sim ( )parcialmente ( )não. Caso não cumpra, passe para a pergunta 10. Caso o faça vá para a questão 11.

Marque um x nas respostas adequadas:

10. Que motivos você alega para o não cumprimento das tarefas de casa?

( )ela não entende as tarefas ( )falta acompanhamento de adultos ( )há um constante extravio das tarefas da escola para casa ( ) a criança relata problemas para executar as tarefas. Quais?

( )motivos de outra ordem

Quais?

Marque um $x$ na resposta mais adequada:

11. Como a criança se mostra na maioria das vezes?

Quanto às atividades em classe:

( )atenta à resolução das atividades propostas ( )quase sempre atenta à resolução das atividades propostas ( ) dispersa para a resolução das atividades propostas.

\section{Quanto aos conteúdos:}

( )bastante interessada nos conteúdos ( )medianamente interessada nos conteúdos ( )pouco interessada nos conteúdos ( ) interessada mediante a intervenções mais individualizadas por parte da/o docente.

Quanto à vivência em ambiente escolar, como ela se apresenta? 
( )não adaptada aos usos e fazeres da escola

( ) Jem adaptação aos usos e fazeres da escola ( ) bem adaptada aos usos e fazeres da escola

12. Do ponto de vista da interação com os colegas em classe:

( )a criança se mostra bem interada ( )a criança se intera com poucos colegas ( )a criança não se intera com os colegas

13. Como situa a sua relação com a criança?

( ) conflituosa quase sempre ( )harmoniosa quase sempre ( )conflituosa ( )harmoniosa

14. É uma criança que já recebeu advertências orais esse ano? ( ) sim ( ) não

15. É uma criança que já recebeu advertências escritas esse ano? ( fora da situação de sala, como preconiza o Regimento Escolar)

( ) $\operatorname{sim}($ )não

16. É uma criança que já recebeu suspensão esse ano? (fora da situação de sala, como preconiza o Regimento Escolar)

( ) $\operatorname{sim}($ )não

17. É uma criança considerada faltosa?

( ) sim. Quantas faltas até aqui? ( ) não

\section{Marque um $x$ nas respostas adequadas:}

18. Quais outras dificuldades percebe com mais destaque nesse aluno?

- dificuldade em entender os conteúdos ( )

- dificuldade em cumprir com as tarefas de casa( )

-descuido com os materiais escolares( )

-atrasos na chegada à escola( )

- dificuldade em manter-se em sala de aula, buscando sair dela repetidas vezes( )

- choro aparentemente imotivado( )

- mau relacionamento com outros/as professore/as( )

- mau relacionamento com a direção e auxiliares de ensino( )

- faltam as vivências requeridas por alguns conteúdos escolares( )

- agressividade e indisciplina cotidianas( )

- reclamação quanto à escola e seu papel na vida dele( )

- necessidade de retornar à unidade de acolhimento antes do término do turno por indisciplina.

( )

- nenhuma das alternativas anteriores se aplicam ao aluno ( )

19. Na qualidade de docente, sente liberdade para expor aos responsáveis (cuidadores/as) por cada criança e adolescente do abrigo as dificuldades encontradas durante a vida escolar?

( ) $\operatorname{sim}$

( ) não. Quais ?

20. Encontra respostas adequadas por parte do/as cuidadore/as e dos abrigos a essas dificuldades? ( ) Sim ( ) Não

Marque um $\mathbf{n}$ na resposta mais adequada: 
21. Sobre as informações da unidade de acolhimento acerca do andamento da vida desse aluno em acolhimento institucional:
a) é informada/o se ele aguarda adoção? ( ) $\operatorname{sim}($ ) não ( )parcialmente
b) é informada/o se ele está em fase de reintegração ao lar? ( )sim ( )não ( )parcialmente.
c) é informada/o dos motivos que o levam a faltar à escola eventualmente?
( ) $\operatorname{sim}$ ( )não ( )parcialmente
d) é informada sobre a existência de uma possivel familia e de seu direito de vir à escola para vê-lo quando não há impedimentos judiciais?
( ) $\operatorname{sim}($ )não ( )parcialmente
e) é informada sobre os motivos que o levaram ao acolhimento?
( ) $\operatorname{sim}($ )não ( )parcialmente
22. A criança já foi encaminhada para a Orientação Educacional?
( )não ( ) sim. Por que razão?

\section{Marque um $x$ nas respostas adequadas:}

23. Que motivos na realidade de hoje poderiam levar essa criança, em acolhimento institucional, à uma evasão ou a uma permanência pouco proveitosa?

( ) muitas faltas à escola

( ) mal estares ou adoecimento repetidas vezes ou contínuo, inclusive em sala

( ) desmotivação frente às aulas

( ) dificuldade com os conteúdos apresentados

( ) falta de acompanhamento de seus responsáveis

( ) estigma sofrido por ela

( ) despreparo da escola para com ela

( ) falta de pessoal qualificado para lidar dentro da escola com as problemáticas enfrentadas pela criança que extrapolam à função docente.

( ) fatores externos competem com a escola. Cite até três

( ) outros motivos não elencados. Cite até três.

( ) no momento não haveria motivos para evasão e nem se verifica uma permanência pouco proveitosa.

\section{Marque um $x$ na resposta mais adequada:}

24. Em sua avaliação, qual o papel predominante da escola na vida acadêmica desse aluno?

( ) de acolhedora social (lugar de encontro, de compartilhamento e de solidariedades)

( ) de espaço de transmissão de conteúdos e de aprendizagem.

25. Seria relevante destacar algum fator de ordem emocional ou física quanto ao aluno?

( )não ( ) sim Qual? 
Anexo C - Formulário aplicado em entrevista às diretoras das escolas

\section{ENTREVISTA SEMIESTRUTURADA COM GESTORES DA ESCOLA (DIREÇÃO OU VICE-DIREÇẪO) \\ CÓDIGO DO/A DIRETOR/A}

\section{Marque um $x$ na resposta mais adequada:}

1. A equipe gestora tem conhecimento dos seguintes artigos do ECA no tocante ao direito à Educação?

Art. 53. A criança e o adolescente têm direito à educação, visando ao pleno desenvolvimento de sua pessoa, preparo para o exercício da cidadania e qualificação para o trabalho, assegurando-se-lhes:

I- igualdade de condições para o acesso e permanência na escola;

II - direito de ser respeitado por seus educadores;

III - direito de contestar critérios avaliativos, podendo recorrer às instâncias escolares superiores;

IV - direito de organização e participação em entidades estudantis;

V - acesso à escola pública e gratuita próxima de sua residência.

Parágrafo único. É direito dos pais ou responsáveis ter ciência do processo pedagógico, bem como participar da definição das propostas educacionais.

Art. 56. Os dirigentes de estabelecimentos de ensino fundamental comunicarão ao Conselho Tutelar os casos de:

II - reiteração de faltas injustificadas e de evasão escolar, esgotados os

( ) $\operatorname{sim}$ ( ) não recursos escolares;

\section{E no tocante às medidas de proteção?}

Art. 98. As medidas de proteção à criança $\mathrm{e}$ ao adolescente são aplicáveis sempre que os direitos reconhecidos nesta Lei forem ameaçados ou violados:

I - por ação ou omissão da sociedade ou do Estado;

II - por falta, omissão ou abuso dos pais ou responsável;

III - em razão de sua conduta.

Art. 101. Verificada qualquer das hipóteses previstas no art. 98, a autoridade competente poderá determinar, dentre outras, as seguintes medidas:

I - encaminhamento aos pais ou responsável, mediante termo de responsabilidade;

II - orientação, apoio e acompanhamento temporários;

III - matrícula e frequência obrigatórias em estabelecimento oficial de ensino fundamental;

IV - inclusão em programa comunitário ou oficial de auxilio à familia, à criança e ao adolescente;

$\mathrm{V}$ - requisição de tratamento médico, psicológico ou psiquiátrico, em regime hospitalar ou ambulatorial;

VI - inclusão em programa oficial ou comunitário de auxilio, orientação e tratamento a alcoólatras e toxicômanos;

VII - acolhimento institucional;

VIII - inclusão em programa de acolhimento familiar;

( ) $\operatorname{sim}$ ( ) não IX - colocação em família substituta. 


\section{Responda às perguntas a seguir:}

3. Qual o total de alunos e de alunas acolhidos institucionalmente?

4. Dispersos em que anos escolares?

5. Quantos diria que tem bom aproveitamento?

6. Quantos caracterizaria como alunos com baixo aproveitamento?

7. Quantos são infrequentes? Como enfrentam o baixo rendimento escolar?

8. Quais caracteristicas positivas apontaria nos alunos em acolhimento institucional? Cite até três.

9. Que tipo de dificuldades e problemas escolares são frequentes para os alunos em geral e que se repetem com os alunos em acolhimento institucional? Cite até três.

Marque um x somente naquelas alternativas que considerar mais expressivas:

10. Quais dificuldades e problemas percebe com mais destaque (frequência) nos alunos acolhidos?

- dificuldade em manter atenção nas atividades ( )

- falta de interesse para com as atividades.( )

- dificuldade em entender os conteúdos.( )

- dificuldade em cumprir com as tarefas de casa.( )

-descuido com os materiais escolares.( )

-atrasos na chegada à escola.( )

- dificuldade em manter-se em sala de aula, buscando sair dela repetidas vezes.( )

- choro aparentemente imotivado.( )

- mau relacionamento com professores.( )

- mau relacionamento com a direção e auxiliares de ensino.( )

- mau relacionamento com os colegas.( )

- faltam as vivências requeridas por alguns conteúdos escolares.( )

- agressividade e indisciplina cotidianas.( )

- reclamação quanto à escola e seu papel na vida deles.( )

- necessidade de retornar à unidade de acolhimento antes do término do turno por indisciplina. ( )

- alunos fora de faixa etária para o ano de escolaridade em curso ( )

- atrasos em função do transporte que utiliza ( )

11. Algum outro problema em especial para os acolhidos? Cite três relevantes no máximo.

12. O que a escola faz com problemas que podem vir a resultar em evasão? Cite até três medidas.

Marque um x nas diferentes ocorrências:

13. A quem a escola recorre nessas situações? 
( ) ao professor do aluno ( ) ao orientador educacional ( ) à equipe de diagnóstico ( ) à unidade de acolhimento ( ) ao Conselho Tutelar ( ) outros.

Quem?

\section{Marque um $x$ apenas na resposta correta:}

14. A escola costuma se reunir com membros da unidade de acolhimento para planejamento das suas atividades pedagógicas ou outros fins?

() sim. Caso existam outras finalidades, cite até três.

( ) não.

15. Em relação ao PPP da escola existe alguma medida prevista para garantir uma a permanência dos alunos na escola e a participação do abrigo nesse propósito conjunto? ( ) sim ( ) não ( ) parcialmente

16. O conselho escolar se encontra fortalecido como instância de decisão na escola?( ) sim ( )não. Qual a periodicidade das reuniões?

( )semanais ( )quinzenais ( )mensais ( ) semestrais ( )sem periodo fixo

17. O abrigo tem assento no Conselho Escolar? ( ) sim ( )não

\section{Marque um $x$ nas respostas corretas:}

18. Quem tem assento no conselho? ( ) pais/responsáveis ( ) alunos. Criança ou adolescente ? ( ) professores ( ) auxiliares de ensino.

19. Acredita que a gestão tem um trato democrático com todas as crianças nas distintas situações?( ) sim ( )não( )parcialmente.

20. A livre expressão de ideias é permitida em âmbito escolar, possibilitando que as crianças e adolescentes em acolhimento institucional respondam às demandas escolares e mesmo à alguma estigmatização?

( ) sim ( )não ( )é parcialmente livre. Por que?

\section{Marque um $x$ apenas nas respostas que forem adequadas:}

21. Como o planejamento das atividades de classe e extraclasse desta unidade escolar permite que alunos acolhidos institucionalmente se sintam verdadeiramente incluídos?

( ) No planejamento são respeitadas as dificuldades deles quanto a pesquisa domiciliar no tocante a evocação de memórias que remetem à familia.

( ) No planejamento das festas e atividades escolares, busca-se não expor as crianças a situações que revelem suas perdas afetivas de modo indelicado.

( ) Há um cuidado na exploração de conteúdos muito divergentes/distantes das realidades dos alunos, criando-se mecanismos para aproximá-los dos discentes.

\section{Marque um $x$ apenas na resposta adequada:}

22. Como a escola se articula com o abrigo para ser veículo de proteção ao aluno acolhido institucionalmente? 


\section{( ) com medidas conjuntas \\ ( ) com reuniões periódicas \\ ( ) a escola não faz formalmente esse tipo de articulação}

Cite o que considerar importante:

23. No tocante à indisciplina, que medidas são tomadas pela escola com alunos acolhidos e não acolhidos? Cite as medidas cotidianas.

\section{Marque um $x$ na resposta adequada:}

24. A tomada de providencia quanto ao ocorrido é a mesma para os dois grupos de alunos? ( ) sim ( ) não. Explique:

25. Já viu ou sentiu a estigmatização dos alunos acolhidos por algum segmento da escola?

( ) $\operatorname{sim}$ Quais as medidas tomadas. Até três medidas.

( ) não.

26. Como a escola se relaciona com o Conselho Tutelar (CT) local no tocante às crianças acolhidas? ( )bem ( )muito bem ( )mal ( )bem, mas com algumas críticas.

Quais?

( ) não precisou se relacionar com o CT no caso de alunos acolhidos.

27. A escola está satisfeita com a maneira em que lida com a indisciplina particularmente dos alunos acolhidos? ( )sim ( ) não ( )parcialmente

\section{Assinale o número que mais se aproxima à realidade:}

28. Qual a média semanal de alunos acolhidos chamados à direção para algum tipo de advertência, suspensões ou conversa sobre indisciplina?

( ) advertências ( )conversas ( )suspensões ( )não é o caso

\section{Marque um $x$ apenas na resposta adequada:}

29. A escola acredita que essas advertências ou suspensões podem resultar em evasão?

( ) $\operatorname{sim}($ ) não

$\mathrm{O}$ que tem feito para diminú-las em colaboração com o abrigo?

( ) Nenhuma medida ainda ( ) Algumas medidas. Cite três.

30. A escola está satisfeita com a maneira com que o abrigo lida com a indisciplina das crianças e adolescentes acolhidos? ( ) Sim ( )Não ( )Parcialmente.

31. A escola conhece o PPP do abrigo particularmente no tocante à escolarização das crianças e adolescentes? ( )Sim ( )Não

32. A escola está satisfeita com a maneira com que o abrigo lida com as questões pedagógicas

? ( ) $\operatorname{sim}($ ) não 
33. A escola já se viu impotente ou sem quaisquer alternativas para garantir a permanência escolar ao enfrentar a alguma situação envolvendo alunos acolhidos?

\section{( ) $\sin ($ ) não}

34. A escola já desenvolveu algumas medidas para facilitar a adaptação de alunos acolhidos aos seus fazeres e rotinas?

( ) $\operatorname{sim}($ ) não

35. Há recorrência em suspensões com alunos acolhidos? ( )sim ( )não ( )nunca suspendemos. As suspensões se repetem mais entre eles ou entre os demais alunos? ( )entre os acolhidos ( )entre os demais alunos.

Marque um $x$ em todas as alternativas que considerar corretas:

36. O que gera indisciplina em classe por parte dos alunos acolhidos?

( ) a estigmatização que sofrem ( ) a continuidade de brigas que começaram na unidade de acolhimento ( ) a não adaptação à rotina da escola ( ) o despreparo da escola para lidar com esses alunos ( ) outros motivos. Quais?

A partir de sua experiência, marque um $x$ na resposta correta, mesmo que não tenha advertido ou suspenso alunos acolhidos:

37. Acredita que as advertências orais e escritas para esses alunos resultam em algo positivo para os trabalhos de classe?

( ) $\operatorname{sim}($ )não ( )parcialmente

38. E repercutem bem para os próprios alunos advertidos? ( ) $\operatorname{sim}$ ( ) não ( ) parcialmente

39. E as suspensões? Repercutem positivamente para os trabalhos em classe?

( ) $\operatorname{sim}($ )não ( )parcialmente

40. E repercutem positivamente para o aluno suspenso? ( )sim ( )não ( ) parcialmente. Ele volta melhor? ( ) sim ( )não ( )parcialmente

41. A escola relaciona advertências e suspensões à possível evasão escolar ou desmotivação do aluno? ( ) sim ( )não

\section{Marque todas as alternativas que considerar corretas:}

42. Que motivos levam à evasão desses alunos ou a uma permanência pouco proveitosa? ( ) desmotivação do aluno ( ) dificuldade com os conteúdos apresentados ( ) falta de acompanhamento de seus responsáveis ( ) estigma sofrido por eles ( ) despreparo da escola para com eles ( ) fatores externos competem com a escola. Cite até três.

( ) outros motivos não elencados. Cite até três.

\section{Marque um x na alternativa que considerar correta:}

43. Há publicações disponiveis (livros, apostilas, revistas, CD ROM, etc) na escola para pesquisa no tocante à aprendizagem $\mathrm{e}$ as particularidades de alunos em acolhimento institucional? (Não se trata do ECA/1990). ( ) sim ( ) não 
44. Sente falta de profissionais mais preparados no conjunto da rede de ensino (escola, Regional de Ensino e Secretaria de Educação) para lidar com as questões de aprendizagem/comportamento relativas aos alunos acolhidos?

( ) $\operatorname{sim}($ )não

45. A escola atua em rede para garantir a permanência escolar do aluno acolhido?

( ) Sim, mas busca-se serviços que pertencem à própria Secretaria de Educação.

( ) Sim. Inclusive, busca-se serviços fora da Secretaria de Educação. Quais?

( ) Não. Atua-se solitariamente. 
Anexo D - Formulário aplicado em entrevista às coordenadoras

das unidades de acolhimento

\section{ENTREVISTA SEMIESTRUTURADA COM COORDENADOR DA UNIDADE DE ACOLHIMENTO CÓDIGO DO/A COORDENADORA}

\section{Responda}

a) Quantas crianças estão acolhidas nesta unidade? (de 6 a 10 anos)

b) Quantas frequentam do $1^{\circ}$ ao $5^{\circ}$ ano?

c) Quantas frequentam do $1^{\circ}$ ao $5^{\circ}$ ano e já possuem mais de 11 anos?

d) Há algum acolhido que, mesmo estando matriculado entre o $1^{\circ}$ e o $5^{\circ}$ ano, não frequenta a escola? Caso exista, responda o porquê.

e) Quem responde por cada aluno dentro da escola no tocante ao recebimento dos resultados bimestrais? Essa mesma pessoa faz o acompanhamento escolar do aluno dentro da unidade de acolhimento?

\section{Marque um $x$ nas respostas adequadas:}

a) $\mathrm{O}$ que a unidade de acolhimento proporciona aos acolhidos que contribui para a escolarização dos mesmos?

( ) biblioteca com horánios regulares de funcionamento.

( ) profissional com graduação para acompanhar nas "tarefas de casa" enviadas pela escola. O profissional é voluntário? Qual a graduação?

( ) sala de reforço aberta regularmente.

( ) sala para fazer as tarefas de casa enviadas pela escola.

( ) material para pesquisa como enciclopédias, revistas ou jomais.

( ) computador com $c d$ rom.

( ) computador com internet.

\section{Responda:}

a) Quais as atividades realizadas pela unidade de acolhimento que podem contribuir para uma boa escolarização das crianças?

b) $\mathrm{O}$ que pode prejudicar no cotidiano da unidade de acolhimento a escolarização das crianças?

c) Há condições de estudar dentro dos quartos ou os acolhidos precisam sair deles para realizar a tarefa?

d) Qual o grau de escolaridade de todas as cuidadoras?

e) Qual a maior dificuldade na escolarização sentida pelos alunos em acolhimento?

f) $O$ que entende que falta aos alunos para obterem melhor desempenho?

g) Quais as reclamações que os alunos fazem da escola?

h) Quais os elogios?

i) A unidade de acolhimento tem uma boa relação com a direção da escola?

j) A unidade de acolhimento tem uma boa relação com cada professora da escola? 
k) O que a escola tem pedido a unidade de acolhimento que ela não tem cumprido?

1) $\mathrm{O}$ que a escola tem pedido a unidade de acolhimento que ela tem cumprido?

$\mathrm{m})$ Quais as duas maiores reclamações da escola quanto aos alunos acolhidos?

n) Quais as dois elogios mais incidentes da escola quanto aos alunos acolhidos?

o) Há uma rotina diária para os acolhidos fazerem as tarefas escolares ou estudarem para as avaliações?

p) Há um local para que os acolhidos guardem seu material escolar?

q) Qual o cuidado tomado para que os acolhidos superem dificuldades escolares?

r) Todos os acolhidos comparecem ao reforço escolar quando convocados por suas professoras?

s) Quais são os problemas que mais levam a unidade de acolhimento a ser chamada a comparecer à escola?

t) O que gostaria de ver melhorado na escola no tocante ao atendimento dos acolhidos?

u) A unidade de acolhimento leva as crianças ao reforço escolar quando as mesmas são chamadas para essa atividade?

v) Como caracterizaria a relação com a escola?

w) Gosta da forma como a escola encaminha as questões de indisciplina?

x) A unidade de acolhimento já cogitou fazer parte do Conselho Escolar?

z) A unidade de acolhimento já participou da construção do Projeto Político Pedagógico da escola? Levou suas demandas?

\section{Marque um $x$ nas respostas adequadas:}

a) Que motivos levam o aluno a evadir da escola ou a ter uma prática pouco proveitosa dentro dela?

( ) desmotivação do aluno ( ) dificuldade com os conteúdos apresentados ( ) falta de acompanhamento de seus responsáveis ( ) estigma sofrido por eles ( ) despreparo da escola para com eles ( ) fatores externos competem com a escola. Cite até três.

( ) outros motivos não elencados. Cite até três.

b) Como a escola se articula com o abrigo para ser veículo de proteção ao aluno acolhido institucionalmente?

() com medidas conjuntas

() com reuniões periódicas

() a escola não faz formalmente esse tipo de articulação

4. Marque um $x$ na resposta adequada:

a) Sente falta de profissionais mais preparados no conjunto da rede de ensino (escola, Regional de Ensino e Secretaria de Educação) para lidar com as questões de aprendizagem/comportamento relativas aos alunos acolhidos?

( ) $\operatorname{sim}($ ) não 
b) A escola costuma se reunir com membros da unidade de acolhimento para planejamento das suas atividades pedagógicas ou outros fins?

( ) sim. Caso existam outras finalidades, cite até

três.

( ) não. 
Anexo E - Formulário aplicado em entrevista à gestora distrital da Secretaria de Educação

\section{ENTREVISTA COM A SECRETARIA DE EDUCAÇÃO DO DISTRITO FEDERAL}

a) Que demandas e de quais setores geraram a construção do GT Educação/Serviços de Acolhimento entre a SEDEST e a SEDF?

b) A primeira iniciativa de encontro para viabilizar medidas conjuntas para os alunos acolhidos da Escola Pública partiu de qual Secretaria?

c) Quais eram as expectativas do setor frente aos primeiros encontros até formar o GT?

d) Qual o papel das políticas traçadas em nível federal na gestão da educação no Distrito Federal, particularmente para grupos como os dos alunos acolhidos?

e) Existe algum mecanismo de acompanhamento ou monitoramento de aluno a aluno acolhido em seu desempenho escolar?

f) Que mecanismos buscam ou querem desenvolver para que a permanência escolar seja melhor efetivada?

g) Não seria uma expectativa que as escolas que recebessem esses alunos tivessem um projeto político pedagógico voltado para as questões especificas deles?

h) A Vara de Infância acompanha, via relatónio, o aproveitamento escolar desses alunos? Não seria uma medida a ser adotada pela Secretaria de Educação a fim de que o acolhimento institucional seja mais bem sucedido no tocante à escolarização?

i) Não caberia a publicação pela SEDEST/SEDF de algumas orientações técnicas para facilitar o atendimento escolar de crianças e adolescentes matriculados em escola pública? Aqui não se trata do direito ao acesso, mas de preocupações com fatores ligados à permanência.

j) Há uma troca de dados SEDEST/SEDF que permita dizer quantos alunos estão matriculados na Educação Infantil, Ensino Fundamental e Ensino Médio e em que escolas de toda a rede?

1) Há uma troca que permita saber quais alunos obtiveram êxito em sua escolarização ano passado ou nos anteriores? 


\section{Anexo F - Formulário aplicado em entrevista à gestora distrital da Secretaria de Estado de Desenvolvimento Social e Transferência de Renda}

\section{ENTREVISTA COM A SECRETARIA DE ESTADO DE DESENVOLVIMINTO SOCIAL E TRANSFERENCIA DE RENDA DO DISTRITO FEDERAL - SEDEST}

a) Que demandas e de quais setores geraram a construção do GT Educação/Serviços de Acollimento entre a SEDEST e a SEDF?

b) A primeira iniciativa de encontro para viabilizar medidas conjuntas para os alunos acolhidos da Escola Pública partiu de qual Secretaria?

c) Quais eram as expectativas do setor frente aos primeiros encontros até formar o GT?

d) Qual o papel, a relevância e a aplicabilidade das políticas traçadas em nível federal (MDS) na gestão da Assistência Social no Distrito Federal, particularmente para grupos como os dos alunos acolhidos? $\mathrm{O}$ que ainda falta ser traçado em termos de políticas pelo governo federal?

e) Existe algum mecanismo de acompanhamento ou monitoramento de aluno a aluno acolhido em seu desempenho escolar por parte da SEDEST?

f) Que mecanismos buscam ou querem desenvolver para que a permanência escolar seja melhor efetivada?

g) Alunos com bolsa-escola são facilmente identificados por uma codificação específica, sempre atenta à frequência escolar dos mesmos. Por que o mesmo não pode acontecer com os acolhidos, que já perderam parte dos vínculos e se encontram com seus direitos severamente violados?

h) Consideram um problema não haver uma codificação dos alunos acolhidos por escola? Como avaliar e acompanhar a trajetória escolar de cada um sem codificá-los?

i) Não caberia a publicação conjunta entre SEDEST/ SEDF de algumas orientações técnicas para facilitar o atendimento escolar de crianças e adolescentes matriculados em escola pública? Aqui não se trata do direito ao acesso, mas de preocupações com fatores ligados à permanência.

j) Há uma troca que permita dizer quantos alunos estão matriculados na Educação Infantil, Ensino Fundamental e Ensino Médio e em que escolas de toda a rede?

1) Há uma troca de dados com a SEDEST/SEDF que permita saber quais alunos obtiveram êxito em sua escolarização ano passado ou nos anteriores? 


\section{Anexo G - Termo de Consentimento para profissionais da escola, do acolhimento, e para gestoras distritais da Assistência Social e Educação.}

\section{Termo de Consentimento Livre e Esclarecido}

Você está sendo convidado(a) a participar da entrevista semiestruturada, de responsabilidade da doutoranda ANETTE LOBATO MAIA, aluna do Programa de Pós-Graduação em Política Social da Universidade de Brasília. O objetivo desta pesquisa é verificar como escolas e unidades de acolhimento vêm atuando, naquilo que lhes cabe, na concretização do direito à educação de crianças e adolescentes sob medida protetiva de acolhimento institucional, fazendo parte, assim, da investigação que culminará na escrita da tese da referida aluna. Assim, gostaria de consultá-lo(a) sobre seu interesse e disponibilidade de cooperar com a pesquisa.

Você receberá todos os esclarecimentos necessários antes, durante e após a finalização da pesquisa, e lhe asseguro de que o seu nome não será divulgado, sendo mantido o mais rigoroso sigilo mediante a omissão total de informações que permitam identificá-lo(a). Os dados provenientes de sua participação na pesquisa, gravados ou escritos, ficarão sob a guarda do pesquisador responsável pela pesquisa, devidamente resguardados em código a fim de que seu nome não seja identificado.

A coleta de dados será realizada por meio de entrevistas semiestruturadas. É deste procedimento que você está sendo convidado a participar. Sua participação na pesquisa não implica nenhum risco.

Espera-se com esta pesquisa compreender como se configura nas unidades escolares o atendimento aos alunos que estão sob acolhimento institucional e as dificuldades e acertos nelas verificados no decorrer das tarefas docente e administrativo-pedagógicas.

Sua participação é voluntária e livre de qualquer remuneração ou benefício. Você é livre para recusarse a participar, retirar seu consentimento ou interromper sua participação a qualquer momento. A recusa em participar não acarretará qualquer penalidade ou perda de benefícios.

Se você tiver qualquer dúvida em relação à pesquisa, poderá me contatar através do telefone (61) 92166789 ou do email anettelm@globo.com.

Os resultados do estudo serão devolvidos aos participantes por meio de apresentação formal da defesa da tese e pela sua publicação em site da UnB, em seguida a esse evento.

Este documento foi elaborado em duas vias. Uma ficará com o(a) pesquisador(a) responsável pela pesquisa e a outra com o(a) senhor(a).

Brasília, de de 